\title{
NEW YORK STATE
}

ENERGY-ANALYTIC INFORMATION SYSTEM:

FIRST-STAGE IMPLEMENTATION

Jack Allentuck, OWen Carroll, linda Fiore, Neil Katz, Robert Malone, Robert nathans, Michael OWen, Drazen Prelec, ROBERt Raymond, ANn ReISMAN, and Harold ROSTOKER

September 1979

Prepared for the

NEW YORK STATE ENERGY OFFICE

by the

INSTITUTE FOR ENERGY RESEARCH

STATE UNIVERSITY OF NEW YORK

AT STONY BROOK

STONY BROOK, N.Y. 11790

and the

NATIONAL CENTER FOR ANALYSIS OF ENERGY SYSTEMS

DEPARTMENT OF ENERGY AND ENVIRONMENT

BROOKHAVEN NATIONAL LABORATORY UPTON, NEW YORK 11973

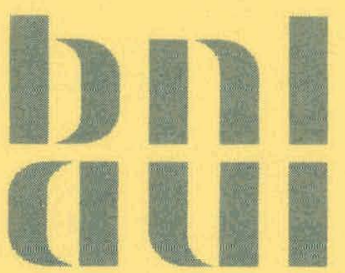




\section{DISCLAIMER}

This report was prepared as an account of work sponsored by an agency of the United States Government. Neither the United States Government nor any agency Thereof, nor any of their employees, makes any warranty, express or implied, or assumes any legal liability or responsibility for the accuracy, completeness, or usefulness of any information, apparatus, product, or process disclosed, or represents that its use would not infringe privately owned rights. Reference herein to any specific commercial product, process, or service by trade name, trademark, manufacturer, or otherwise does not necessarily constitute or imply its endorsement, recommendation, or favoring by the United States Government or any agency thereof. The views and opinions of authors expressed herein do not necessarily state or reflect those of the United States Government or any agency thereof. 


\section{DISCLAIMER}

Portions of this document may be illegible in electronic image products. Images are produced from the best available original document. 


\title{
NEW YORK STATE ENERGY-ANALYTIC INFORMATION SYSTEM: FIRST-STAGE IMPLEMENTATION
}

\author{
Jack Allentuck, Owen Carroll, linda Fiore, Neil katz, \\ Robert Malone, Robert Nathans, Michael OWen, Drazen Prelec, \\ Robert Raymond, Ann Reisman and Harold Rostoker

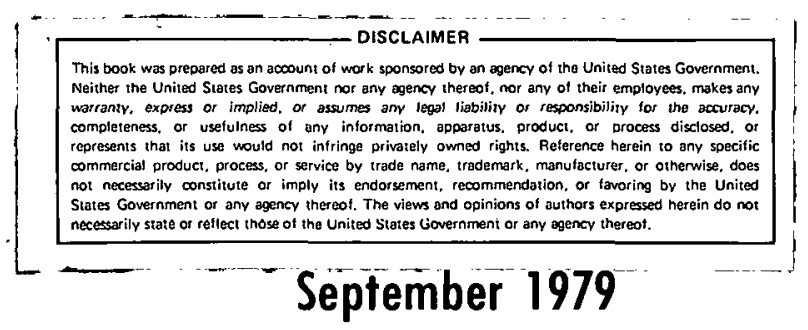

Prepared for the

NEW YORK STATE ENERGY OFFICE

POLICY ANALYSIS DIVISION NATIONAL CENTER FOR ANALYSIS OF ENERGY SYSTEMS BROOKHAVEN NATIONAL LABORATORY UPTON, N.Y. 11973
INSTITUTE FOR ENERGY RESEARCH

STATE UNIVERSITY OF NEW YORK

AT STONY BROOK

STONY BROOK, N.Y. 11790

\section{BROOKHAVEN NATIONAL LABORATORY}

\author{
ASSOCIATED. UNIVERSITIES, INC. \\ UNDER CONTRACT NO. DE-AC02-76CHO0016 WITH THE \\ UNITED STATES DEPARTMENT OF ENERGY
}




\section{DISCLAIMER}

This book was prepared as an account of work sponsored by an agency of the United States Government. Neither the United States Government nor any agency thereof, nor any of their employees, makes any warranty, express or implied, or assumes any legal liability or responsibility for the accuracy, completeness, or usefulness of any information, apparatus, product, or process disclosed, or represents that its use would not infringe privately owned rights. Reference herein to any specific commercial product, process, or service by'trade name, trademark, manufacturer, or otherwise, does not necessarily constitute or imply its endorsement, recommendation, or favoring by the United States Government or any agency thereof. The views and opinions of authors expressed herein do not necessarily state or reflect those of the United States Guvernment or anty agency thereor.

Printed in the United States of America

Available from

National Technical Information Service

U.S. Department of Commerce

5285 Port Royal Road

Springfield, VA 22161

Price: Printed Copy $\$ 10.75$; Microfiche $\$ 3.00$ 


\section{ABSTRACT}

So that energy policy by state government may be formulated within the constraints imposed by policy determined at the national level yet reflect the diverse interests of its citizens, large quantities of data and sophisticated analytic capabilities are required. This report presents the design of an energy information/analytic system for New York State, the data for a base year, 1976, and projections of these data.

At the county level 1976 energy-supply demand data and electric generating plant data are provided as well. Data base management is based on System 2000. Three computerized models provide the system's basic analytic capacity. The Brookhaven Energy System Network Simulator provides an integrating framework while a priceresponse model and a weather sensitive energy demand model furnished a short term energy response estimation capability. The operation of these computerized models is described in the report as well. 


\section{TABLE OF CONTENTS}

I. POLICY FORMULATION AND THE NYS ENERGY ANALYTIC INFORMATION SYSTEM.... 1

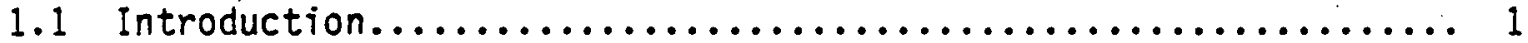

1.2 The New York Energy Situation in the National Context......... 2

1.3 Role of an Energy Information Analytic System (EIAS) in New

York State...................................... 9

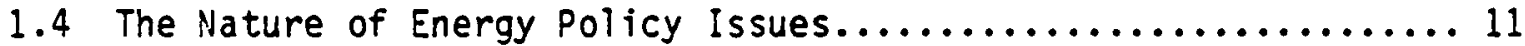

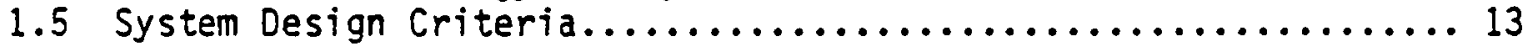

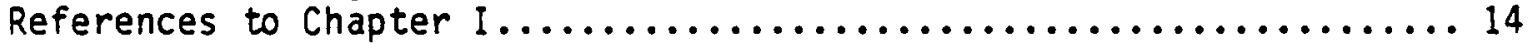

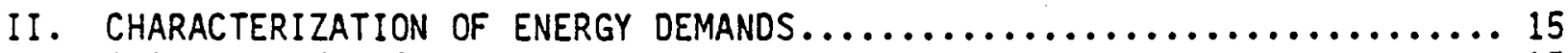

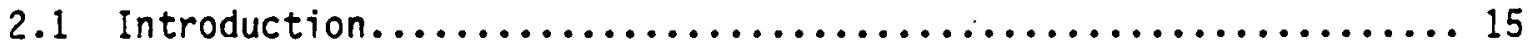

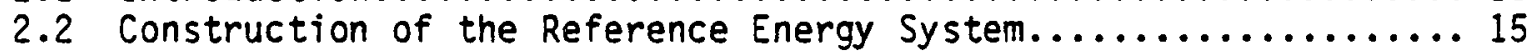

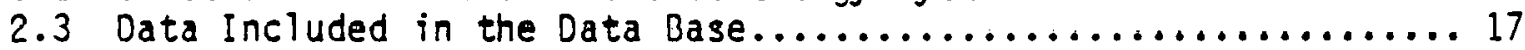

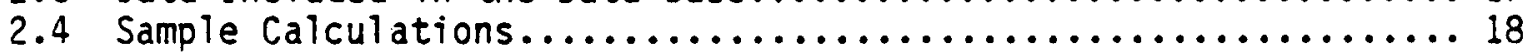

2.5 The ESNS Version of the New York State RES................. 19

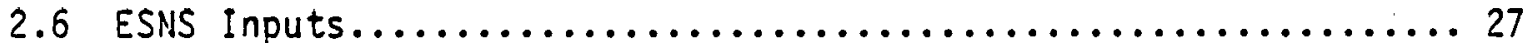

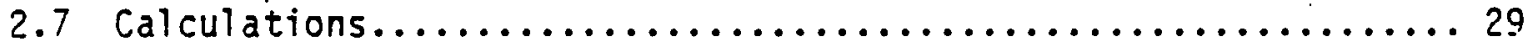

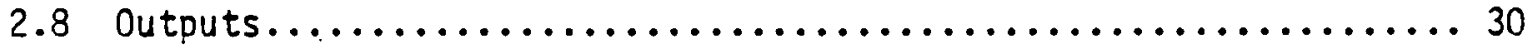

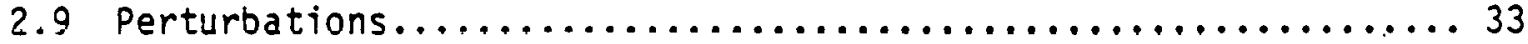

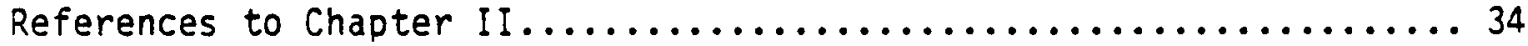

III. THE NATIONAL ENERGY PLAN AND THE NEW YORK STATE REFERENCE CASE...... 35

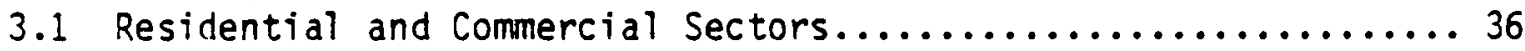

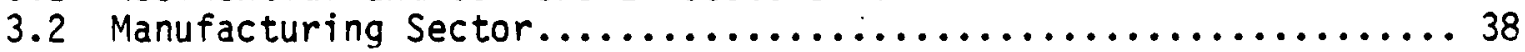

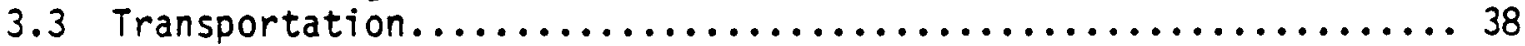

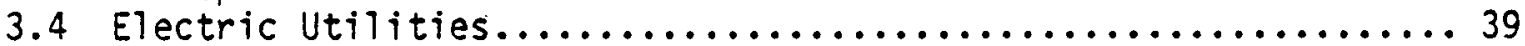

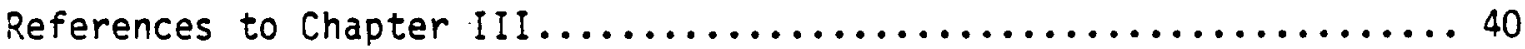

IV. NYS REFERENCE YEAR ENERGY DEMANDS $\ldots \ldots \ldots \ldots \ldots \ldots \ldots \ldots \ldots \ldots \ldots \ldots \ldots \ldots$

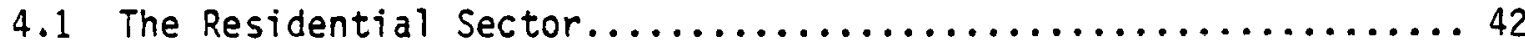

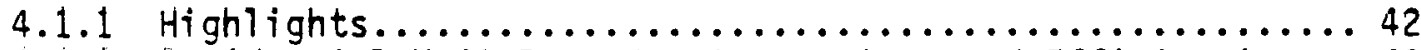

4.1.2 Residential Unit Demands, Saturation, and Efficiencles... 43

4.1.3 Residential Sector Projection Basis and Data Sources..... 45

4.1 .4 Residential Fuel Mix Projections.................. 45

4.1 .5 Housing Projections.......................... 46

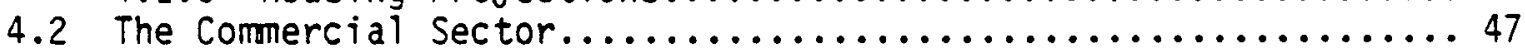

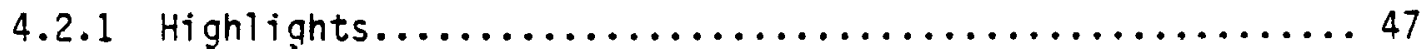

4.2.2 Comercial Sector Unit Demands, Saturation and

Efficiencies..............................448

4.2.3 Commercial Sector Projection Basis and Data Sources...... 49

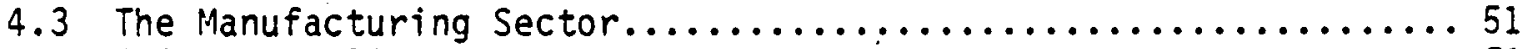

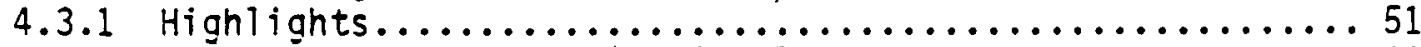

4.3.2 Industrial Sector Projection Basis and Data Sources...... 53

4.3.3 Industrial Fuel Mix Projections................... 53

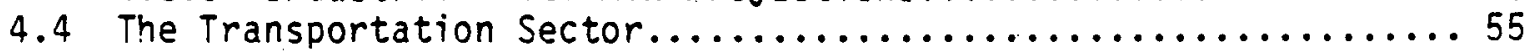

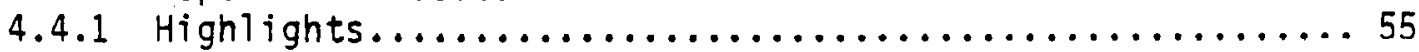

4.4.2 Transportation Sector Projection Basis and Data Sources.. 56

4.4.3 Transportation Fuel Projections.................. 56

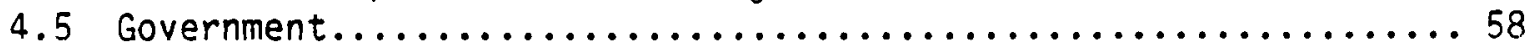

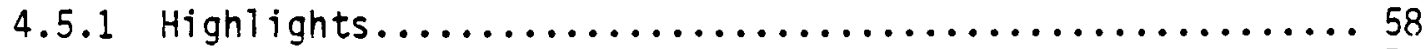

4.5.2 Government Projection Basis and Data Sources............. 59

4.5 .3 Government Fuel Mix Projections..................... 59 


\section{TABLE OF CONTENTS (continued)}

4.6 The Agricul tural Sector...............................60 60

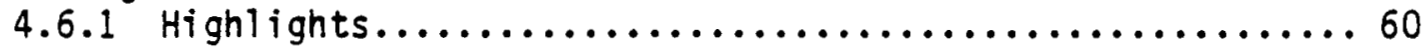

4.6.2 Agricultural Projection Basis, Data Sources and Fuel

Mix..........................................61

References to Chapter IV $\ldots \ldots \ldots \ldots \ldots \ldots \ldots \ldots \ldots \ldots \ldots \ldots \ldots \ldots \ldots, 62$

V. COUNTY LEVEL ENERGY SUPPLY AND DEMAND $, \ldots \ldots \ldots \ldots \ldots \ldots \ldots \ldots \ldots \ldots, \ldots \ldots$

5.1 Introduction.........................................65 65

5.2 Specific Structures....................................65

5.2 .1 Natural Gas.................................... 67

5.2 .2 Electricity...................................69 69

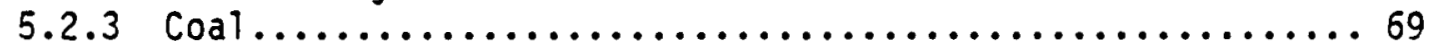

5.2 .4 Petroleum..................................... 71

5.2 .5 Solid Waste.................................... 72

5.3 County Level Supply and Demand........................... 72

5.3 .1 Natural Gas.................................... 72

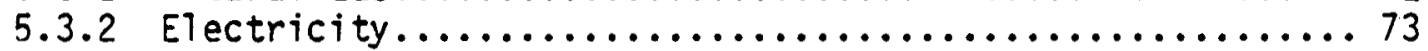

5.3 .3 Coal $\ldots \ldots \ldots \ldots \ldots \ldots \ldots \ldots \ldots \ldots \ldots \ldots \ldots \ldots \ldots \ldots \ldots \ldots, 73$

5.3 .4 Petroleum...................................... 79

5.3 .5 Solid Waste..................................... 80

References to Chapter $v \ldots \ldots \ldots \ldots \ldots \ldots \ldots \ldots \ldots \ldots \ldots \ldots \ldots \ldots, \ldots 2$

VI. SHORT RUN PRICE AND WEATHER MODELS $\ldots \ldots \ldots \ldots \ldots \ldots \ldots \ldots \ldots \ldots \ldots, \ldots 3$

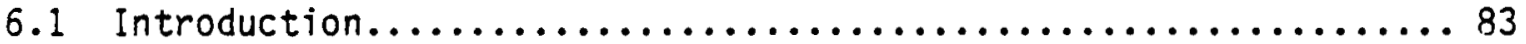

6.2 Short-Term Price Reșponse Model.......................... 83

6.2 .1 Industrial Sector............................. 84

6.2 .2 Residential and Commercial Sectors.................... 84

6.3 Weather Sensitive Energy Demand Model ....................... 86

6.3 .1 Residential Sector - Space Heat................... 86

6.3 .2 Residential Sector - Air Conditioning................ 88

6.3.3 Commercial Sector - Space Heat.................... 90

6.3.4 Commercial Sector - Air Conditioning................ 93

6.3 .5 Region Definition............................ 95

References to Chapter VI.................................... 96

VII. FURTHER DEVELOPMENTS $, \ldots \ldots \ldots \ldots \ldots \ldots \ldots \ldots \ldots \ldots \ldots \ldots \ldots \ldots, \ldots 7$

7.1 Introduction................................................ 97

7.2 Data Base Expansion................................... 97

7.3 Extensions of NYS EIAS Analytic Capabilities: Energy Facility

Siting........................................... 98

APPENDIX A. STATE AGgREGATE ENERGY DEMANDS...................... A-I

APPENDIX B. COUNTY LEVEL DATA BASE......................... $8-1$

APPENDIX C. COMPUTER OPERATIONS............................ C-I 


\section{LIST OF TABLES}

$\frac{\text { Table }}{1}$

U.S. Energy Consumption in $1976 \ldots \ldots \ldots \ldots \ldots \ldots \ldots \ldots \ldots \ldots$ Representative 1976 Energy Prices in New York State.......... 4 Optional Parameters for NYS-ESNS............................. Efficiencies: Commercial/Residential Sector.............. 37 NYS Market Penetrations of New Technologies Residential/

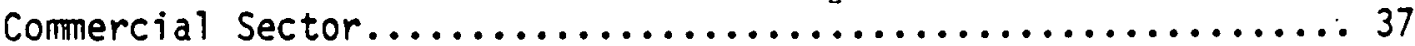

NYS Changes in Electric Energy Market Share................ 37

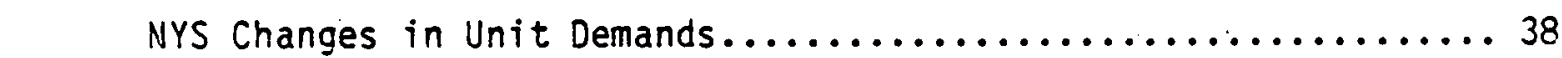

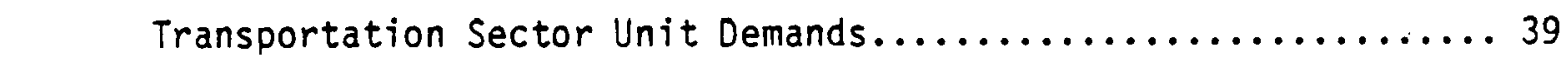

Composition of Energy Input to US and NYS Electric Generation... 39 NYS Household and Population Projection................ 46 Annual Growth Rates and Basis Changes for Reference Years...... 46

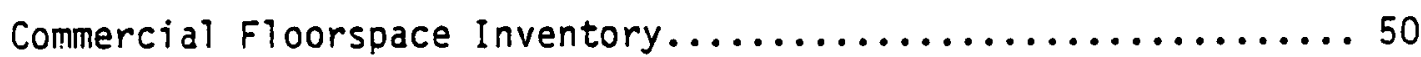
Industrial Subsectors Ordered by 1976 Energy Consumption....... 54 Major Industrial Energy Users: Total Fuel Demand........... 54 Industriạ! Energy Demand by Fuel Type................... 54 Annual Growth Rates and Basis Changes for Reference Years...... 57

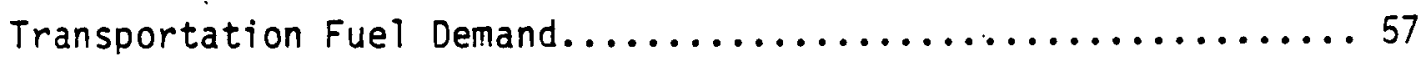
Summary of Transportation Energy Demands................ 57 Annual Growth Rates and Basis Changes for Reference Years...... 59 Summary of Energy Use in the Agriculture Sector.............60 Major Gas Utilities in N.Y. and Supply Types............. 74

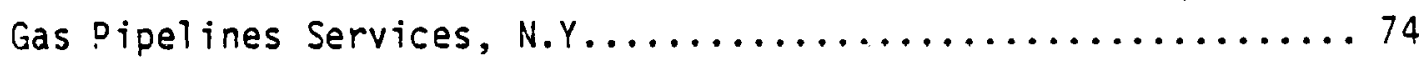
Counties Serviced by Major Gas lltilities, New York State.......75 Counties Served by Electric Utilities................ 77 Coal Utility Regions in N.Y....................... 80 


\section{LIST OF TABLES (continued)}

$\frac{\text { Table }}{27}$

Energy Intensity Factors-Residential Sector - Space Heat....... 87

Fuel Efficiencies-Residential Sector, Space Heat............ 88

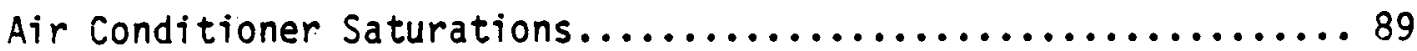

Energy. Intensity Factors-Air Conditioning End-Use. Fuel Efficiencies - Residential Sector - Air Conditioning...... 90

Energy Intensity Factors - Comercial Sector - Space Heat....... 92

Fuel Efficiencies - Commercial Sector - Space Heat............ 92

Air Conditioning Saturations - Commercial Sector............. 93

Energy Intensity Factors - Commercial Sector - Air

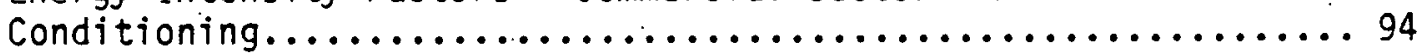
Fuel Efficiencies - Commercial Sector - Air Conditioning....... 94 
$\frac{\text { Figure }}{1}$

US Reference Energy System, 1976

NYS Reference Energy System, $1976 \ldots \ldots \ldots \ldots \ldots \ldots \ldots \ldots \ldots \ldots$

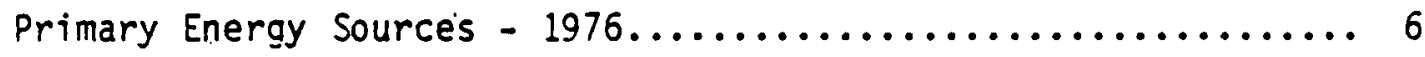

Per Capital Energy Consumption - 1976.................... 7

Schema of Role of the New York Energy Information/Analytic

System............................................ 10

New York State Energy Policy Issue Matrix $\ldots \ldots \ldots \ldots \ldots \ldots . . . .12$

NYS-ESNS Networks

NYS-ESNS Energy System Supply Process Network (Nuclear, Hydroel ectric, Geothermal )........................... 20 NYS-ESNS Energy System Supply Process Network (Pumped

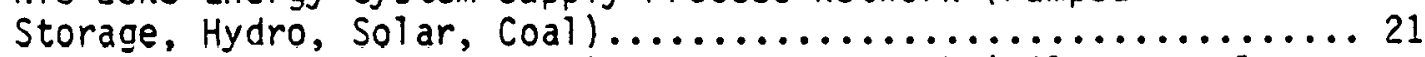
NYS-ESNS Energy System Supply Process Network (0i1, Natural

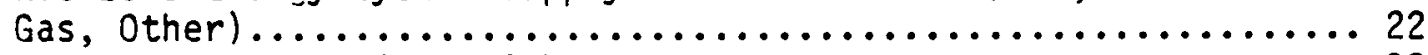

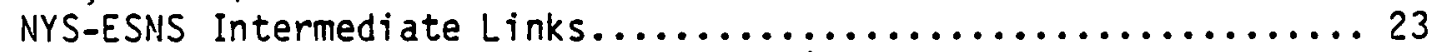
NYS-ESNS Utilization Process Network (Residential Water Heat \& Cooking; Industrial Process Heat, Misc., Petrochemicals)....... 24 NYS-ESNS Utilization Process Network (Residential Lighting, Appliances, Space Heat, Air Conditioning; Commercial \& Industrial Misc. Electric; Transportation, Electrified Mass Transit)........................................... 25 NYS-ESNS Utilization Process Network (Commercial Air

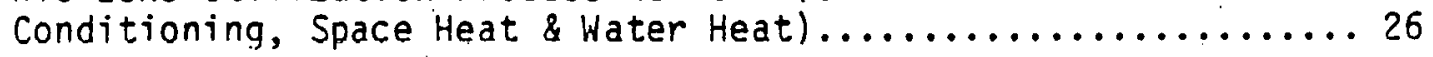

Energy Balance for Process............................ 28

Energy Demand by Sector............................. 41

NYS Residential Sector Energy Demand.................... 44

NYS Commercial Sector Energy Demands.................... 49

NYS Manufacturing Sector Energy Demands................. 52

County Data Base Structural Elements................... 66

Tree Structure for New York State County Data Base........... 66

Structure for Natural Gas......................... 68

Structure for Electricity......................... 70

Structure for Coar................................ 70

Structure for Petroleum............................. 71 
POLICY FORMULATION AND THE NYS ENERGY INFORMATION SYSTEM

\subsection{INTRODUCTION}

The urgent need for a national energy plan has been evident since the early 1970's. The inability of the Executive and the Conoress to reach a consensus reflects the conflicting interests of diverse constituencies, some regional and others, cutting across geographical regions, deriving from common economic interests, environmental attitudes and social viewpoints.

The effects at the state government level of the continuing controversy as to the shape of a national energy policy are twofold. On the one hand state government must assure that the interests of the people of the state are reflected in the details of national energy policy as it develops. On the other hand, it must, within the limits of its authority, formulate and implement state energy policy not only with the enhancement of the welfare of its citizens as a goal but also with a view to its compatability with emerging national energy policy.

The complexities of policy formulation within such constraints cannot be overstated. This is especially true when one considers that interests of individuals and groups within the state reflect to a greater or lesser degree those that exist at the national level.

As at the national level, there are regional differences within the state. Serious policy making on energy at the state level must therefore be informed by vast quantities of data in sufficient detail to assess not only the consequences of policy for the state as a whole but its likely effects on various regions and interest groups within the state. In addition to data, an analytic capability must be available to provide objective indications of the likely impact of energy policy on the state as a whole as well as on regions 'within the state. In the sections of this chapter which follow, we present first an overview of New York's energy situation within the national context. This is followed by a brief description of the energy issues confronting the state. Here we will underscore the several levels at which energy policy must be considered. In a subsequent section we shall review the evolution of the New York State Energy Information Analytic System (NYS EIAS)l as a tool for energy policy formulation. 


\subsection{THE NEW YORK ENERGY SITUATION IN THE NATIONAL CONTEXT}

The essential structure of the current U.S. energy situation is portrayed in Figure 1.* On the right-hand side of the figure are indicated the final uses of energy and the amounts of energy (in $10^{15}$ or quadrillion Btu) going to each use in 1976. The numbers in parentheses in the figures refer to the

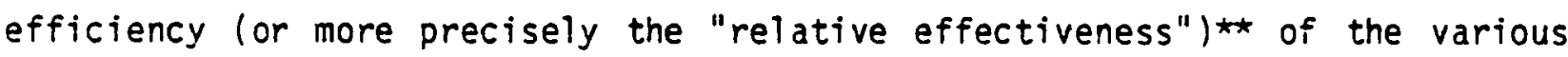
processes of energy conversion incorporated in the system. In tracing back (to the left in the figure) one gets to the amount of primary resources required to supply the demand for energy with the current system.

Tahle 1 presents a summary of the data of the figure. Here the amount of each fuel used by each consuming sector is indicated. Note that plertririty (at $3413 \mathrm{Btu} / \mathrm{KWh}$ ) is included as a "fuel" under each sector. Fuels going to produce electricity are indicated in the "Utility" column. The total resource consumption indicated in Table 1 is lower than that indicated in Figure 1 because it is measured at the point of consumption. Taking all system inefficiencies into account the total resource consumption in 1976 was $73.98 \times 10^{15}$ Btu.

\section{Table 1}

U.S. ENERGY CONSUMPTION IN 1976

$\left(\right.$ Rt.1 $\left.\times 10^{15}\right)$

\begin{tabular}{|c|c|c|c|c|c|c|}
\hline Electricit) & $\frac{\text { Resid. }}{2.02}$ & $\frac{\text { Comm. }}{1.42}$ & $\frac{\text { Ind. }}{2.46}$ & $\frac{\text { Trans. }}{.02}$ & $\frac{\text { Utility }}{-}$ & $\frac{\text { Total }}{5.92^{\star}}$ \\
\hline Petroleum Products & 2.94 & 1.75 & 5.30 & 17.70 & 3.15 & 30.84 \\
\hline Natural Gas & 5.24 & 2.14 & 6.84 & - & 3.14 & 17.36 \\
\hline al & - & 0.12 & 3.75 & 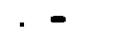 & 8.93 & 12.80 \\
\hline Nuclear & - & - & . & - & 1.89 & 1.89 \\
\hline dro & 6 & $\bar{z}$ & - & - & 3.20 & 3.20 \\
\hline Total & 10.20 & 5.43 & 18.35 & 17.72 & 20.31 & $66.09^{\pi}$ \\
\hline
\end{tabular}

\#ETectricity not included in column total to avoid double counting. Fuels used to produce electricity are shown under column labeled "Utility."

*The BNL Reference Energy System (RES) is fully described in Chapter II. $\star \star$ This term is defined on page 15 . 


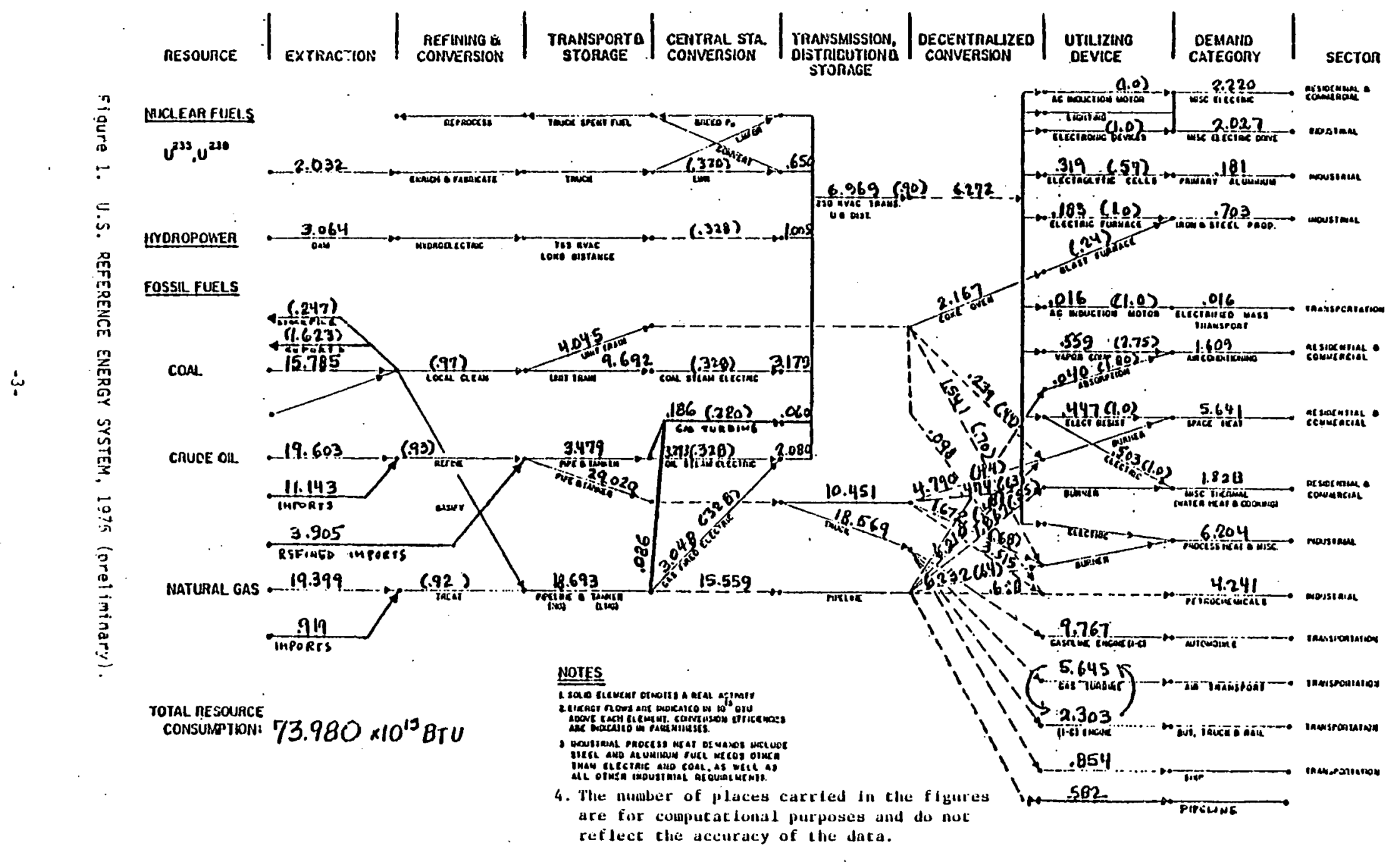


In Figure 2 we display a similar representation of the 1976 eneray situation for New York State. Some comparisons between the U.S. and New York situations are noteworthy. In Figure 3 we present a summary of primary energy resources used in 1976 in the U.S. and New York State. The much greater proportion of oil consumed in New York State when compared to the nation as a whole is striking as is the opposite relationship for natural gas. Interesting as well, is the relatively small proportion of coal used in New York State when compared to national use.

Turning to the demand side, in Figure 4 we display a comparison between New York State and the United States of 1976 energy demand per capita in several final demand sectors. Of note are the significantly smaller per capita energy. demands in New York's manufacturing and transportation sectors when compared to the national picture. In the manufacturing sector this reflects the passing of New York to a post-industrial society with increasing emphasis on services rather than manufacturing. In the transportation sector lower per capita energy consumption is a consequence of New York City's highty developed mass transit system.

Finally in our brief survey of New York's energy situation in the national context we present in Table 2 a comparison of energy prices in New York with national average prices.

Table 2

REPRESENTATIVE 1976 ENERGY PRICES IN NEW. YORK STATE

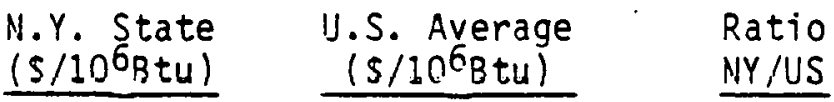

Electricity - Residential New York City Buffalo

$\left(s / 10^{6}\right.$ Btu)

New York City

Buffalo

23.7

10.8

15.3

1.79

3.02

1.95

$0 i 1$ - Residential New York City Buffalo

3.05

3.06

2.08

2.29

1.76

1.16

2.19

1.42

$0 i 1$ to Utilities

Con Edison Niagara-Mohawk

Coal to Utilities

Rochester Gas and Electric

1.35

2.88

1.69

1.09

N.Y. State Elec. and Gas

$0.85 \quad 1.36$




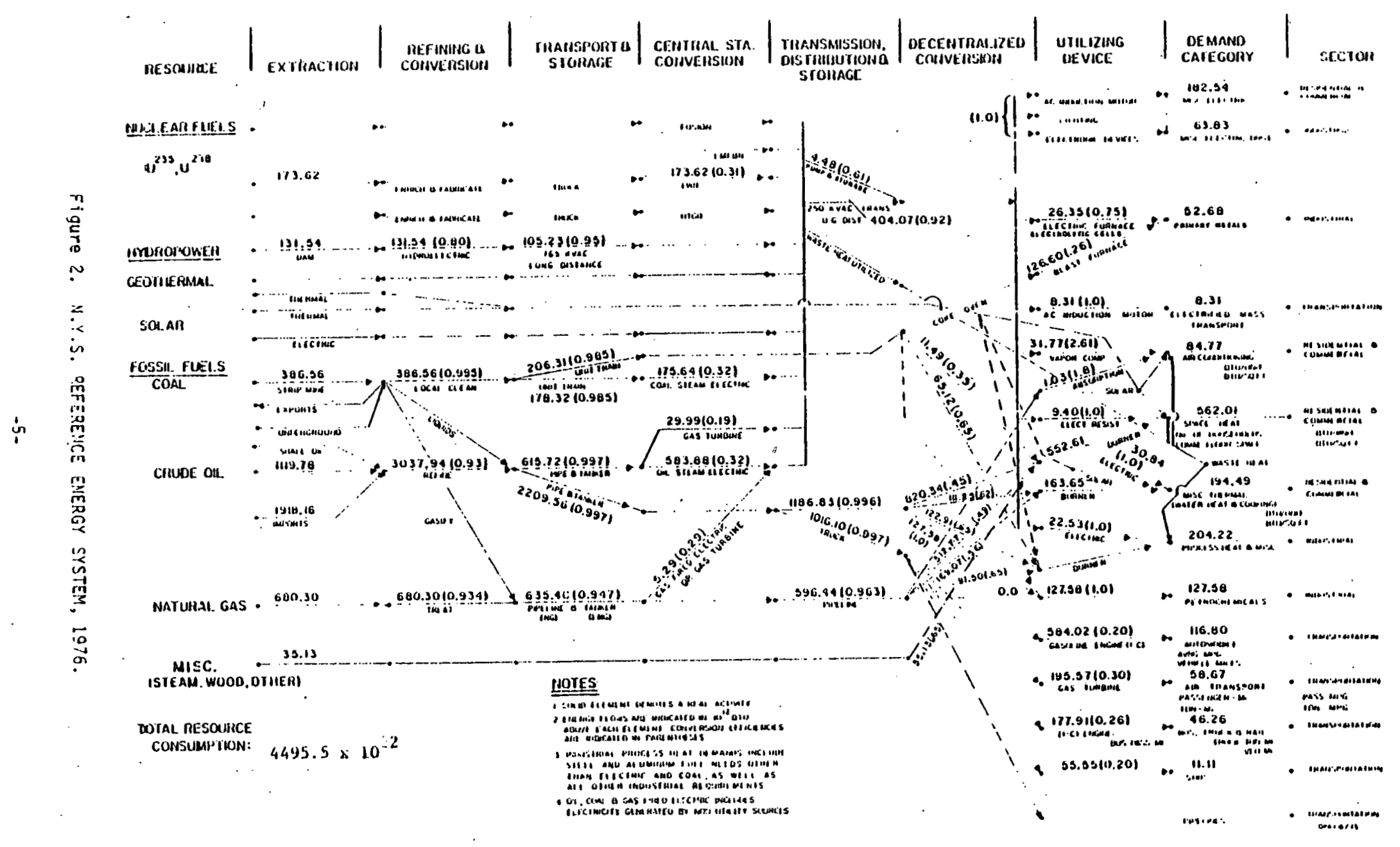




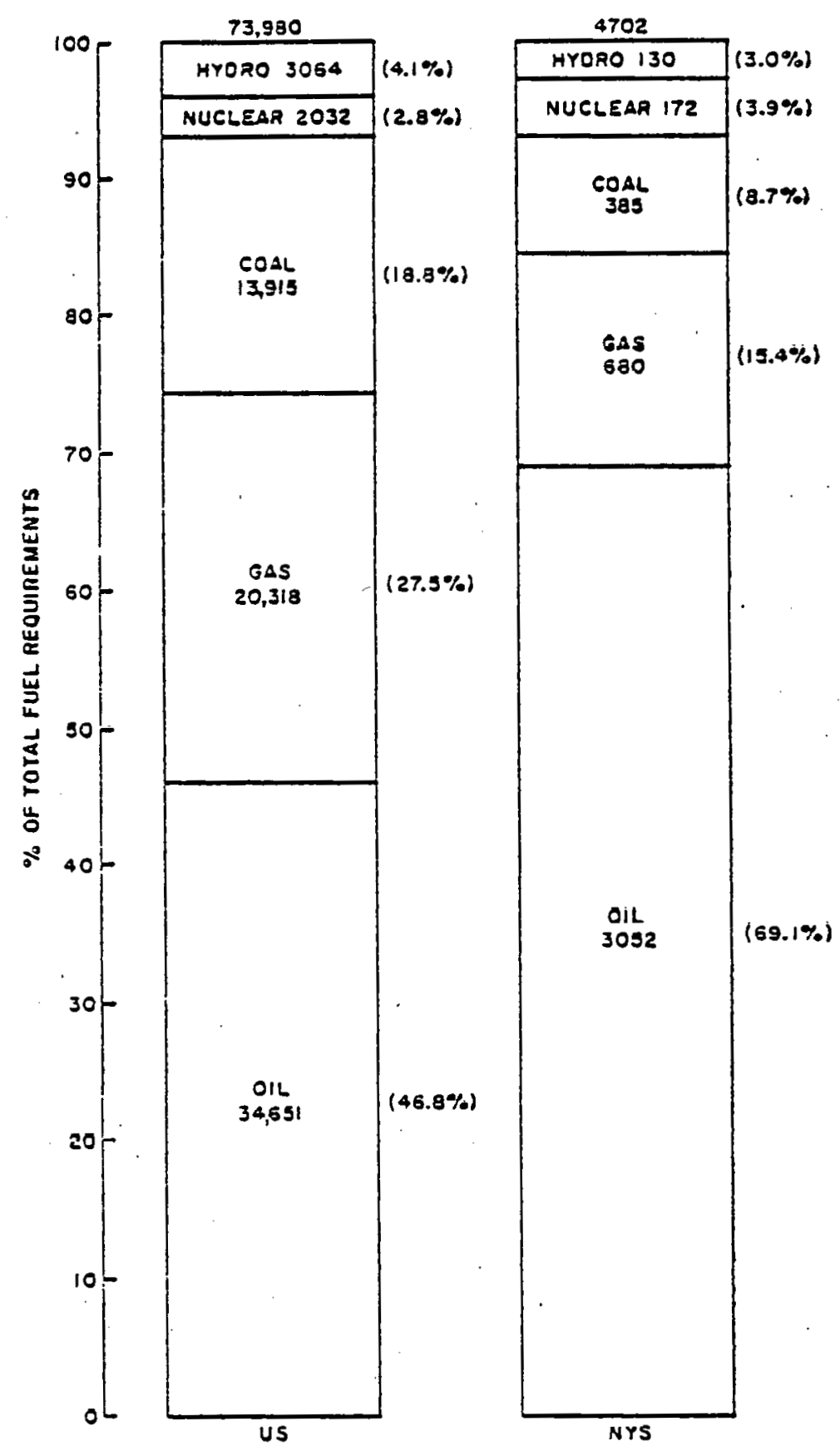

Figure 3. PRIMARY ENERGY SOURCES - 1976 (Btu $\times 10^{12}$ ). 

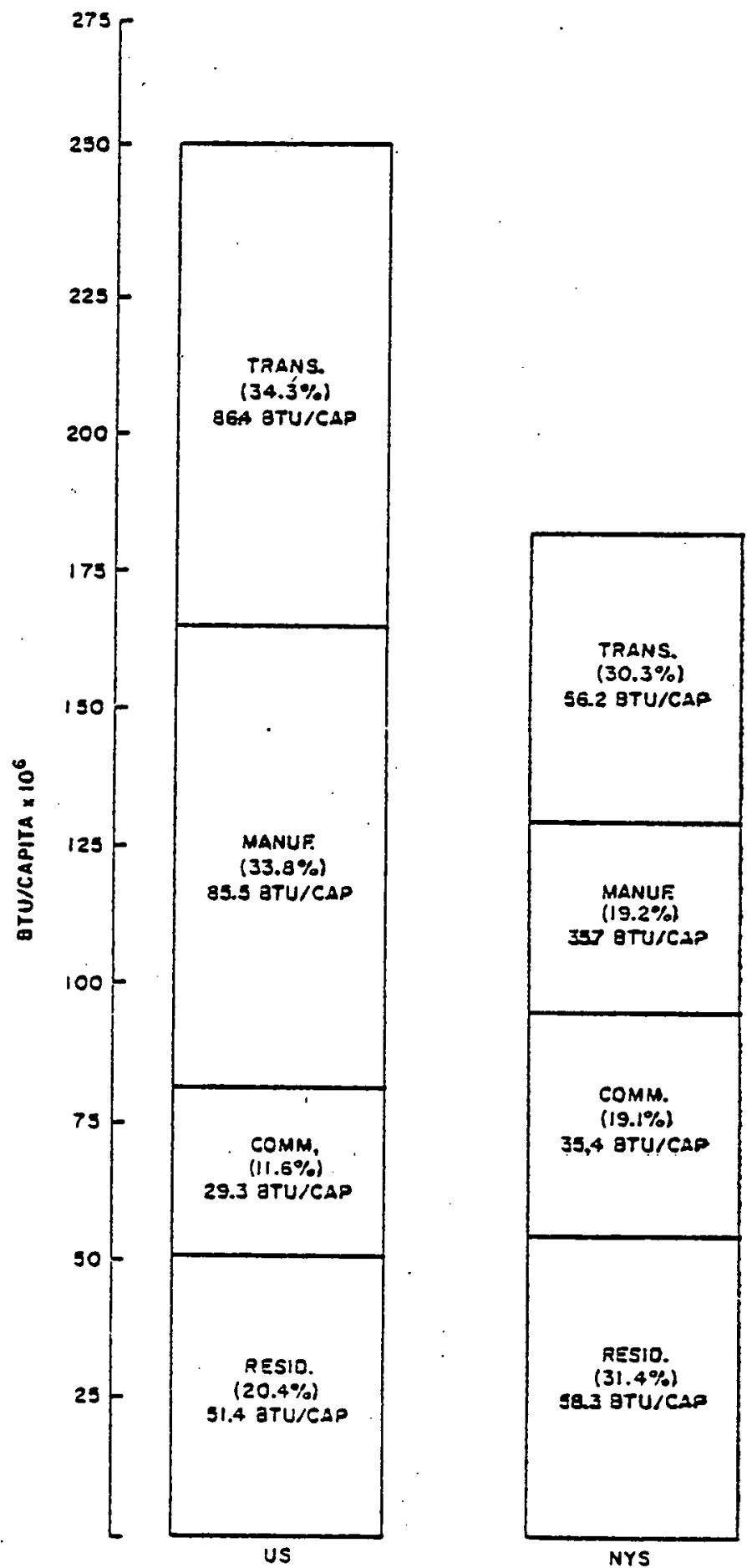

Figure 4. PER CAPITA ENERGY CONSUMPTION - 1976. 
The comparisons presented above underscore some of the basic considerations which engage the attention of New York energy planners. These considerations and others are summarized below:

- To a larger extent than many states in other sections of the country, New York's energy supplies are derived from oil and gas fuels for which the uncertainty in future supply and price is greatest. As shown in Figure 2, in 197669 percent of New York's total primary energy supply was derived from $0 i 1$ and 15 percent from natural gas. For the United States as a whole these statistics were 47 percent and 28 percent, respectively.

- Coal played a much smaller role in supplying the energy needs of New York than for the entire nation. New York derived only $8.7 \%$ of its energy needs from coal while for the United States this figure was $18.8 \%$.

- Energy demands per capita of the manufacturing and transportation sectors in New York State were substantially smaller than in the United States as a whole. For the former these figures were 35.7 Btu/capita and 56.2 Btu/capita respectively, for the latter 85.5 Btu/capita and 86.4 Btu/capita.

0 . Virtually all of the oil and gas used by the state is imported, with $64 \%$ of the oil coming from foreign sources. 2 The state is thus vulnerable to supply disruptions both domestically and internationally. Unless prescribed by Federal legislation, the energy producing regions of the country furthermore can be expected to use their energy resources to capture related manufacturing activity away from those states which import fuels.

- Eneray prices in the Northeast, and in New York in particular, tend to be higher in general than most other regions of the country. 3 This is particulariy true of electricity prices. In some of the most populated parts of the state these were more than $100 \%$ higher than the national average. This is due in part to the mix of fuels used to produce electricity and in part to the prices of those fuels. These factors add to other elements in the state such as higher labor costs to reduce the state's relative economic competitiveness. 


\subsection{ROLE OF AN ENERGY INFORMATION ANALYTIC SYSTEM (EIAS) IN NEW YORK STATE*}

In the previous section we outlined briefly the considerations facing New York energy planners. In this section we examine the role of the NYS EIAS in policy formulation.

We have already discussed the state energy planner's need to consider not only the welfare of the state as a whole but also the needs of separate constituencies, some based on common regional interest, and others founded on economic motivations.

An EIAS has two parallel roles in support of energy pianning, policy analysis and policy implementation in the state. In the first. instance it is an assembly of current energy data providing timely information on energy supplies and demands in the state as a whole and to political or regional subdivisions at a reasonable level of disaggregation. In the second instance it provides an analytic capability which enables the assessment of the effect of policy on the state's energy supply/demand situation. Since policy planning and implementation is undertaken in the context of a future year an analytic capability of the type required must be based on a view of the future as it is expected to exist absent perturbations arising from policy changes.

It must however be understood that data banks and computer programs do not solve energy problems. They do provide important information and a set of tools that can be used by analysts to examine the implications of alternative energy decisions. Thus, in designing the New York Energy Information/Analytic System one must start with a conception of how such a system fits into the decision making process of government.

The relationship between the system and its users is indicated in figure 5. The basic conception is that the Information/Analytic System, and the assessments performed by the analysts that are using the system, are objective and politically neutral. Issues or questions are formulated by the users or by the staff of the analytical group. In some cases there will be a relatively simple flow of information from the system to the questioner (in response, for example, to the question, "how much oil was consumed for space heating in single family dwellings in 1976"). In other cases, and the more important ones, an assessment will have to be performed. In general the

*Much of the material in this chapter appeared oreviously in Reference 1. 
intent of that assessment will be to analyze the impacts of altemative policies. For example, alternative incentive systems for homeowners to install solar heating systems would be compared in terms of the direct cost to the state (say in reduced tax revenues), effects on industrial and commercial activity, effects on employment, and impact on the state's environment. The analysis may incorporate information that is not part of the system (such as experience in other states with similar policies).

The analysis then supplies the decisionmaker with a set of evaluated options regarding the policy in question. Even in the simple example chosen, the analysis may not be able to identify the "best" policy, for that requires a comparison between very different criteria. The trade-off between environment and jobs, for example, is a politteal decision. Furthermore, there may be non-technical considerations that enter the decision making process. For the solar incentive case, for example, the existence of an active public interest group supporting solar energy might enhance the feasibility of certain types of incentives.

As shown in Figure 5, issues may be formulated by the users of the system or they may be formulated by the analytical group. The analytical group, or an office to which it is attached, may also be given the responsibility of preparing on a regular basis reports on aspects of energy in the state.

The point to be emphasized in this discussion is that in all of these modes of operation the system can be operated in an objective, non-political manner. Policy analysis can be distinguished from policy maxing and the effectiveness of an Energy Information and Analytic System will be significantly increased if that distinction is maintained in its design and implementation.

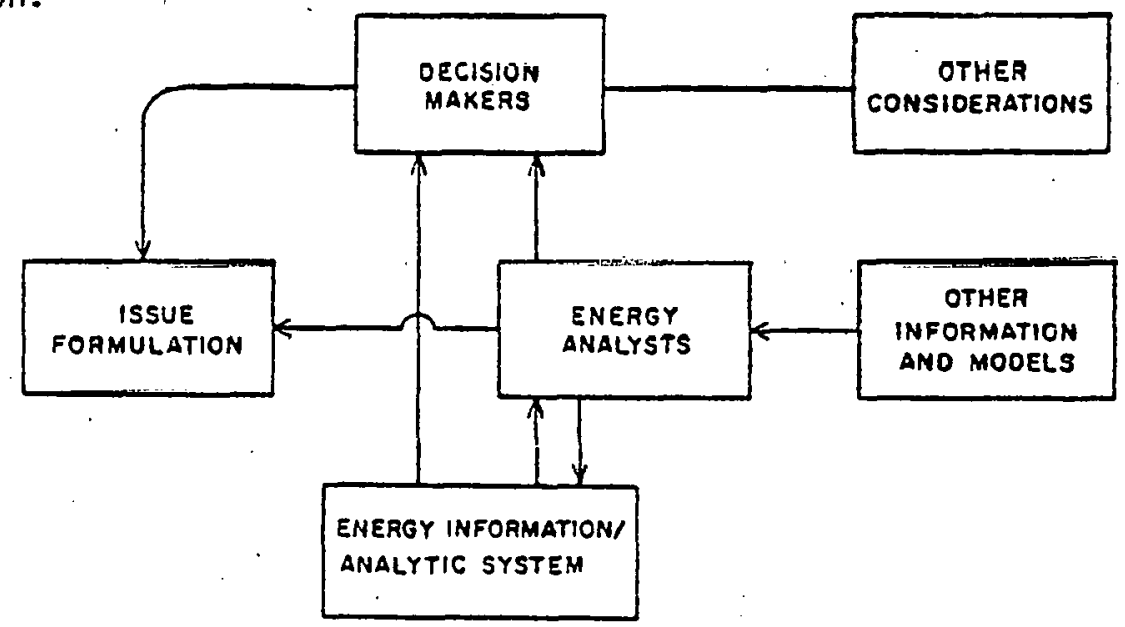

Figure 5. SCHEMA OF ROLE OF THE NEN YORK ENERGY INFORMATION/ANALYTIC SYSTEM. 


\subsection{THE NATURE OF ENERGY POLICY ISSUES}

The design of a New York EIAS is based on the issues that the system must address and the criteria used to evaluate those issues. Some representative issues or questions that the system might be required to address are:

1. What would be the effect on the state of alternative federal policies on natural gas price regulation?

2. Should the state encourage natural gas production from Lake Erie and if so under what conditions?

3. Under conditions of another oil embargo what petroleum product allocation scheme produces least impact on the overall state wel fare?

4. What would be the effect on the state of a moratorium on the construction of new nuclear power plants?

5. What would be the effect on energy costs and availability within the state of proposed changes in federal environmental regulations (such as ammendments to the Clean Air Act)?

6. What are the most important areas for the state to invest in energy research and development?

7. What effect would mandatory lighting efficiency standards for public buildings have on projected 1985 energy consumption?

8. What would be the effect of al ternative residential and commerical building codes?

9. What regions of the state would be most affected by natural gas curtailments?

10. What benefits and costs would accrue to the state from investment in a] ternatives to automotive transport?

11. What are the possibilities for, the impacts of, and barriers to increased coal use in the state?

12. What is the potential for combined waste-coal fluidized bed boilers in New York City?

13. What effect would an LNG terminal in New York harbor have on the availability and cost of natural gas to the state?

14. What effect would development of Atiantic Outer Continental Shelf (OCS) gas and oil resources have. on state supplies? What Federal and state regulations regarding OCS development are of most benefit to the state? 
These issues are broadly representative of the types of questions that the system may be called upon to address. Some of the issues are fairly narrow and relatively easily dealt with. Others, to be properly addressed, require extensive in-depth analysis. Question No. 6, for example, is the basis for determining the program of the Energy Research and Development Authority. Answering that simple question requires careful and extensive analysis, drawing on a wide range of expertise and is central to the planning function of the Authority. The analysis of issue No. 7 is one element of a state energy conservation plan as called for if the state is to receive federal funding under the State Energy Conservation Program administered by the Department of Energy.

The range of issues and the basic concerns to be dealt. with can be represented schematicaliy as in Figure 6 . This scheme is based on the observation that New York's energy situation derives from its geographic and other relationship to the country as a whole, while communities, businesses and individuals experience varying effects depending on their spatial location within the state. It also reflects three basic analytic concerns: effects on energy supply-demand, economic activity, and environmental quality. These categories define the structure into which energy policy issues fall and through wich they must be analyzed.

\begin{tabular}{|c|c|c|c|}
\hline \multirow[b]{2}{*}{ EFFEGT FOCUS } & \multicolumn{3}{|c|}{ GEOGRAPHICAL FOCUIS } \\
\hline & $\begin{array}{l}\text { US/NY } \\
\text { STATE RELATIONS }\end{array}$ & $\begin{array}{c}\text { NEW YORK S TATE } \\
\text { AS AN ENTITY }\end{array}$ & $\begin{array}{l}\text { REGIONS WITHIN } \\
\text { NEW YORK STATE }\end{array}$ \\
\hline $\begin{array}{l}\text { ENERGY } \\
\text { SUPPLY/OEMANO }\end{array}$ & & & \\
\hline $\begin{array}{l}\text { ECONOMIC } \\
\text { ACTIVITY } \\
\text { ANO HELFARE }\end{array}$ & - & & \\
\hline $\begin{array}{l}\text { ENVIRONMENTAL } \\
\text { OUALITY }\end{array}$ & & & . \\
\hline
\end{tabular}

Figure 6. NEW YORK STATE ENERGY POLICY ISSUE MATRIX. 


\subsection{SYSTEM DESIGN CRITERIA}

In designing an Energy Information/Analytic System to deal effectively with the issues discussed above, certain basic criteria must be considered:

1. Responsiveness: the system must be able to respond quickly to the needs of various parties in the state who are responsible for energy related decisions.

2. Inclusiveness: the system must be able to deal in adeauate depth with the wide range of issues and effects that are of potential concern.

3. Cost: the system should be implemented at lowest possible cost to the state.

Since these simple criteria are almost mutually exclusive, the design and implementation of the system must consider the best means of accommodating them.

Obviously not all energy policy issues are of equal concern at any one time. In fact, the focus of energy planning is continually changing. Newspaper headlines in the past few years have declared a succession of crises; gasoline shortages, electricity prices, natural gas supplies, offshore oil development, energy conservation, and nuclear power have succeeded each other in the public and political consciousness. Clearly, an Energy Information/Analytic System must be able to respond quickly to supply reliable analyses on a wide variety of issues as they become politically important. In order to accomplish that, however, data and analytical techniques must be constructed in anticipation of future issues of concern and not in response to current issues. At the same time, it would be impractical to invest large amounts of time and funds into the construction of a completely general and universal system that would only be available after some considerable length of time and then probably be incapable of answering some previously unanticipated question. The sensible approach to the development of the system would thus be to put together the most important basic information and analytic tools and then to introduce further information and methods are required to address central continuing policy issues. This implies that the system must be designed to accept, digest, and utilize new information with ease. It implies a dynamically growing, increasingly effective system. In a subsequent section we examine the way in which the system may be fuller developed to satisfy the needs of energy planners. 
REFERENCES TO CHAPTER I

1. J. Allentuck, et. al., "An Energy Information and Analytic System for New York State," Draft Final Report (August 1976) Brookhaven National Laboratory, Upton, New York.

2. About $5.0 \times 1012$ Btu of oil were produced in the state in 1975 , corresponding to less than $0.2 \%$ of consumption. Gas production $(6.8 \times$ 1012 Btu corresponded to about $1 \%$ of consumption.

3. Although some natural gas prices have been maintained relatively low (somewhat of an anomaly in the Northeast), policies to normalize interstate and intrastate gas rates promise to eliminate that advantage in the future oil prices under current regulatory policies have little inter regional variation.

4. J. Allentuck, et. al., "An Assessment of. Energy Research Development and Demonstration Priorities for New York State," BNL-50735 (November 1977), Brookhaven National Laboratory, Upton, New York.

$-14-$ 
CHAPTER II

\section{CHARACTERIZATION OF ENERGY DEMANOS}

\subsection{INTRODUCTION}

The Brookhaven Reference Energy System (RES) 1 is a convenient way of representing the energy system of a state. Figure 2 is the New York 1976 RES and is included again in this chapter for ease of reference. This system, and the detailed technological, economic, and environmental assumptions which comprise the supporting data base, have been developed to program the kind of technology and policy assessment required by numerous studies which BNL has undertaken for the U.S. Department of Energy as well as the 1977 study for NYS Energy Research and Development Authority (NYS ERDA).2 It forms the principal analytic component of the NYSEIAS in the form of its computerized version, the ESilS Model. 3 In the paragraphs which follow we describe the construction and use of the RES while in a subsequent section we discuss ESNS. In Chapter VI we examine a short term price response model of energy demand and a model for determining the effects of temperature variations on NYS energy demand.

\subsection{CONSTRUCTION OF THE REFERENCE ENERGY SYSTEM}

The format for the Reference Eneray System (RES) is a network diagram which indicates energy flows and associated conversion efficiencies, along with the reference technologies used to accomplish the energy conversion. The system indicates the reference conversion processes used in the following activities, where each applies to a specific energy resource or form.

1. Extraction

2. Refining and/or conversion

3. Transport of primary energy source

4. Centralized conversion (e.g., electricity generation)

5. Transport or transmission and storage of secondary eneroy form

6. Decentralized conversion

7. Utilization in an end use device

A single path through the network reflects the application of a specific energy resource to a given demand category. Alternate paths and branches reflect the amount of substitutability that is feasible among different resources. Demand figures are exogeneously estimated for each reference year.

Associated with each energy flow or link in the RES are two sets of coefficients: efficiency and environmental. The RES's developed for visual dis- 


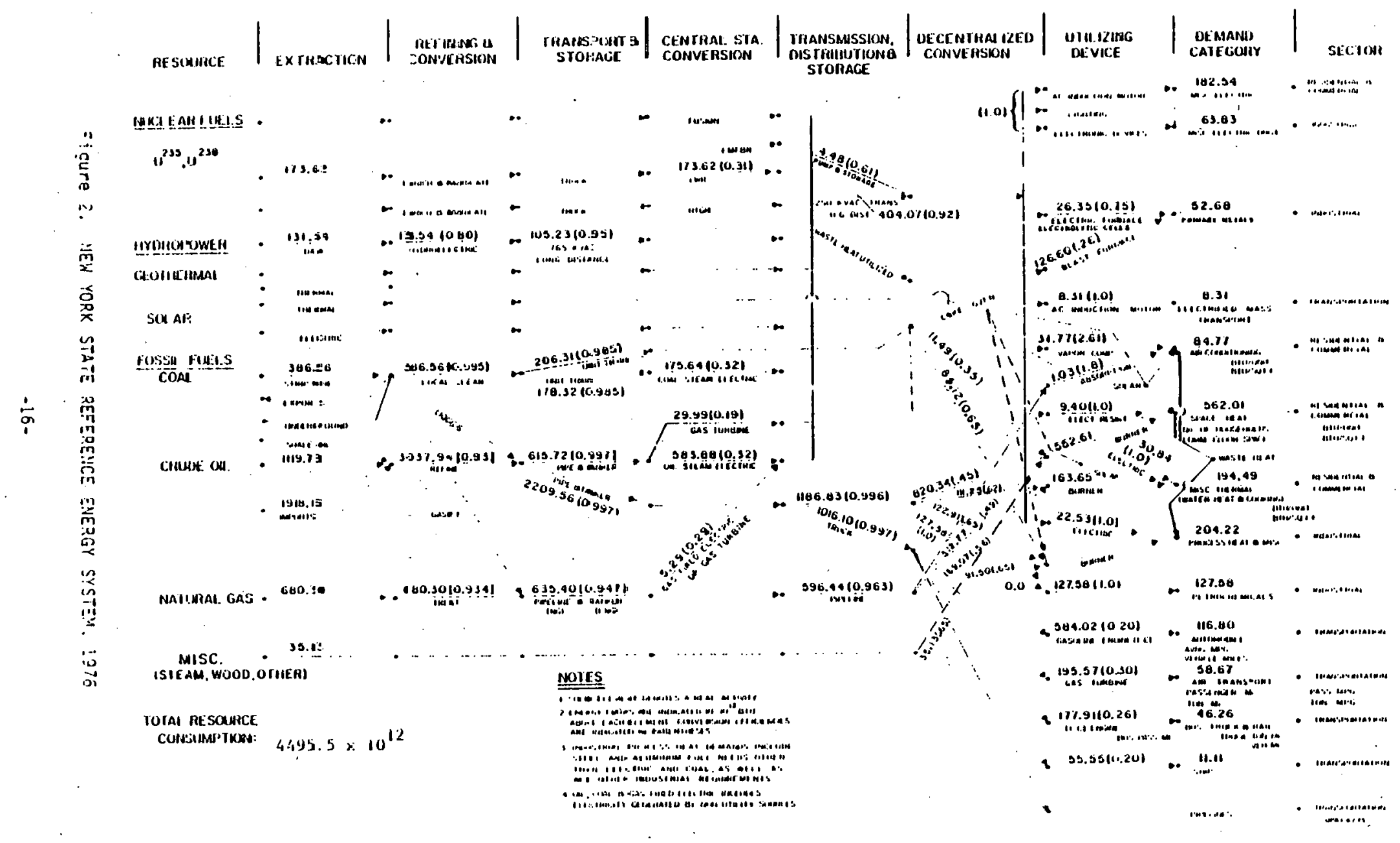


play purposes in this report depict only the efficiency coefficients (shown in parentheses). The environmental coefficients, which at this point include only air pollutant emissions, are discussed in Section XIII of this report.

The RES representation allows one to calculate the amount of a particular energy resource (e.g., oil) used to satisfy a particular demand (e.g., space heating) either through a particular intermediate fuel form, such as electric or directly. It al so allows one to calculate the gross environmental impacts (emissions) associated with a particular supply pattern or set of patterns.

\subsection{DATA INCLUDED IN THE DATA BASE}

Total demands for $0 i 1$ and oil products, natural gas, coal and electricity are aggregated from specific demand in the residential, commercial, industrial transportation, governmental and agricultural sectors of New York State. The electrical sector supplies electric energy to the six sectors listed above and requires fuel inputs already mentioned in addition to uranium and hydro-power. The energy requirements of a small utility steam sector are considered as wel1.

Future energy demand is projected by considering the underlying determinants of demand--the energy services required and then the efficiency with which various fuels are used to provide those services. More explicitly, the data listed below are included under the following heading.

1. Subsector

2. Basis

3. Fuel Demand

4. Total Fuel Demand

5. Relative System Efficiency for example, in the transportation sector, passenger or freight; in the residential sector, single family or high-rise dwellings.

$B$, a projection variable which conveniently characterizes change in the subsector: for example, in the commercial sector the principal determinant of energy usc is the amount of floorspace.

$D_{i}$ is the quantity of a fuel $i$, actually consumed in a specific demand category, such as residential space heating or commercial air conditioning.

$D_{S}$ is the total fuel required to satisfy the requirements of a specific demand category. Electricity is considered as a fuel in this sense and

$$
D_{S}=\sum_{i} D_{i} \text {. }
$$

$e_{j}$, is the relative effectiveness with which fuel $i$, is used in a demand category. This parameter depends on the utilization technology employed. For space heating, $e_{j}$ is defined as 
1.0 for existing electrically heated homes. The values of $e_{i}$ for other structures are given in the fuel mix tables.

6. Degree of Saturation

7. Unit Energy Demand

8. Technology Fraction
$S$, is the fraction of the potential demand for a particular energy use actually being fulfilled at a given time. For example, if $95 \%$ of all households have refrigerators and the potential demand for refrigerators is taken to be one per household $S=0.95$.

$E_{u}$, is the amount of energy per unit that would be required for a specific end use, assuming a relative system efficiency, $e_{i}$, of $100 \%$ for each fuel employed. Thus, for a given end use, the actual fuel demand per unit is $E_{u} / e_{j}$. where $e_{j}$ is the actual relative system efficiency.

$f_{i}$ is the number of energy consuming units satisfied by fuel $i, \Sigma f_{i}=S \cdot B$.

By specifying the technology fraction $f_{j}$, and relative system efficiency $e_{i}$, the fuel demand $D_{j}$, can be derived by the equation:

$$
D_{i}=\varepsilon_{u} \times f_{i} \div e_{j}
$$

The data described above appear in the Fuel Demand Tables displayed in Appendix A for each subsector of the six energy consuming sectors.

\subsection{SAMPLE CALCULATIONS}

The following is a sample calculation for space heating of commercial office space fuel demands.

$$
E_{u}=\text { Unit Demand }=142.00 \times 10^{3} \mathrm{Btu} / \mathrm{sq} . \mathrm{ft} \text {. }
$$

\begin{tabular}{|c|c|c|}
\hline Fuel & Technology Fraction $f_{i},\left(\times 10^{6}\right)$ & Efficien \\
\hline $\begin{array}{l}\text { oil } \\
\text { Gas } \\
\text { Steam }\end{array}$ & $\begin{aligned} 346.71 & \text { sq. ft. } \\
68.43 & \text { sq. ft. } \\
41.06 & \text { sq. ft. }\end{aligned}$ & $\begin{array}{l}.52 \\
.53 \\
.65\end{array}$ \\
\hline
\end{tabular}

Fuel Demand $=D_{i}=E_{u} \times f_{j} \div e_{i}$

For oil: $D_{1}=\left(346.71 \times 10^{6} \mathrm{sq}\right.$. ft. $) \times\left(142.00 \times 10^{3} \mathrm{Btu} / \mathrm{sq} . \mathrm{ft}.\right)+(.52)$ $=94678.5 \times 10^{9} \mathrm{Btu}$

For gas: $D_{2}=\left(68.43 \times 10^{6} \mathrm{sq}\right.$. ft. $) \times\left(142.00 \times 10^{3} \mathrm{Btu} / \mathrm{sq}\right.$. ft. $) \div(.53)$ $=18334.1 \times 10^{9}$ Btu

For steam: $D_{3}=\left(41.06 \times 10^{6}\right.$ sq. ft. $) \times\left(142.00 \times 10^{3} \mathrm{Btu} / \mathrm{sq}\right.$. ft. $) \div(.65)$ $=8970.0 \times 10^{9}$ Btu

Total Fuel Demand $=\Sigma D_{i}=121,982.6 \times 10^{9} \mathrm{Btu}$ 


\subsection{THE ESNS VERSION OF THE NEW YORK STATE RES}

The NYS-ESNS model, using the RES framework developed for New York State, describes quantitatively the flow of energy within the state from resources (indigenous and imported) through the refining, conversion, and transportation processes to the ultimate consumers of the final products (see Figure 7 ). In addition, the monetary cost of each pathway, as well as its environmental impacts as measured by the air and water residuals generated by the energy flows, can be specified and summed over all pathways to provide a total system view. The current New York State Data Base provides information on seven air residuals (particulates, oxides of nitrogen, oxides of sulfur, hydrocarbons, carbon monoxide, carbon dioxide, and aldehydes) for major energy supply and end use categories. The capability to incorporate information on water pollutants, toxic substances, and energy facility costs exists and can be utilized as data become available in the future.

The NYS-ESNS model representation of the New York State RES is designed to be used in the following way: A projection is made of the fuels or energy services to be provided in some future reference year. (By energy services are meant the levels of energy-using activities, such as vehicle-miles traveled or number of households heated). Assumptions are then made about the technologies which use these fuels to supply energy services. (Alternatively one can start with estimates of the energy services themselves and then determine the fuel mix required to supply them). Engineering economic assumptions are made about the energy supply and conversion processes within the energy system so that a complete supply and conversion picture is assembled for the future year. The model then can be used to analyze the implications--in terms of resource consumption, costs, ${ }^{*}$ capital requirements, ${ }^{*}$ etc.--of al ternative resource and technological assumptions. For example, one can examine the impact on resource consumption of a change in the level of energy services, or the impact on the environment of increases in process efficiencies at various points in the system, or the system-wide impacts of the introduction of solar energy technologies.

In one sense the RES/NYS-ESNS framework should not be considered a "model"in that there are no decisions made internal to the framework. Allocations of different energy forms or fuels would be specified exogenousiy. Nonetheless the term model may be applied to the framework in that it is a quantitative representation of New York State's energy system.

*Costs and capital requirements are not presently available in the NYS-ESNS model. 


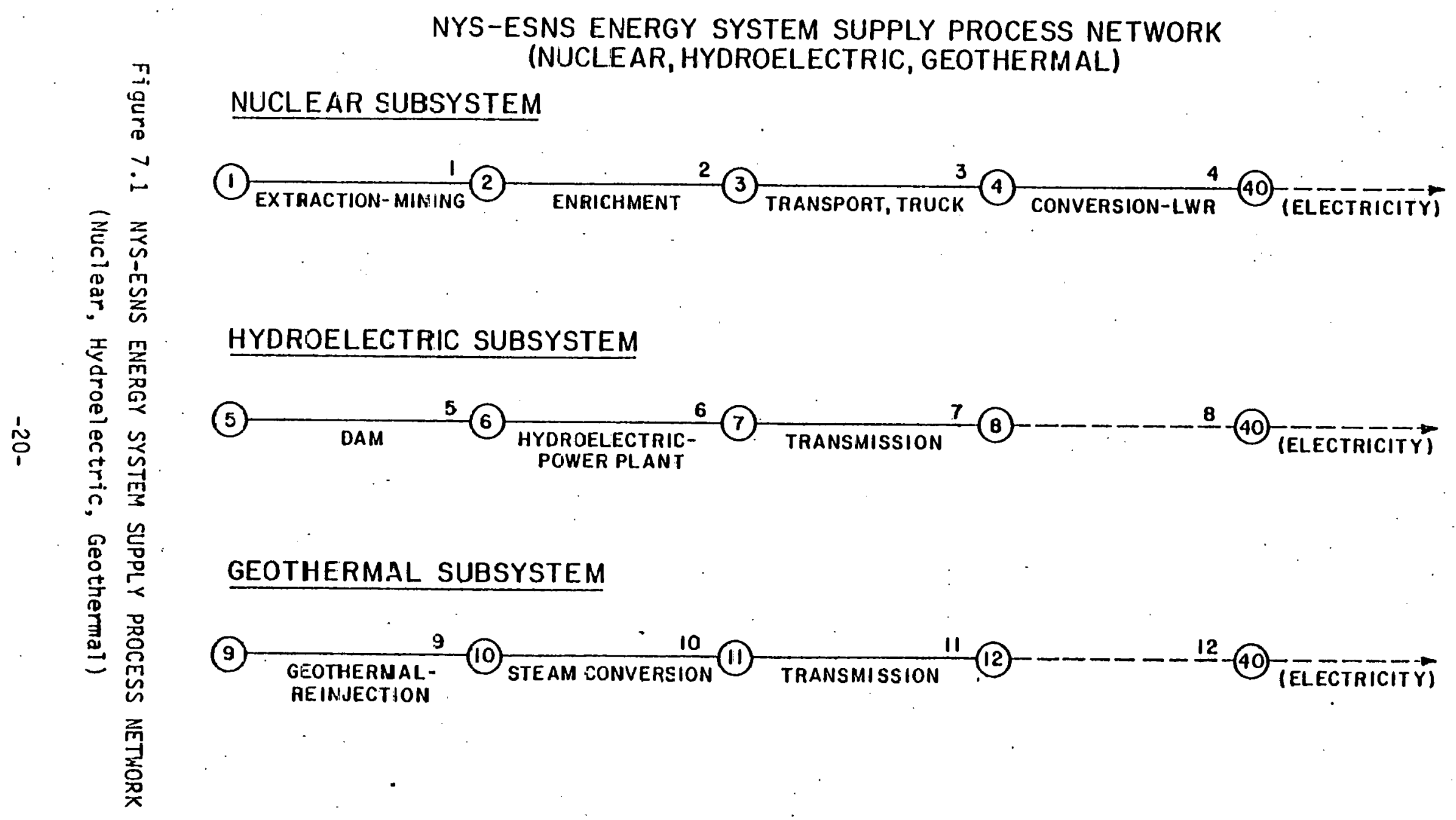


NYS-ESNS ENERGY SYSTEM SUPPLY PROCESS NETWORK

(PUMPED STORAGE HYDRO, SOLAR, COAL)

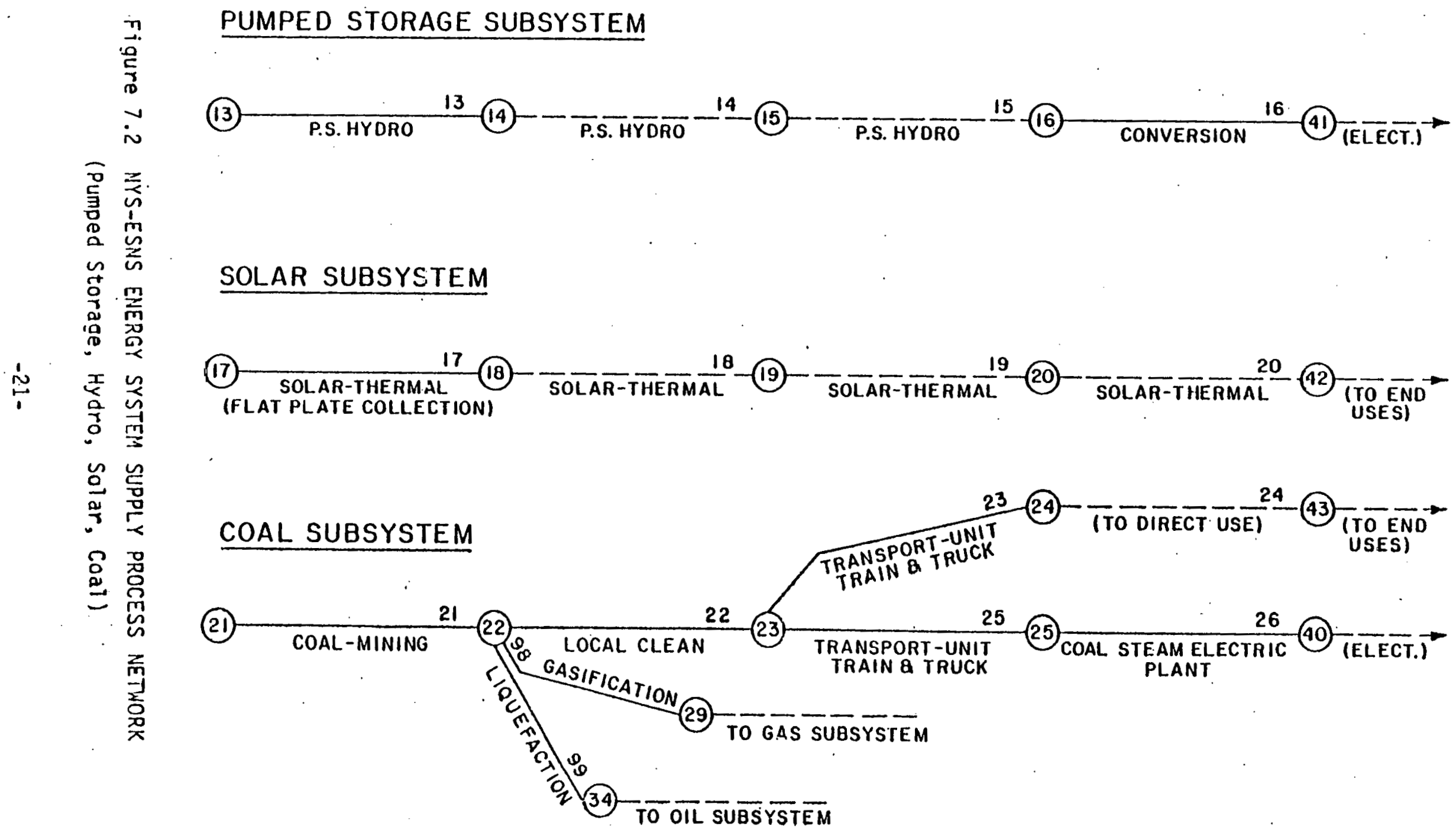




\section{NYS-ESNS ENERGY SYSTEM SUPPLY PROCESS NETWORK}

(OIL, NATURAL GAS, OTHER)

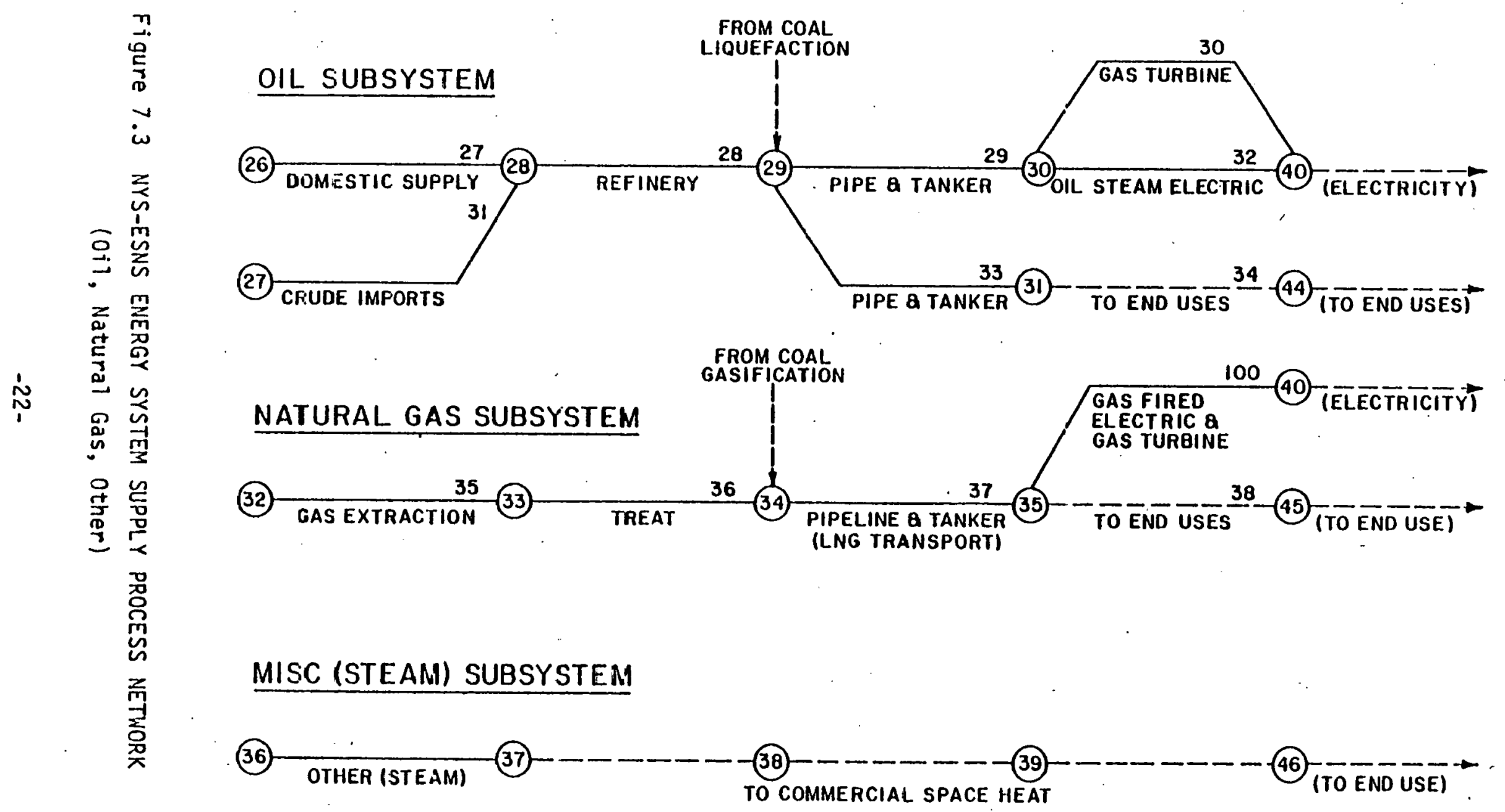


INTERMEDIATE LINKS

(40)

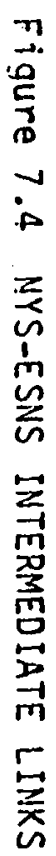

(47)

INTERMEDIATE ELECTRICITY

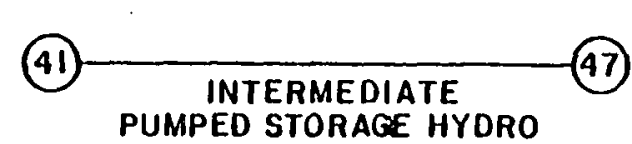

(47)

(44)

INTERMEDIATE

OIL

(50)

(46)

INTERMEDIATE

STEAM
(50) GAS
GAEDIA

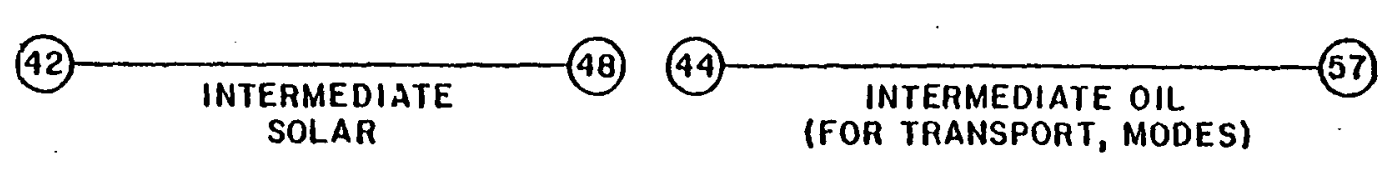


NYS - ESNS UTILIZATION PROCESS NETWORK

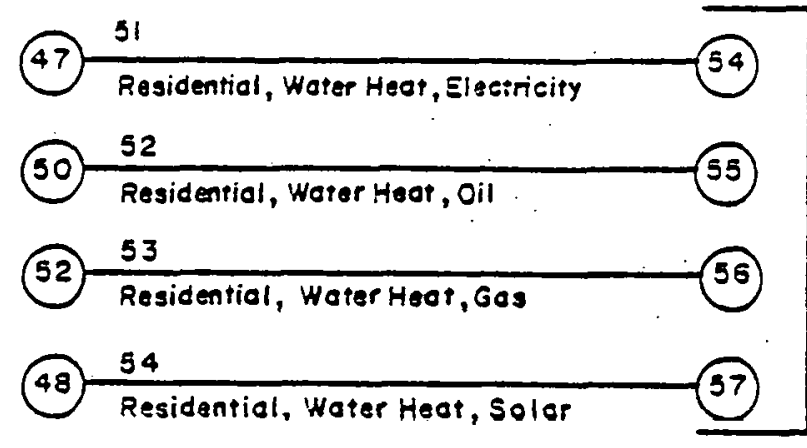

Residential

Worer Heat

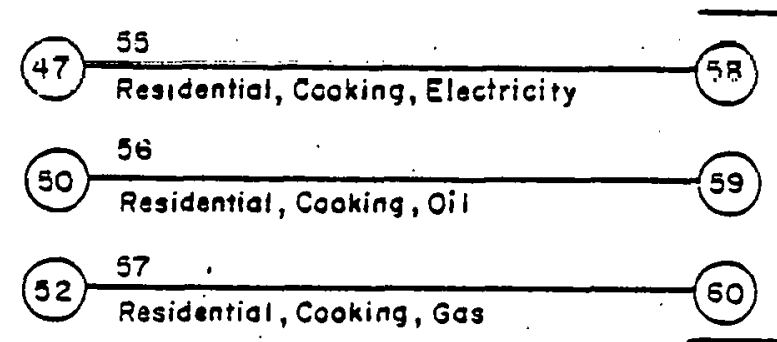

Pesidential

Cooking

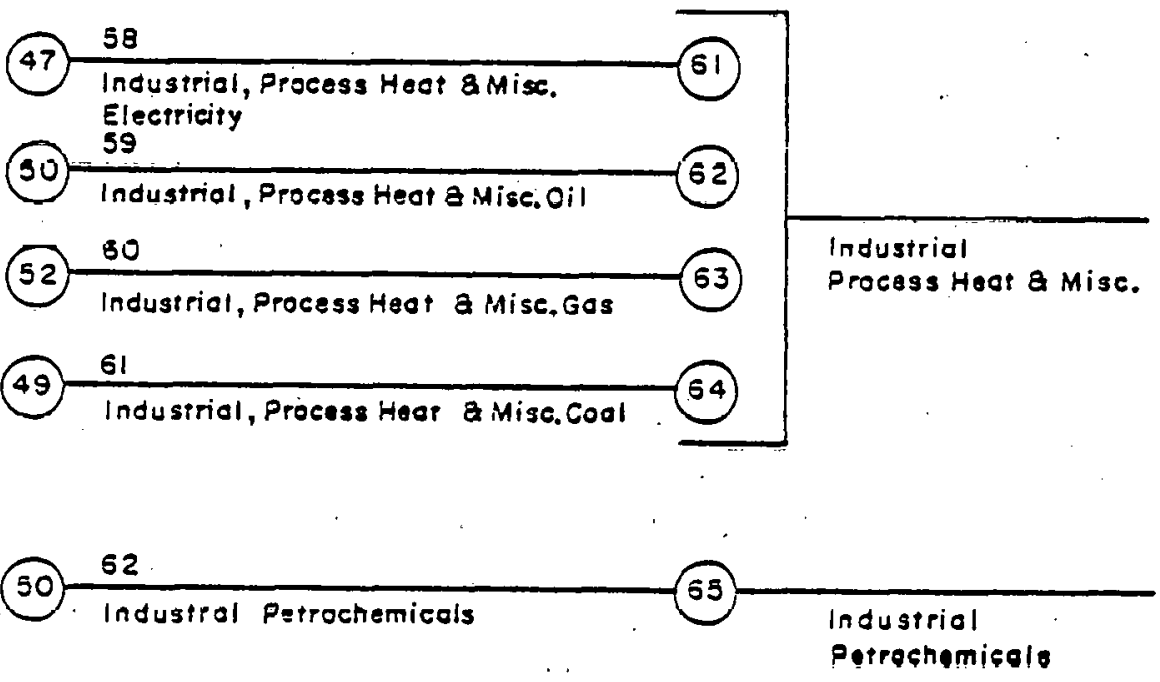

FIgure 7.5 MYS-ESNS UTILIZATION PROCESS NETWORK

(Residential Water Heat \& Cooking; Industrial Process Heat, Misc., Petrochemicals) 
NYS - ESNS UTILIZATION PROCESS NETWORK

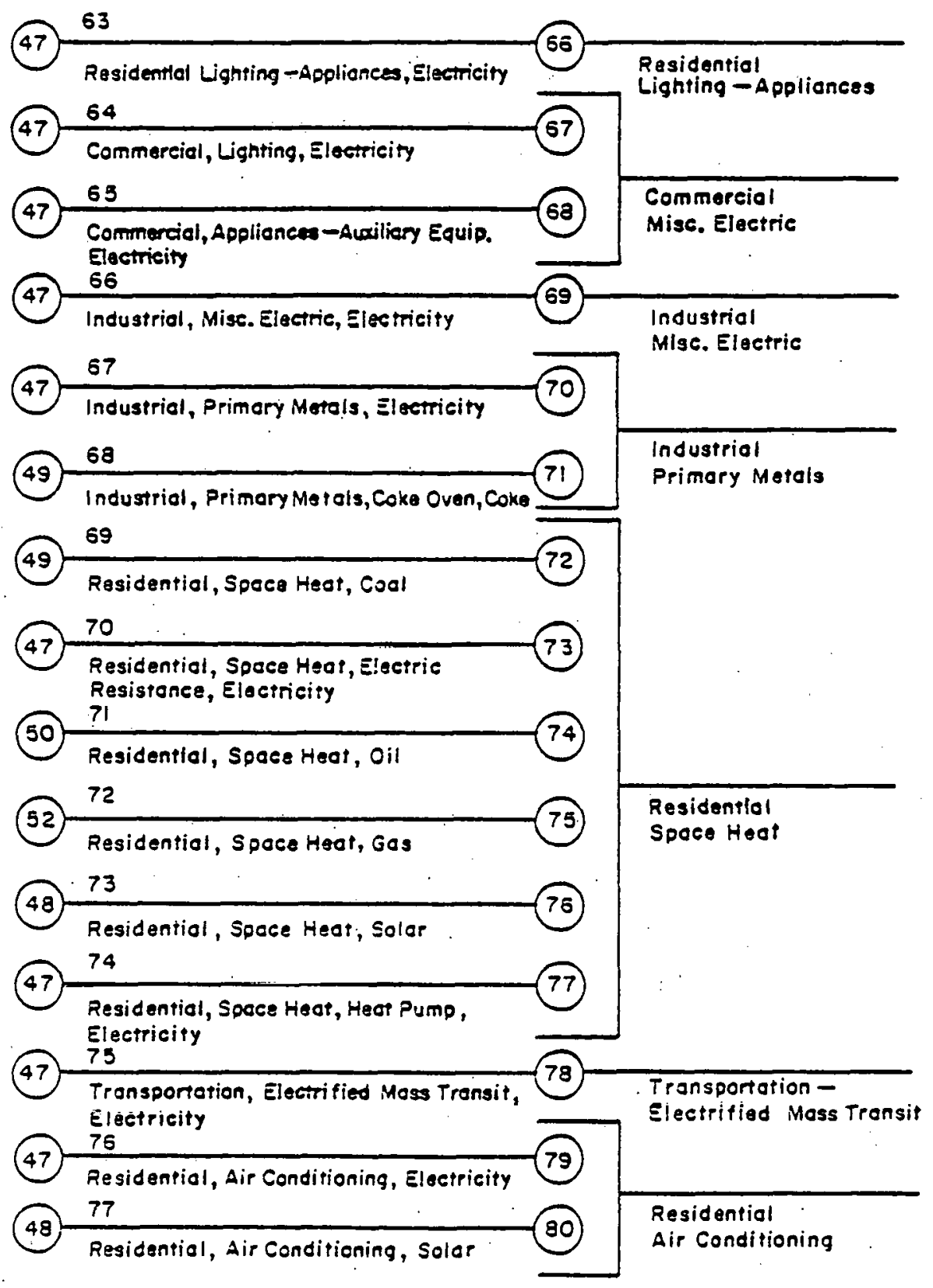

Figure 7.6 NYS-ESNS UTILIZATION PROCESS NETWORK

(Residential Lighting, Appliances, Space Heat, Air Conditioning; Comercial

\& Industrial Misc. Electric; Transportation, Electrified Mass Transit) 
: NYS-ESNS UTILIZATION PROCESS NETWORK

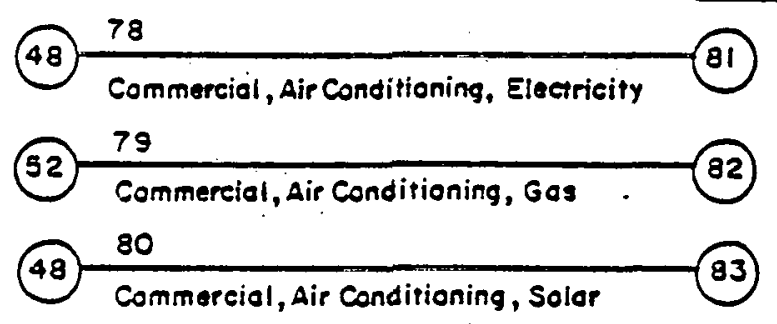

Commercial

Air Conditioning

47

81

Commerciol, Spoce Heot, Elect. Resist. Electricity

50

32

Commercial, Space Heat, öil

52

83

Commercial, Space Heat, Gas

(86)

(48) $\frac{84}{60 m m}$

Commercial, Spoce Heot, Solar

87

(47) 85

Commercial, Spece Heat, Hoot Pump Electricity

(47) 86

Commercial, Water Heat, Electricity

(52) 87

Commercial, Water Heat, Ges

(50) 88

Commercial, Watar Heat, Oil

4889

Commerciol, Wotar Heot, Solop

Figure 7.7 AYS-ESNS UTILIZATION PROCESS NETWORK (Commercial Air Conditioning, Space Heat \& Water Heat). 


\subsection{ESNS INPUTS}

The input information required to operate NYS-ESNS includes the overall supply and demand structure of the energy system, the magnitude and type of energy demand, the efficiency of each technological process represented, the market allocation of each process and, if available, cost and environmental residuals data. The model as currently constructed does not contain a projection component, but depends upon exogenously specified demands.

The input components to NYS-ESNS are described briefly below:

1. New York State Reference Energy System

The structure of the New York State Reference Energy System described above is the primary input to the NYS-ESNS model. The details of the NYS-ESNS representation of the New York State RES are provided in Chapter IV.

\section{Energy Demand}

Demand for energy drives the NYS-ESNS model. The model calculates the level of energy resources and imports required to satisfy a specified mix of demand types.

Demand for energy can be quantified for input into ESNS in three ways:

a. Direct Fuel Consumption (DFC) - the amount of fuel $(x)$ in BTUs delivered to a particular end use category,

b. Basic Energy Demand (BED) - the amount of energy in BTUs which represent the useful energy required by the particular demand category,

c. Measure of demand activity (measure) - the level of energy service required expressed in units of activity i.e., passenger-miles traveled for automobiles.

Demand expressed initially as basic energy demand or measure is converted within the model to direct fuel consumption by the use of numbers to represent the efficiency of end use (see Section 2.7 Calculations).

\section{Efficiencies}

Efficiency can be represented in NYS-ESNS in three different ways: primary efficiency, relative effectiveness and energy demand per measure.

Primary efficiency, used in all supply processes, is defined as the ratio of useful energy out of the process to primary energy delivered to the process. Fuel of a type other than the primary fuel which may also be required by the process, called ancillary fuel, is not included in the calculation of the primary efficiency (see Figure 8). Overall efficiency, taking into account ancillary energy requirements, is not computed in NYS-ESNS. 


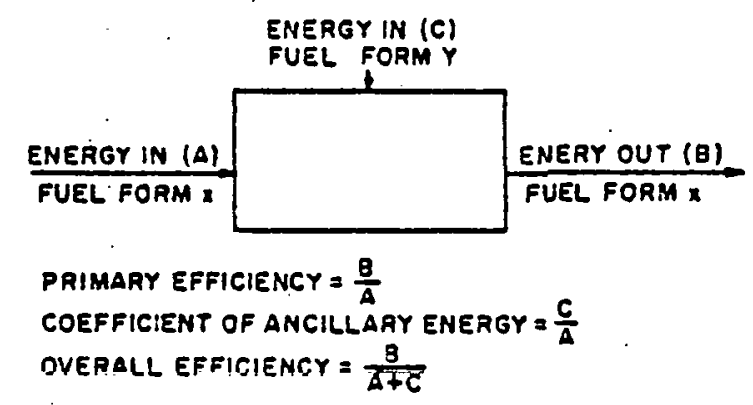

Figure 8. ENERGY BALANCE FOR PROCESS.

Relative Effectiveness is the concept used to describe the efficiency of end use devices. Relative effectiveness is distinguished from primary efficiency in that, in addition to reflecting the technical efficiency of the end use device (process), it incorporates other differences among fuels serving the same function.

For example, all-electric houses tend to be more heavily insulated than houses that are heated with oil. The relative effectiveness of electric and oil-heated houses reflects this difference.

The arithmetic product of fuel delivered to the end use device (or process) and the relative effectiveness is the basic energy demand (see Section 2.7 Calculations).

Energy Demand Per Measure is used to convert demand expressed in units of use to direct fuel consumption, or conversely to transiate fuel consumed by an end use function into units of use.

The demand-efficiency type combination selected for input to ESNS depends on both the available data and the demand projection methodology (which operates external to the model). For example, if demand for energy in a future year is projected by determining the level of energy consuming activity in that year, then the demand efficiency type chosen would be energy per measure.

4. Market Allocations

An RES diagram displays the choices that are available to supply a particular fuel form to a specified use. When more than one option exists to supply a process with the energy it needs, the relative magnitude of each of 
the supply shares of that technology is expressed.as the fraction of the total market for the product.

5. Other Parameters

Using only the RES structure, demands, efficiencies, and allocations, NYS-ESNS can calculate energy flows through the system. However, additional optional inputs can greatly enhance the usefulness of the model.

A list of optional parameters which can be included in NYS-ESNS follows. These include process efficiency components, residuals discharged to air and water, land use, occupational health, and fixed and operating costs. These data are inserted into the model in the form of units/1012 BTUs input to the process.

\subsection{CALCULATIONS}

Flows of energy represented by the RES diagram are calculated from demand to supply (right to left).

Very simply, on the supply side of the RES the energy available to any node is split according to the market share of each of the processes which deliver energy to that node, yielding the energy out of each process. The energy out of the process is divided by the primary efficiency of the process to yield the energy into the process. This sequence is repeated until all energy flows on the supply side of the RES have been calculated.

On the demand side, three different calculations are made, depending upon which demand input type is entered into NYS-ESNS. If Direct Fuel Consumption (DFC) is provided, no calculation needs to be made. Optionally, if either Basic Energy Demand (BED) or measure is desired, and the proper efficiency is supplied, these can be calculated from DFC.

When BED is entered, it is divided by the relative effectiveness to give DFC. Measure multiplied by energy demand per measure, yields DFC.

When all the energy flows in the network have been calculated, then the residuals and costs associated with each process for which a coefficient has been previously entered are calculated. Since the coefficients are expressed in units/1012 Btu of eneray input to the process, the calculation is to multiply the coefficient by the total energy flow into the process.

As can be inferred from the calculations, NYS-ESNS is primarily an accounting model. Given certain data inputs and demand assumptions, a snapshot of the energy system at one point in time is produced, with energy flows and associated parameters sumed and the required resources and imports tabulated. 


\subsection{OUTPUTS}

The output of NYS-ESNS is available in two basic formats; an inverted listing and a production run listing.

Table 3

OPTIONAL PARAMETERS FOR NYS-ESNS

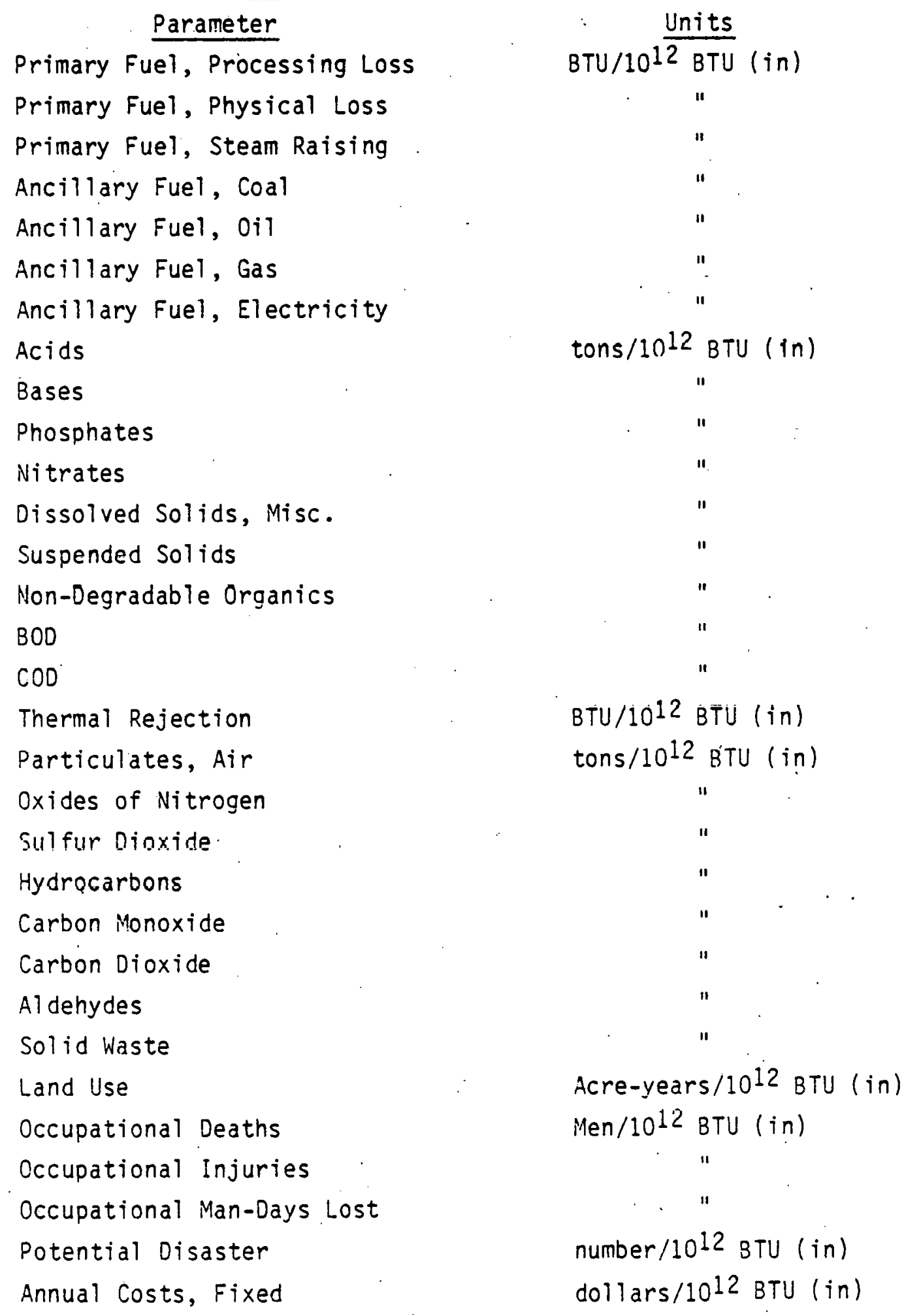


Table 3 (Continued)

OPTIONAL PARAMETERS FOR NYS-ESNS

\begin{tabular}{|c|c|}
\hline Parameter & Units \\
\hline Annual Costs, Operating & dollars/1012 BTU (in) \\
\hline Total Costs & $"$ \\
\hline Population Exposure, Radiation & man-rem/1012 BTU (in) \\
\hline High-Level Radioactive Waste & curies/1012 BTU (in) \\
\hline Tritium Emission & $"$ \\
\hline Krypton Emission & $"$ \\
\hline Energy Demand per Measure & BTU/Measure (varies) \\
\hline Direct Fuel Consumption & BTU \\
\hline Basic Energy Demand & BTU \\
\hline Aqueous Ammonia. & tons $/ 10^{12}$ BTU (in) \\
\hline Trace Elements & $"$ \\
\hline Hydrochloric Acid & $"$ \\
\hline Hydrogen Cyanide & $"$ \\
\hline Anti-biofouling agent & $"$ \\
\hline Hydrogen Sulfide & $"$ \\
\hline Carbonyl Sulfide & $"$ \\
\hline Armonia & " \\
\hline Photochemical oxidents & $"$ \\
\hline Boron & " \\
\hline Make-Up Water & acre-ft/1012 BTU (in) \\
\hline Plant Volume & cubic feet-year $/ 10^{12}$ BTU (in) \\
\hline Radon-222 & Curie/1012 BTU (in) \\
\hline Thorium-230 (Air) & $"$ \\
\hline Transuranics & " \\
\hline Radium-226 (Air) & 13 \\
\hline Uranium (Air) & " \\
\hline Iodine-131 & $"$ \\
\hline Misc. Fission Products (Air) & $"$ \\
\hline Noble Gases & $"$ \\
\hline Radium-226 (Liquid) & $"$ \\
\hline Uranium + Daughters (Liquid) & $"$ \\
\hline Rutheni um-106 & $"$ \\
\hline Thori um-234 & $"$ \\
\hline Misc. Fission Products (Liquid) & " \\
\hline
\end{tabular}


Table 3 (continued)

OPTIONAL PARAMETERS FOR NYS-ESNS

$\begin{array}{lc}\text { Solid Low Level waste } & \frac{\text { Units }}{\text { Parameter }} \\ \text { Solid High Level Waste } & \text { curic feet } / 10^{12} \text { BTU (in) } \\ \text { Solid Low Level Waste } & \text { BTU }\end{array}$

The inverted listing format displays; in an easily readable style, all data associated with each process and conversely, all processes which contain a certain data type. This capability allows data to be organized in a useable fashion as they are gathered, as well as permitting rapid checks of specific $i$ tems of data with corresponding numbers from other sources.

The production run listing is the output which results from an actual run of the NYS-ESNS model. Options exist which allow some user control of the detail required to be printed from a speciftc run of the model. Unless specified by the user, output of a production run includes the following sections:

1. Total effects by process for the base year considered.

For each process, NYS-ESNS displays the energy flow entering and leaving the process, indicates the efficiency and market allocation assumed for the process, and tabulates the total amounts of any environmental residual or other parameters for which a coefficient was previously entered.

2. Total effects by quantity of residual for the base year considered.

All the residuals generated by the processes represented in the current run are totaled, resulting in the tabulation of system-wide impacts.

3. Total resources consumed for the given run.

The energy resources required, by fuel type, to satisfy the demands of the current run, are given in units of total BTUs consumed.

4. Total end use energy demands by fuel type and by sectors.

The quantity of fuels by type delivered to each utilization sector are given in BTUs, then summed across all sectors and finally across all fuels.

5. Bastc Energy Demands.

The useful energy reauirements (after the end use device efficiencies are accounted for) are summed for categories of interest in demand projection and planning. The units are BTUs of useful energy required rather than of a specific fuel type.

Optional output information which can be specified by the user includes (1) the energy flow into or out of any set of processes specified by the user, as well as the impacts of residuals generated by the selected process set; (2) output of processes by 'sector. 


\subsection{PERTURBATIONS}

Given the inputs discussed above, NYS-ESNS will reproduce a base-case RES for New York State for a previously designated base year. However, the greatest utility of the model lies in the ability to modify any or all of the inputs and observe the changes resulting from these new inputs.

Modifications to a base case model run can be made by

a) substitution of a new value of any input variable for the original base case number,

b) addition of a value for a parameter in a particular process for which no previous value was indicated,

c) addition of new processes anywhere on the supply or demand side which were not present in the original New York State RES diagram,

d) specification of a maximum energy flow for any supply process represented in the RES. Should this flow be exceeded the excess will be redistributed among all competing processes (i.e., processes which supply the same energy product) in proportion to their original market allocation. Alternatively, it is possible to specify a priority of redistribution for the excess energy flow.

When any or all of these changes are made to a base or reference case, a perturbation case is calculated in which the effect of the modifications on the resources and imports are summed and the new flows through each process, as well as the residuals generated by these flows, are calculated. In addition, a comparison of any two cases, perturbation or base, can be printed if desired. Three types of perturbation runs involving less than the full system runs described above are especially useful to make with the NYS-ESNS model.

A trajectory is a single pathway which can be traced through the entire system. If all other demands and market allocations are set to zero, then only the residual effects and magnitude of flows of the trajectory of interest are calculated and displayed. This technique can be used for example, to examine alternate supply possibilities for a given demand.

Somewhere between a full system run and a single trajectory lies consideration of a subsystem of the full energy system. A subsystem can display the portion of an energy supply system which serves only one type of demand, e.g., electric demand or a subset of energy demand. This option allows a portion of the RES to be examined without allowing the effects of the rest of the supply system to obscure the impacts of interest.

Finally, the impact of introducing a new technology or set of technologies on the existing or future reference energy system can be evaluated and compared to other possible energy supply strategies. 


\section{REFERENCES TO CHAPTER II}

1. Associated Universities, Inc., "Reference Energy Systems and Resources Data for Use in the Assessment of Energy Technologies," AET-8, April 1972 and M. Beller, Ed., "Sourcebook for Energy Assessment," BNL-50483, Brookhaven National Laboratory, December 1975.

2. J. Allentuck et al., "An Assessment of Energy Research, Development and Demonstration Priorities for New York State," BNL-50735, Brookhaven National Laboratory, Upton, New York, November 1977.

3. W. A. Sevian, "The Energy Systems Network Simulator (ESNS): General Description and Sample Analysis," BNL-50492 (September 1975), Brookhaven National Laboratory, Upton, New York. 


\section{CHAPTER III}

THE NATIONAL ENERGY PLAN AND THE NEN YORK STATE REFERENCE CASE

In another report we described the way in which the consequences of the National Energy Plan (NEP) for the U.S. energy economy were derived.1 For ease of reference we repeat this description in the paragraphs which follow.

The level of services in the projection year in terms of Basic Energy Demand represented on the right-hand-side of the RES, is computed using a series of economic models. Long-run trends of consumption and investment are obtained from the DRI macroeconomic growth model and supplied to the ORI inter-industry energy model. The economic output obtained from the inter-industry model is then applied to energy-related coefficients from the BNL input-output model, resulting in the Btu final demands shown on the right hand-side of the R.ES.

For 1985, the mix of fuels satisfying these final demands are set equal to the fuel mix specified in the NEP outiined by the Executive office of the President-Energy Policy and Planning. New technology implementation levels are determined by the U.S. Department of Energy.

Efficiency improvements are detemined from specific proposals in the NEP. Proposals in the building sector, for example, include a homeowner tax-credit of 25 percent of the first $\$ 800$ and 15 percent of the next $\$ 1400$ spent on approved conservation measures. These proposals are translated into end-use device efficiency improvements such as a reduction in average heat loss per housing unit from an estimate of the number of new and retrofit housing units having a given level of conservation due to fuel prices, tax incentives and other policy proposals as illustrated above.

The implications of the NEP are reflected in the NYS reference case on the demand side in several ways: changed efficiencies of conventional technologies, substitution of other fuels for $0 i l$ and gas, and market penetration of innovative technologies. On the supply side it has consequences for our study by increasing the quantity of coal which otherise would be available nationally.

These changed efficiencies of conventional technologies, market penetrations of new technologies and fuel substitutions derived from the national case were transferred with only few modifications to the NYS case. In the present study we have reconsidered the impact of these changes on New York's energy economy in the light of the failure of the national government to 
complete action on the NEP* and the modification or elimination of a number of the original proposals. In addition we have reconsidered our estimate of the effect of conservation in electricity demand in the residential sector. In the paragraphs which follow we examine in detail our revised assumptions.

\subsection{RESIDENTIAL AND COMMERICAL SECTORS}

The following paragraphs and tables describe the various reference case projection assumptions for the residential and commercial sectors. The national projections actualiy combined these two sectors, but we have attempted to separate them where possible. In each we review our previous assumptions as to consequences of the NEP for end use efficiencies and market penetration.

In Table 4 we summarize assumptions as to energy efficiencies in 1976 and 1985 in these sectors. It will be noted that our current assumptions are generally more pessimistic than in the past report. The projected market penetration of innovative technologies is displayed in Table 5. Table 6 describes the market share of electric energy in space and water heating in 1985. The use of electricity is expected to increase over its 1976 value though it will be seen to be somewhat less than in our 1977 study for NYS ERDA. 1

Conservation is also expected to play a role in the 1985 electricity consumption. We anticipate a reduction in the amount of electricity used for lighting in both the residential and commercial sectors. It is expected that appliances will become more efficient. These decreases in unit demands for lighting and appliances were not taken into account in the NYS ERDA Study. Table 7 describes unit demand changes in commercial and residential end use which are attributed to conservation and improved efficiency.

*The act was passed subsequent to the completion of the work reported here. 


\section{Table 4}

EFFICIENCIES: COMMERCIAL/RESIDENTIAL SECTOR

\begin{tabular}{|c|c|c|c|c|c|}
\hline & & & & & \\
\hline & & & This & घdy & NYS ERDA Study \\
\hline & Res & Com & $\overline{\text { Res }}$ & Com & Res/Com \\
\hline Space heating & & & & & \\
\hline $\begin{array}{l}\text { Oil } \\
\text { Gas }\end{array}$ & .40 & .52 & .50 & .50 & .52 \\
\hline $\begin{array}{l}\text { Gas } \\
\text { Water heating }\end{array}$ & .48 & .53 & .55 & .55 & .58 \\
\hline Water heating & & & & & \\
\hline $0 i 1$ & .63 & .63 & .63 & .63 & .63 \\
\hline Gas & .57 & .70 & .57 & .70 & .61 \\
\hline Air conditioning & & & & & \\
\hline Vapor Compression & 2.1 & 3.0 & 3.0 & 3.0 & 3.3 \\
\hline
\end{tabular}

Table 5

NYS MARKET PENETRATIONS OF NEW TECHNOLOGIES RESIDENTIAL/COMMERICAL SECTOR (\% of Total Subsector Energy Demand)

\begin{tabular}{lcc} 
& This Study & NYS ERDA Study \\
\cline { 2 - 3 } Space heating & 5 & 10 \\
Heat Pump & 0 & 0 \\
Solar & 1 & 2 \\
water Heating & & \\
Solar & &
\end{tabular}

\section{Table 6}

NYS CHANGES IN ELECTRIC ENERGY MARKET SHARE

(\% of Total 1976 subsector Energy Demand)

Space heating

Water heating

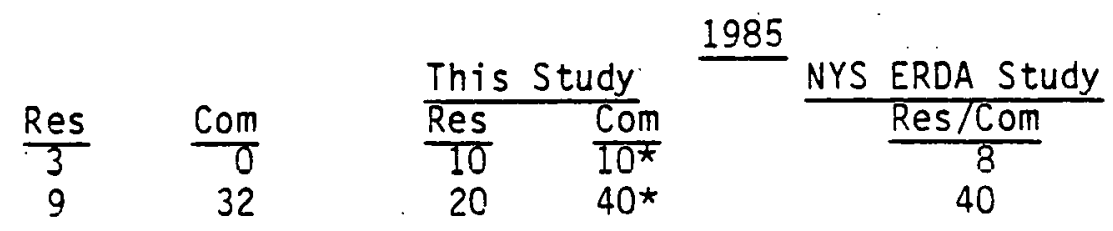

FThese values do not apply to the hospital or school subsectors. The electricity market shares remain at the 1976 level. 
Table 7

$\left(\% \frac{\text { NYS CHANGES IN UNIT DEMANDS }}{\text { Decrease in Demand, } 1976-1985) .}\right.$

Commercial Lighting

$\frac{1976-1985 \text { Decrease }(\%)}{7}$

Residential Light-Appliances

\subsection{MANUFACTURING SECTOR}

Recent trends in N.Y.: State show a move away from natural gas as an energy source to oil. and, to a lesser extent, electricity. This is probably a reaction to the gas shortage of 1976-77, and the fact that a number of industries have interruptible contracts. The use of coal as a primary fuel has not increased significantly. The NEP will encourage a shift away from gas and oil toward coal. However, the NEP has not been approved at this point, and it will take a number of years for plants to convert burners for coal use. Gas burners can also be converted to use oil more easily than they can be converted to use coal. Therefore, we anticipate a continued short term shift from natural gas to oil and electricity, though a long term shift to coal might occur. This represents a change from our view in the NYS ERDA study which assumed a substantial shift to coal for process heat by 1985 .

Industrial energy demands were initially projected to 1985 , and included some efficiency improvements in the industrial processes. To account for the anticipated shifts described above gas demand was then reduced by $20 \%$ and oil and electricity were increased in equal amounts to compensate for the gas reduction.

\subsection{TRANSPORTATION}

Present legislation mandates certain improvements in fuel economy of the auto fleet by 1985. The 1985 national average automobile fuel economy is expected to be 18.35 miles per gallon and this is reflected in the N.Y. reference case estimates.

Improved efficiencies are al so anticipated for other modes of transportation. These occur from increased passenger or freight loads and are accounted for by improved unit demands. These improvements are described in Table 8 for each subsector in the Transportation Sector. 
Table 8

TRANSPORTATION SECTOR UNIT DEMANDS $\left(\right.$ Btu $\left.\times 10^{3}\right)$

$\begin{array}{lrr}\text { Auto } & \frac{1976}{1.29} & \frac{1985}{.96} \\ \text { Auto } & 13.06 & 10.93 \\ \text { Air-Freight } & 4.54 & 4.49 \\ \text { Air-Pass } & 2.67 & 2.67 \\ \text { Bus } & .23 & .23 \\ \text { Rail-Freight } & 1.05 & 1.00 \\ \text { Rail-Pass } & .95 & .95 \\ \text { Truck } & .14 & .14\end{array}$

\subsection{ELECTRIC UTILITIES}

For the nation as a whole the NEP is estimated to effect a shift from oil and gas to coal. However, in projecting the 1985 NYS electricity generation mix, one must take into account the present mix, plants under construction, planned plants, and the time lag necessary in constructing new plants or modifying old plants. The electric utilities in New York State already have plans for the 1985 generation mix, and it is unlikely that these plans will be changed significantly to dramatically effect the 1985 mix.

The projected 1985 national and NYS generation mixes are presented in Table 9. The national mix includes the effects of the NEP while the NYS mix reflects the New York Power Pool? (NYPP) plans.

\section{Table 9}

COMPOSITION OF ENERGY INPUT TO US AND NYS ELECTRIC GENERATION

$\begin{array}{lrr}0 i 7 & \text { USa } & \frac{N Y S^{b}}{46} \\ \text { Gas } & 2 & 0 \\ \text { Coal } & 55 & 16 \\ \text { Nuclear } & 25 & 19 \\ \text { Hydro } & 10 & 19 \\ \text { Other } & - & -\end{array}$

ancludes the effects of the NEP.

bNYPP mix for 1985 . 


\section{REFERENCES TO CHAPTER III}

1. J. Allentuck et al.,. "An Assessment of Energy Research, Development, and Demonstration Priorities for New York State," BNL-50735, Brookhaven National Laboratory, Upton, New York, November 1977.

2. "Report to Member Electric Systems of the New York Power Pool Persuant to Article VIII, Section 149-b of the Public Service Law - 1978." 


\section{NYS REFERENCE YEAR ENERGY DEMANDS}

In this chapter we start by reviewing state aggregate energy demands by consuming sector for 1976, and our projections of these demands to 1985 . Included are reviews of demand highlights in the base year and in 1985 as well. as our projection methodology. Detailed state aggregate demands are provided in Appendix A. A comparison of sectoral demands is provided in Figure 9.

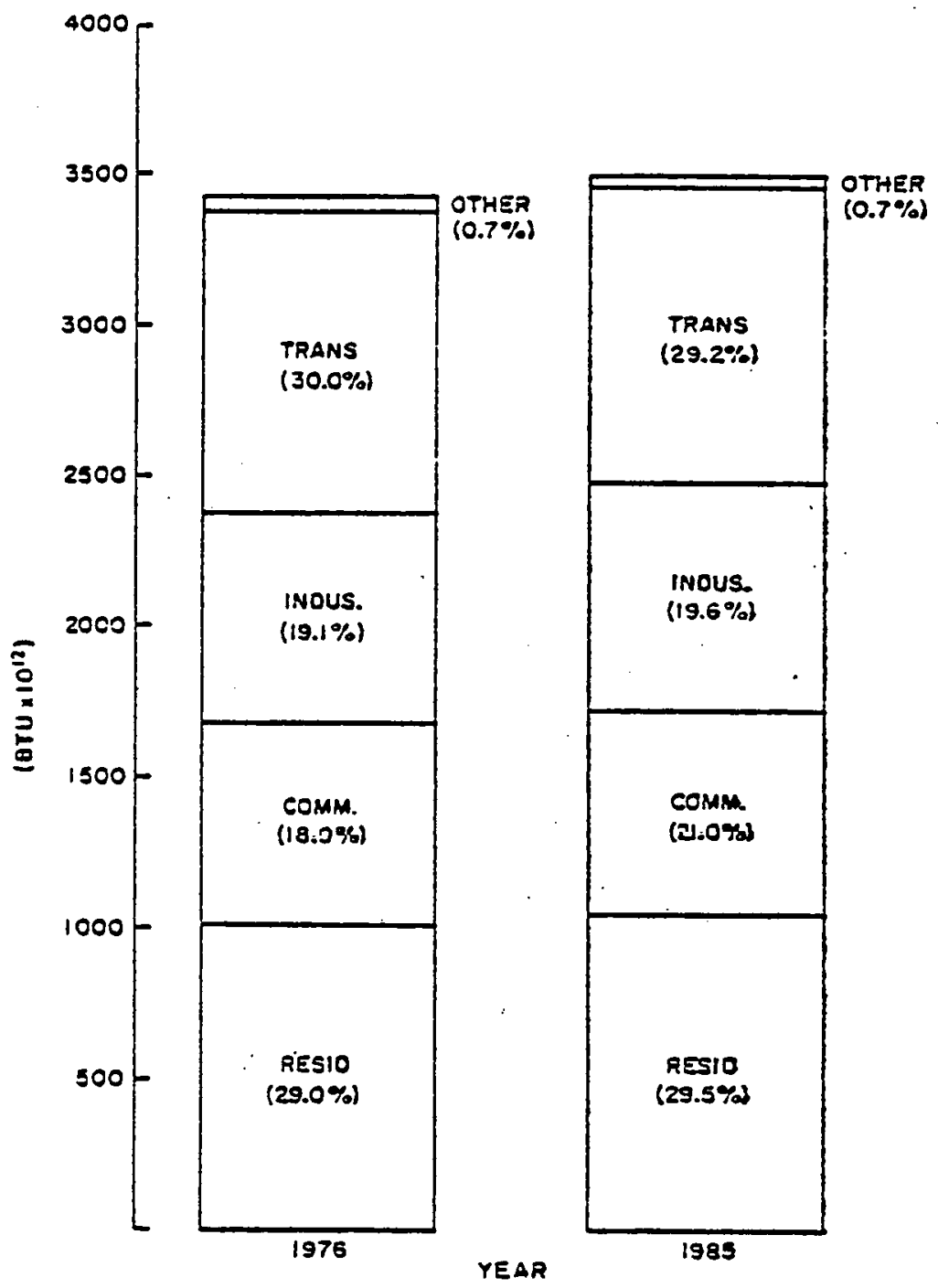

Figure 9. ENFPGY DEMAND BY SECTOR. 
In the next chapter we turn to county level energy demands and supplies as they existed in 1976. Here we review data and data sources as well.

\subsection{THE RESIDENTIAL SECTOR}

\section{1 .1 Highiights}

Highlights of energy consumption for the residential sector in each reference year are as follows:

\section{6}

o Total energy consumption: $976 \times 10^{12} \mathrm{Btu}$

o Consumes $29 \%$ of total state energy demand*

- By energy form, demands in terms of the state fuel totals* are: $0 i 124 \%$, gas $61 \%$, electricity $32 \%$

- By energy form, demands in terms of the residential energy total are: oil $51 \%$, gas $33 \%$, electricity $12 \%$

- By end use, fuel demands as a percentage of the residential fuel totals are:

Space Heating

Water Heating

Air Conditioning

Lights-Appliances

Cooking

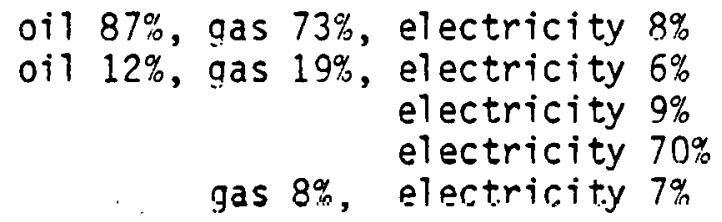

\section{5}

- Total energy consumption: $1019 \times 10^{12}$ Btu

- Consumes $29 \%$ of the total state energy demand

- By energy form, demands in terms of state fuel totals are:

oil $23 \%$, gas $62 \%$, electricity $39 \%$

n Ry energy form, demands in terms of the residential energy total are:

0 il $47 \%$, gas $33 \%$, electricity $19 \%$

$\star$ Aा state total end-use demands exclude the electric utility sector. 
- By end use, fuel demands as a percentage of the residential fuel totals are:

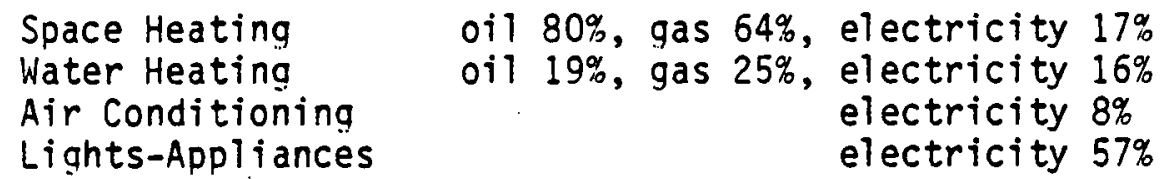

- Changes in the energy mix for space heating and hot water arise from a shift from oil and gas technologies to electric technology

- Consumption of natural gas increases $3 \%$ and $0 i 1$ decreases $5 \%$ from 1976 quantities. Electricity use increases $66 \%$

- Electricity demand for space heat increases $228 \%$, for water heat $352 \%$

- Lighting and appliances demand increases 35\% (over 1976)

- Air conditioning demand increases 48\% (over 1976)

- The impact of new technologies is small

Residential energy demands for each reference year are summarized in Appendix A. Fuel requirements for this sector are compared in Figure 10.

\subsubsection{Residential Unit Demands, Saturation, and Efficiencies}

Unit energy demands for all end uses in residential dwellings were obtained from the Brookhaven National Laboratory Report "Future Residential and Commercial Energy Demand in the Northeast" 1 and. from the Oak Ridge report, "Residential Consumption of Electricity, 1950-1970."2 These unit demands were initially reported by A.D. Little, "Residential and Commercial Energy Use Patterns," 3 for different regions of the country. Northeast unit demands were modified to apply to New York State based on heating degree values and the average dwelling unit size. These unit demands were then changed, as appropriate, to take into account more recent data from A.D. Little. 4

Changes in the unit demands for lights-appliances from 1976-1985, were included as discussed in Chapter III.

The saturation rate for space heating, water, heating, and cooking were taken as unity for all reference years. The lights-appliances saturation rate 


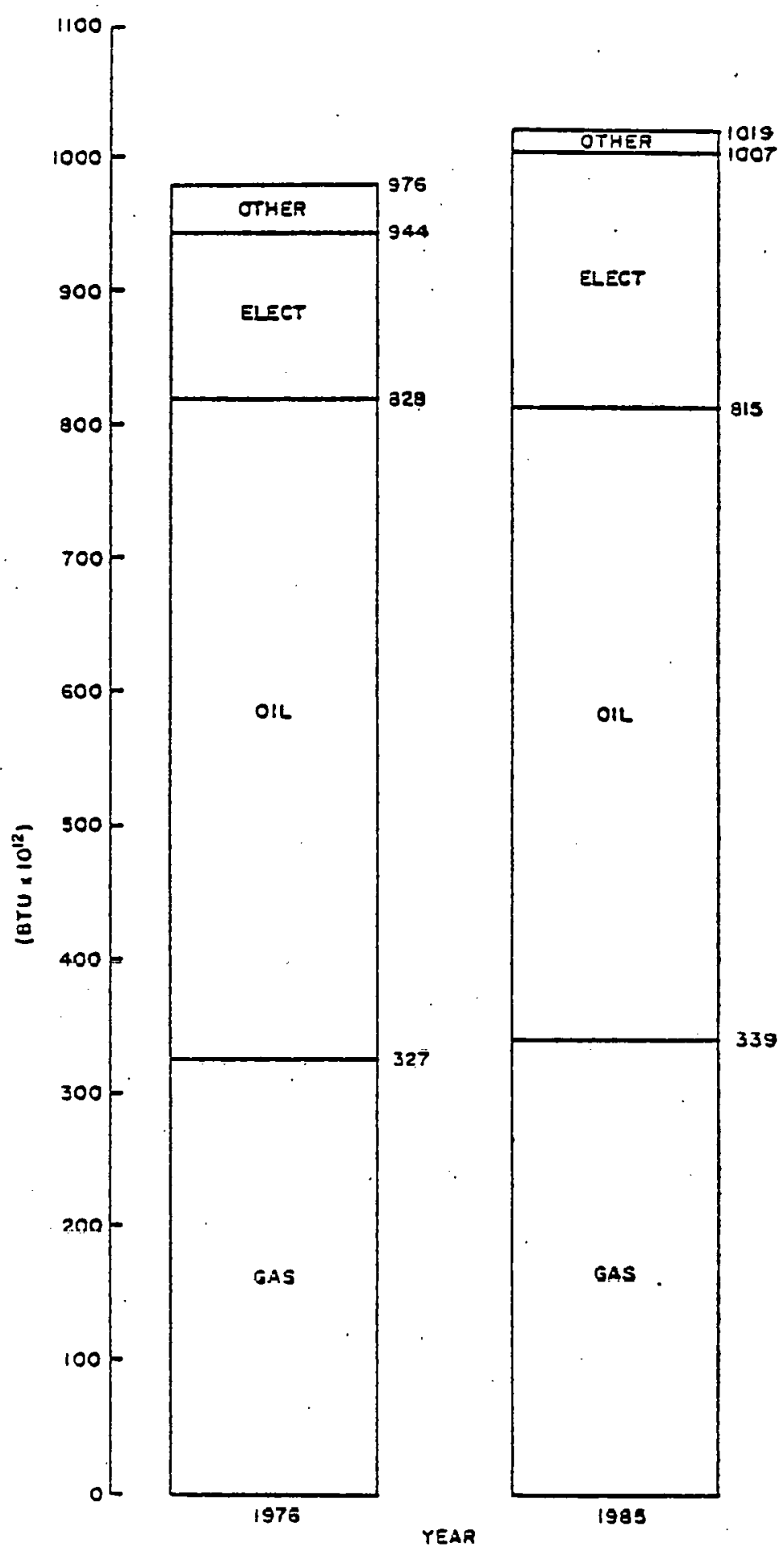

Figure 10. NYS RESIDENTIAL SECTOR ENERGY DEMAND. 
for 1976 was interpolated from the 1972 and 1985 saturation rates in Ref. 3, and its 1985 saturation rate was also taken from this source. The air conditioning saturation rate was initially taken from Ref. 3 for 1972 . This was then updated to 1976 by applying air conditioning saturation rates of new construction in the Northeast to NYS new construction data. 5

Efficiency values for energy devices were taken from the BNL report "Sourcebook for Energy Assessment." 6 For future reference years, changes in efficiencies were included as shown in Chapter III.

\subsubsection{Residential Sector Projection Basis and Data Sources}

To project residential energy and fuel demands, the following data were required:

- Estimates of the number of households for 1976 and 1985 (see Table 10)

- Breakdown according to housing types for all reference years

- Unit energy demands for major end use technologies in residential units (e.g., space heating) (see Appendix A)

- Saturation values for major end uses (see Appendix A)

- Breakdown of the fuel mix to meet end use demand (see Appendix A)

\subsubsection{Residential Fuel Mix Projections}

The procedure described below was employed to obtain projections of fuel demands in the residential sector.

- The 1976 fuel utilization breakdown was initially obtained by assuming the same fuel mix as given in the 1970 Bureau of Census Report, "Detailed Housing Characteristics, 1970."7 The values were then modified based on the fuel mix of new construction in the Northeast for the period 1970-1975.8

- The 1985 allocation of fuels to space and water heating end uses was determined by incorporating the 1985 residential market allocation of electricity as shown in Table 6 in Chapter III. 0 il and gas were allocated to the remaining energy demand in these end use areas in the same proportion as in 1976.

- New technologies were included as described in Table 5, Chapter III.

- For the remaining end use demands, allocation among fuels was based on the 1976 breakdown, with the additional restriction that the consumption of oil for cooking cannot exceed the 1976 level. 
Table 10

NYS HOUSEHOLD AND POPULATION PROJECTION

(in Thousands)

$\begin{array}{lll}\text { Households } & \frac{1976}{6,150 \pi} & \frac{1985}{6,889} \\ \text { Population } & 18,084 & 18.343\end{array}$

*Estimated using the 1976 population and 2.94 persons/household, which was calculated from historical data.

Source: New York State Economic Development Board (EDB) 9

\section{Table 11}

ANNUAL GROWTH RATES AND BASIS CHANGES FOR REFERENCE YEARS (106 Households)

\begin{tabular}{|c|c|c|c|}
\hline & 1976 & $\begin{array}{c}1976-1985 \\
A G R^{a}\end{array}$ & $\begin{array}{l}1985 \\
\text { Basis }\end{array}$ \\
\hline$\frac{\text { Subsect on }}{\text { Hiah Rise }}$ & $\frac{\text { Basis }}{1.50}$ & $\frac{A G R}{.0015}$ & $\frac{\cos 15}{1.52}$ \\
\hline Low Density & 1.46 & b & 1.44 \\
\hline Low Rise & .79 & .0207 & .95 \\
\hline Single Family & 2.31 & .0158 & 2.66 \\
\hline Mobile Homes & .09 & .1514 & .32 \\
\hline Total & 6.15 & $.012 \pi$ & 6.89 \\
\hline
\end{tabular}

annual Growth Rate

bovera11, 1.3\% fewer low density structures existed in 1985 than 1976.

\subsubsection{Housing Projections}

Housing was characterized hy five hasic types:
- Single family
one unit detached structures
- Low Density
one unit attched structure and 2 to 4 unit structures
- Low Rise structures with 5 to 19 housing units
o. High Rise structures with 20 or more units
- Mobile Homes 
The projected housing mix shown in Table 11 was obtained as follows:

1. The 1970 housing mix was obtained from the 1970 Census of Housing. The housing mix was then projected to 1976 after consideration of a number of factors, including the total number of households in. 1976 , the mix of new housing from 1970 to 1976,8 and the 1970 housing mix.

2. The 1985 housing breakdown was distributed according to the Northeast housing breakdown in the "Project Independence Task Force Report."

\subsection{THE COMMERCIAL SECTOR}

\subsubsection{High?ights}

Highlights of energy consumption for the commercial sector in each reference year are as follows:

\section{$\underline{1976}$}

- Total energy consumption: $641 \times 10^{12} \mathrm{Btu}$

- Consumes $19 \%$ of the total state energy demand

- By energy form, demands in terms of the state fuel totals are: oil $18 \%$, gas $20 \%$, electricity $33 \%$

- By energy form, demands in terms of the commercial energy total are: $0 i 157 \%$, gas $18 \%$, electricity $20 \%$, steam $5 \%$

- By end use, fuel demands as a percentage of the commercial fuel totals are:

$$
\begin{array}{lr}
\text { Space Heating steam } 100 \%, \text { oil } 100 \%, \text { gas } 62 \%, \text { electricity } 3 \% \\
\text { Water Heating gas } 37 \% \text {, electricity } 12 \% \\
\text { Air Conditioning } & \text { gas } 1 \%, \text { electricity } 15 \% \\
\text { Lighting } & \text { electricity } 43 \% \\
\text { App-Aux Equip. } & \text { electricity } 30 \%
\end{array}
$$

\section{5}

- Total energy consumption: $728 \times 10^{12} \mathrm{Btu}$

- Consumes $21 \%$ of the total state energy demand

0 By energy form, demands in terms of state fuel totals are: oil $20 \%$, gas $24 \%$, electricity $32 \%$

- Bv energy form, demands in terms of the commercial energy total are: 0 il $56 \%$, gas $18 \%$, electricity $122 \%$ 
$0 \quad$ By end use, fuel. demands as a percentage of the commercial fuel totals are:

Space Heating $011100 \%$, gas $64 \%$, electricity $11 \%$ Water Heating Air Conditioning gas $35 \%$, electricity $12 \%$

Lighting App-Aux Equip. electricity $13 \%$ electricity $37 \%$ electricity $27 \%$

- Total energy demand increases $14 \%$ over the 1976 period

- Demand for electricity increases $24 \%$ while natural gas and 0il demands increase by only $11 \%$ and $11 \%$ respectively, from 1976 .

- The relative differences in growth rates between electricity and fossil fuel demands arises from a slight shift to electric technologies for space and water heating from oil and gas technologies.

- Approximately $1 \%$ of the space heating demand is met by the use of heat pumps

- Solar provides less than $1 \%$ of the water heating requirements

Eneray demands for each reference year are summarized in Appendix A. Fuel requirements for this sector are compared in Figure 11.

\subsubsection{Commercial Sector Unit Demands, Saturation and Efficiencies}

The commerclal sector Includes structures that serve such diverse activities as wholesale and retail trade, services (finance, insurance, etc.), schools and hospitals.

The following input is required to project the energy demand in each of these categories.

- The square footage of each activity listed above for both reference years.

o The unit energy demands for major end uses (space and water heating etc.) for each activity in terms of Btu/sq. ft.

- Saturation values for the major end uses and efficiency values of each technology.

- The fuel breakdown. for each end use. 


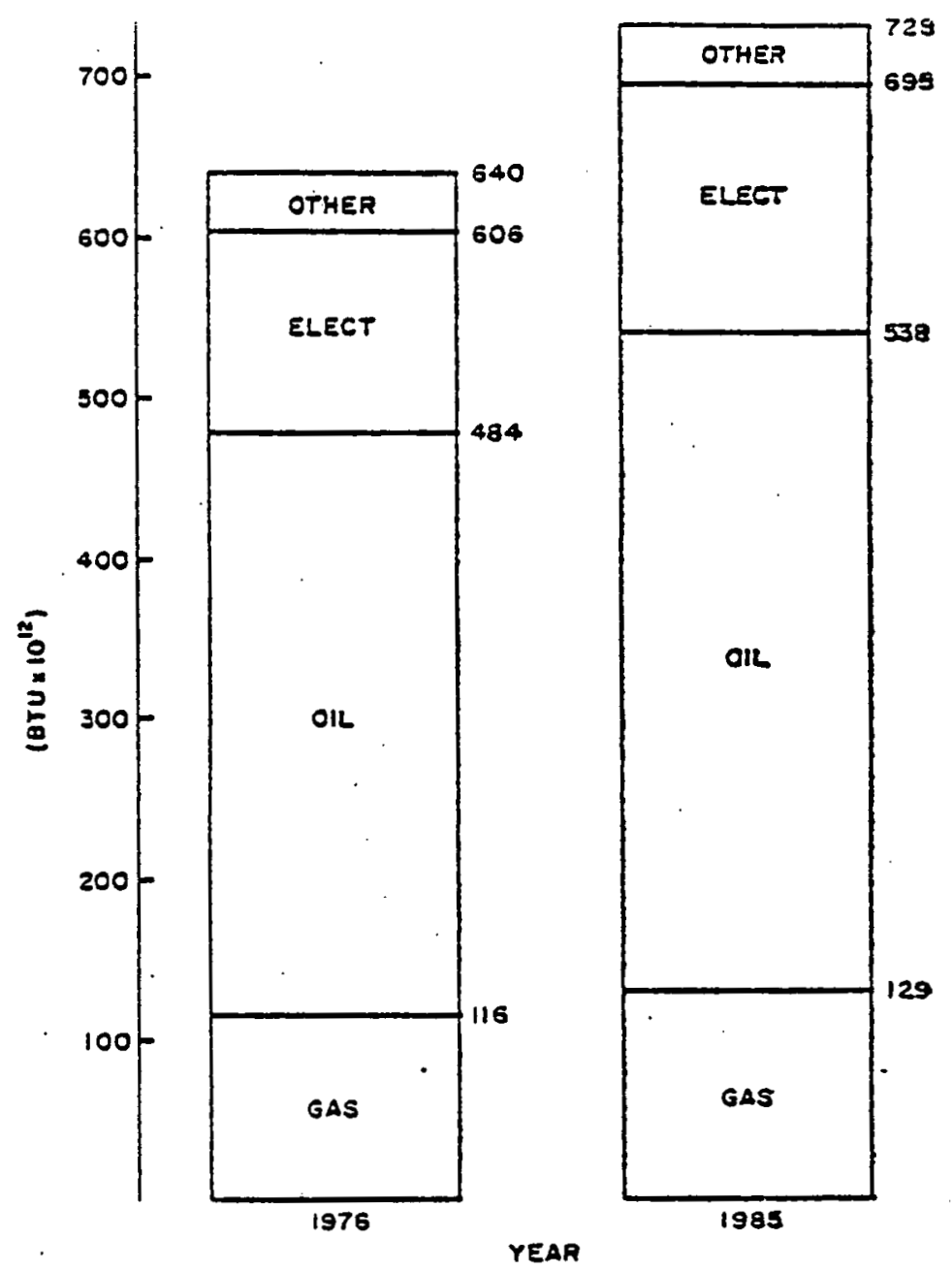

Figure 11. NYS COMMERCIAL SECTOR ENERGY DEMANDS.

\subsubsection{Commercial Sector Projection Basis and Data Sources}

Determination of floorspace in this sector for New York State was difficult as little data has been published at the level of disaggregation required.. Floor space for 1974 provided in reference 10 was used as a starting point for further analysis. In that reference, Northeast data, obtained from Reference 1 was regionalized to New York State. Growth rates estimated in Reference 10 were used to obtain 1976 floorspace. These growth rates were then compared with other sources to test their reliability.* Hospital floorspace for 1976 was received from the N.Y.S. Department of Health and included floorspace of each hospital as reported by that hospital. However, the data were incomplete and the reporting procedure used by the hospitals were found to be inconsistent. Therefore, the floorspace for hospitals was taken from Reference 10.

*The combined floorspace of offices, retail establishments, and services were projected to increase at a rate of 2.4\% during the 1974 to 1976 period. The number of business establishments included in these categories increased by 1.3\% during the same period.14 Employment in these categories actually dropped 1\% during this period. 
School floorspace for 1976 was obtained as follows:

1. College floorspace for 1976 was obtained from the N.Y.S. Dept. of Education, Post Secondary Education 11

2. Enrollment in 1976 for grades $K-12$ was obtained from the N.Y.S. Department of Education. 12 The enrollment figures were multiplied by a factor of $120 \mathrm{sq}$. ft. per student. 10

3. College floorspace and estimated pre-college floorspace were summed to determine the total 1976 school floorspace.

Two parameters must be considered in calculating the 1985 commercial floorspace, the new commercial floorspace during the projection period as well as the removals of old structures. The 1985 floorspace for each subsector was obtained using the following procedures:

1. Offices, Retail and Services: Earning projections for each of these subsectors were used to determine their new floorspace. These projections for New York State were obtained from the U.S. Department of Commerce and were the latest revisions of the "1972 OBER's Projections: Economic Activity in the U.S."13 Forecasting removals from the commercial inventory is very difficult because of the lack of data on current and historical removal rates and on the age distribution of the structures. This report uses the removal rates described in Reference 1 for the Northeast, which were assumed to be the same as their projected residential removal rates.

2. Schools and Hospitals: The overall change in floorspace for each of these subsectors was assumed to be the same as those given in Reference 10 after a review of the described procedures and data sources. Implicit assumptions were made in that report that total removals will equal total constructions in each of these subsectors.

The 1976 and 1985 commercial inventory is presented in Table 12.

Table 12

COMMERCIAL FLOORSPACE INVENTORY

$$
\left(10^{6} \text { sq. ft. }\right)
$$

\begin{tabular}{|c|c|c|c|c|c|}
\hline Subsector & $\begin{array}{l}1976 \\
\text { Basis }\end{array}$ & $\begin{array}{c}1976-1985 \\
\text { Constructions } \\
\end{array}$ & $\begin{array}{r}1976-1985 \\
\text { Removals } \\
\end{array}$ & $\begin{array}{l}1985 \\
\text { Basis } \\
\end{array}$ & $\begin{array}{c}1976-1985 \\
\text { AGR D } \\
\end{array}$ \\
\hline $\begin{array}{l}\text { School } \\
\text { Huspital } \\
\text { Office } \\
\text { Retail } \\
\text { Services }\end{array}$ & $\begin{array}{l}653.10 \\
208.70 \\
464.20 \\
523.50 \\
800.60\end{array}$ & $\begin{array}{c}\mathrm{a} \\
\mathrm{d} \\
144.30 \\
99.60 \\
341.10 \\
\end{array}$ & $\begin{array}{c}a \\
a \\
49.30 \\
42.40 \\
64.90 \\
\end{array}$ & $\begin{array}{r}653.10 \\
208.70 \\
559.20 \\
580.70 \\
1076.80 \\
\end{array}$ & $\begin{array}{l}.0 \\
.0 \\
.0209 \\
.0116 \\
.0335 \\
\end{array}$ \\
\hline Total & 2650.10 & 585.00 & 156.60 & 3078.50 & .0168 \\
\hline
\end{tabular}

aRemovals and constructions for schools and hospitals are assumed to be equal. bannual growth rate. 


\subsection{THE MANUFACTURING SECTOR}

\subsubsection{Highlights}

Highlights of the energy consumption for the manufacturing sector in each reference year are as follows:

\section{6}

- Total energy consumption: $646 \times 10^{12} \mathrm{Btu}$

- Consumes $19 \%$ of the total state energy demand

- The five largest energy consumers in the manufacturing sector are (in decreasing order):

$\begin{array}{ll}\text { Chemical and allied products, } & \text { SIC } 28 \\ \text { Primary metal industries, } & \text { SIC } 33 \\ \text { Paper and allied products, } & \text { SIC } 26 \\ \text { Stone, clay and glass products, } & \text { SIC } 32 \\ \text { Food and kindred products, } & \text { SIC } 20\end{array}$

- By energy form, the industrial fuel demands as a percentage of the state fuel totals are: $0116 \%$, gas $16 \%$, coal (including coking coal) $100 \%$, P.C.F. (Petrochemical feedstocks) $100 \%$, electricity $30 \%$

- By energy form, demands as a percentage of the industrial energy total are: oil 19\%, P.C.F. $20 \%$, gas $14 \%$, coal $30 \%$, electricity $17 \%$

- Coking coal to the primary metal industries (SIC 33) constituted $66 \%$ of the industrial coal demand

\section{5}

- Total energy consumption: $702 \times 10^{12} \mathrm{Btu}$

- Consumes $20 \%$ of the total state energy demand

- By energy form, demands as a percentage of the states fuel totals are: oil 7\%, gas 14\%, coal 100\%, P.C.F. 19\%, electricity $17 \%$

- By energy form, demands as a percentage of the industrial energy total are: oil 18\%, gas 10\%, coal 33\%, P.C.F. 19\%, electricity $17 \%$

- Coking coal to SIC 33 constituted $66 \%$ of the industrial coal demand

n Total industrial energy demand increases by $9 \%$ from 1976

- Coal demand increases by $19 \%$ primarily because of an increase in the demand for coking coal

- Gas demand decreases by $17 \%$ from 1976, while electricity demand increases $7 \%$ 
- $0 i 1$ and petrochemical demands increase by $18 \%$ and $5 \%$, respectively from 1976

- The changes in fuel demand from 1976 for the industrial sectors major users of energy are:

$\begin{array}{lll}\text { SIC } 28 & \text { (Chemical and allied products) } & +5 \% \\ \text { SIC } 33 & \text { (Primary metal industries) } & +11 \% \\ \text { SIC } 26 & \text { (Paper and Al1 ied products) } & +11 \% \\ \text { SIC } 32 & \text { (Stone, clay and glass products) } & +6 \% \\ \text { SIC } 20 & \text { (Food and kindred products) } & +20 \%\end{array}$

Energy demands in each reference year are summarized in Appendix A. A comparison of energy demands in this sector is provided in Figure 12.

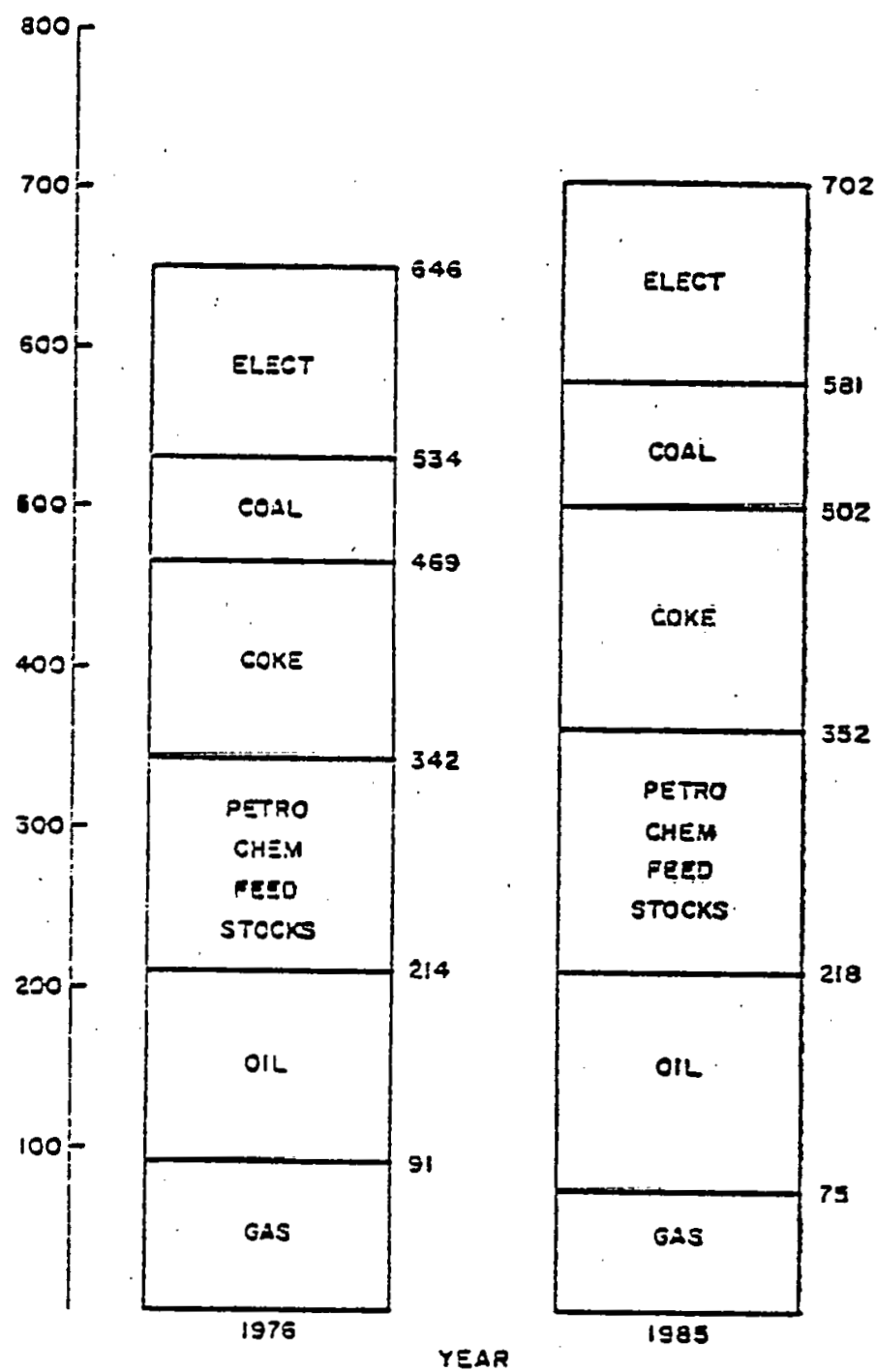

Figure 12. NYS MANUFACTURING SECTOR ENERGY DEMAND. 


\subsubsection{Industrial Sector Projection Basis and Data Sources}

The energy intensiveness of each industrial subsector is represented by the ratio, Btu/dollar-value-added. Value added by two digit Standard Industrial Category was obtained from Reference 15. Fuel consumption by two digit SIC for 1976 was obtained from the 1976 Annual Survey of Manufacturers: Fuels and Electric Energy Consumed. 16

Coking coal consumption in N.Y. was taken from a Mineral Industry Survey, "Bituminous Coal and Lignite Distribution, Calendar Year 1976."28 Data on petrochemical consumption in N.Y. for 1976 was diffcult to obtain. The 1972 consumption of petrochemical feedstocks was taken from BNL-50555 "Alternative Patterns of Industrial Energy Consumption in the Northeast," 18 and projected to 1976 on the basis of real dollar added growth in SIC 28 for the period 1972-1976. Total fuel consumption by SIC is shown in Table 13.

\subsubsection{Industrial Fuel Mix Projections}

Three factors were considered in projecting the industrial fuel mix, including estimates of value added in 1985, changes in the efficiency of industrial processes and fuel substitution. The following paragraphs describe the methodology employed in calculating the 1985 value added by SIC category and the combined role of all three factors noted above.

The procedure used in calculating the 1985 value added was taken from Reference 18. A constant national ratio of Gross Product Originating (GPO) to earnings was obtained from the 1972 OBERS for each two digit SIC for 1976* and 1985. The 1976 New York State GPO was calculated for each SIC by multiplying the New York State 1976 earnings for each SIC (from Reference 18) by the national GPO/earnings ratio. The 1985 GPO was calculated by multiplying the 1985 GPO/earnings ratio by the projected 1985 earnings for each SIC, also taken from Reference 18. Growth rates for each SIC were determined by calculating the percentage differences from the 1977 and 1985 GPO values. These growth rates were then applied to the 1.976 value added by SIC.

The 1985 fuel demands were then calculated for each SIC by using the 1976 energy intensiveness coefficient, the 1985 valve added, and including the efficiency and fuel demand changes described in Chapter III. Projected fuel demands for the major industrial users are shown in Table 14. The fuel breakdown in the industrial sector for each reference year is shown in Table 15.

*The 1976 GPO/earnings was extrapolated from 1972 and 1980 values. 
Table 13

INDUSTRIAL SUBSECTORS ORDERED BY 1976 ENERGY CONSUMPTION

\begin{tabular}{|c|c|c|c|}
\hline rder & SIC & Description & $\begin{array}{c}\left(10^{12} \mathrm{Btu}\right) \\
\text { Energy Demand }\end{array}$ \\
\hline 1 & 28 & Chemical and allied products & 192.3 \\
\hline 2 & 33 & Primary metal industries & 190.2 \\
\hline 3 & 26 & Paper and allied products & 45.9 \\
\hline 4 & 32 & Stone, clay and glass products & 38.5 \\
\hline 5 & 20 & Food and kindred products & $\begin{array}{l}34.3 \\
23.9\end{array}$ \\
\hline 6 & 36 & Electrical equipment supplies & $\begin{array}{l}23.9 \\
23.8\end{array}$ \\
\hline 7 & 35 & Machinery, except electrical & \\
\hline 8 & 37 & Transportation equipment & 15.9 \\
\hline 9 & 38 & Instruments and related products & 15.3 \\
\hline 10 & 34 & Fabricated metal products & 15.1 \\
\hline 11 & 27 & Printing and publishing & 12.9 \\
\hline 12 & 30 & Rubber and olastic products & 9.1 \\
\hline 13 & 22 & Textile mill products & 7.7 \\
\hline 14 & 23 & Apparel and other fabric products & 6.5 \\
\hline 15 & 39 & Misc. manufacturing industries & 6.0 \\
\hline 16 & 31 & Leather and leather products & 3.0 \\
\hline 17 & 25 & Furniture and fixtures & 6.6 \\
\hline 18 & 20 & Lumber and wood products & $\frac{2.2}{544.3}$ \\
\hline
\end{tabular}

Table 14

MAJOR INDUSTRIAL ENERGY USERS: TOTAL FUEL DEMAND (Btu $\times 10^{12}$ and $\%$ of Total Industrial Demand)

\begin{tabular}{llrr} 
SIC & Chemical and allied products & $193(29.9 \%)$ & $202 \frac{1985}{(28.8 \%)}$ \\
\hline 28 & Primary metal industries & $190(29.3 \%)$ & $211(30.1 \%)$ \\
33 & Paper and allied products & $46(7.1 \%)$ & $51(7.3 \%)$ \\
26 & Stone, clay and glass products & $39(6.0 \%)$ & $41(5.8 \%)$ \\
32 & Food and kindred products & $32(5.0 \%)$ & $41(5.8 \%)$
\end{tabular}

Table 15

INDUSTRIAL ENERGY DEMAND BY FUEL TYPE

(\% and Btu $\times 10^{12}$ )

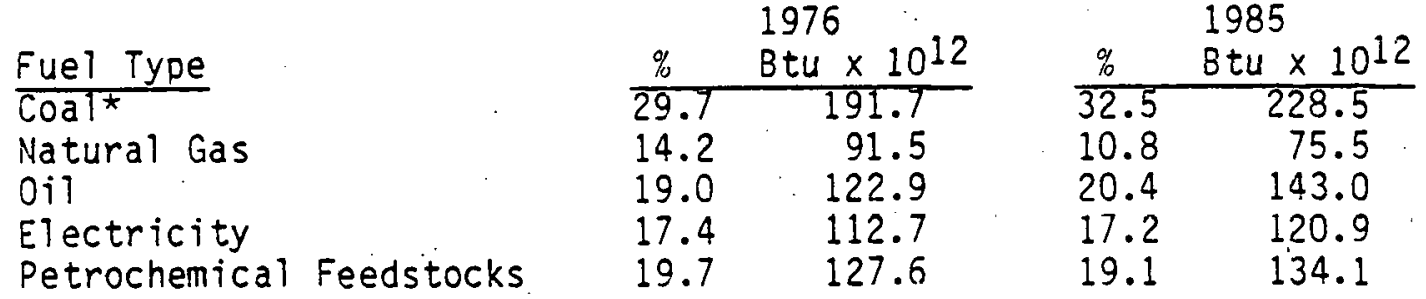

त्रcludes coking coal. 


\subsection{THE TRANSPORTATION SECTOR}

\subsubsection{Highlights}

Highlights of energy consumption for the transportation sector in each reference year are as follows: :

\section{$\underline{1976}$}

- Total energy consumption: $1016 \times 10^{12} \mathrm{Btu}$

- Consumes $32 \%$ of the total state energy demand

- By energy form, demands in terms of the state fuel totals are: oil $52 \%$, electricity $2 \%$

- By energy form, demands as a percentage of the transportation energy total are: oil $98 \%$, electricity $2 \%$

- By mode, energy demands as a percentage of the total transportation energy consumption are:

$\begin{array}{lr}\text { Automobile } & 54 \% \\ \text { Truck } & 16 \% \\ \text { Air Pass } & 13 \% \\ \text { Air Freight } & 5 \% \\ \text { Water Freight } & 5 \% \\ \text { Rail } & 2 \%\end{array}$

\section{5}

- Total energy consumption: $1011 \times 10^{12}$ Btu

- Consumes $29 \%$ of the total state energy demand

$0 \quad$ By energy form, demands in terms of state fuels totals are: oil $49 \%$, electricity $2 \%$

- By energy form, demands as a percentage of the transportation energy total are: 0 i $99 \%$, electricity $1 \%$

- By mode, energy demands as a percentage of the total transportation energy consumption are:

$\begin{array}{lr}\text { Automobile } & 46 \% \\ \text { Air Pass } & 19 \% \\ \text { Truck } & 16 \% \\ \text { Air Freight } & 8 \% \\ \text { Water Freight } & 7 \% \\ \text { Rall } & 3 \%\end{array}$

- Total transportation energy demand decreases by less than $1 \%$ from 1976

- Automobile energy demand decreases by $21 \%$ from 1976 , a consequence of increased fuel efficiency and a slow growth in vehicle miles travelled during the pertod 
0 The air subsectors energy demand increases by $37 \%$ (despite decreased unit demands) due to a large increase in service

Details of reference year fuel demand by end use are presented in Appendix $A$.

\subsubsection{Transportation Sector Projection Basis and Data Sources}

Total motor vehicle oil consumption in New York State for 1976 was obtained from the U.S. Federal Highway Administration (F.H.A.).19 This aggregate consumption figure was apportioned among three motor vehicle subsectors (buses, trucks, and automobiles) reflecting their vehicle miles traveled (VMT) and mileage per gallon (MPG). The VMT and MPG estimates were obtained from Highway Statistics, $1975^{20}$ and the Mew York State Department of Transportation.

Bunker fuel consumption by water freight carriers was obtained from Reference 22 as was the consumption by the rail subsectors. Electricity consumed by railroads in the state was taken from a New York Power Pool Report.23 Consumption by the air subsector was obtained from the Air Transport Association. 24

Unit demands were obtained from a previous study by system Designs, Inc. 25 Modification were made based on more recent information. For example, the automobile unit demand reflects a different miles per aallon value than that uscd by Systems Design, Inc.

Ton miles for freight carriers and passenger miles for passenger carriers were calculated for each subsector using the unit demand and fuel consumption values.

\subsubsection{Transportation Fuel Projections}

The 1976 to 1985 growth rate in VMT for automobiles was based on a study by the New York State Department of Transportation. 21 The average passenger load per vehicle was kept at the 1976 level to ealculate the 1985 automobile passenger miles travelled. Ton-mile and passenger-mile values for the remaining subsectors were calculated by using the procedure described in Reference 10, but included the latest data available. Data for the air subsectors were modified according to Reference 24. The new OBER's projections were used in the basis projections for the rail, water, truck and bus subsectors. The 1975 and 1985 basis values are presented in Table 16. Efficiency and unit demands were modified to conform with the projection assumptions described in Chapter III. 
Table 16

ANNUAL GROWTH RATES AND BASIS CHANGES FOR REFERENCE YEARS

(106 passenger miles for passenger transport and $10^{6}$ ton miles for freight transport)

\begin{tabular}{|c|c|c|c|}
\hline $\begin{array}{l}\text { Subsector } \\
\text { Air-Pass } \\
\text { Air-Freight } \\
\text { Auto } \\
\text { Bus } \\
\text { Rail-Pass } \\
\text { Rail-Freight } \\
\text { Truck } \\
\text { Water Freight }\end{array}$ & $\begin{array}{r}1976 \\
\text { Basis } \\
9,046 \\
1,348 \\
89,680 \\
838 \\
8,472 \\
21,525 \\
40,692 \\
81,694\end{array}$ & $\begin{array}{c}1976-1985 \\
\text { AGR }\end{array}$ & $\begin{array}{r}1985 \\
\text { Basis } \\
12,876 \\
2,091 \\
96,425 \\
950 \\
9,467 \\
25,499 \\
45,389 \\
102,740\end{array}$ \\
\hline
\end{tabular}

*Annual Growth Rate

Table 17

TRANSPORTATION FUEL DEMAND

$\left(\right.$ Btu $\left.\times 10^{12}\right)$

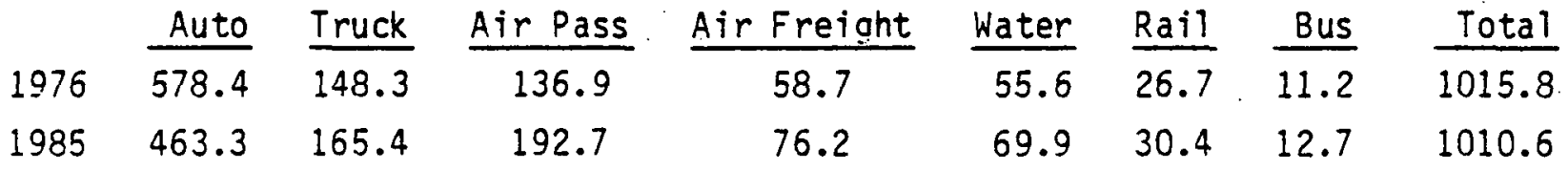

Table 18

SUMMARY OF TRANSPORTATION ENERGY DEMANDS

(Btu $\times 10^{12}$ )

\begin{tabular}{|c|c|c|c|}
\hline $\begin{array}{l}\frac{1976}{\text { Freight }} \\
\text { Passenger }\end{array}$ & $\begin{array}{c}011 \\
278.4 \\
729.1 \\
\end{array}$ & $\frac{\text { Electricity }}{\underline{.2}}$ & $\begin{array}{l}\text { Total } \\
278.6 \\
737.2 \\
\end{array}$ \\
\hline Total & 1007.5 & 8.3 & 1015.8 \\
\hline $\begin{array}{l}\frac{1985}{\text { Freight }} \\
\text { Passenger }\end{array}$ & $\begin{array}{l}330.4 \\
671.4 \\
\end{array}$ & $\begin{array}{r}.2 \\
8.6 \\
\end{array}$ & $\begin{array}{l}330.6 \\
680.0 \\
\end{array}$ \\
\hline Total & 1001.8 & 8.8 & 1010.6 \\
\hline
\end{tabular}


Table 17 summarizes transportation demand by subsector and reference year. The 1976 and 1985 fuel mix is presented in Table 18.

\subsection{GOVERNMENT}

\subsubsection{Highlights}

Highlights of energy consumption for the government sector in each reference year are as follows:

\section{6}

- Total energy consumption: $11 \times 10^{12} \mathrm{Btu}$

- Consumes less than $1 / 2 \%$ of the total state energy demand

- By energy form, demands as a percentage of the government energy total are: oil $81 \%$, gas $9 \notin$, electricity $7 \%$

$0 \quad$ By end use, fuel demands as a percentage of the government fuel totals are:

$\begin{array}{lll}\text { Auto } & 0 i 162 \% & \\ \text { Space Heating } & 0 i 138 \%, \text { gas } 70 \%, & \text { electricity } 0 \% \\ \text { Water Heating } & & \text { electricity } 12 \% \\ \text { Lighting } & \text { electricity } 40 \% \\ \text { App-Aux. Equip. } & \text { electricity } 25 \% \\ \text { Air conditioning } & \text { electricity } 23 \%\end{array}$

\section{$\underline{1985}$}

- Total energy consumption: $10 \times 1012 \mathrm{Btu}$

- Consumes less than $1 / 2 \%$ of the total state energy demand

- By energy form, demands as a percentage of the government energy total are: 0 il $78 \%$, gas $9 \%$, electricity $10 \%$

$0 \quad$ By end use, the fuel demands as a percentage of the government fuel totals are:

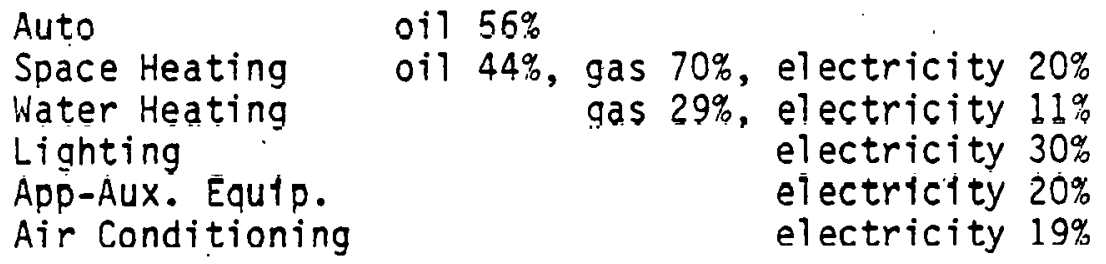

- Total energy demand decreases 13\% from 1976 to 1985

- Electrical demand increases $19 \%$ over 1976 because of a shift in space heating technologies from gas and $0 i 1$ to electricity

- Automobile demand decreases by $24 \%$, brought about mainly by a decrease in auto unit demand

- $\quad 0 i 1$ and gas demands decrease by $16 \%$ and $11 \%$ respectively from 1976 
Government fuel demands for each reference year are summarized in Appendix A.

\subsubsection{Government Projection Basis and Data Sources}

Government offices and auto fleets are the primary energy consuming units in the government sector. Floorspace was selected as the projection variable for government offices and vehicle miles travelled (VMT) for the government auto fleet. State office space data was obtained from the N.Y.S. Bureau of Space Planning. 26 The number of government automobiles in the state was taken from Reference 20 and the averge yearly mileage from the N.Y.S. Office of General Services. 27 Note that the government auto fleet includes automobiles from all levels of government, not just the state government. The average annual mileage was applied to all government automobiles.

Unit demands, efficiencies and the technology breakdown for office energy use were assumed to be the same as for the commercial sector office energy use. The efficiencies of government automobiles were assumed to be the same as for automobiles in the transportation sector. Government auto fuel consumption was calculated by dividing the total government VMT by the state average miles per gallon figure provided by Reference 27 . The government auto unit demand was then calculated from these data.

\subsubsection{Government Fuel Mix Projections}

Office space and vehicle miles travelled were projected to 1985 on the basis of the 1976-1985 state population growth. Population projections were available from the NYS EDB. Growth rates and the projected floorspace and vehicle miles for 1985 are shown in Table 19.

. Changes in efficiencies and unit demands, as described in Chapter III are incorporated into the 1985 fuel projections.

Table 19

ANNUAL GROWTH RATES AND BASIS CHANGES FOR REFERENCE YEARS

\begin{tabular}{|c|c|c|c|}
\hline $\begin{array}{l}\text { Subsector } \\
\text { offices } \\
\left(10^{6} \text { sq. ft.) }\right.\end{array}$ & $\begin{array}{l}1976 \\
\text { Basis } \\
16.65\end{array}$ & $\begin{array}{c}1976-1985 \\
\text { AGR } \\
.0014\end{array}$ & $\begin{array}{l}1985 \\
\text { Basis } \\
16.86\end{array}$ \\
\hline $\begin{array}{l}\text { Pass. Trans. } \\
\text { (106 Vehicle Miles) }\end{array}$ & 573.44 & .0014 & 580.83 \\
\hline
\end{tabular}




\subsection{THE AGRICULTURAL SECTOR}

\subsubsection{Highlights}

Agricultural sector highlights for the two reference years are:

\section{6}

- Total energy consumption: $14.0 \times 10^{12} \mathrm{Btu}$

- Accounts for less than $1 \%$ of the state's energy consumption

- Obtains $87 \%$ of its energy from oil and $13 \%$ from electricity

\section{5}

o Total energy consumption: $12.4 \times 10^{12} \mathrm{Btu}$

- Accounts for less than $1 \%$ of the state's energy consumption

o Obtains $87 \%$ of its energy from oil and $13 \%$ from electricity

- Electricity demand decreases by $11 \%$, 011 demand decreases by $11 \%$ (from 1976)

Table 20 summarizes agricultural fuel demands for the two reference years.

Table 20

SUMMARY OF ENERGY USE IN THE AGRICULTURAL SECTOR $\left(\right.$ Btu $\left.\times 10^{9}\right)$

\begin{tabular}{|c|c|c|c|}
\hline $\begin{array}{l}1976 \\
\text { All Crops } \\
\text { All Stock } \\
\text { Electricity } \\
\text { Propane } \\
\text { Total }\end{array}$ & $\begin{array}{r}011 \\
9,435.0 \\
1,780.7 \\
\quad 973.5 \\
12,189.2\end{array}$ & $\frac{1,781.2}{1,781.2}$ & $\begin{array}{l}\text { Total } \\
\text { O1rect Use } \\
\begin{array}{r}9,435.0 \\
1,780.7 \\
1,781.2 \\
973.5 \\
13,970.4\end{array}\end{array}$ \\
\hline $\begin{array}{l}\frac{1985}{\text { Al Crops }} \\
\text { Al1 Stock } \\
\text { Electricity } \\
\text { Propane } \\
\text { Total }\end{array}$ & $\begin{array}{r}\frac{011}{8,351.1} \\
1,576.2 \\
\\
861.7 \\
10.789 .0\end{array}$ & $\begin{array}{c}\text { Electricity } \\
1,576.7\end{array}$ & $\begin{array}{l}\text { Total } \\
\text { Direct Use } \\
8,351.1 \\
1,576.2 \\
1,576.7 \\
\frac{861.7}{12,365.7}\end{array}$ \\
\hline
\end{tabular}


4.6.2 Agricultural Projection Basis, Data Sources and Fuel Mix

For the agricultural sector, the most convenient parameters of energy demand are number of farms, acres harvested by kind of crop and heads of livestock. Information on these for 1976 has been provided by Reference 28 and 29.

A complete breakdown of the agricultural subsectors by end uses would require data that are at the present time unavailable. Thus it was decided to define an aggregate end use for each subsector which would encompass all the uses for that subsector. For crops, for example, the end use would include tilling, planting, cultivating, harvesting, drying, etc., for the livestock subsector it would include, among other uses, heating barns and cleaning milk machines. Fuel consumption patterns. will reflect composition of the basis and the choice of technologies employed. For this study, technologies have been specified by the type of fuel using average efficiencies of typical devices which use that fuel.

Projections of energy demands for this sector were derived from 1975 OBERS projections for New York State, using projected total earnings from 1976 and 1985. The earnings yield a 8.3 decrease in income from 1976 to 1985.

Projected energy demands for the agricultural sector in 1976 and 1985 are presented in Appendix $A$. 
1. J. Lee, "Future Residential and Commercial Energy Demand in the Northeast," BNL 50552 (March 1976). Brookhaven National Laboratory, Upton, New York.

2. T. Tansil, "Residential Consumption of Electricity, 1950-70,". (July 1973), Oak Ridge National Laboratory, Oak Ridge, Tennessee.

3. Arthur 0 . Little, Inc., "Project Independence Task Force Report: Residential and Commercial Energy Use Patterns, 1970-1990," prepared for the Federal Energy Administration, Washington, D.C. (1974).

4. Arthur D. Little, Inc. Latest revisions of unit demands in Reference 3 (unpublished).

5. NYS Uivision of the Budget, NYS Statistical Yearbook 1977, Albany, New York.

6. M. Beller, "Sourcebook for Energy Assessment," BNL-50483 (December 1975), Brookhaven National Laboratory, Upton, New York.

7. U.S. Department of Commerce, Bureau of the Census, "Detailed Housing Characteristics, 1970: New York State," Washington, DC (1972).

8. U.S. Department of Commerce, Bureau of the Census, "Characteristics of New Housing, Construction Reports," Washington DC (1976).

9. NYS Economic Development Board, "Official Household Projections for New York State Counties, 1978" and "Official Population Projections for New York State Counties, 1978," Albany, N.Y.

10. J. Allentuck et. al., "An Assessment of Energy Research, Development and Demonstration Priorities for New York State," BNL-50733 (November 1977), Brookhaven National Laboratory, Upton, New York.

11. Phone conversation with Mr. Luce, NYS Department of Education, Post Secondary Schools, April, 1978.

12. Phone conversation with staff members, NYS Department of Education, Facilities Planning, April, 1978.

13. U.S. Departments of Commerce and Agriculture, "1972 OBERS Projections: Economic Activity in the U.S.," Vols. 1 and 4, washington, D.C. (1974) and 1 atest modifications (unpublished).

14. NYS Department of Commerce, Business Fact Book: 1974 and 1976 editions, Aibany, New York.

15. U.S. Department of Commerce, Bureau of the Census, Annual Survey of Manufacturers, Washington, D.C., (1976).

16. U.S. Department of Commerce, Bureau of the Census, Annual Survey of Manufacturers, Fuels and Electrical Energy Conserved. Washington, D.C. (1976).

17. U.S. Bureau of Mines, Division of Fossil Fuels, "Bituminous Coal and Lignite Distribution, calendar year 1974," Washington, D.C. (Apri1 1975).

19. R. Goettle, Alternative Patterns of Industrial Energy Consumption in the Northeast," BNL-50555 (March 1976) Brookhaven National Laboratory, Upton, New York. 
19. Communication with Federal Highway Administration, May 1978.

20. U.S. Department of Transportation, "Highway Statistics, 1975" Federal Highway Administration, Washington, D.C.

21. D. Gooding, "Automotive Energy Use: A Baseline Projection for New York State," August 1977, New York State DOT, Albany, N.Y.

22. U.S. Department of Energy, "Energy Data Reports, Sales of Fuel $0 i 1$ and Kerosene, 1976," Washington, D.C.

23. New York Power Pool, "Report to Member Electric Systems of the NYPP Pursuant to Article VIII, Section 149-6 of the Public Service Law - 1978, Vol. 1."

24. Air Transport Association, "Domestic Industry Passenger Demand Forecast, 1974-2000," June 1975, and "International Air Travel Industry Passenger Demand Forecast, U.S. - Related Traffic, 1976-2000," May 1976, Washington, D.C.

25. Systems Designs Concepts, Inc., "Transportation Energy Consumption and Conservation Policy Options in the Northeast," BNL 50544, Brookhaven National Laboratory, Upton, N.Y., April 1976.

26. Telephone interview with Mr. Ray Tesiero of the NYS Bureau of Space Planning (June 1978).

27. Telephone interview with Mr. Whatan of the NYS Office of General. Services (June 1978).

28. Telephone interview with staff of the Farm Bureau, NYS Department of Agriculture and Markets (June 1978).

29. Cornell University, Agricultural Engineering Bulletin 405 (July 1976). 
THIS PAGE

\section{WAS INTENTIONALLY LEFT BLANK}




\section{CHAPTER V}

\section{COUNTY LEVEL ENERGY SUPPLY AND DEMAND}

\subsection{INTROOUCTION}

We discuss in this section the structure of the county data base, its data and data sources. While significant differences in structure do occur between fuel types because of differences in the characteristics of the fuel, variations in consumption patterns and differences in the data available, there are basic structural elements common to all energy forms. These we discuss below.

The basic structural elements common to all energy forms in the county base are show in Figure 13. For each energy form the state is divided into utility regions consisting of a number of counties. Energy is transported into the utility region, by trucks, barges, pipelines or transmission lines or produced within the region. This activity is shown in Figure 13 on the supply side of the diagram.

Within each county in a region, activities take place which require the use of energy. There is a demand for energy in the various consuming sectors - residential, commercial, industrial, transportation, electric utilities, etc. This demand by consuming sector is represented on the demand side of Figure 13.

A typical tree structure for the New York State County Data Base is shown in Figure 14. The structures have the capability of including more information than is necessary or possible to obtain for any particular energy form. For example, information for coal would not be found under power plants, capacity, or typical bills. These categories would be used only for electricity.

For electric and gas utilities regions correspond to the actual service areas of utilities providing these energy forms. For other fuels utility regions are fictitious but useful entities.

\subsection{SPECIFIC STRUCTURES}

In the paragraphs which follow we briefly describe the structure used for each of the fuel forms. A more detailed description of the data sources and the type of data available appears in Chapter IV. 


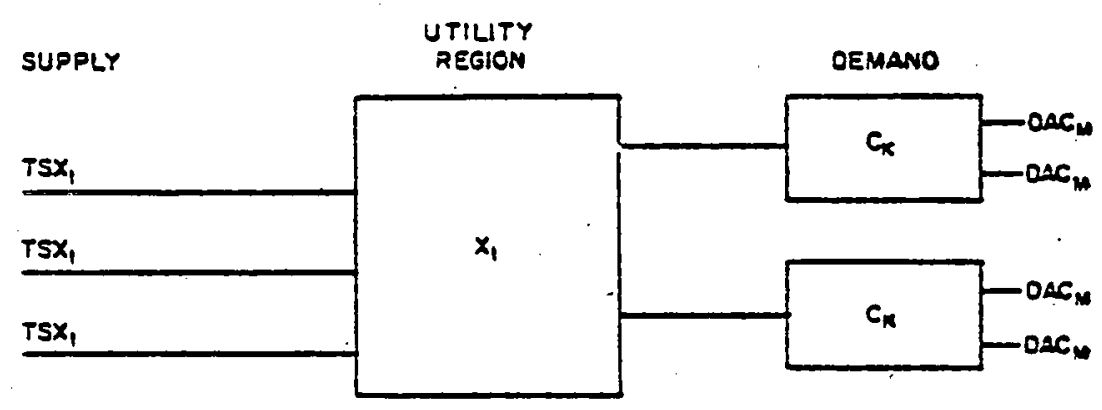

WHERE: $\quad x_{1}=$ UTILITY REGION I IN NEW YORK STATE

TSX, = QUANTITY SUPPLIEO BY MODE 5 TO UTILITY REGION I $\left(X_{i}\right)$

$C_{X}=$ COUNTYK

OAC $_{M}=$ ENERGY OEMANO IN COUNTY $K$ OY CONSUMING SECTOR $M$

Figure 13. COUNTY OATA BASE STRUCTURAL ELEMENTS.

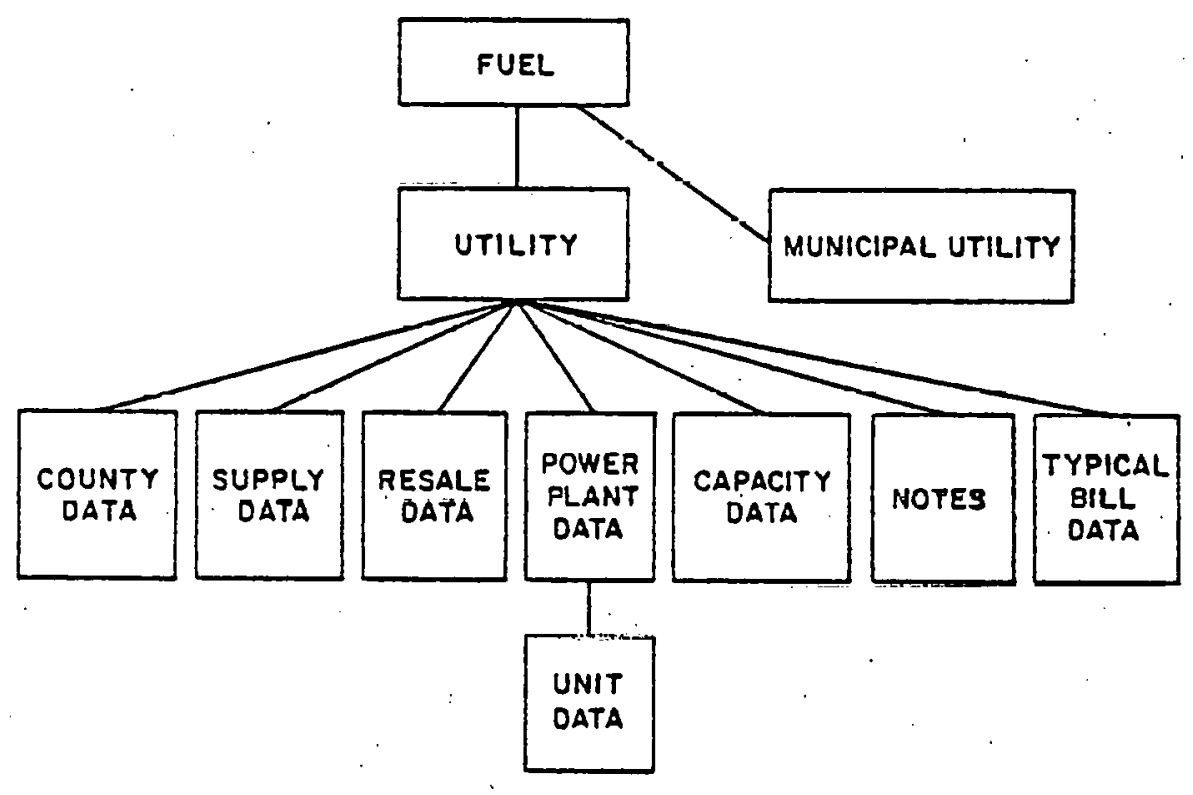

Figure 14. TREE STRUCTURE FOR NEW YORK STATE COUNTY DATA BASE. $-66-$ 


\subsubsection{Natural Gas}

The structure for natural gas is presented in Figure 15. Gas can be supplied to a utility region through one of the following supply modes:

Pipeline- Gas purchased from the national pipeline companies, and is transported to a utility region via the companies pipeline network.

Production- Synthetic gas purchased or produced by a utility

Utility- Gas purchased from another gas utility

Other- Gas supplied from miscellaneous sources, such as a private well owned by a utility.

There are 15 gas utilities in the state each supplying a utility region. A county which is supplied by more than one gas utility is included as part of each utility region. Utility regions can overlap. Thus, Queens County which is supplied by both Lilco and Con Ed, is included in both the Lilco and Con Ed utility regions.

Information that is not available at the county levels but is deemed important enough to be included in the data base, is available for a utility region. These data inciude:

Internal Use- Gas used by a utility for its own requirements

Quantity Stored- Storage space available to a utility

Quantity Lost- Gas lost or unaccounted for due to faults in the distribution network

CI Firm- Commercial/Industrial Firm. Contracts to commercial/industrial customers that cannot be interrupted because of a gas shortage.

CI Interruptible-Cormercial/Industrial Interruptible Contracts to conmercial/industrial customers that allow a utility to interrupt supply to these customers because of a gas shortage.

Sales for Resale-Sales to other utilities

Cost Data- Average cost to residential, commercial/industrial, and public authority customers

The demand sectors include sales to:

Residential customers

Commercial/Industrial customers

Public Authorities

The unit of measure for natural gas supply/demand data is Mcf-thousand cubic feet. The unit of measure for cost data is s/Mcf. 


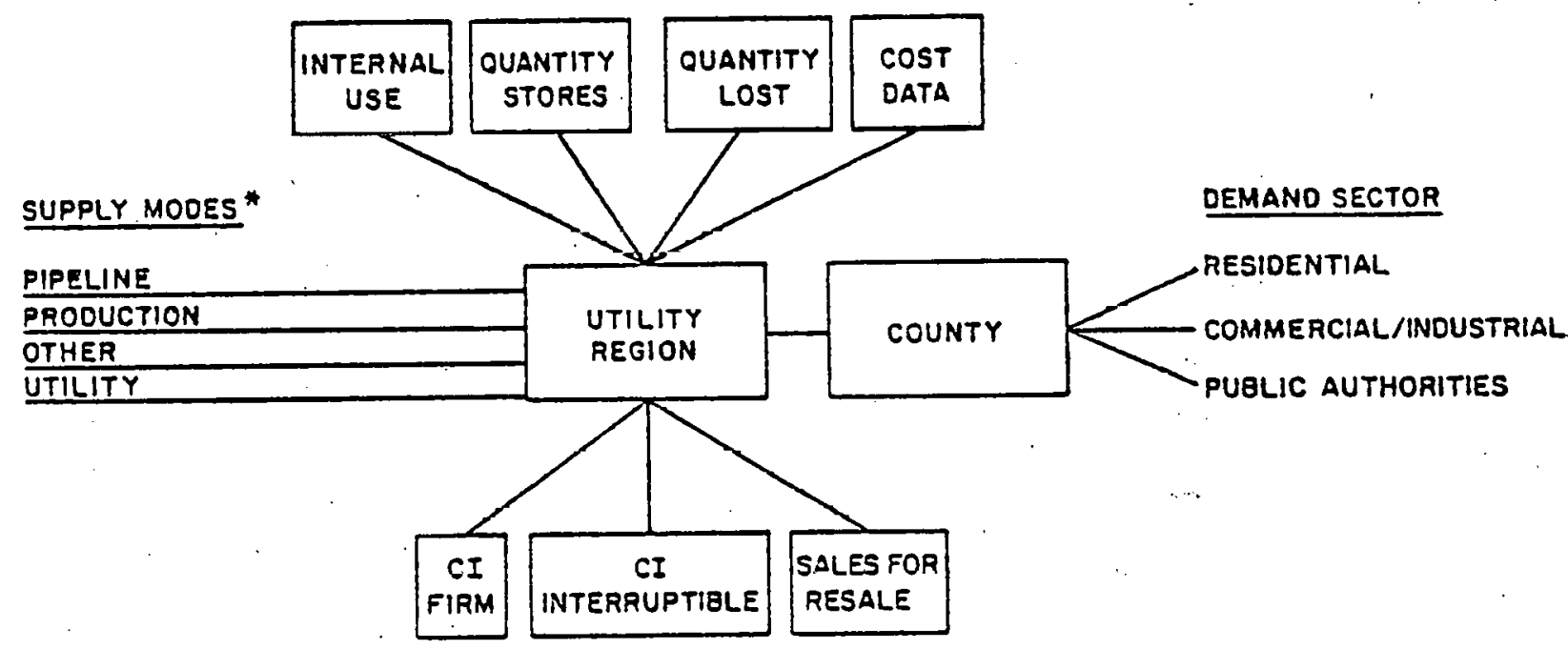

* more tilan one fipelife can suffly a utility recion

Figure 15. STRUCTURE FOR NATURAL GAS. 


\subsubsection{Electricity}

The structure for electricity is presented in Figure 16. Electricity is supplied to a region by an electric utility. Each utility generates electricity by using a combination of any of the following types of power plants:

Nuclear

Coal

Gas

0 i1

Hydro

Eight major electric utilities operate in New York State. Each utility supplies electricity to an electric utility region. These regions may overlap so that a county can be in more than one electric utility region.

Detailed information on fossil fuel fired generating plants is available. These data include:

Fuel Consumption by Power Plant

Pollution by Power Plant

Individual Unit Data

The County in Which the Plant is Located

The demand sectors include:

Residential

Commercial/Industrial

Public Authorities

Demand and supply data are measured in MWhr (Megawatt hours): Cost

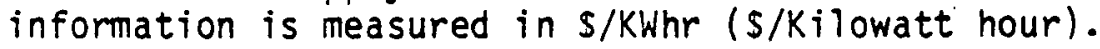

\section{$5.2 .3 \quad$ Coal}

The structure for coal is presented in Figure 17. Coal is transported into a region via one of the modes, including:

Rail

Truck

Water

There are seven coal utility regions in the state, named after one of the seven major electric utilities in the state. Unlike the utility regions for natural gas and electricity, however, coal utility regions do not overlap.

Demand data are provided for each of the following sector.

Electric Utilities - Bituminous and lignite coal supplied to electric utilities for the generation of electricity

Industrial Customers - Bituminous and lignite coal supplied to industrial customers

Coking Coal - Bituminous and lignite coal used in the coking process

Anthracite - Anthracite demand

Other - Miscellaneous demand

Cont demand and supply data are in units of 1000 tons. 


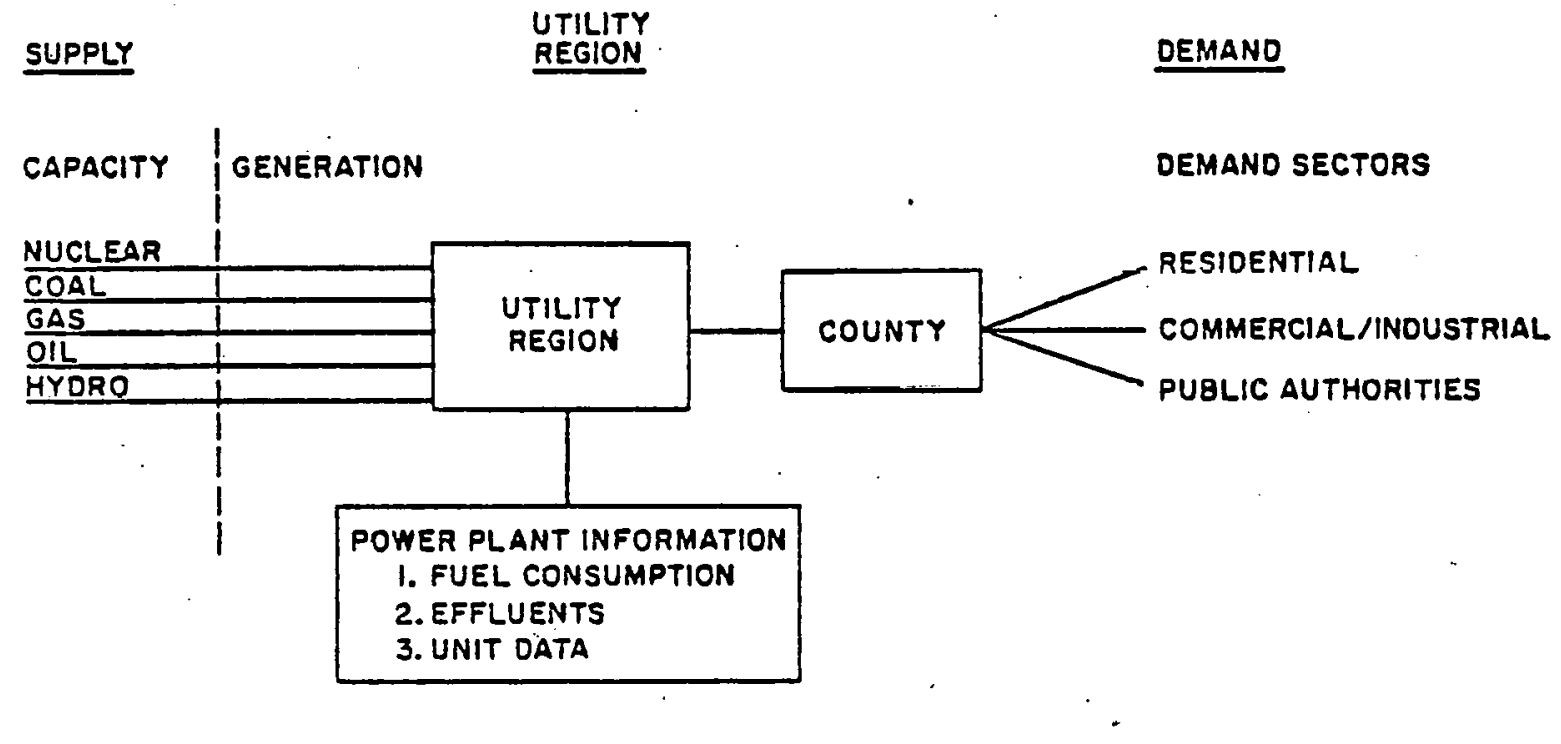

SUPPLY

SUPPLY MODES

RAIL

TRUCK

WATER
Figure 16. STRUCTURE FOR ELECTRICITY.

UTILITY

UTILITY REGION

2. EFFLUENTS 


\subsubsection{Petroleum}

The structure for petroleum is presented in Figure 18. Petroleum is transported into the state by the following modes:

Truck

Water Transportation

Pipeline

The petroleum utility regions coincide with the coal utility regions. Each region receives both a domestic and a foreign supply of oil, and might contain a refinery that receives crude $0 i 1$.

The demand sectors include the following:

Residential Sector

Commercial Sector

Transportation Sector

Demand and supply data are measured in 1000 barrels (mbbl).

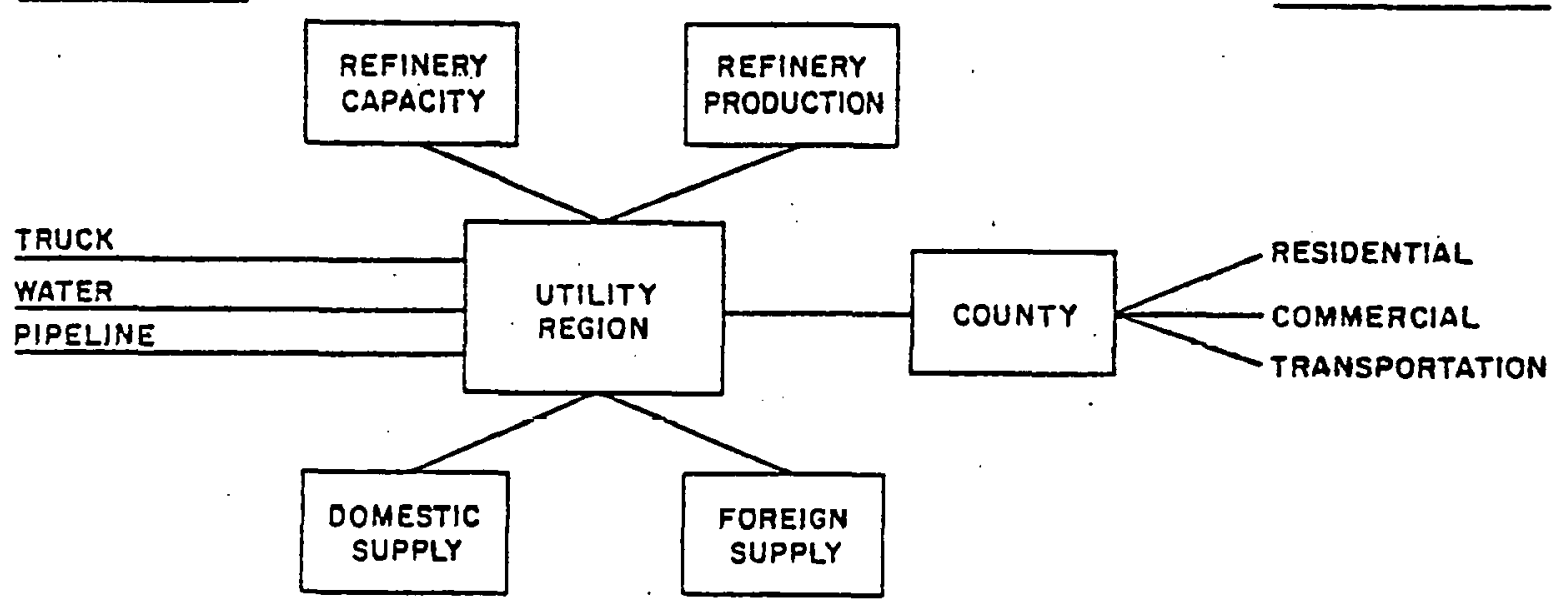

Figure 18. STRUCTURE FOR PETROLEUM. 


\subsubsection{Solid Waste}

Solid waste is not examined in the same structural terms as the other fuels previously discussed. Solid waste is not a fuel source that was consumed in substantial amounts in 1976, but is considered likely to be a significant energy resource in future years. For this reason data of solid waste by regions of the state have been included.

The potential for the generation of solid waste is estimated only for those counties included in Standard Metropolitan Statistical Areas (SMSA's) since it is unlikely that sufficient useful material would be produced in counties with low population densities.

The potential for energy generation from solid waste is measured in Btu $\times 10^{9}$.

\subsection{COUNTY LEVEL SUPPLY AND DEMAND}

In the previous section we examined the structural elements of each of the fuels included in the county level data base.* In this section, we describe the data and data sources for each of the fuels.

\subsubsection{Natural Gas}

The primary sources of information for natural gas were the State of New York Public Service Commission Reports (PSC) 40 filed by each gas utility in the state. These reports included the following information:

1. Total sales to residential; industrial and commercial (combined) and public authority customers.

2. The cost per thousand cublc feet of gas to each of these customer classiffications.

3. Consumption by communities with a population of 10,000 or more (by customer classifications).

4. Supplies to a utility and their cost per Mcf.

5. Gas production by a utility.

6. Utility internal use of gas, storage, sales for resale, and losses in the system.

7. Industrial interruptible and firm requirements.

County data was derived from the above sources for many of the utilities. However, if a utilities PSC report did not contain county data, further information was requested. If the data required remained unavailable, estimates were made of consumption by customer classification for those communities with a population of less than 10,000. (As noted above the PSC reports did contain consumption data for those communities of 10,000 or more). These estimates were based on the population of the communities.

* County level data appear in Appendix B. 
There are 15 major in addition to several small municipal gas utilities in the state. The abbreviation used for the utilities, as well as the supply types and units of measurement, are described in Table 21. The gas pipelines supplying the state are named in Table 22, and the counties serviced by each utility are presented in Table 23.

A detailed description on how to gain access to the gas data and the type of data that is available is presented in Appendix $C$.

\subsubsection{Electricity}

Information on county consumption of electricity was requested from each electric utility in the state. County consumption for Con Ed customers was obtained from their annual yearbook. ${ }^{2}$ Niagara-Mohawk did not provide exact County data, but they were able to provide enough information so that we were able to estimate accurately county consumptions for their region.

Environmental emissions were calculated for each power plant in the state from environmental coefficients found in References 3 and 5 and fuel consumption data from the Federal Power Comission (FPC).4

Installed capacity and generation in 1976, as well as additional information on fuel consumed, were obtained from the New York Power Pool Report. Unit data was al so obtained from References 1 and 5.

Data of total cost and cost/kilowatt hour (kwh) were provided by the utility or calculated from information in Moody's Public Utility Manual, 1977.6 Cost data were not available for any of the PASNY customers.

The environmental coefficients were originally taken from a report by the Committee on Nuclear Alternative Energy Systems, Risk-Impact Panel Study on Routine Emissions from Energy Sources.

Typical bill information for each utility by customer classification was taken from Typical Electric Bills, 1977, prepared by the FPC. ${ }^{7}$

Table 24 1ists the counties served by each electric utility in the state. Note that the abbreviations used are the same as those for the gas utilities.

A more detailed description on access to the electricity data and the type of data available, is presented in Appendix $C$.

\section{$5.3 .3 \mathrm{Coal}$}

The determination of county consumption of coal in N.Y. is difficult. There are numerous supplies of coal to numerous recipients. In the paragraphs which follow we describe available data sources and the way they were utilized in making estimates for this project. 
Table 21

MAJOR GAS UTILITIES IN N.Y. AND SUPPLY TYPES

\begin{tabular}{ll} 
Brooklyn Union GaS Company & \multicolumn{1}{c}{ Abbreviation } \\
Central Hudson Gas \& Electric Corp. & Brookiyn Union \\
Columbia Gas of New York, Inc. & Central Hudson \\
Consolidated Edison Co. of N.Y., Inc. & Columbia \\
Corning Natural Gas Corp. & Con Ed \\
Long Island Lighting Co. & Lilco \\
National Fuel Gas Dist. Corp. & National Fuel \\
New York State Electric \& Gas Corp. & NYSE\&G \\
Niagara Mohawk Power Corp. & Niagara Mohawk \\
Orange and Rockland Utilities & Orange \& RockTand \\
Pavilion Natural Gas Co. & Pavilion \\
Pennsylvania \& Southern Gas Co. & Penn \& South \\
Rochester Gas \& Electric Corp. & RG\&E \\
St. Lawrence Gas Co., Inc. & St. Lawrence \\
Syracuse Surburban Gas Co., Inc. & Syracuse Suburban \\
Supply Types & Type of Gas \\
Pipeline Abb \\
Production & Synthetic \\
Utility & Natural \\
Other & \\
Units of Measurements & \\
S/Mcf & \\
Units in Mcf &
\end{tabular}

Table 22

GAS PIPELINES SERVICES, N.Y.

Name

Columbia Gas Transmission Corp.

Algonquin Gas Transmission Corp.

Tennessee Gas Pipeline Company

Texas Eastern Transmișsion Company

Columbia LNG Corp.

Algonquin Gas Transmission Corp.

Consolidated Gas Supply Corp.

North Penn Gas Co.

Transcontinental Gas Pipe Line Corporation

Trans Canada Pipeline

National Fuel Gas Supply Corp.

Distri Gas Corp.

Ashland 0 il Co.
Abbreviation

Columbia Nat.

Algonquin Nat:

Tennessee

Texas-Eastern

Columbia Syn

Algonauin Syn

Consolidated

North Penn

Transcontinental

Trans Canada

Mational

Distri Gas

Ashland Syn 


\section{COUNTIES SERVICED BY MAJOR GAS UTILITIES, NEW YORK STATE}

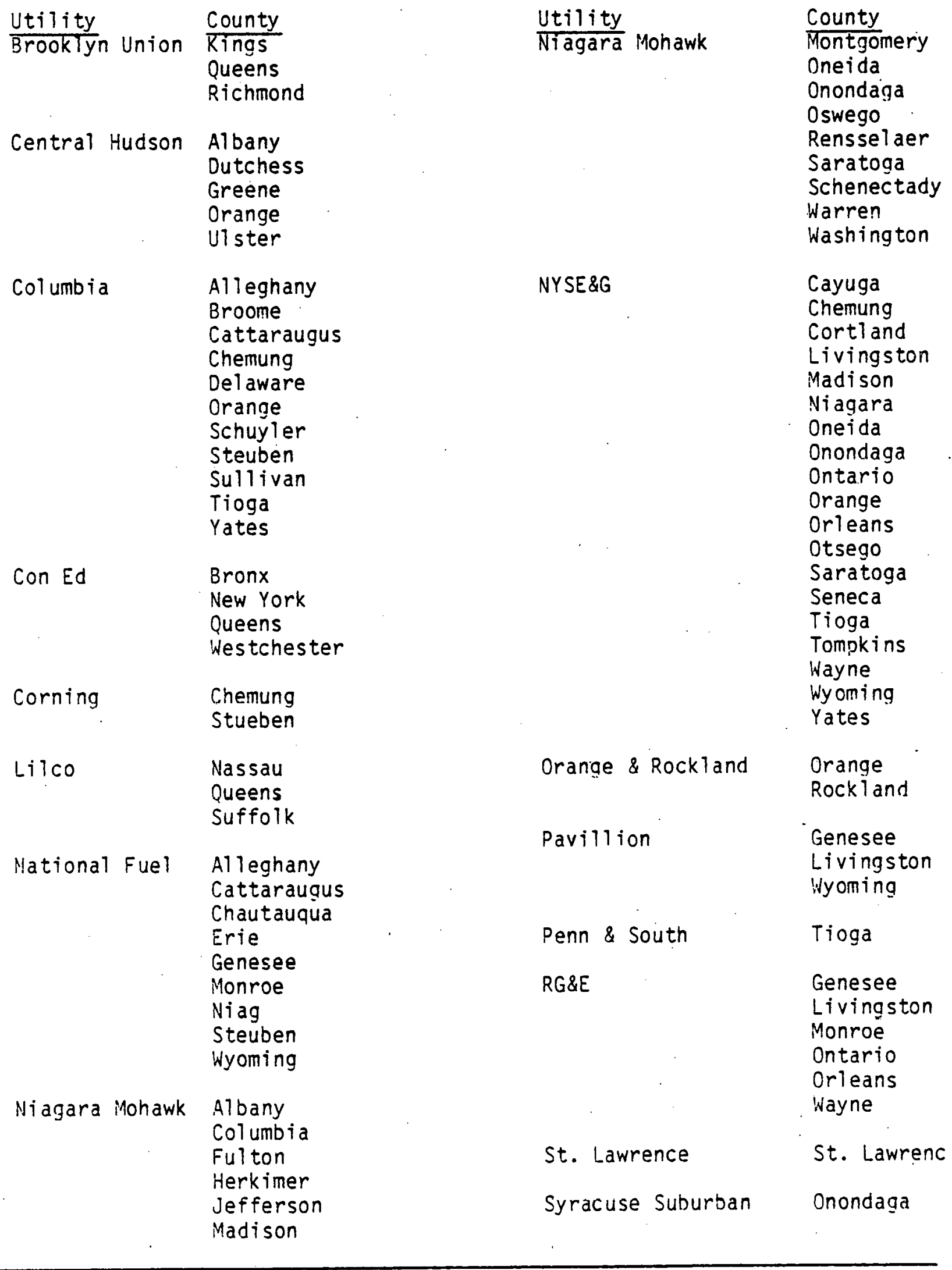


The U.S. Bureau of Mines ${ }^{8}$ provides data of bituminous coal and lignite distribution for the entire state. These data include the transportation method by which the coal is delivered. This reference was key to our estimate of county demand.

In addition Federal Railroad Administration Waybill Statistics for 1972-76 of coal deliveries to N.Y.S. based on a $1 \%$ sample and the N.Y. State Department of Transportation $100 \%$ sample of deliveries in $1973,70 \%$ of the railroads in the state, were al so useful.

Approximately $45 \%$ of the bituminous coal consumed in the state is used by electric utilities. The consumption of coal by power plants was obtained from the FPC. ${ }^{4}$ From this source we were able to determine the counties in which the plants are located. Information on the transportation method by which this coal was delivered to specific plants was obtained either through the New York Power Pool report or through conversations with employees of the electric utilities in the state.

Approximately $38 \%$ of the bituminous coal delivered to N.Y. in 1976 was used in coking plants. Almost all of this coal was delivered by rail, with the remainder delivered by water across the Great Lakes. It appeared from the data available in the waybill Statistics and from the location of coking plants in N.Y., that the Niagara-Erie area was the principal recipient of coking coal. Since the breakdown between Niagara and Erie could not be determined, all of the coking coal was assumed to be delivered to Erie County.

The remaining amounts of bituminous coal delivered to N.Y. Were nrimarily consumed by industrial customers, through some residential and commercial customers, though some residential and commercial customers do require coal. The New York State Energy Office provided us with information on coal consumption by primary industrial consumers of coal. Though the consumption data reported by the industries might not be considered highly accurate, the total coal consumption reported by the industries in 1976 agreed within 3\% with the amount reported in Reference 8 under its "all others" category. The majority $(92 \%)$ of coal used by industrial customers entered the state by rail, though many of these consumers might have received final delivery by truck.

Data of anthracite deliveries to $W . Y$. were obtained from the Department of Energy. 9 These data were on a statewide or regional level. There were no data available to enable disaggregation at a county level.

The coal utility regions and the counties which they include are listed in Table 25. 
COUNTIES SERVED BY ELECTRIC UTILITIES

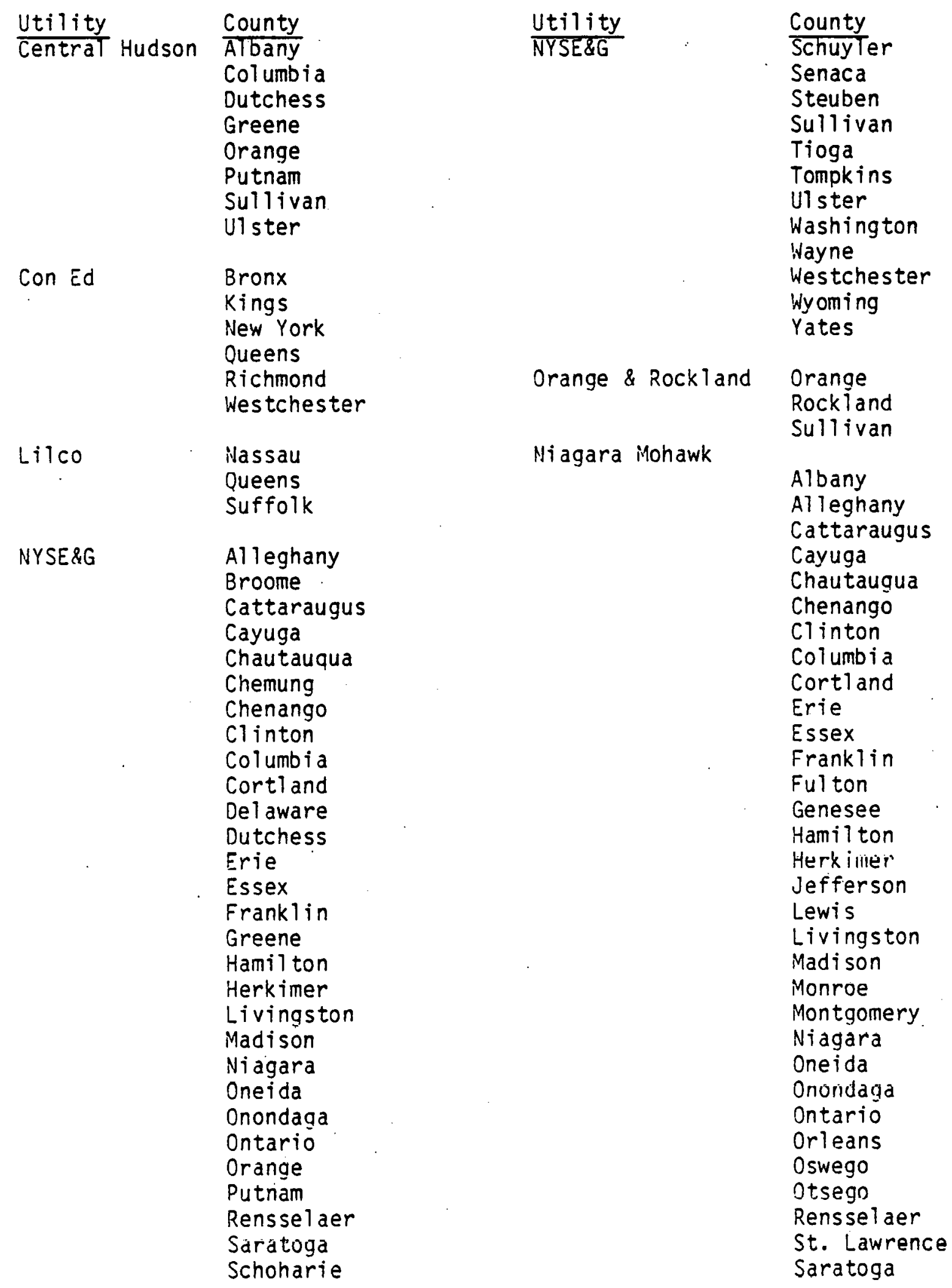


Table 24 (continued)

COUNTIES SERVED BY ELECTRIC UTILITIES

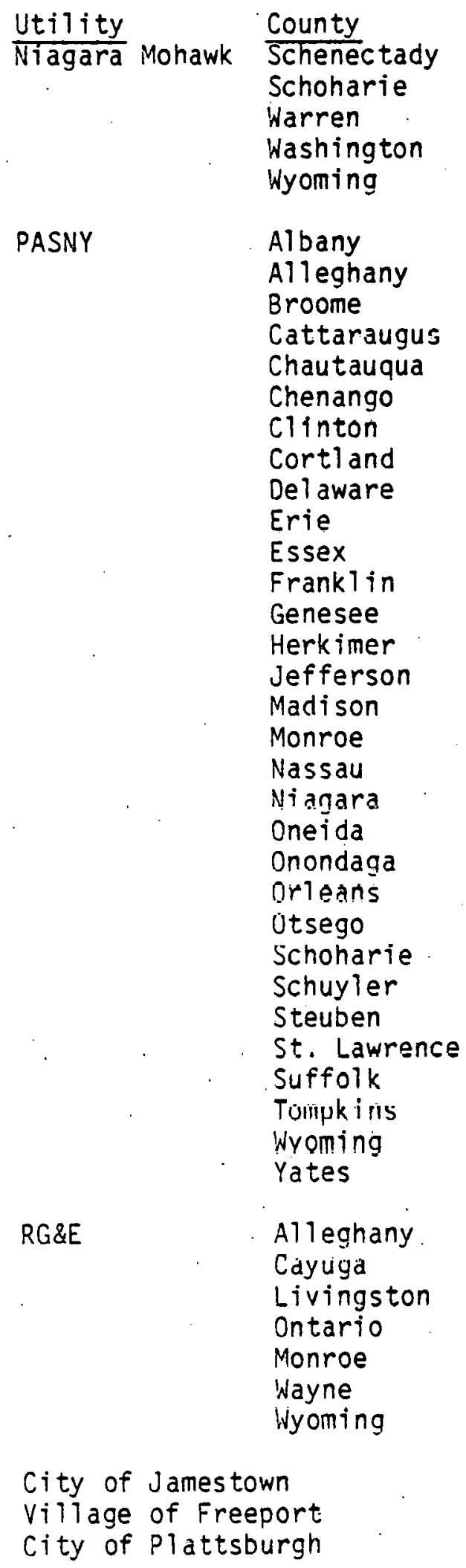




\section{3 .4 Petroleum}

County petroleum demands have been calculated separately for the residential, commercial and transportation sectors.

For each of the three sectors, since county level supply information was lacking, county shares of aggregate state demand were determined on the basis of appropriate allocating measures described below.

Residential Sector: The county information for the resiential sector was provided by the 1970 Detailed Housing Report, which gave the number of housing units in each county broken down according to building types, end-uses and fuels used for the end-uses. These numbers were then projected to 1976, taking into consideration the changing characteristics of new housing. The county changes for the residential sector were determined by first multiplying for each housing type and end-use the numbers of housing units that used oil by the unit demand for a house in that housing type and end-use category, and then adding across all housing types and end-uses.

Commercial Sector: Estimation of commercial oil demand involved two separate steps. First, the total commercial fuel demand was computed for each county, and then a portion of that demand was alloted to $0 i 1$.

The commercial sector consists of five subsectors: retail, services, offices, hospitals and schools. Each county's share of New York State cormercial energy demand depends, thus, on a sum of its shares in the five subsectors weighted by the subsectors' fractions of total commercial energy demand.

For the services, retail and office subsectors the county shares were alloted according to employment figures in these subsectors as given by the New York State Business Fact Book. 10 (The category: "Finance, Insurance, and Real Estate" was taken to represent the office subsector.) The school shares were determined by enrollment as documented in the 1975 Survey of Enrollment, Staff and Schooling. 11 Finally, as there were no compiete source of data on hospitals, the state hospital energy fraction was divided in proportion to the county populations. In this manner five shares were determined for each county with their sum providing commercial energy demand for that county.

An added consideration arose from the fact that in the commercial sector, there is no direct information as to how county energy demand breaks down between $0 i 1$ and the other fuels. The reasonable assumption was made that the commercial fuel is likely to resemble the residential mix in the sense that 
COAL UTILITY REGIONS IN N.Y.

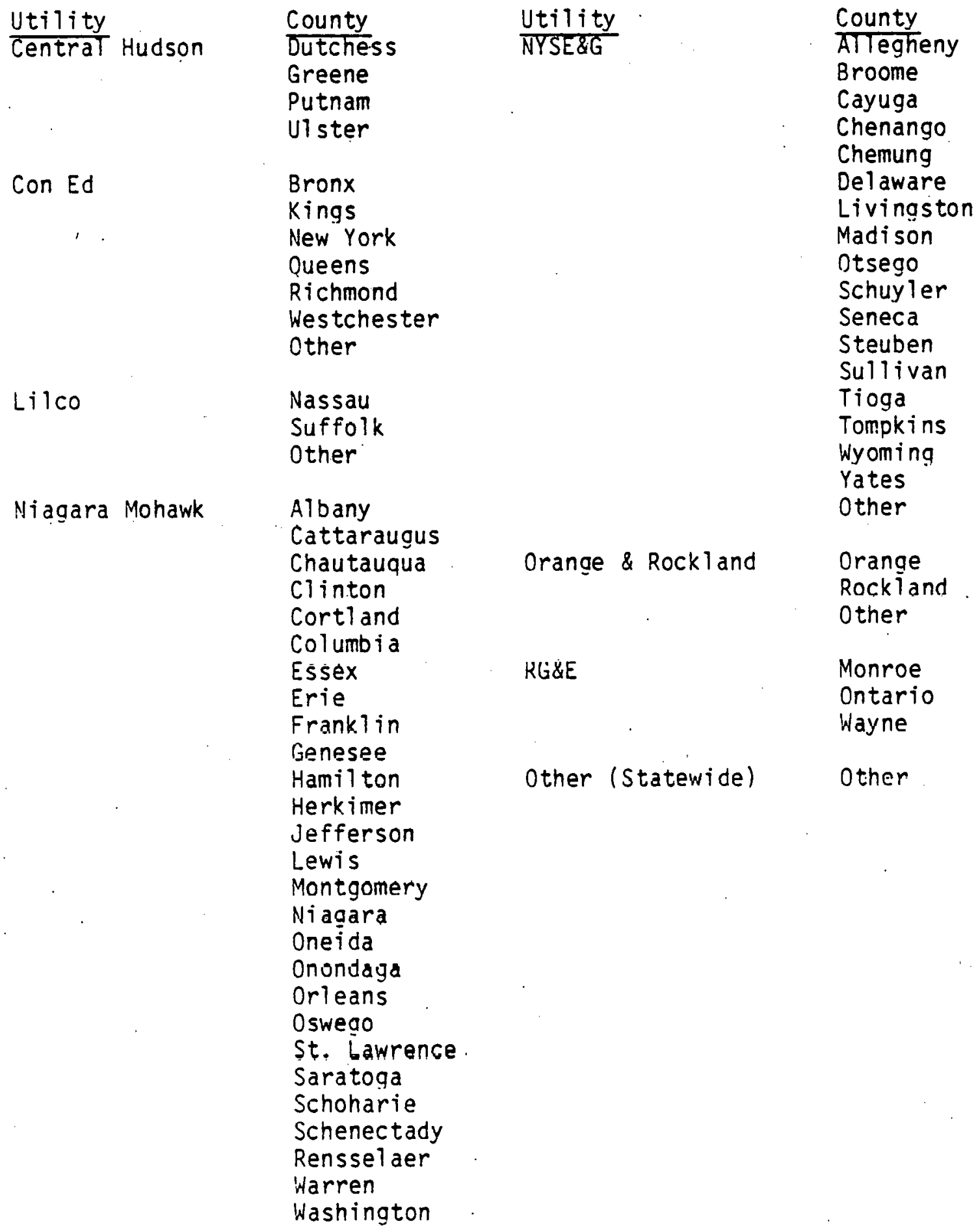

Utility

Central Hudson

Albany

Chautauqu

Clinton

Cortland

Columbia

Essex

Erie

Herkimer

Lewis

Montgomery

Niagara

Oneida

Onondaga

Orleans

Osweao

t. bawrence

ratoga

Washington
Utility

NYSE\&G

Allegheny

Broome

Delaware

Madi son

otsego

Schuyler

Seneca

Steuben

Tioga

Tompkins

Orange

Rockland

other

Monroe

Ontario

wayne

other 
counties with high residential oil use, for example, are al so high in commercial oil use.

Transportation Sector: Data for the disaggregation of transportation oil demand came from two sources:

a) The N.Y.S. Department of Motor Vehicles provided information on the number of motor vehicle registrations. 12

b) A N.Y.S. Department of Transportation report provided estimates of the average annual miles per vehicle for nine SMSA regions in New York State and also for the counties that are not included in any SMSA region. 13

The county shares of the aggregate state transportation oil demand were determined, then, by the product of the number of motor vehicle registrations in a county and the average number of miles per vehicle the SMSA that includes that county. A11 counties not in an actual SMSA were grouped in a fictitious SiMSA for this purpose.

\section{3 .5 Solid Waste}

Solid waste data came from Reference 14 which provided, by SMSA region, the potential yield from refuse combustion in 8 tu/yr for 1970 , and the per capita refuse generation estimates for 1975 and 1980. By allowing for changes in population and the changing per capita yield we estimated the potential yield (again in Btu/yr) for 1976. For each SMSA region, this yield, then, was allocated among the counties in that SMSA according to the relative share of its population they contained. The 31 counties that do not fall within any SinSA region were given a yield of 0.0 since refuse combustion for energy generation does not seem to be practical for nonurban areas. 
1. Public Service Commission Reports Nos. 182 and 207, Filed by New York State Utilities for 1976.

2. Consolidated Edison Co., "Operating Statistic Yearbook, 1976," New York, N.Y.

3. USEPA, "Compilation of Air Pollution Emission Factors, "AP42, Feb., 1976.

4. Federal Power Commission, Bureau of Power, "Annual Summary of Cost and Quantity of Electric Utility Plant Fuels, 1976," Washington, DC, May, 1977.

5. New York Power Pool, "Report to Member Electric System of the New York Power Pool Pursuant to Article VIII, Section 149-b of the Public Service Law, Vol. I."

6. Moody's Investors Service, Inc., Moody's Public Utility Manual, 1977, New York, NY.

7. Federal Power Commission, Typical Bills 1977, Washington DC.

8. U.S. Dept. of Interior, Bureau of Mines, "Bituminous Coal and Lignite Distribution, 1976," Washington, DC.

9. USDOE, Energy Data Reports, 1976 Wash., OC.

10. NYS Dept. of Commerce, "NYS Business Fact Book, 1976 Supplement," Albany, N.Y.

11. NYS Education Dept., "Survey of Enrollment, Staff and School Housing, Fall 1976," Albany, N.Y.

12. NYS Dept. of Motor Vehicles, "Motor Vehicle Registrations, Licenses, Fees Collected, Deductions and Monies Available for Uistribution, 1975," MV215, Apri1, 1976, Albany, NY.

13. D. Gooding, "Automotive Energy Use: A Baseline Projection for NYS," NYS Dept. of Transportation, PPR 124, ATbany, NY, August, 1977.

14. P Meier and T. McCoy, "Solid Waste as an Energy Source for the Northeast," BNL 50559, Brookhaven National Laboratory, Upton, NY, June, 1976. 


\section{CHAPTER VI}

SHORT RUN PRICE AND WEATHER MODELS

\subsection{INTRODUCTION}

In this chapter we examine two short-run models included in the NYS EIAS for the purpose of addressing the need of decision makers to respond to two specific changes in the determinants of energy demand: price and weather.. In the case of the former our interest here is further directed to consumer's short-term response to prices.

In the next section (6.2) we focus on the short-term response model. We examine the elasticities of demand chosen for incorporation in the model and their derivation. There is considerable uncertainty as to precisely how consumers will respond in the short run to energy price changes and so our model permits the inclusion, at the users option, of alternative elasticities.

In section 6.3 we present the Weather Sensitive Energy Demand Model. Demand of the residential and commerical sectors only are addressed.

Use of the computerized version of these models is described in Appendix $C$.

\subsection{SHORT-TERM PRICE RESPONSE MODEL}

The Price Elasticity Model is a Fortran program that converts general assumptions about consumer sensitivity to price variation (price elasticities) and specific assumptions about future price behavior into predictions of future energy demand.

Price elasticity is a concept that describes how sensitive the demand for one commodity is to change in price of that or some other commodity. More precisely, the elasticity of demand of commodity $A$ with respect to the price of commodity $B$ is defined as the ratio of two quantities: the relative change is the demand for $A$ which is induced by the relative change in the price of $B$. of particular significance are price elasticities for the special case when $A$ and $B$ are the same commodity. They are most often negative, thus reflecting the fact that an increase in price usually decreases demand. For example; an elasticities of " -1 " would imply that a 10\% increase in the price of a certain commodity would cause a 10\% decrease in the demand for that commodity. When $A$ and $B$ are substitutes the elasticities are positive as a consequence of the fact that an increase in the price of one will increase the demand for the other. 
The Price Elasticity Model is an application of these concepts to the demand for energy. It contains elasticities for four fuels: coal, gas, electricity, and oil. Included in addition to price elasticities of demand are price elasticities of substitution. These are separate elasticities for the commerical/residential and the industrial sectors. In addition the user is enabled to supply alternative elasticities which he may consider to be more realistic representations of consumer behavior. When provided with current demand levels and current and future prices, the program returns the predicted future demand.

\subsubsection{Industrial Sector}

Price elasticities of demand for the industrial sector 1 have been computed utilizing a model that incorporates equations for three simultaneous decisions. The first is an equation for total energy demand lexcluding feedstocks) of the industrial sector. The second is a set of equations used to derive the cross-sectional energy consumption patterns. The final equation is used to derive demands for each of the four specific energy forms.

The short run elasticities are a function for the presently existing market shares of each fuel and the relative existing market shares of each fuel and the relative fuel prices. They have been derived via simulation by altering individually the prices of each energy form (by $5 \%$ ), and then using the simulated results one year after the change to compute the relevant fuel price elasticities. This was done around a trajectory of prices corresponding to those used by FEA in the Project Independence Report. Short run price elasticities of demand for the industrial sector are given in Table 26.

\subsubsection{Residential and Commercial Sectors}

Price elasticities of demand for the residential and commerical sector have been derived from a model ${ }^{2}$ consisting of two parts. The first determines aggregate demand for energy in all forms, the second estimates market shares for three major fuels (electricity, natural gas and petroleum products). Aggregate energy demand is assumed to be a function of the weighted average energy price, personal income, and the numbers of heating and cooling degree days. The market share for (each individual) fuel is assumed to be a function of its price, prices of substitute fuels, personal income, and degree days.

The short run elasticities were derived via simulation by altering the prices of each energy form and using the simulated results one year after the change to compute the relevant elasticities. These elasticities are given in Table 27. 
Table 26

SHORT RUN ELASTICITIES OF DEMAND: INDUSTRIAL (1)

\begin{tabular}{lrrrr} 
& $P g$ & $P o$ & $P e$ & $P C$ \\
\hline GAS & -.07 & .01 & .03 & .01 \\
OIL & .06 & -.11 & .03 & .01 \\
ELECT. & .06 & .01 & -.11 & .01 \\
COAL & .06 & .01 & .03 & -.10
\end{tabular}

Table 27

SHORT RUN ELASTICITIES OF DEMAND: RESIDENTIAL \& COMMERCIAL (2)

\begin{tabular}{lrrr} 
& $\mathrm{Pg}$ & $\mathrm{PO}$ & $\mathrm{Pe}$ \\
\hline GAS & -.06 & .01 & .04 \\
OIL & .02 & -.08 & .04 \\
ELECT. & .02 & .01 & -.13
\end{tabular}

Table 28

NERA LONG RUN ELASTICITIES OF DEMAND FOR N.Y.S. (3)

\begin{tabular}{|c|c|c|c|}
\hline Industry: & $\mathrm{Pg}$ & Po & $\mathrm{Pe}$ \\
\hline $\begin{array}{l}\text { GAS } \\
\text { ELECT. }\end{array}$ & $\begin{array}{r}-.6 \\
.1(a) \\
.2(b)\end{array}$ & .1 & $\begin{aligned} & .04 \\
&-.4(\mathrm{a}) \\
&-.5(\mathrm{~b})\end{aligned}$ \\
\hline
\end{tabular}

\begin{tabular}{|c|c|c|c|}
\hline \multirow{3}{*}{$\begin{array}{l}\text { Commercial } \\
\text { GAS } \\
\text { ELECT. }\end{array}$} & $\mathrm{Pq}$ & Po & $\mathrm{Pe}$ \\
\hline & -.4 & & \\
\hline & $\begin{array}{r}-8(a) \\
0(b) .\end{array}$ & $\begin{array}{l}.8(a) \\
.4(b)\end{array}$ & $\begin{array}{l}-.8(a) \\
-.4(b)\end{array}$ \\
\hline
\end{tabular}

\begin{tabular}{lrrr} 
Residential: $P g$ & Po & Pe \\
\hline GAS & -.2 & .2 & 0 \\
ELECT. & 0 & .5 & -.5
\end{tabular}

(a) Central and Western New York

(b) Downstate region

White the elasticities of Tables $26-28$ are included in the computerized version of the price response model, the user at his option may supply al ternative elasticties. 
It must be noted that the above short term (1 year) elasticities were computed on the national level. NERA ${ }^{3}$ has derived a set of long run (10-12 years) elasticities for New York State. (See Tabie 28.) It is assumed that elasticities are generally greater in the long run than in the short run due to changes in capital stock. Using the NERA elasticities as a ceiling, the short term national figures are consistent with this assumption.

\subsection{WEATHER SENSITIVE ENERGY DEMAND MODEL}

The New York State Energy Information System Weather Model calculates the change in fuel demand which can be expected in the state due to a variation in temperature. The model is based on projections of the number of households in six regions of the state and the amount of commercial floorspace. It uses a specified number of heating and cooling degree days and energy-intensity factors to arrive at the actual change in end-use fuel demand. The data for the model was collected from the same sources used for the main New York State Energy Information System Data Bases, and is consistent with that information. The computer program has several options which allow sensitivity analyses to be performed on the calculation of change in fuel demand. Saturation levels, fuel efficiencies, housing mix, and floorspace mix may be individually altered to study their effect on expected change in fuel demand as a consequence of temperature variation.

\subsubsection{Residential Sector - Space Heat}

The number of households in each of the six regions. (i) which heat with fuel $(j)$ in subsector $(p)$ and are in county $(k)$ was derived from the formula:

$$
\begin{aligned}
& N_{i j p}^{t}=\sum_{k} H_{k t} f_{k i p}^{70} \times g_{k i j}^{70} \text { where } H=\text { number of houses in county } k \text { in year } t \\
& f \text { - fraction of the total number of } \\
& g=\text { fraction of the total number of } \\
& \text { homes in } 1970 \text { in county } k \text { and region } \\
& i \text { which heat with fuel } j \\
& i=\text { region }(1-6) \\
& j=\text { fuel (oil, gas, electricity, or } \\
& \text { other) } \\
& k=\text { county in region } i \\
& p=\text { subsector (single family, low } \\
& \text { density, low rise, or high rise) } \\
& t=\text { target year }
\end{aligned}
$$


The number of households in each county for each time period $\left(H_{k}^{t}\right)$ was abstracted from the New York State Economic Development Board (NYSEDB) Household Projections for 1978.4 The fraction of the total number of homes in each subsector $\left(f_{k i p}^{70}\right)$ and the fraction of the total number of homes heating with each fuel $\left(g_{k j j}^{70}\right)$ were computed from the 1970 Census of Housing, Detailed Structural Characteristics. 5 "Other" fuel includes wood and kerosene used for space heating.

Projections. The space heat housing mix is projected to 1985 using two county growth rates abstracted from the NYSEDB Household Projections--one for 1975 to 1980, and from 1980 to 1985. This growth rate is applied to each of the twelve $N_{i j k p}^{t}$ in each of the counties, and the result aggregated up to the six regions. Five year growth rates for the twelve $N_{i j p}^{t}$ in each of the regions were then computed and stored in the program's data base, to be used for interpolation to target years between 1975 and 1985 .

Fuel demand. Calculation of the fuel demand change for the target year is done through multiplication by heating degree days, energy-intensity factors, (Table 29) and fuel efficiencies (Table 30). The user inputs the first variable; the last two are stored in the program data base.

Table 29

ENERGY INTENSITY FACTORS; RESIDENTIAL SECTOR - SPACE HEAT6

\begin{tabular}{lcc} 
Subsector & $\begin{array}{c}\text { After } 1970 \\
\left(\text { Btu } /{ }^{\circ} \text { day }\right)\end{array}$ & $\begin{array}{r}\text { Before } 1970 \\
\left(\text { Btu } /{ }^{\circ} \text { day) }\right.\end{array}$ \\
\cline { 2 - 3 } Single Family & 10,300 & 14,000 \\
Low Density & 7,400 & 10,200 \\
Low Rise & 5,500 & 7,500 \\
High Rise & 4,000 & 4,300
\end{tabular}


FUEL EFFICIENCIES RESIDENTIAL SECTOR, SPACE HEAT 7

Fuel

0iा

Gas

Electricity

Other $\frac{\text { Efficiency }}{.69}$

.75

1.00

.35

The energy-intensity factors are also based on age of the housing stock in the subsector. The housing $\operatorname{mix} N_{i j p}^{t}$ is broken into age groups built before 1970 and built after 1970) by subtracting the number of houses in region $i$ and subsector $p$ which heat with fuel $j$ that existed in 1970 . If the result ( $N_{i j p}^{t}$ - $N_{i j p}^{t}$ ' is less than zero, the 1 is removal of households taken from the 1970 stock. This occurred in region number 6 - metropolitan New York - high rise apartments. The resulting formula for computation of fuel demand change is

$$
\text { BTU }_{i j}^{t}=\frac{H D D S}{E F F} i\left\{\sum_{p}\left[E I_{p}^{t} \times\left(N_{i j p}^{t}-N_{i j p}^{70}\right)\right]+\left(\sum_{p} E I_{p}^{t} \times N_{i j p}^{70}\right)\right\}
$$

where HDDS = user input heating degree days in region $i$

$E F F=$ energy efficiency of fuel $j$

$E I=$ energy-intensity of a house in subsector $p$ constructed by year $t$

$N^{t}=$ housing stock in region $i$, subsector $p$ which heats with fuel $j$ and was constructed between year $t$ and 1970

$\mathrm{N}^{70}=$ housing stock in region $i$, subsector $p$ which heats with fue ${ }^{\prime} j$ and was constructed before 1970

\subsubsection{Residential Sector - Air Conditioning}

The number of households in each of the six regions ( $i$ ) which cool with air conditioner type $(j)$ in subsector $(p)$ and are in county $(k)$ was derived from the formula:

$$
\begin{aligned}
M_{i j p}^{t}=\sum_{k} H_{k}^{t} \times f_{k i p}^{70} \times s_{i j k}^{t}, \text { where } s= & \begin{aligned}
\text { saturation of air conditioner } \\
\text { type } j \text { in county } k \text { and regton } i \text { in } \\
\text { year } t .
\end{aligned} \\
j= & \text { air.conditioner type (room or } \\
& \text { central) } i, k, p, t, f, H \text { are the same } \\
& \text { as in the space-heating end-use. }
\end{aligned}
$$


Saturations of air conditioner type for each county were derived from the New York Power Pool 8 (Volume I) report on utility studies and projections (Table 31). Each county was classified in a primary utility's service area, and the resulting saturations were aggregated up to the regional level. (Saturation is defined as the number of units in a subsector divided by the number of dwellings in the subsector. Therefore, a saturation can be greater than one.)

Table 31

AIR CONDITIONER SATURATIONS

\begin{tabular}{|c|c|c|c|c|}
\hline $\begin{array}{l}\text { Utility } \\
\begin{array}{l}\text { Hudson } \\
\text { Central }\end{array}\end{array}$ & $\frac{\text { A/C type }}{\text { Room }}$ & $\begin{array}{r}\frac{1975}{.70} \\
.07\end{array}$ & $\begin{array}{r}1980 \\
.85 \\
.10\end{array}$ & $\begin{array}{r}1985 \\
1.05 \\
.12\end{array}$ \\
\hline Con Ed & $\begin{array}{l}\text { Room } \\
\text { Central }\end{array}$ & $\begin{array}{l}.53 \\
.02\end{array}$ & $\begin{array}{l}.43 \\
.19\end{array}$ & $\begin{array}{l}.32 \\
.46\end{array}$ \\
\hline LILCO & $\begin{array}{l}\text { Room } \\
\text { Central }\end{array}$ & $\begin{array}{r}1.02 \\
.12\end{array}$ & $\begin{array}{r}1.21 \\
.14\end{array}$ & $\begin{array}{r}1.41 \\
.17\end{array}$ \\
\hline Niag-Moh & $\begin{array}{l}\text { Room } \\
\text { Central }\end{array}$ & $\begin{array}{l}.32 \\
.02\end{array}$ & $\begin{array}{l}.30 \\
.03\end{array}$ & $\begin{array}{l}.45 \\
.09\end{array}$ \\
\hline NYSEG & $\begin{array}{l}\text { Room } \\
\text { Central }\end{array}$ & $\begin{array}{l}.27 \\
.01\end{array}$ & $\begin{array}{l}.35 \\
.02\end{array}$ & \\
\hline PG\&G & $\begin{array}{l}\text { Room } \\
\text { Central }\end{array}$ & $\begin{array}{l}.35 \\
.06\end{array}$ & $\begin{array}{l}.45 \\
.08\end{array}$ & \\
\hline $0 \& R$ & $\begin{array}{l}\text { Room } \\
\text { Central }\end{array}$ & $\begin{array}{l}.74 \\
.11\end{array}$ & $\begin{array}{l}.76 \\
.14\end{array}$ & $\begin{array}{r}1.05 \\
.19\end{array}$ \\
\hline
\end{tabular}

Projections. The regional saturations for 1975, 1980, and 1985 were used to find a growth rate for the number of air conditioners in each region. It is assumed that for any given year, houses of all ages will have the same saturation. The growth in saturation level is then applied to the number of houses in each regional subsector.

Fuel demand. Calculation of the change in fuel demand for air conditioning in the target year is done through multiplication by cooling degree days, energy intensity factors (Table 32), and fuel efficiencies (Table 33). The user inputs the first variable; the last two are stored in the program's data. base. The energy-intensity factors are based on age of the housing stock in a 
Table 32

ENERGY INTENSITY FACTORS: AIR CONDITIONING END-USE6

\begin{tabular}{lcc} 
Subsector & $\begin{array}{r}\text { After } 1970 \\
\text { (Btu } /{ }^{\circ} \text { day) }\end{array}$ & $\begin{array}{r}\text { Before } 1970 \\
\text { (Btu } /{ }^{\circ} \text { day) }\end{array}$ \\
\cline { 2 - 2 } Single Family & 15,500 & 22,000 \\
Low Density & 12,500 & 17,700 \\
Low Rise & 8,100 & 11,200 \\
High Rise & 5,500 & 5,700
\end{tabular}

Table 33

FUEL EFFICIENCIES - RESIDENTIAL SECTOR - AIR CONDITIONING

$\begin{array}{cc}\text { Air Conditioner Type } & \frac{\text { Efficiency }}{2.0} \\ \text { Room } & 2.5\end{array}$

subsector. The housing mix $M_{i j p}^{t}$ is broken into age groups (built before 1970 and built after 1970) by subtracting the number of air conditioners installed in houses built before 1970. The resulting formula for computation of fucl demand change is:

$$
\text { BTU }_{i j}^{t}=\frac{\operatorname{CDOS}}{E F F j} \cdot i\left(\sum_{\Gamma} E I_{p}^{t} \times\left(M_{i j p}^{t}-M_{i j p}^{70}\right)+\sum_{\Gamma} E I_{p}^{t} \times M_{i j p}^{70}\right)
$$

where $\operatorname{CDDS}=$ user input cooling degree days in region $j$

$E F F=$ energy efficiency of air conditioner type $j$

$E I$ = energy intensity factor for housing stock age $t$, subsector $p$

$M=$ housing stock of age $t$ in region $i$, subsector $p$ which cools with air conditioner type $\mathrm{j}$

\subsubsection{Commercial Sector - Space Heat}

The amount of floorspace for each of the six regions in the five subsectors was obtained by disaggregating 1976 state wide data to a regional level. The disaggregating formula used was:

$$
F_{i p}=\frac{D_{i p}}{D_{p}} \times F_{1} \text { where } D_{i p}=\begin{aligned}
& \text { disaggregating variable in region } i \text {, } \\
& \text { subsector } p
\end{aligned}
$$


THIS PAGE INTENTIONALLY BLANK 


$$
\begin{aligned}
D_{p}= & \text { disaggregating variable, subsector } p \text { state- } \\
& \text { wide total } \\
F_{i p}= & \text { floorspace in subsector } p \text {, region } i \\
F_{p}= & \text { floorspace in subsector } p \text {, state-wide }
\end{aligned}
$$

The disaggregating variable used for each of the subsector were:

Schools -- Enrollment (from NYS Department of Education) ${ }^{9}$

Retail -- Retail Employment (from NYS Business Facts Book) 10

Office -- Office Employment (from NYS Business Facts Book) 10

Hospitals -- Population (from NYSEDB Population Projections, 1978) 4

Services -- Service Employment (from NYS Business Facts Book) 10

The fraction of floorspace heated by each of the three fuels in the commercial sector (oil, gas, or steam). Was extrapolated from the residential fuel mix on a county level. This information was then aggregated to the regional level and stored in the program's data base.

Projections. Space heat for commercial floorspace was projected on a subsector level for each of the five subsectors using population as the projection variable. The fuel mix was held constant. The projected regional values were then adjusted to be consistent with the state-wide totals.

Fuel demand. Calculation of the change in fuel demand for the target year is done through multiplication by heating degree days, energy-intensity factors (Table 34) and fuel efficiencies (Table 35). The user inputs the first variable; the last two are stored in the program's data base.

Table 34

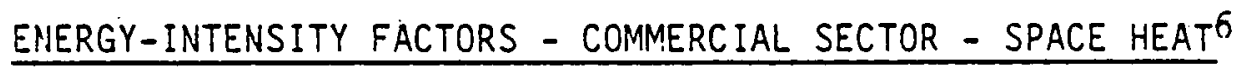

Factor

\begin{tabular}{lc} 
Subsector & (btu/ ${ }^{\circ}$ day/square foot) \\
\cline { 2 - 2 } Schools & 16 \\
Retail & 20 \\
Office & 19 \\
Hospital & 16 \\
Services & 16
\end{tabular}

Table 35

FUEL EFFICIENCIES - COMMEFCIAL SECTOR - SPACE HEAT ${ }^{7}$

\begin{tabular}{lc} 
Fuel & Efficiency \\
\hline Oit & .52 \\
Gas & .53 \\
Steam & .65
\end{tabular} 
The resulting formula for computation of fuel demand change is

$$
B T t_{i j}^{t}=\frac{H D O S_{i}^{t}}{E F F_{j}} \sum_{p}\left(E I_{p} \times F_{i p}\right)
$$

where $B T U=$ fuel demand change in region $i$ for fuel $j$

HDOS = change in heating degree days for region $i$ in year $t$

$E F F=$ fuel efficiency of fuel $j$

$E I=$ energy-intensity factor for subsector $p$

$F=$ space heat floorspace for subsector $p$ in region $i$

\subsubsection{Commercial Sector - Air Conditioning}

The amount of air conditioned floorspace for each of the six regions in the five subsectors was obtained by applying the saturation levels of Table 36 to the floorspace $\left(F_{i p}\right)$ derived in the commercial space heat floorspace calculation.

Table 36

AIR CONDITIONING SATURATIONS - COMMERCIAL SECTOR

Subsector

Schoots

Retail

Services

office

Hospital
Saturation

.20

1.0

.20

1.0

1.0

The formula used for finding the air-conditioning commercial floorspace in each region is:

$G_{i p}=S_{p} \times F_{i p}$ where $S=$ saturation of air conditioner in subsector $p$

$F=$ space heat floorspace in subsector $p$, region $i$

$G=$ air conditioned floorspace in subsector $P$, region $i$

The fuel mix for air conditioned floorspace was estimated to be natural gas $3.6 \%$ and electricity - $96.4 \%$ in each region. These values are stored in the program's data base.

orojection. Air conditioning saturations were assumed to remain constant in each region through the study period. The growth in air conditioned floorspace is thus due only to growth in the space heat floorspace as described above. 
Fuel demand. Calculation of the change in fuel demand for the target year involves multiplying cooling degree days, energy-intensity factors (Table 37) and fuel efficiencies (Table 38) with the amount of commercial floorspace that is air conditioned. The user inputs the first value; the last two are stored in the program's data base.

\section{Table 37}

ENERGY - INTENSITY FACTORS - COMMERCIAL SECTOR - AIR CONDITIONING6

Factor

$\frac{\text { Subsector }}{\text { Schouls }}$

Retail

Office

Hospital

Services

\begin{tabular}{c} 
Factor \\
(btu ${ }^{\circ}$ day $/$ square foot) \\
\hline 15 \\
21 \\
18 \\
15 \\
15
\end{tabular}

Table 38

FUEL EFFICIENCIES - COMMERCIAL SECTOR - AIR CONDITIONING ${ }^{7}$

$\begin{array}{lc}\text { Fuel } & \text { Efficiency } \\ \text { Electricity } & 3.0 \\ \text { Gas } & 1.8\end{array}$

The formula used for the calculation of the fuel demand change is

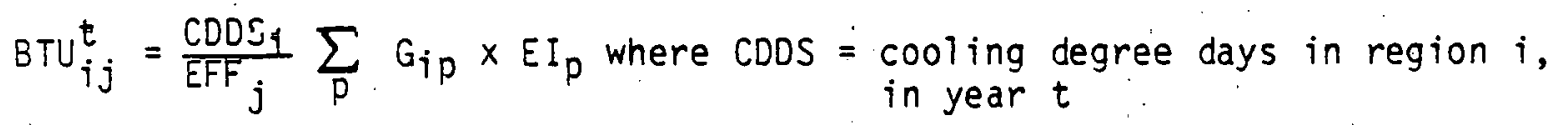

$$
\begin{aligned}
& G=\text { air conditioned floorspace in } \\
& \text { region } i \text {, subsector } p
\end{aligned}
$$




\subsubsection{Region Definition}

The sixty two New York State counties were grouped into six regions, in Table 39, based on three factors--primary utility serving the county, twenty nine heating and cooling degree day normals, and geographical proximity. The first was of concern due to the use of utility based data, and usually coincided with the third. The least variance in the degree day normals was chosen within this constraint.

Table 39

COUNTIES IN NYS REGIONS

The Counties in Region 1

Clinton

Essex

Franklin

Hamil ton

Herkimer

Lewis

Oneida

St. Lawrence

Warren

The Counties in Region 2

Albany

Col umbia

Dutchess

Fulton

Greene

Montgomery

Orange

Putnam

Rensselaer

Rockl and

Saratoga

Schenectady

Ul ster

Washington

The Counties in Region 3

Broome

Chenango

Cortland

Del aware

Madison

Otsego

Schohari

Sullivan

Tioga
The Counties in Region 4

Chautauqua

Erie

Genesee

Jefferson

Monroe

Niagara

Orleans

Oswego

Wayne

The Counties in Region 5

Alleghany

Cattaraugus

Cayuga

Chemung

Livingston

Onondaga

Ontario

Schuyler

Seneca

Steuben

Tompkins

Wyoming

Yates

The Counties in Region 6

Bronx

Kings

Nassau

New York

Queens

Richmond

Suffolk

Westchester 


\section{REFERENCES TO CHAPTER VI}

1. M. Baughman and P. Joskow, "Interfuel Substitution of Energy in the US, Part II: Industrial Sector," April 1975.

2. M. Baughman and P. Joskow, "Interfuel Substitution of Energy in the US, Part I: Residential and Commercial Sectors: May 25, 1974.

3. National Ecomonic Research Associates, "A Long Range Planning Study for New York State Gas Utilities," November 1976.

4. New York State Economic Development Board, "1978 Official Household Projections for New York Counties," January 1978, Albany.

5. U.S. Dept. of Commerce, Bureau of the Census, "Detailed Housing Characteristics, 1970: New York State," Washington, DC, 1972.

6. T. O. Carroli, "A Planner's Energy Workbook," BNL 50633, Brookhaven National Laboratory, Upton, NY, 1978.

7. See Chapter 4 for efficiency references.

8. New York Power Pool, "Report to Member Electric Systems of the NYPP Pursuant to Article VIII, Section 149-50 of the Public Service Law, Vol. 1.

9. NYS Dept. of Education, "Survey of Enrollment, Staff, and Schooling, 1975," Albany, NY.

10. NYS Dept. of Commerce, "Business Fact Book, 1976," Albany, NY. 


\section{FURTHER DEVELOPMENTS}

\subsection{INTROOUCTION}

In the foregoing chapters we described the NYS EIAS at its first stage of implementation. The criteria on which its design was based were examined in the first chapter. In the second chapter we reviewed the BNL Reference Energy System framework and its computerized version, ESNS. In this chapter we suggest future developments in the NYS EIAS. These developments may be conveniently considered in three groups: 1. data base expansion; 2 . extension of the analytic capabilities of the model and, 3. improvement of data quality. Aside from the installation of a facility siting model discussed below we would not recommend the extensions of the model's analytic capabilities in the foreseeable future, preferring to rely on the NYS EIAS's ability to inform policy makers with the latter undertaking analysis as appropriate. This we feel would be more cost effective than "building in" additional analytic capability which might see oniy infrequent use.

\subsection{DATA BASE EXPANSION}

Cost Data. The utility of the NYS EIAS for informing economic analysis would be significantly enhanced by the inclusion of cost data specific to New York in the state aggregate data base. The BNL data base already includes such data on a national basis. However, use of national average cost figures in policy analysis for the State is likely to lead to misleading results. This work would constitute a necessary first step in developing a linked energy-economic analytical capability for the state.

Bibliographical Data. A data set entirely absent in the first stage implementation of NYS EIAS is bibliographical information. Depending on the relative cost and availability of alternative means of accessing such information, it would appear that a selected bibliographical listing of references such as topical and statistical reports, state and federal codes and periodical literature in the area of energy would be a useful addition to the data base.

Industrial Process and Employment Data. Expansion of the data base to include process data of NYS manufacturing activities would permit the elimination of much uncertainty which presently exists in the projection of the energy requirements of this important sector. As we stated in Chapter IV, projections of energy requirements for manufacturing assumed that the fuel mix 
per dollar value added at the level of the two digit SIC was the same in NYS as for the nation as a whole. This assumption seems excessively crude in the face of widely varying processes and equipment vintage in many energy intensive industries.

Further expansion of the data base to include employment in the manufacturing sector as related to output would enable the planner to estimate the employment effects of energy supply curtailment. Employment in the energy activities in ESNS should al so be added so that the employment implications of al ternative energy strategies can be analyzed.

Industrial Location Data. Another data set which would enhance the usefulness of the NYS EIAS at the county level would be locational data of manufacturing activities. Aside from providing planners with a basis for estimating local effects of energy polciy on employment it would al so provide important information to a mapping of point sources of environmental pollution. Such a mapping might be important to the formulation of siting policy for energy conversion facilities. Environmental considerations aside, the location of energy consuming activities is necessary information for planning the siting of dispersed energy conversion facilities serving a small to medium number of large consumers viz., a coal gasification plant serving a cluster of manufacturing establishments.

\subsection{EXTENSIONS OF NYS EIAS ANALYTIC CAPABILITIES: ENERGY FACILITY SITING}

It is likely that the siting of electric generating facilities will remain a substantial policy issue for WYS over the remainder of this century. A substantial enhancement of the Energy Office's policy analysis capabilities in this regard would result from the availability to it of an electric power plant siting model: Presently available at BNL is a linear programing siting model that translates the electric sector generation mix specified by a regional or state energy system scenario to the facilities required at the county level.* The model can be characterized as a multi-commodity transhipment problem, encompassing fuel mining and transportation costs (for each of the many types. of fuel, each of differing heat value and sulfur. content), electric transmission and cost penalties for various environmental control technologies.

*See e.g., "The Brookhaven Regional Energy Facility Siting Model (REFS): Model Development and Application," BNL 51006, Brookhaven. National Laboratory, Upton, New York, June 1977. 
The model is based on the fact that given a particular specification of the generation mix, the siting problem can be reduced to the determination of that set of facility locations that minimizes the sum of coal extraction, coal transportation, and electric transmission costs, subject to meeting certain energy and resource mass balance conditions. Since the generation mix for any particular run is given as part of the scenario, the baseline costs of the generating facilities themselves do not enter into the computation, and only those that are location specific are considered (e.g., due to cooling, or air quality constraints).

The application of the model to New York State would not replace the process of detailed site evaluation as carried out by PASNY or individual utilities, but would provide the state with means to examine broad siting issues. 


\section{ACKNOWLEDGEMENTS}

This report was prepared by the authors for the use of the New York State Energy office. Although we exercised a completely independent judgment in performing the analysis and drawing conclusions we were greatly helped. throughout the study by the lively interest and active collaboration of many of the NYSEO staff. We are particularly indebted to Chip Searle for his advice and counsel throughout the study. We are al so grateful to Dr. David Hartgen of the New York State Department of Transportation for his advice and assistance to us in matters involving the transportation sector.

We have al so profited from the advice and assistance of a number of the staff of the National Center for Analysis of Energy Systems at Brookhaven, including Philip Palmedo, Richard Goettle, Alan Hemelee and Robert Stern.

In addition, we would like to express our appreciation to Patricia Miller and Mary Bruck for typing this manuscript in good cheer while suffering through repeated revisions. 
APPENDIX A

STATE AGGREGATE ENERGY DEMANDS

AND POLLUTANT EMISSIONS 
1

$$
\stackrel{3}{3}
$$

TABLE

APPENDIX A

. FUEL DEMAND TABL.ES-.1976
lEOS BTU

$\therefore$ FUEL DEMAND TABL.ES-.1976
IED BTU

1

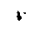

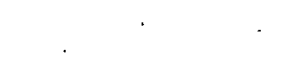

.

. 
NEW YOPK STATE ENEFTY INFORMATION SYSIEM DATCEBASE FEEFERENCES

PAGE

YEAR- 1976 SCCNARIO- BASE CASE 4/01/79

$$
\text { AGRICUI. TURE }
$$

SECTOR-

SUBSECTOR- CROPS

BASIS REFERENIE- CORNELL UNIV., IAJR ENGIN BULL 405,1JULY,1976, AND FARM BUREAU ,HYS DEPI OF AG V6 MKTS UNIT DEMAND REFERE.NCE-SAME AS BASIS

EFFICIENCY REFERI:NCE - ASSUMED

SATURATION REFETRENCE- ASSUMED

TECH FRAC REFERENCE- SAME AS BASIS RE=ERENCE

\section{SUBSECTOR- GLNERAL}

BASIS REFERENCE- CDRNELL UNIV. IAJR ENGIN BULL 4051, JULY.1975, AND FARM BUREAU, PIYS DEPT OF AG $\checkmark$ MKTS UNII DEMAND REFERENCE-SAME AS BASIS

EFFICIENCY RETERENCE- ASSUMED

SATURATION RETFRENCF- ASSUMED

TECIH FRAC IREFERENCE- SAME AS BASIS REFEFENCE

\section{SUBSECTOR- LIVESTOCK}

BASIS REFERENCE- CDRNELL UNIV. . IABRR ENGIN BULL 4051, JULY, 1976, AND FARM BUREAU, MYS DEPT OF AG $\checkmark$ MKTS UNIT OEMAND REFERENCE-SAME AS BASIS

EFF ICIENCY REFERENCE- AJSUMED

SATURATION REFERENCE - AJSUMED

TECH FRAC REFERENCE- SAME AS BASIS REFEPENCE 
SECTOR-

COMMIRCIAL

SUBSECIOR. HISPIIALS

BASIS RIEFERINNIE- BNI. , IASSESSMENT OF NYS ENERGY RDVD PRIORITIESI (BNL 50735, VZ)

UNIT DEMAND RIFERCNCE-GINL, 'FUTURE RESIDENTIAL AND COMMERCIAL ENERGY DEMAND IN THE NORTHEASTI(BNL505SE)

EFFICIENCY RLTLTRENCE- BNL. IFUIURE RESIDENIIAL. AND COMMERC IAL ENERGY DEMAND IN THE NORTHEAST 1.(BNL50552

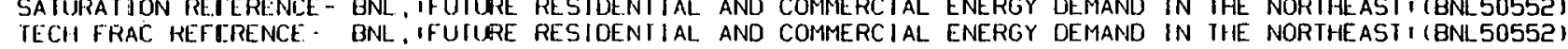

SUBSECTOR- ORFICE BASIS REFERENEE.

AD LITTLE, IPROJ INDEP TASK FORCE REPI I(1974) AND BNL, IASSESSMENT OF NYS ENERGY RDVD PRIORITIES (BNL * UNI I DEMAND RIFERENCE-BNL, 'FUTLRE RESIDENT I AL AND COMMERC I AL ENERGY DEMAND IN THE NORTHEAST I (BNL50552) EFFICIENCY RETERENCE - BNL. IFUILRE RESIDENI IAL AND COMMERC IAL ENERGY DEMAND IN THE NORTHEASTI(BNL50552)

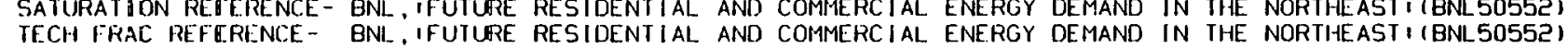

SUBSECIOR- RETAIL

BASIS RE:TERENCE-

AD LITTLE, IPROJ INDEP TASK FORCE REPT I (1974) AND BNL. IASSESSMENT OF NYS ENERGY RDVD PRIORITIESI (BNL * UNI I DEMANU RTFERENCE - BNI, IFUTURE RESIDENT I AL AND COMMERC IAL ENERGY DEMAND IN THE NORTHEAST I (BNL50552) IFI ICICHCY RETERENCE - BNI., IFUTURE RESIDENIIAL AND COMMERCIAL ENERGY DETAND IN THE NORTHEAST I(BNL50552) SATURATUON RERERENCE - BNL. . FUIURE RESIDENTIA. AND COMERCIAL ENERGY DEMAND IN THE NORTHEASIIIBNLSOSSZ TECII FRAC REFTRENCE- BNL, IFUTUURE RESIDENTIAL AND COMMERCIAL ENERGY DEMAND IN THE NORTHEASTI(BNI-5055E)

SUBSECTOR- SCHOOL BASIS REFERENCE-

PHONE CONERSATION WITH MR. LUCE, NYS DEPT OF ED, JUNE, 1978 + STAFF MEMBERS

UNI I DEMAND REFERENCE-GNL. IFUTURE RESIDENTI IAL AND COMMERCIAL ENERGY DEMAND IN THE NORTHEAST I IBNL50552 EFFICIENCY REFERENCE- BNL, IFUTURE RESIDENT IAL AND COMMERCIAL ENERGY DEMAND IN THE NORTHEASTIIBNL50552I SATURATION REFERENCE- BNL, IFUTIRE RESIDENTIAL AND COMMERCIAL ENERGY DEMAND IN THE NORTHEASTIIBNII50552 TECH FRAC REFERENCE- BNL, IFUTURE RESIDENTIAL AND COMMERCIAL ENERGY DEMAND IN THE NORTHEASTI(BNL5OSSD)

SUASSECIOR- SERVICESS BASIS REFERENIE

AD LITTLE, IPROJ INGEP TASK FORCE REPT I(1974) AND BNL, IASSESSMENT OF NYS ENERGY ROVD PRIORITIESI IBNL." UNII DEMAND REFERENCE-BNL, IFUTURE RESIDENT IAL AND COMMERCIAL ENERGY DEMAND IN THE NORTHEAST I(BNL50552) EFFICIENCY REFERENCE - BNL, IFUTURE RESIDENTIAL AND COMMERCIAL ENERGY DEMAND IN THE NORTHEASTIIBNL50552 SATURATION REFERENCE- BNL, IFUTURE RESIDENTIAL AND COMMERCIAL ENERGY DEMAND IN THE NORTHEAST I (BNL50552)
TECH FRAC REFERENCE- BNL, IFUTLRE RESIOENTI IAL AND COMMERCIAL ENERGY DEMAND IN THE NORTHEAST I(BNL50552) 
NEW YDIKK STATE ENLRGY INFORMATICIN SYSTEM DATABASE REFEPENCES

SECIOR-

GUVERNENI

SUBSECIOR- OFFICES

BASI'S REFEFLNCE-

UN1T DEMWWO REFERENCE-SAME AS OFF ICE SUBSECIOF:

SATURATION TERERCL- SAME AS OFF ILE SUBSECTOR

SATURATION REFERENCE-- SAME AS OFF IEE SUBSEC TOP
IECH FRAL REFERENCE- SAME AS OFFICE SUBSECTOP:

SUBSECTOR- PASS TRANG

BASIO RETERENCE-

PHONF. CONVERSAIION WITH MR WHELAN, NYS OFFICE OF GENERAL SERVIEES

UHI I DEMANU REFERENCE-SAME AS AUTO SLIESECTOR

EFFICIENCY REFEREACE- SAME AS AUTO SUESECTOR

SATURATITN TREERENCE- SAME. AS AUTO SUESECTOR

TCCH FRAL REFERENEE - SAME AS AUTO SLIESECTOR 
NEW YORK STAIE ENERCY INHORRMAIION SYSTEM DATABASE REFERENCES

MANUT AC TURING

SUASECIOR- SIC 20

BASIS RREFTFENCE- USDOC, 1976 ANNUAL SURVEY OF MANUFACTURERS AND USDOC, ICURRENT SURVEY OF BUSINESSI(I976) UNIT DEMANO REFERENCE -USDOC, $119 \% 6$ ANNIJAL SURVEY OF MANUFACTURES-FUELS AND ELEC ENERGY CONSUMEDI

EFF ICIENCY REFERENCE- BNAL INIERNAL DATA

SAIUIRATION REFERENCE- BNL INTERNAL DATA
TECH FRAC REFERENCE- SAME AS UNIT DEMAND REFERENCE

SUBSECIOR- SIC - 22

BASIS RFFERENCE- USDOC, 1976 ANNUAL SURVEY OF MANUFACIURERS AND USDOC, ICURRENT SURVEY OF BUSINESS III976) INI I UI:MAND REFERENCE-USDOC, 11976 ANNUAL SURVEY OF MANUF ACTURES-FUELS AND ELEC ENERGY CONSUMED

EFF ICIENCY REFERENCE- BNL INTERNAL. DATA

- SATURATION REFERENCE- BNL INTERNAL DATA
TECII FRAC REFERENCE- SAME AS UNIT DEMAND REFERENCE

SUASECIOR- SIC 23

BASI:5 REFERENCE - USDOC, 1976 ANNUAL SURVEY OF MANUFACTURERS AND USDOC, ICURRENT SURVEY OF BUSINESS II1976I LINI I DEMAND REFERENCE-USDOC, 11976 ANNUAL SURVEY OF MANUFACIURES-FUELS AND ELEC ENERGY CONSUMEDI

EFF ICIENCY REFERENCE- BNL INTERNAL. DATA

SATURATION REFERENCE- BNL INIERNAL DATA

TECH FRAC FEFERENCE - SAME AS UNII DEMAND REFERENCE

SUBSECIOIR- SIC 24

BASIS REFERENCE- USDOC, 1976 ANNUAL SURVEY OF MANUFACTURERS AND USDOC, ICURRENT SURVEY OF BUSINESS III976। UNII DEMAND REFERENCE-USDOC, 1976 ANNUAL SURVEY OF MANUF ACTURES-FUELS AND ELEC ENERGY CONSUMEOI

EFF ICIENCY REFERENCE - BNL INTERNAL DATA

SATUIRATION REFERENCE - BNI INIERNAL DATA

IECH FRAC REFERENCE- SAME AS UNIT DEMAND REFERENCE

SUBSECTOR- SIC 25

BASI'S REFERENCE- USDOC 1976 ANNUAL SURVEY OF MANUFACTURERS AND USDOC ICURRENT SURVEY OF BUSINESSIIIS76I UNII DEMAND REFERENCE-USDOC, 1976 ANNUAL SURVEY OF MANUF ACTURES-FUELS AND ELEC ENERGY CONSUMEDI

EFFICIENCY REFERENCE- BNL INTERNAI. DATA

SATURATION REFERENCE - BNL INTERNAL DATA

TECH FRAC REFERENCE- SAME AS UNIT DEMAND REFERENCE

\section{SUBSECTOR- SIC 2.6}

BASIS REFERENCE.UNII DEMAND REFERENCE-USDOC, 1976 ANNUAL SURVEY OF MANUFACTURES-FUELS AND ELEC ENEFGY CONSUMEOI

EFFICIENCY REFERENCE - BNL INTERNAL DATA

SATURATION REFERENCE - BNL INTERNAL DATA

TECH FRAC REFERENCE- SAME AS UNIT DEMAND REFERENCE

\section{SUESECTOR- SIC 27}

BASIS REFERENCE- USDOC, 1976 ANNUAL SURVEY OF MANUFACTURERS AND USDOC ICURRENT SURVEY OF
INII DEMAND REFERENCE-USDOC, 1976 ANNUAL SURVE OF MANUFACTIJRES-FUELS AND ELEC ENERGY CONSUMED

EFFILIENCY REFERENCE - BNL. INIERNAL. DATA

SATURATION REFERENCE - BNL INTERNAL DATA 
NE.W YORK SIATL. ENE:RCY INFOIMMIION SYSIEM DATABASE REFERENCES

IECH FRAC REFERENCL- SAIIE AS UNIT DE MANIO REFERENCE

SUBSECIOR- SIC 28

BASIS REF ERENCE- USUOC. 1976 ANNUAL SURVEY OF MANUFACTURERS AND USDOC, ICURRENT SURVEY OF BUSINESSI 1976 I

EFF

EFF ICIENCY REFERENCE - BNL. INTERNAL DATA

TECH FRAC REFERENCF. - SAME AS IJNIT DEMANG REFERENACE

SUASECTOR- SIC 30

BASIS REFERENCE- USDOC, 1976 ANNUAL SURVEY OF MANUFACTURERS AND USDOC, ICURRENT SURVEY OF BUSINESSIII976! UNI I DEMANO REFERENCE -USDOC, 11976 ANNRJAL SURVEY OF MANUFACTURES-FUELS AND ELEC ENERG CONSUMED I

EFF ILIENCY REFERENCE - BNL INTERNAL. DATA

SATURATION REFERENCE - BNL INIERNAL DAIA
TECH FRAC REFITRENCE- SAME. A'S UNI'T DEMANO REFERENCE

SUBSECTOR- SIC 31

BASIS REFERENCE- USDOC. 1976 ANNWAL SURVEY OF MANUFACTURERS AND USDOC. ICURRENT SURVEY OF BUSINESSI(1976) UNI I DEMANI) RLFERLNCE.-USDOC, 1976 ANMUAL SURVEY OF MANUFACTURES-FUELS AND ELEC ENERG CONSUMED

EFFICIENCY REFERENCE- BNL INTERNAL DATA

SATUIRATION REFERENCE - GNL INTERNAL DAIA

IECH FRAC REFERENCE - SAME AS UNIT DEMAND REFERENCE

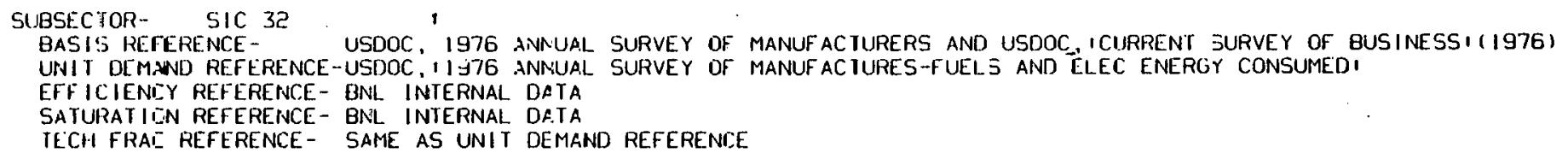

SUBSECTOR- SIC 33

BASIS REFERENCE- USOOC, 1976 ANMUAL SURVEY OF MANUFACTURERS AND USDOC, ICIJRRENT SURVEY OF BUSINESSI(I976) UNI I DEMEND REFERENCE-USDOC, 11976 ANMUAL SURVEY OF MANUFACTURES -FUELS AND EI-EC ENERGY CONSUMEO

EFF ICIENEY REFERENCE - BNL INTERNAL DKTA

SATUIRATIIN REFERENCE- BNL. INTERNAL DATA

TECH FRA: REFERENCE- SAME AS UNIT DEMAND REFERENCE

SUBSECIOR- SIC 34

BASIS RE=ERENCE - USDOC. I976 ANNJUAL SURVEY OF MANUFACTURERS AND USDOC, ICURRENT SURVEY OF BUSINESSI(I976) UNIT DEMYND REFERENCE-USDOC, 11976 ANIJUAL SURVEY OF MANUFACTURES-FUELS AND ELEC ENERGY CONSUMED 1

EFF ICIENCY REFERENCE - BNL INTERNAL DATA

SATUIRATIJN REFERENCE - BNL INTERNAL DATA
TECH FRA:- REFERENCE - SAME AS UNIT DEMAND REFERENCE

SUBSECTOR- SIC 35

BASIJ REFERENCE- USDOC, 1976 ANFJUAL SURVEY OF MANUFACTURERS AND USDOC, ICURRENT SURVEY OF BUSINESSI(1976) UNIT DEMMND REFERENCE-USDOC, 1976 ANIJUAL SURVEY OF MANUFACTURES-FUELS AND ELEC ENERCY CONSUMED 1

EFF ICIENEY REFERENCE- BNL INTERNAL DATA

TECH FRAT: REFERENCE - SAME AS UNIT DEMAND REFERENCE 
SUBSECTOR- SIC 36

BAS IS ITEFERTCE

BASIS IT.TER.NCE- USCIOC, 1976 ANNUAL SURVEY OF MANUFACIURERS AND USDOC, ICURRENI SURVEY OF BUSINESSI (I976) UNII DEMAND REFERENCE - USCIOC . 1976 ANNUAL SURVEY OF MANUFACTUFES-FUELS AND ELEC ENERGY CONSUMEDI

CFF ICIENCY REFERENCE - BNL INIERNAL DATA
SATURATION REFERENCE - BNI INIERNAL DATA

TECH IFAC REFERENCE - SAME AS UNIT DEMAND REFERENCE

SUBSECTOR- SIC 37

BASIS REFERENCE:- USTOC, 1976 ANNUAL SURVEY OF MANUFACTURERS AND USDOC, ICURRENI SURVEY OF BUSINE.SSI(I976)

UNI1 DEMAND REFERENCE-UISCOC, 1976 ANNUAL SURVEY OF MANUFACTURES-FUELS AND ELEC ENERGY CONSUMEDI

EFF ICIEVCY REFLERENCE-- BNL IN'ERNAL DATA
SATURATION REFERENCE - BNL INTERNAL DATA

TECH FRAC REFERENCE- SAME AS UNIT DEMAND REFERENCE

SUBSECIOR- SIC 38

BASIS REFERE.NCE - USCOC. I976 ANNUAL SURVEY OF MANUF ACTURE.RS AND USDOC, ICURRENT SURVEY OF BUSINESS III976) UNI DEMAND REFERENCE-USCOC, 11976 ANNUAL SURVEY OF MANUFACTURES-FUELS AND ELEC ENERGY CONSUMEDI

EFF ICIENCY REFERENCE- BNL INTERNAL. DATA
SATURATION REFERENCE - BNL. INTERNAL DAIA

TECH FRAC REFERENCE - SAME AS UNIT DEMAND REFERENCE

SUBSECIOR- SIC 39

BASIS REFERENCE- USDOC, 1976 ANNUAL SURVEY OF MANUFACTURERS AND USDOC, ICURRENT SURVEY OF BUSINESS I11976, UNIT DEMAND REFERENCE-USDOC, 11976 ANNUAL SURVEY OF MANUFACTURES-FUELS AND ELEC ENERGY CONSUMEDI

EFF ICIENCY REFERENCE - BNL INTERNAL DATA
SA TURATION REFERENCE - BNL INTERNAL DATA

TECH FRAC REFERENCE - SAME AS UNIT DEMAND REFERENCE 
SECTOR-

$$
\text { IASIDENTIAL- }
$$

SUBSECTOF:- HIGH RISE.

BASI'S REFERENCE- NYSDCL 1 HOUSEHOLD PROLECIONS FOR NYS--19\%I AND IPOPILATION PROUNS FOR NYS--1978I

UNII DEMATND REFERLNCE-MODIF IED FOR NYS USINE A:G DEG DAYS AND DWELLIING SIZE FROM BNL. 'FUTURE RESVCOM ENERGY DEM IN THIE NE *

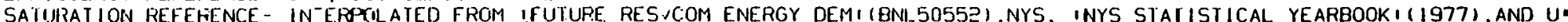
TECH FFAC REFERFENCE- USDOC, IMETAILED HOUSIMG CHARS--NYS, $19701+$ USDOC, ICHARS OF NEW HOUSINIS(1971-6) I WITH NYS CONSI DATA

SUBSEC ROP- LOW DENSITY

BASIS REFERENCE- NYSDOC. 1HOUSEHOLD PROJECTIONS FOR NYS--19781 AND IPOPULATION PROJNS FOR NYS--1978I

IUNI I DEMAND IREFERENCE-MODIFIEO FOR NYS USING AVG CIEG DAYS AND DWELIIING SIZE FROM BNL. IFUTURE RESVCOM ENERGY IJEM IN THE NE *

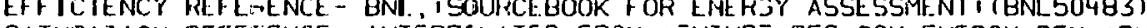

IECII FRAC IIEFERENCE - USDOC, IDE TAILED HOUDIMO USDOC ICHARS OF NEW HOUSINO $(1971-6)$, WITH NYS CONST DATA

\section{SUBSEC TOR:- LOW RISE}

BASIS REFERENCE- NYSOOC IHOUSEHOLD PZOJECTIONS EOR NYS--19781 AND IPOPULATION PROJNS FOR NYS--19781

UNII DEMAND REFERENCE-MODIFIED FOR NYS USING AVG DEG DAYS ANIJ DWELL ING SIZE FROM BNL. IFUTURE RESVCOM ENER(IY DEM IN THE NE. EFFICIENCY RE.FEFENCE - BNA , ISOURCEBOOK FOR EMERS Y ASSESSMENTI (BNL.50483)

TECH (

\section{SUBSECIOR- MOB.LLE HOMES}

BASIS REFERENCE- NYSOOC. IHOUSEHOLD PROJECTIONS TOR NYS--1978, AND IPOPULATION PROJNS FOR NYS--1978I

UNI I DEMAND REF ERENCE-MODIF. IE.D FOR NYS USING AVG DEG DAYS AND DWELL. ING SIZE FROM BINL. IFUTUFE RESUCOH ENERGY DEM IN THE NE * EFF TCIENCY REFE -ENCE- BNL,

SAT JRATON REFE.ENCE - INTERFOLATED FROM FUTURE TECH FPAC REFERENCE- USJOC. IDETAILED HOUSIHG CHARS--NYS, $19701+$ USDOC, ICHARS OF NEW HOUSINOII97I-6II WITH NYS CONST DATA

SUBSEC TOR- SINGILE FAMILY

BASI'S REFERENCE- NYSDOC, IHOUSEHOLD PROJECTIONS FOR NYS--1978I AND IPOFULATION PROJINS FOR NYS--1978I

UNIT DEMAND FEFERENCE-MOJIFIED FOR NYS USING AVO DEG DAYS AND DWEL.LING SIZE FROM BNL. IFUTUFE RESVCOM ENERGY DEM IN THE NE. EFFICIENCY REFERENCE- BNL. 'SOURCEBOOK FOF EINEFGY ASSESSMENTI (BNL50483)

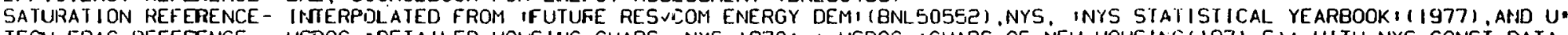
TEOI FRAC REFEREIICE- USDOC. IDETAILED HOLSING CHARS--NYS, $19701+$ USDOC, ICHARS OF NEW HOUSING I $1971-6) 1$ WITH NYS CONST DATA 


\section{SUBSECTIOR- AIR HRE IGHII}

BASIS REFERENCE - RESIOUAL FROM MOTOR FUEI CONSUMP IN NYS. ABTRACTEO FROM I976 FEOERAL HIGHWAY ADMIN DATA

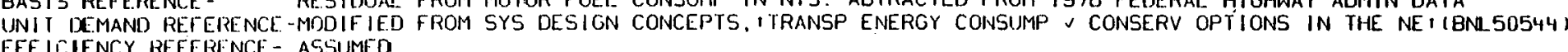
EFFICIENCY REFERE:NCE- ASSUMED

SACURATRA RETERENCE. SAME AS BASIS REFERENCE

\section{SUBSECTOR- AIR PASS}

BASIS RLFEIRI:NCEUNII OCMAND REFERENCE.-MODIF IED FROM. SYS DESIGIN CONCEPIS, I TRANSP ENERGY CONSUMP $\checkmark$ CONSERV OPTIONS IN THE NEI (BNA 50544 II EFF COITNCY REFERENCE - ASSUMED

EFF VCITNCY REFERENCE - ASSUIUE

SATURATION REFERENCE- ASSUMED BAIS REFERENCE

SUBSECTOR- AUTO

USOOT IHIGHWAY STATS 19751 AND NYSDOT IAUIO ENERGY USE-- A BASELINE PROIN FOR NYSIPPRI33II

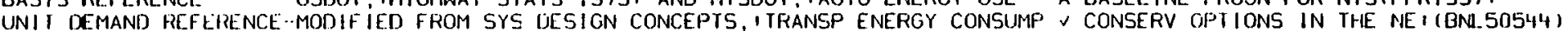

EFF にIENCY REFERENCE- ASSUMED

SATCH TRAC RLFERTNCE- SAME AS BASIS REFERENCE

\section{SUBSECIOR- BUS}

BASIS REFEFENCE- RESIDUA FROM MOTOR FUEL CONSUMP IN NYS. ABIRACTED FROM 1976 FEDERAL HIGIINAY ADMIN DATA

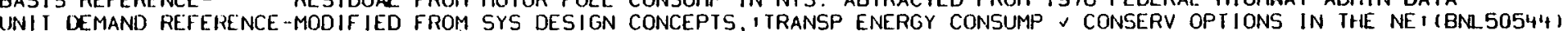
EFFICIENCY REFERENCE- ASSUMED

TECH FRAC REFERENCE - SAME AS BASIS REFERENCE

\section{SUBSECIOR- RAIL}

BASIS REFERENCE- $\quad$ ELECTRICITY CONSUMPIION FOR TRANSPORI FROM NYPP $149-8$ REFORI 119771

UNIT DEMAND REFERENCE-MODIF IED FROM SYS DESION CONCEPTS, ITRANSP ENERGY CONSUMP $\checkmark$ CONSERV OPTIONS IN THE NE I(BNR 5054,1$)$ EFF ICIENCY REFERENCE - ASSUMED

SATURATION REFERENCE- ASSUMED -

SUBSECTOR- RAIL FREIGHT

BASIS REFEIRENCE- ELECIRICITY CONSUMPIION FOR TRANSPORT FROM NYPP 11,9-B REPURT 119771

UNIT CEMAND REFERENCE-MODIF IED FROM SYS DESIGN CONCEPTS, ITRANSP ENERGY CONSUMP $\checkmark$ CONSERV OPTIONS IN THE NE I (BNLSOSH') EFF I IIENCY REFERENCE - ASSUMED

TECH FRAC REFERENCE - SAME AS BASIS REFERENCE

SUBSECTCR- TRUCK

BASIS REFERENCE- RESIDUAL FROM MOIOR FUEL CONSUMP IN NYS. ABTRACTED FROM 1976 FEDERAL HIGHWAY ADMIN DATA

UNII DEMAND REFERENCE-MODIF IED FROM SYS DESIGN CONCEPTS, ITRANSP E.NERGY CONSUMP $\checkmark$ CONSERV OPTIONS IN THE NEII(BNL50544) EFF LIENCY REFERENCE- ASSUMEC

SATURATION REFERENCE- ASSUMED 
IECH FFAC FEFERENCE- SAME A.S BASIS FLFERENCE

\section{SUBSECTOH- HATER}

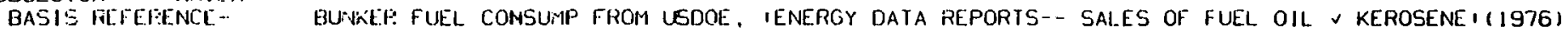

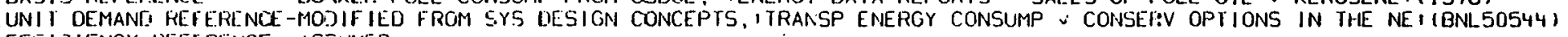

EFFICIENCY REFERENCE- ASSUMED
SATUFATION REFERENCE- ASSUMED

TECH FFIAC PEFERENCF- SAME GS BASIS FEFERENCE 
ACRICUL TURE

SCENARIO- BASTE CASE $4 / 01 / 79$ YEAR- $19 \%$

苦

SUGSECTOR GENERAL

END-USE EIECTRICITY
UNIT DEMAND 30.71 SATUFATION 1.000

58.00 IE 3 FAFMS

TECHNOLOGY FUEL

E.ECTRICITY

ELECTRICITY TECH FRAC

$\begin{array}{rrr}58.00 & 1.00 & 1781.2\end{array}$

\section{SUBSECILR GENERAL}

END-USE PROPANE

UNII DEMAAND

BASIS

TECHNOLCOY

PROPANE:

FUEI.
OIL

10.91 SAIUFATION

IE3 FAFIMS

ECH FRAC
E 8.00

1.000

$\begin{array}{lr}.65 & \text { FUEL_DEM } \\ & 973.5\end{array}$

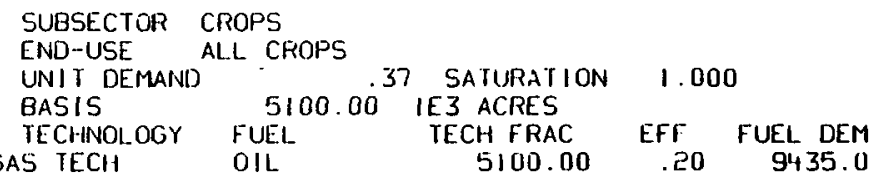

SUESECTOR LIVESTOCK

END-USE, ALL STOCK 17 SATURATION 1.000

BASIS

BASIS

2095.00 17 SATURAT HEAD

IE 3 HEAD
TECH FRAC

TECHNOLOGY FUE

2095.00

EFF FUEL DEM 


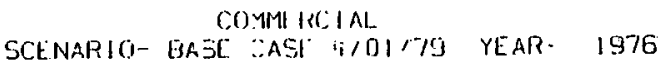

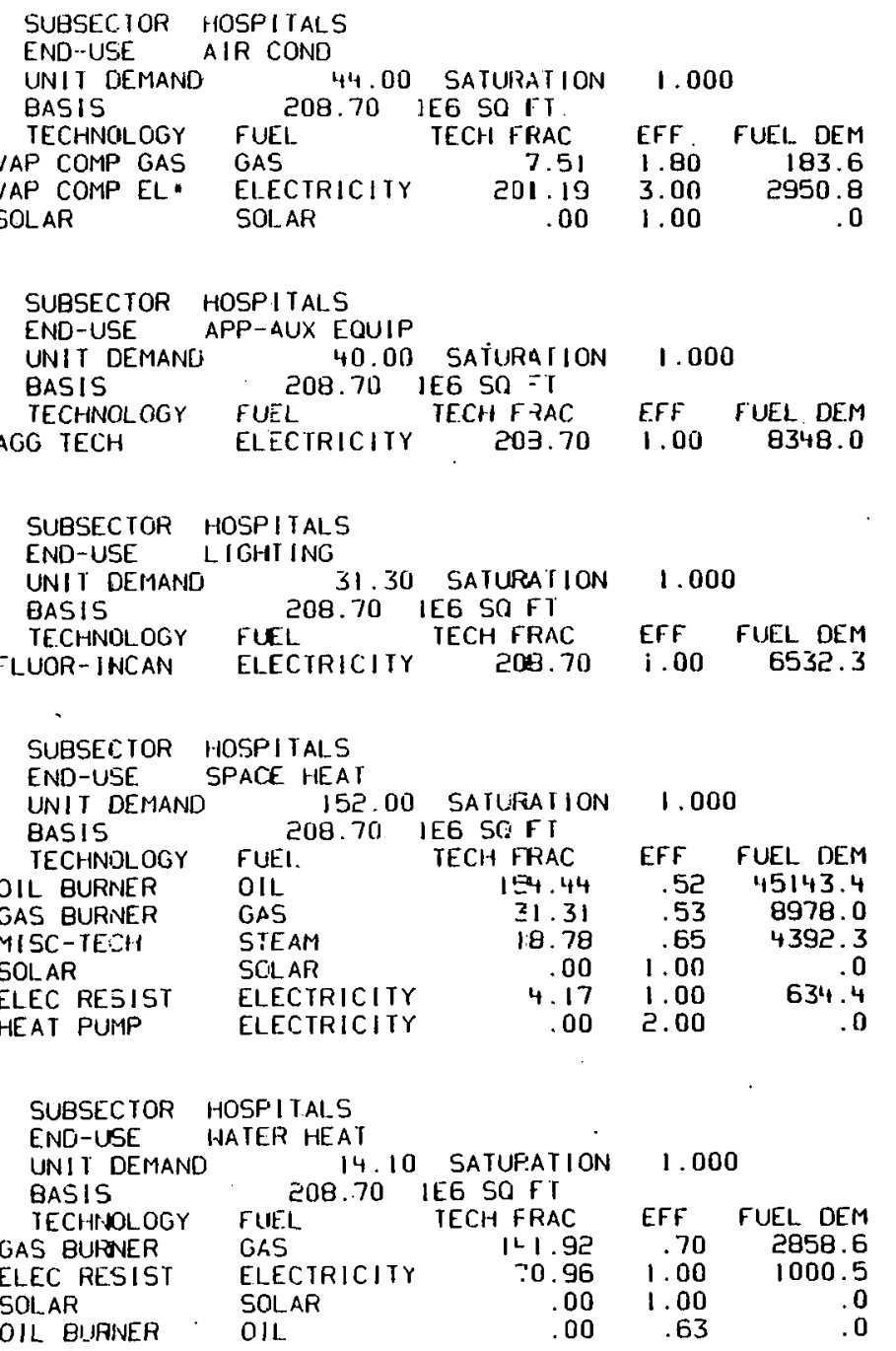



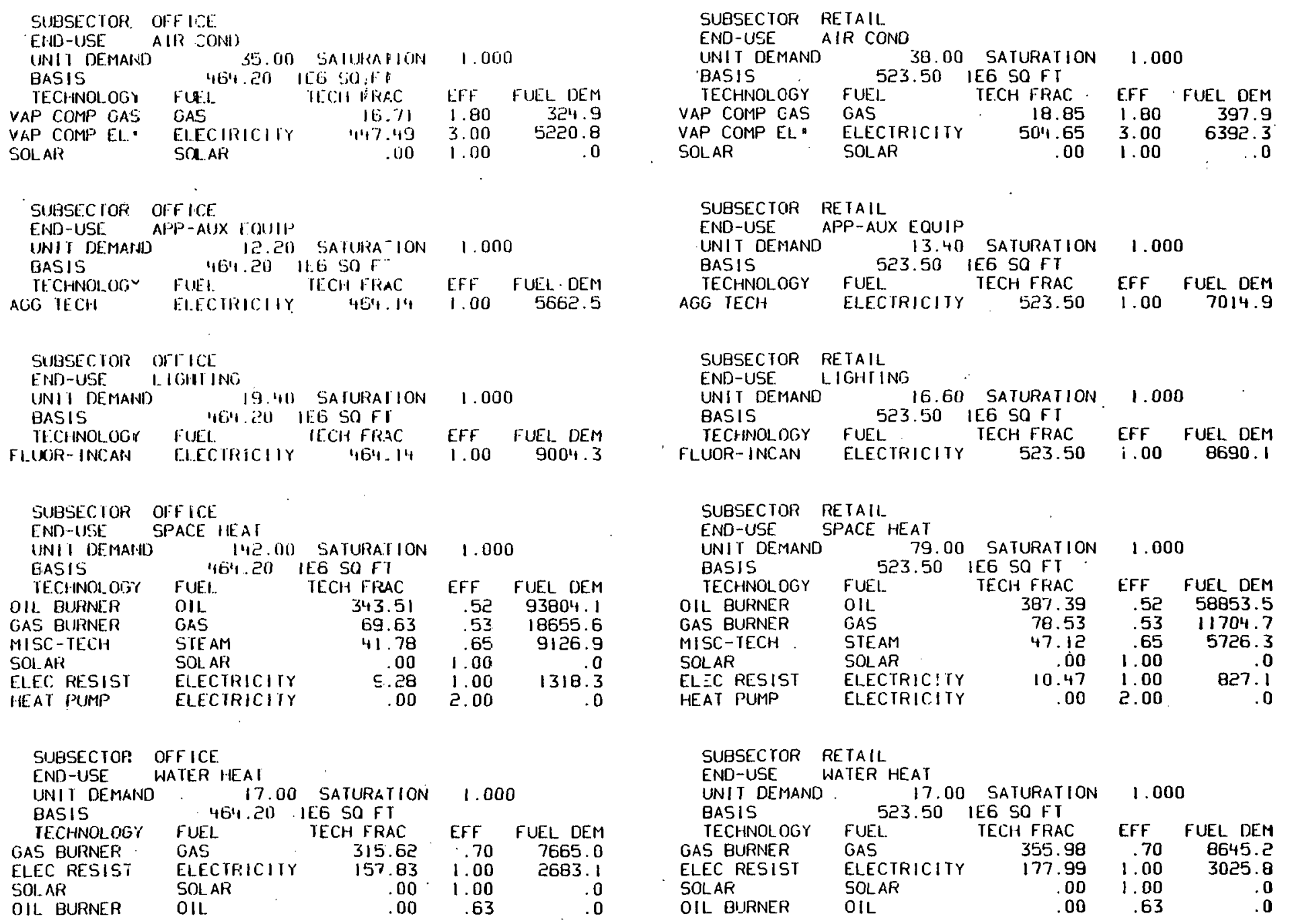

\begin{tabular}{llllll} 
SUBSECTOR & RETAIL & & & \\
END-USE & WATER HEAT & & & \\
UNIT DEMAND. & \multicolumn{1}{c}{17.00} & SATURATION & 1.000 & \\
BASIS & 523.50 & IEE SO FT & & \\
TECHNOLOGY & FUEL. & TECH FRAC & EFF & FUEL DEM \\
GAS BURNER & GAS & 355.98 & .70 & 8645.2 \\
ELEC RESIST & ELECTRICITY & 177.99 & 1.00 & 3025.8 \\
SOLAR & SOLAR & .00 & 1.00 & .0 \\
OIL BURNER & OIL & .00 & .63 & .0
\end{tabular}




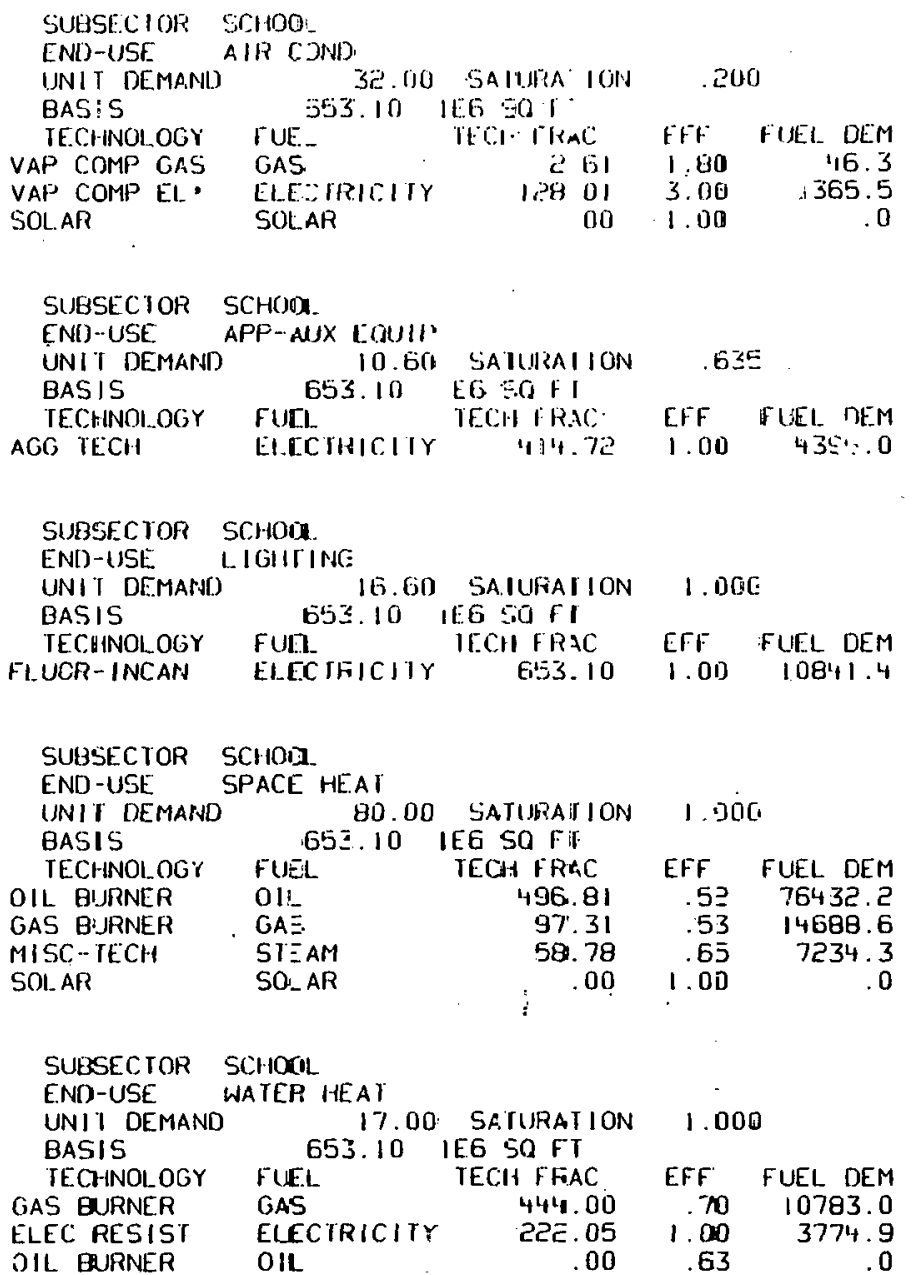

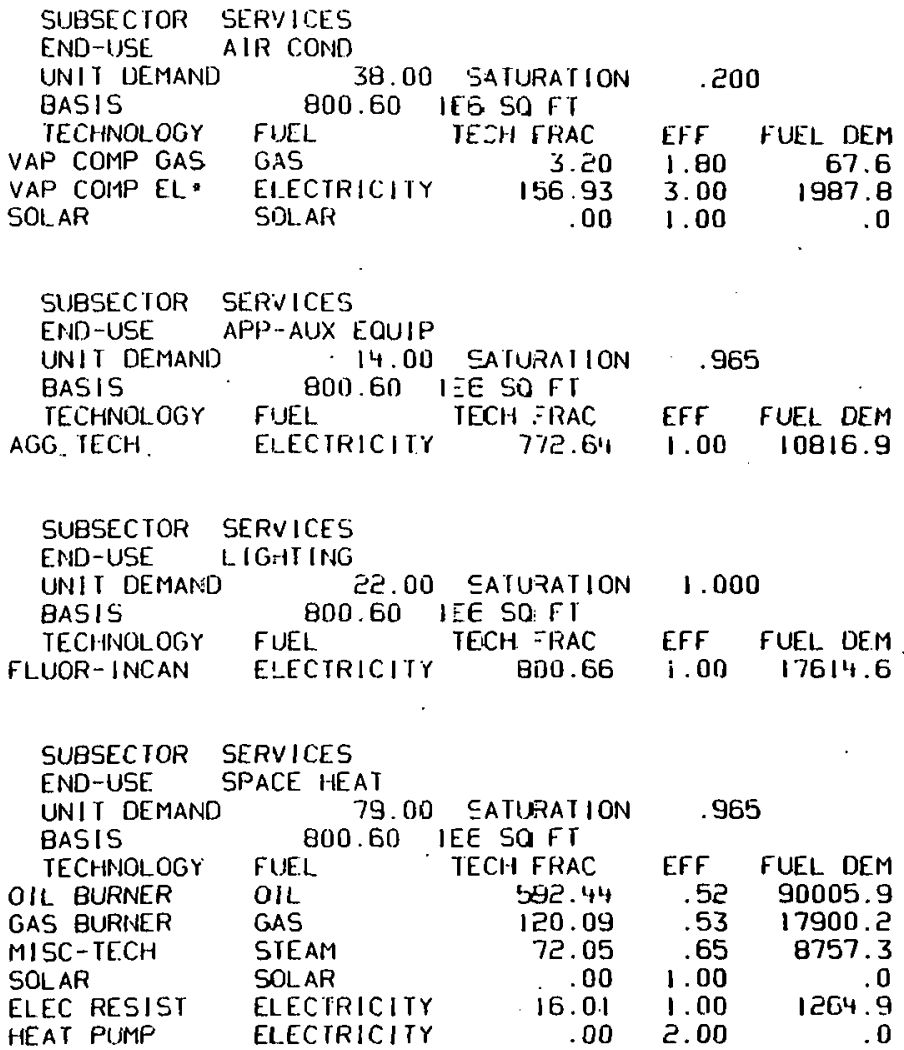


GOVERNMENT

SCENARIO- BASE CASE $4 / 01 / 79$ YEAR- $19 \%$

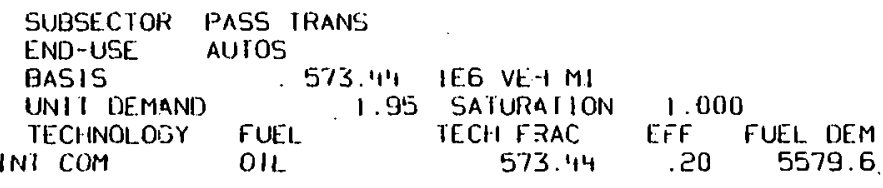

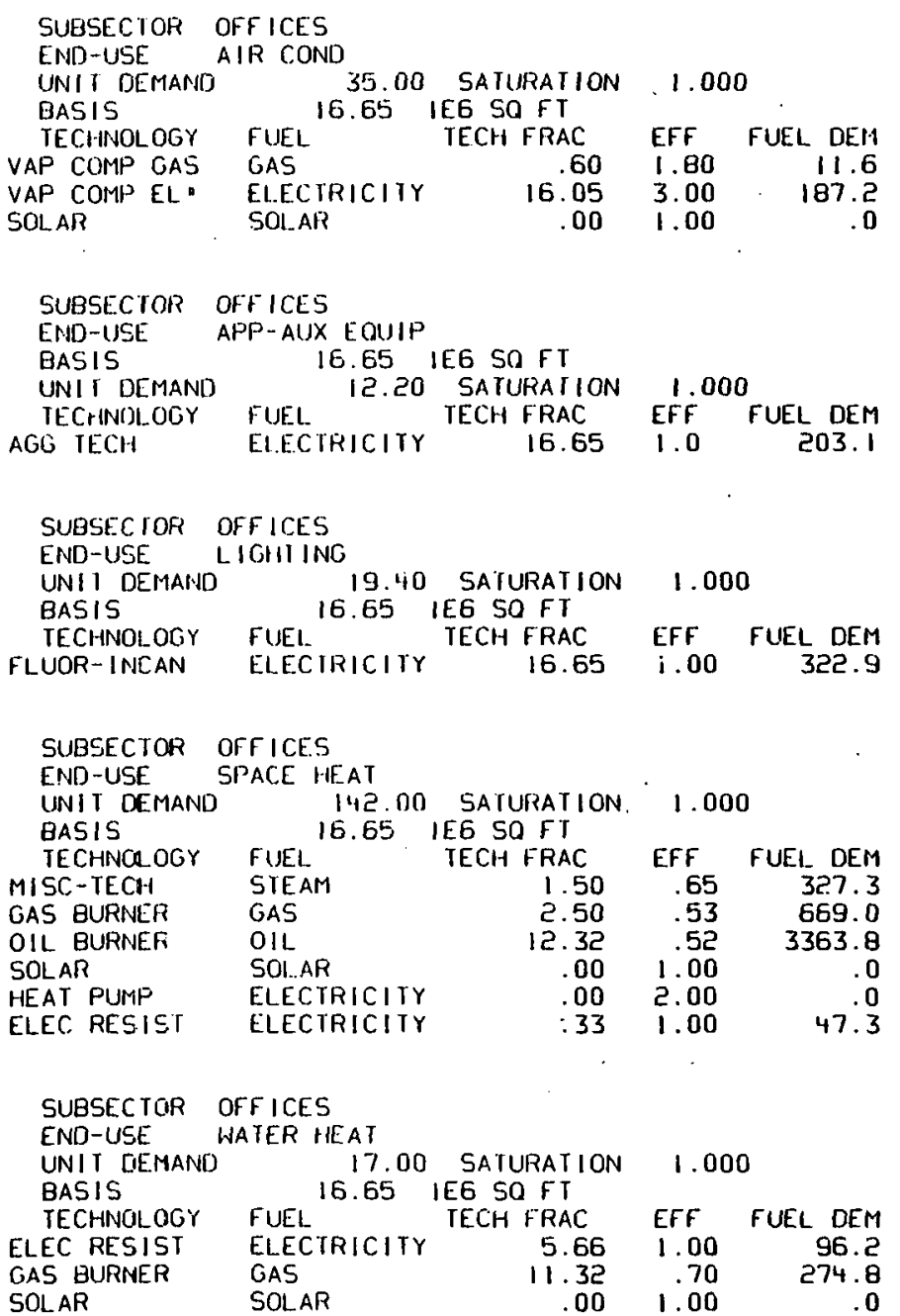


MANUJ" ACIUREING

SCENAFIO- BASE CAST '/3I/79 YTAR 1976

SUBSECTOR SIC $=0$

ENIJ-USE ELEC DRIVL

UNIT DOEMAND

BASIS 155.08 \& MIIL VAI ADI) (6\%9)

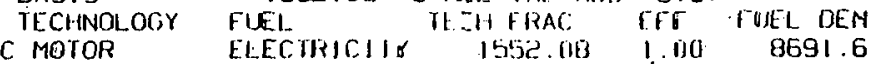

SUBSECTOR SIC 20

E.ND-USE. PROOISS HE:AI

UNIT DEMAND H.OH SAIURATION I.000

BASIS I5EZ.08 \$ MIL VAL ADO $167 \%$

TECHNOLOGY FUEL TECH FRAC EFF FIJEL DEM

COAL BURINER CIAL

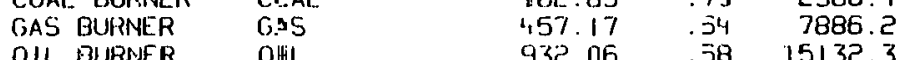

站

$\begin{array}{llll}\text { DIL. BURNER OHL } & 932.06 & .38 & 15132.3\end{array}$

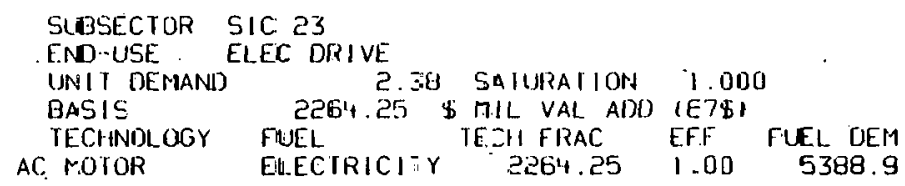

OAL BURNER

FUSEL
C.JAL
G:S

.00

B31
432.43
432.32

70
.64
68

415.7

OIL. BURNER

OIL

1432.32

674.3 
SUBSECTOR SIC 25

END-USE ELEC DRIVE

UNIT DEMANJ 3.00 SATURATION 1.000

BASIS 288.27 \& MII YAL ADD 167\%

TECHNOLOGY FUEL TECH FRAC EFF FUEL DEM

AC MOTOR BLECTRICITY $288.27 \quad 1.00$ 864.8

SUBSECTOR SIC 25

ENB-USE PROCESS HEAT

UNIT DEMANO 4.25 SATURATION 1.000

TECHINOLOGY FUEL

COAL BURNER COAL

GAS BURNER GAS

GAS

ECH FRAC

71.07
92.57

$.70 \quad 431.5$

OIt

121.63

614.7
778.9

空
SUBSECTOR SIC 26

END-USE ELEC DRIVE

UNIT DEMAND 15.06 SATURATION 1.000

BASIS 615.18 $\$$ MIL VAL ADD (67\%)

TECHINOLOGY FUEL TECH FRAC EFF FUEL DEM

$\begin{array}{llll}\text { AC MOTOR } & 615.18 & 1.00 & 9264.6\end{array}$

SUBSECTOR SIC 26

END-USE PROCESS HEAT

UNIT DEMAND 10.49 SATURATION 1.000

BASIS 615.18 \$ MIL VAL. ADO (67\$)

TECHNOLOGY FUEL TECH FRAC EFF FUEL DEM

$\begin{array}{lllll}\text { COAL BURNER COAL } & 100.59 & .70 & 5818.4\end{array}$

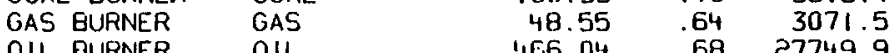

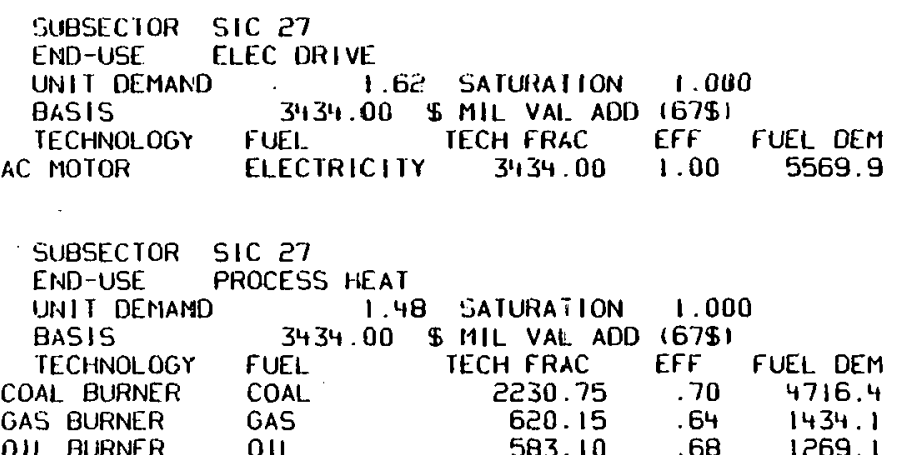

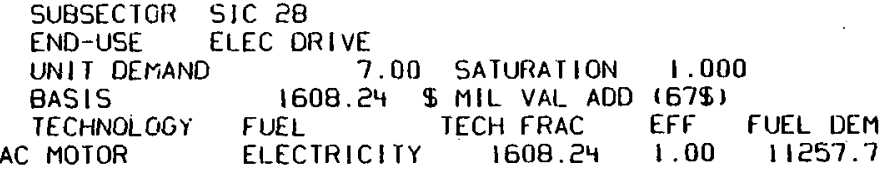

$\begin{array}{llll}\text { OIL BURNER OIL } & 652.66 & .68 & 21633.8\end{array}$



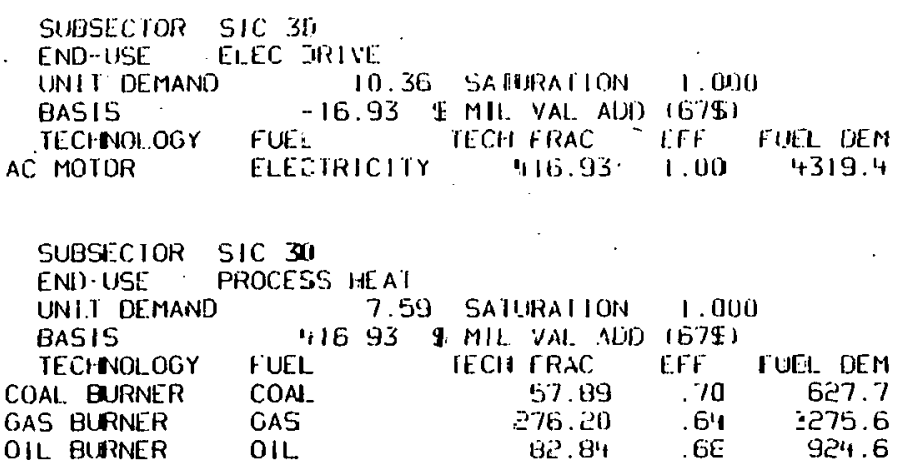
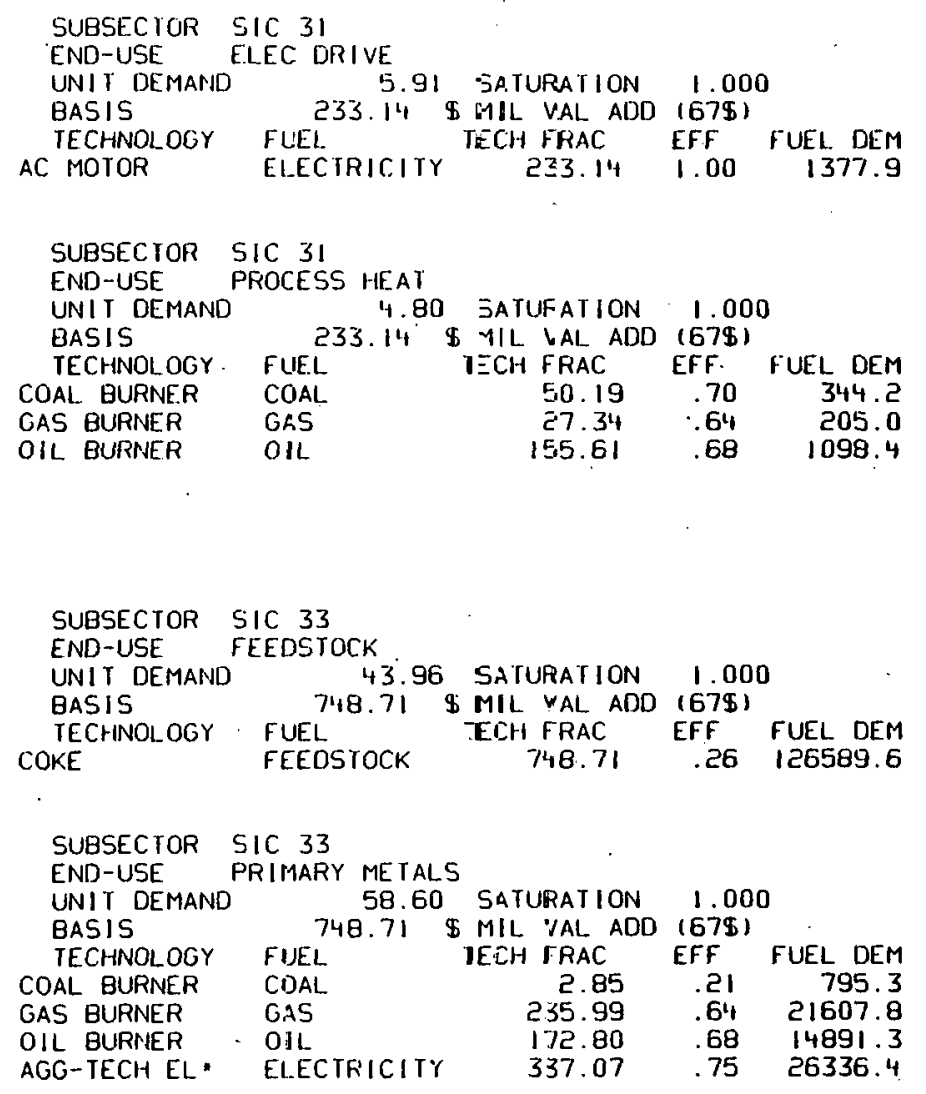


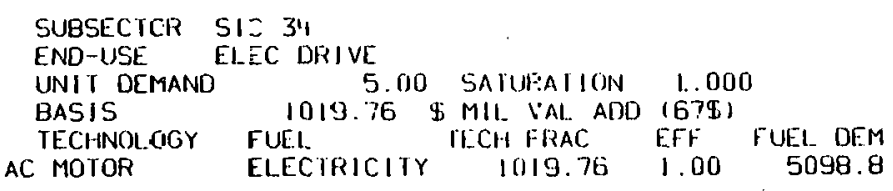

\section{SUBSECTOR SIC 3}

END-USE PROCESS HEAT

UNIT DEMAND 6.19 SATURATION 1.000

BASIS 1019.76 \$ MIL $\checkmark A L$ ADD $167 \$ 1$

TECHINOLOGY FUEL TECI FRAC EFF FUEL DEM

$\begin{array}{lllll}\text { COAL BURNER COAL } & 193.97 & .70 & 1798.4\end{array}$

$\begin{array}{lllll}\text { GAS BURNER } & \text { GAS } & 193.97 & .70 & 1798.4 \\ \text { OIL BURNER } & \text { OIL } & -651.56 & .64 & 4710.9 \\ & & & & 34147.7\end{array}$

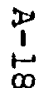

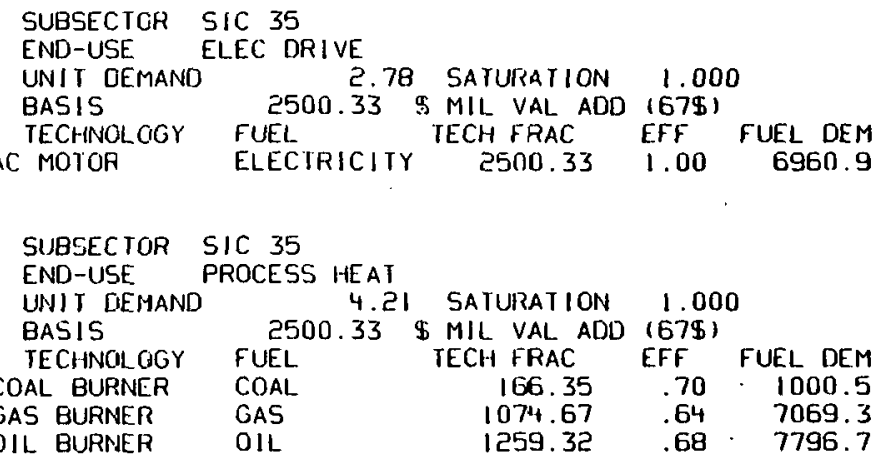

OIL BURMER

OIL

1259.32

7796.7

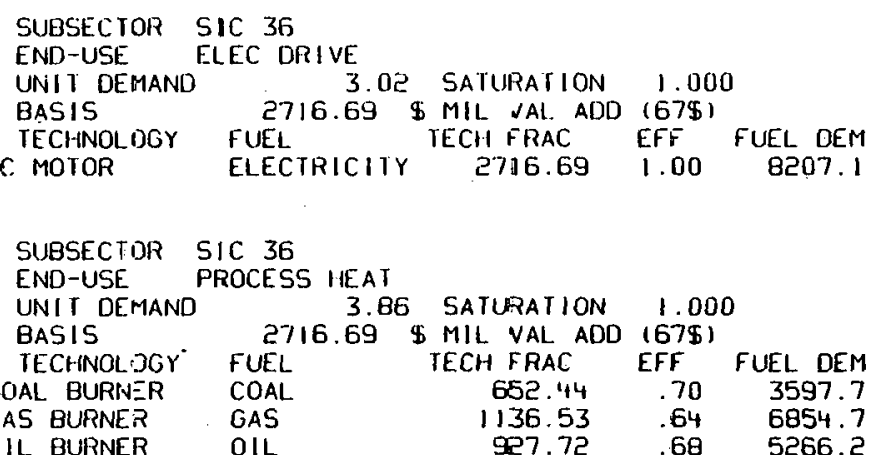

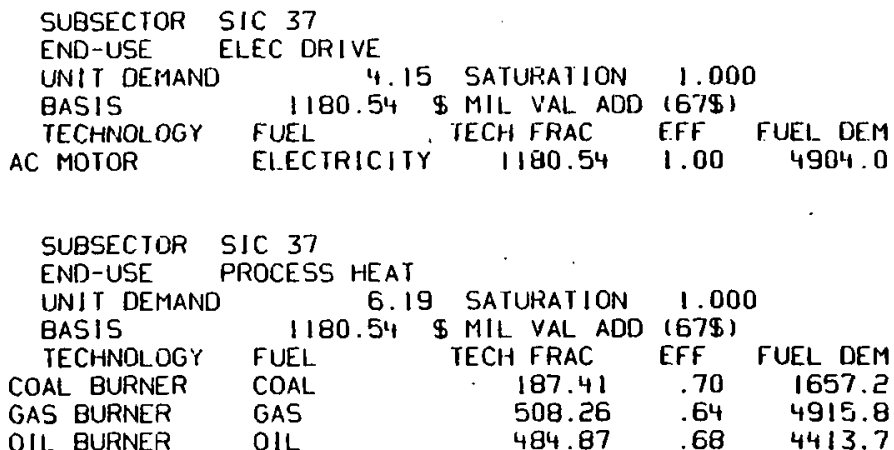



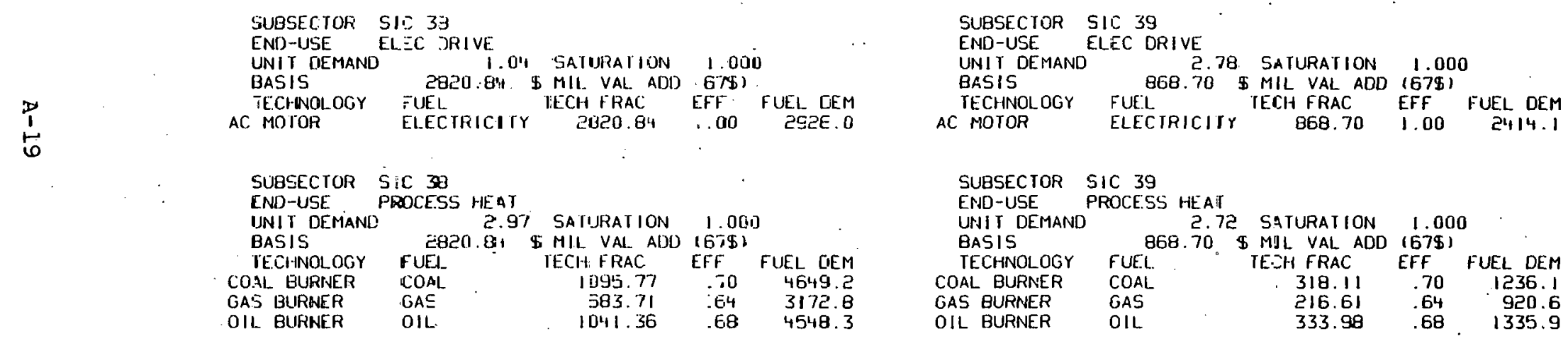
IUSIOENI IAL.

SCENARIO- BASE: CASE $4 / 01 \% 9$ YEAR- 1976

\begin{tabular}{|c|c|c|c|c|}
\hline $\begin{array}{l}\text { SUBSE.CTOR } \\
\text { END-USE }\end{array}$ & $\begin{array}{l}\text { IGH RISE } \\
\text { IR COND }\end{array}$ & & & \\
\hline UNIT DEMAND & 5900.00 & SATURATI & .6 & \\
\hline BASIS & 1.47 & IEG HOUSEH & & \\
\hline TECHNOLOGY & FUEL & TECH FRAC & EFF & FUEL DEM \\
\hline OM & ELECTRICITY & & & 2003.1 \\
\hline ZAL & ELECTRICITY & .0 & 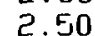 & 606.5 \\
\hline SOLAR & SOLAR & .0 & 1.00 & \\
\hline
\end{tabular}

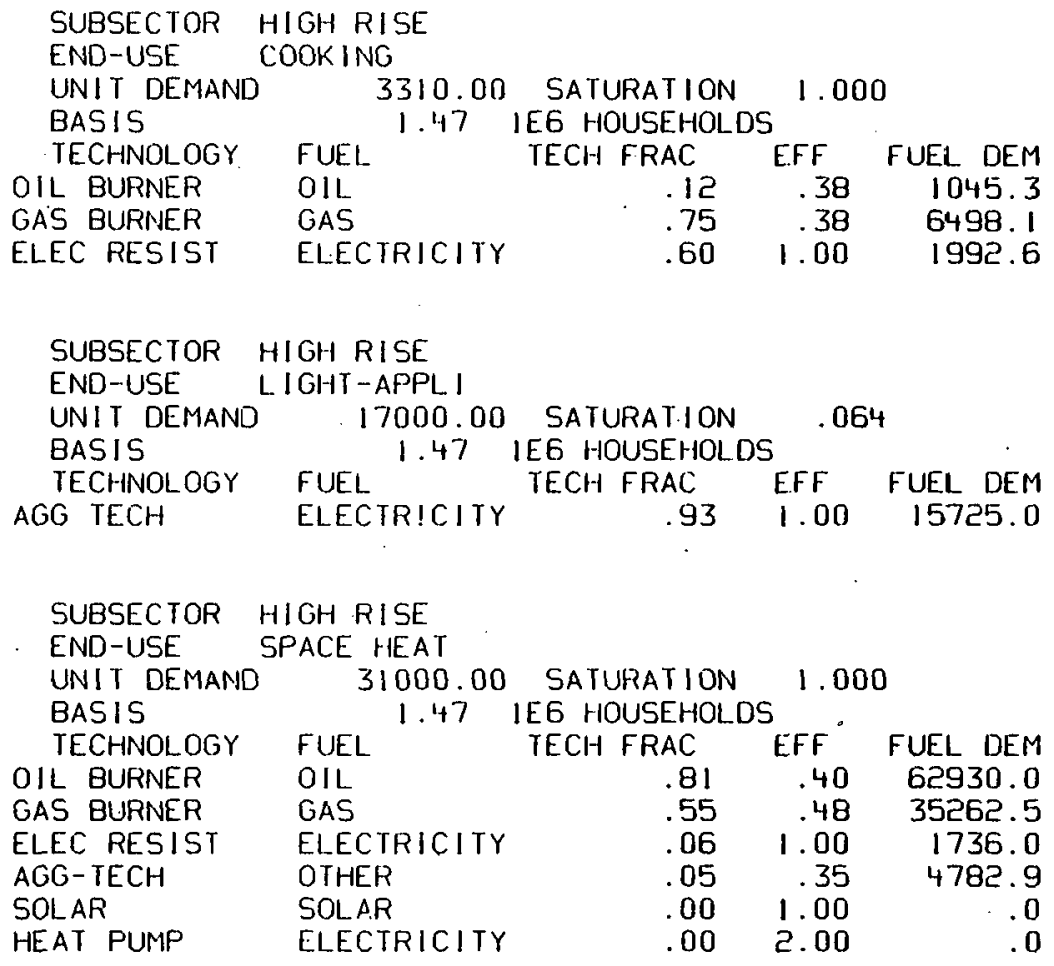

$\begin{array}{ll}\text { SUBSECTOR } & \text { HIGH RISE } \\ \text { END-USE } & \text { WATER HEAT }\end{array}$

\begin{tabular}{|c|c|c|c|c|}
\hline $\begin{array}{l}\text { END-USE } \\
\text { UNI'T DEMAND } \\
\text { BASIS }\end{array}$ & $\begin{array}{c}\text { ER HEAT } \\
12283.00 \\
1.47\end{array}$ & $\begin{array}{l}\text { SATURAT } \\
\text { IEG HOUSEH }\end{array}$ & 1.0 & \\
\hline NOLOGY & FUEL & TECH FRAC & EFF & FUEL \\
\hline & OIL & & & 13 \\
\hline & & & & $1591^{\circ}$ \\
\hline & & & 1. & \\
\hline & SOLAF & 0 & 1.00 & \\
\hline
\end{tabular}




\begin{tabular}{|c|c|c|c|c|}
\hline $\begin{array}{l}\text { SUIBSECIOR } \\
\text { END-USE }\end{array}$ & $\begin{array}{l}\text { L.OW DENSIIY } \\
\text { AIR CONID }\end{array}$ & & & \\
\hline UNIT DE.TAND & 5900.00 & 0 S.AIUFATION & 638 & \\
\hline BAS IS & 1.41 & IEG HOLSEHOL DS & & \\
\hline TECHNOLOGY & FUEI & TECH FRAC & EFiF & FUE! DEM \\
\hline ROOM & ELECTRICITY & .65 & 2. 00 & 1923.4 \\
\hline CENTRAL & ERECTRICITY & .25 & 2.50 & 582.9 \\
\hline SOLAR & SOLAR & .00 & 1.00 & .0 \\
\hline $\begin{array}{l}\text { SUBSECIOR } \\
\text { END-USE }\end{array}$ & $\begin{array}{l}\text { LOH DENSITY } \\
\text { COCK ING }\end{array}$ & & & \\
\hline UNIT DEMAND & 3310.00 & 0 SATUF:ATION & 4.050 & \\
\hline BASIS & 1.111 & IEE. HOUSEHCLOS & & \\
\hline TECHNOLOGY & FOJEL & TECH FRAC & E.FF & FUEL DEM \\
\hline OIL BURNER & CIL & I & .38 & 1010.4 \\
\hline CAS BUIRNER & CaS & 72 & .38 & 6236.7 \\
\hline EIEC RESIST & ELECIRICITY & .58 & 1.00 & 1913.2 \\
\hline
\end{tabular}

TECHNOLOGY FIJEL TLCH FRAC EFF FUEL DEM

\begin{tabular}{|c|c|c|c|c|}
\hline $\begin{array}{l}\text { SUBSEC IOR } \\
\text { END-USE }\end{array}$ & $\begin{array}{l}\text { LoW RISE } \\
\text { AIR CONDI }\end{array}$ & & & \\
\hline UNIT DEMAND & 5900.00 & SATURATIO & 6 & \\
\hline BASIS & .83 & IEG HOUSEHC & & \\
\hline IECHNOLOSY & FUEL & TECH FRAC & EFF & FUEL DEM \\
\hline ROON & EIECTRICITY & .38 & 2. 00 & 1126.9 \\
\hline CENTRAL & ELECTRIC ITY & .11 & 2.50 & 339.8 \\
\hline SOLAR & SOL_AR & .00 & 1.00 & 0 \\
\hline
\end{tabular}

\section{SLBSECTOR LOW RISE \\ END-USE COOKING}

UNIT DEMAND 3310.00 SATURATION 1.000

BASIS

FUEL TECII FRAC EFF FUEL DEM $\begin{array}{llll}\text { OIL BURNER OIL } & .07 & .38 & 592.3\end{array}$ $\begin{array}{lllll}\text { GAS BURNER } & \text { GAS } & .42 & .38 & 3649.7 \\ \text { ELEC RESIST } & \text { ELECTRICITY } & .31 & 1.00 & 1118.8\end{array}$

\section{SUBSECTOR LOW RISE}

$\begin{array}{ll}\text { SUBSECTOR } & \text { LOW RISE } \\ \text { END-USE } & \text { LIGHT-APPLI }\end{array}$

UNDIT DEMAND 17000:00 SATURATION .630

UNIT DEMAND 17000.00 SATURATION .630

TECHNOLOGY FUEL. 83 TECH FRAC EFF FUEL DEM

$\begin{array}{crrrr}\text { TECHNOLOGY FUEL } & \text { TECH FRAC } & \text { EFF } & \text { FUEL DEM } \\ \text { AGG TECH } & \text { ELECIRICITY } & .52 & 1.00 & 8840.0\end{array}$

SUBSECTOR LOW DENSITY

\begin{tabular}{|c|c|c|c|c|}
\hline \multicolumn{2}{|r|}{ PIDF HEAI } & & & \\
\hline NII DEMAND & 50000.00 & EATIJRATIK & $\therefore a$ & \\
\hline BASIS & 1.41 & IEE HOUSEHI & & \\
\hline TECHNOL_OGY & F JEL & TECH IRAC & EFF & FUEL DEM \\
\hline II BUURNER & oil & .8 & 40 & 100625.0 \\
\hline BUIRNER & GAS & .5 & $4 E$ & 55729.2 \\
\hline C RESIST & ELECTRICITY & 0 & 1.00 & 1000.0 \\
\hline- TECH & OTHER & 0 & 35 & 7142.9 \\
\hline $1.2 R$ & SOL AR & .0 & 1.00 & 0 \\
\hline . & ELECTRICITYY & .0 & $2.0 \mathrm{c}$ & 0 \\
\hline
\end{tabular}

SUBSECTOR LOH DENSITY

\begin{tabular}{|c|c|c|c|c|}
\hline $\begin{array}{l}\text { END-USE } \\
\text { UNI T DEMANU }\end{array}$ & $\begin{array}{l}\text { A.TER HEAT } \\
12283.00\end{array}$ & SATURATIO & I. Ere & \\
\hline BASIS & 1.41 & IEG HOUSEHO & & \\
\hline TECHNOLOGY & FUEL & TECH $=\mathrm{RAC}$ & EFF & FUEL DEM \\
\hline IL BURNER & $E I L$ & .68 & .63 & 13199.4 \\
\hline $\begin{array}{l}S \text { BURNER } \\
\text { ES RESIS }\end{array}$ & EAS & .71 & -5. & 15192.1 \\
\hline LAR & OOLAR & .00 & 1.00 & D \\
\hline
\end{tabular}

\begin{tabular}{|c|c|c|c|c|}
\hline $\begin{array}{l}\text { SUBSECTOR } \\
\text { END-USE } \\
\text { UNIT DEMAND }\end{array}$ & $\begin{array}{l}\text { LOW RISE } \\
\text { SPACE HEAT } \\
33000.00\end{array}$ & SAIURATION & 1.00 & \\
\hline BASIS & .83 & IEG HOUSEHOLDS & & \\
\hline TECHNOLOGY & FUEL & TECH FRAC & EFF & FUEL DEM \\
\hline OIL BURNER & OIL & .45 & .40 & 37372.5 \\
\hline GAS BURNER & GAS & .31 & .48 & 21037.5 \\
\hline ELEC RESIST & EIECTRICITY & .04 & 1.00 & 1155.0 \\
\hline$A G G-T E C H$ & OTHER & .03 & .35 & 2922.9 \\
\hline SOLAR & SOLAR & .00 & 1.00 & .0 \\
\hline HEAT PUMP & ELECTRICITY & .00 & 2.00 & 0 \\
\hline
\end{tabular}

$\begin{array}{ll}\text { SUBSECTOR } & \text { LOW RISE } \\ \text { END-USE } & \text { WATER HEAT }\end{array}$

END-USE WATER HEAT
UNIT DEMAND IZ2B3.00 SATURATION 1.000

$\begin{array}{cc}\text { UNIT DEMAND } 12283.00 \text { SA TURATION I } \\ \text { BASIS } & .83 \text { IEG . HOUSEHOLOS }\end{array}$

IECHINOLOGY FUEL 83 TEC - FRAC EFF FUEL DEM

$\begin{array}{rlrrr}\text { TIECHNOLOGY } & \text { FUEL } & \text { TEC T FRAC } & \text { EFF } & \text { FUEL DEM } \\ \text { OIL BURNEF } & \text { OIL } & .40 & .63 & 7720.7 \\ \text { GAS BURNER } & \text { GAS } & .41 & .57 & 8878.2\end{array}$

$\begin{array}{llrrr}\text { GAS BURNER } & \text { GAS } & .41 & .57 & 8878.2 \\ \text { ELEC RESIST } & \text { ELECTRICITY } & .02 & 1.00 & 208.8 \\ \text { SOLAR } & \text { SOLAR } & .00 & 1.00 & .0\end{array}$$$
\text { (1) }
$$ 


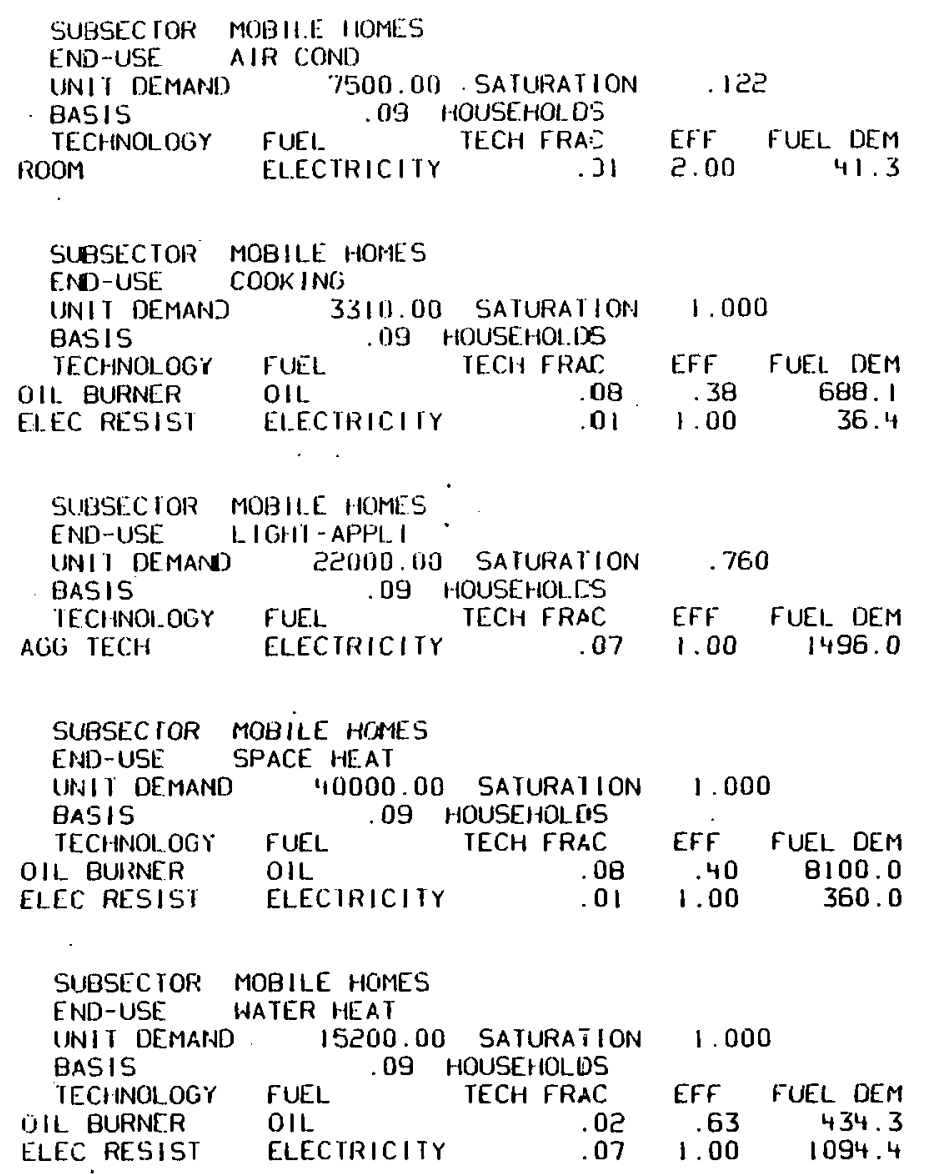


TRANSPOF:T
SCENARIO- BASE CASE L/O1;79 YEAR- 1976

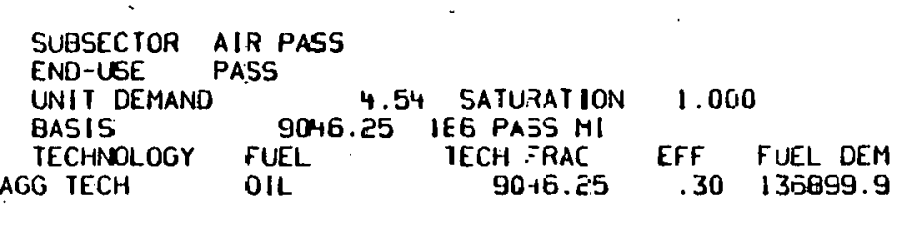

$\underset{n}{1}$

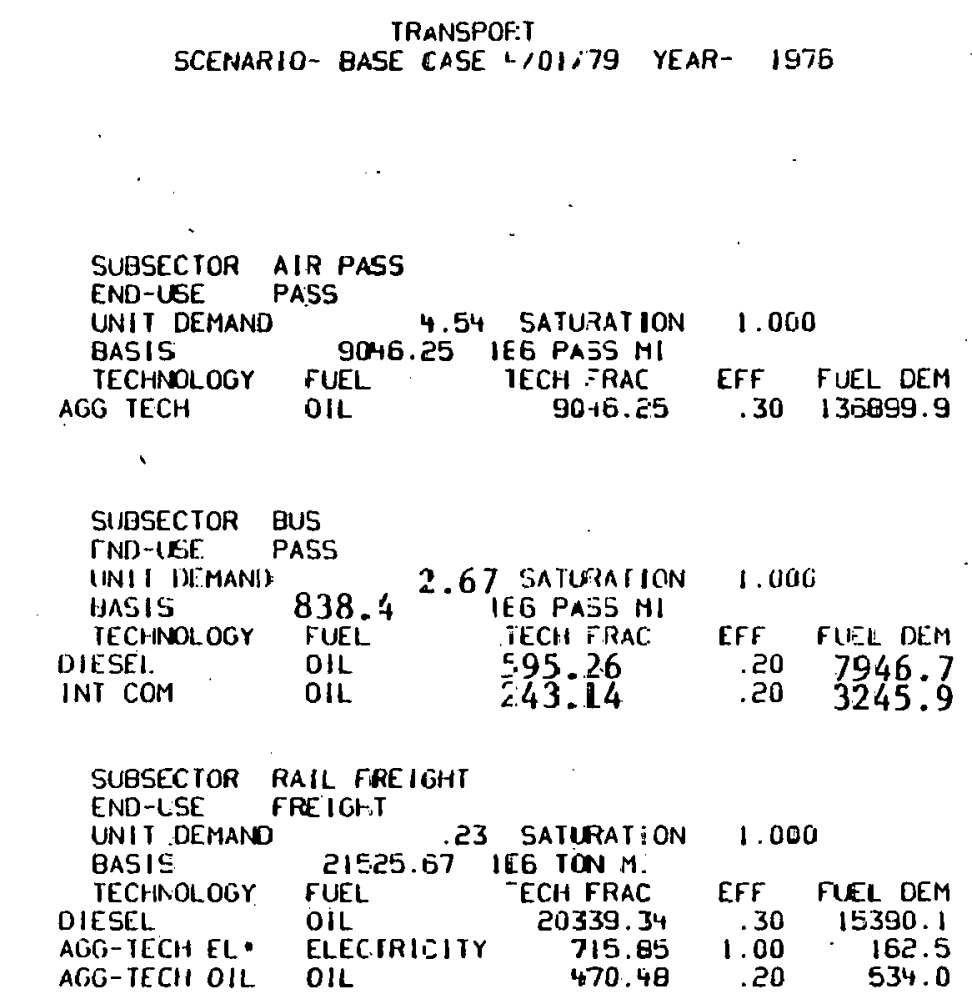

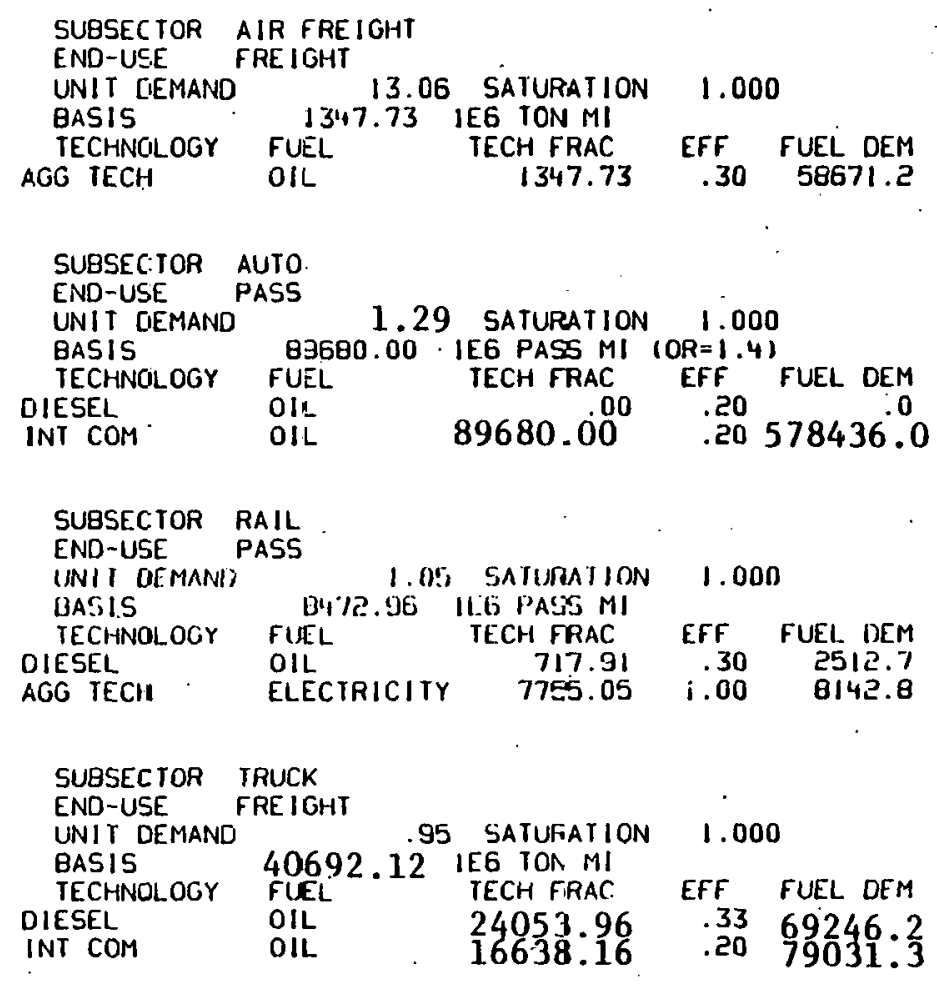

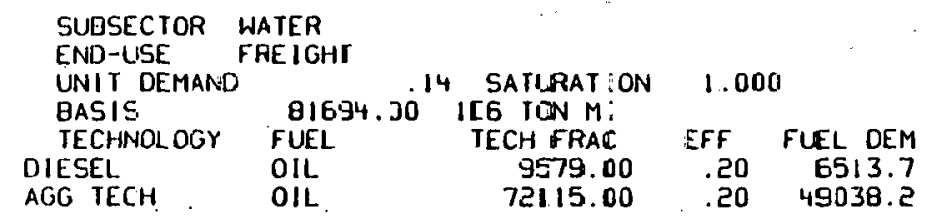


$+$

3

TABLE 2
APPENDIX A

ENERGY DEMAND AND FUEL MI

SCENARIO- BASE CASE 4/79 YEAR- 1976

RUN DATE -APR 06, 1979

. 


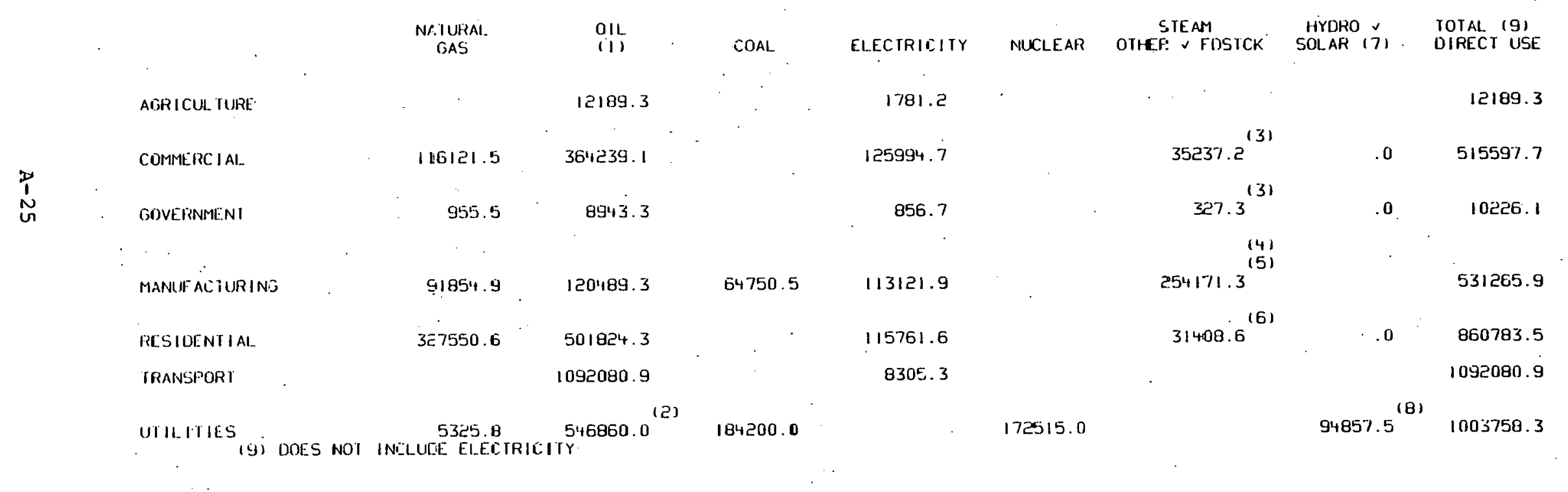


TABIE APPENDIX A

a

ENERTG DEMAND AND FUEL MIX

IEO9 BTU
SCENARIO- BASE CASE 4/79 YEAR-1976 RUN DATE-APR 06.1979 
NA IIIIKAL.

GAS

oll.

(1)

$20 \% 1$

EI.ECTRICITY

NUCLEAR

STEAT

OIHER V FDSTCK

HYDRO $\triangle$

SOLAR (7)

TOTAL 19

AGPICUL TURE

A.L CROF'S

A.LL STOCK

ELECTRICIIY

PROPANE

9435.0

1780.7

973.5

SECIOR TOTAL

12189.3

COMIMERCIAL.

AIR COND

APP-AUX COOUIP

I. IOHTING

SPACE HEAT

SECTOR IOIAI.

GOVERNMENI

AIR COND

APP-AUX EQUIP

AUTOS

I. IGHTING

SPACE HEAT

WATER HEAT

SECTOR TOIAL.

MANUFACTURING

ELEC DRIVE

FEEDSTOCK

PRIMARY ME TAAS

PROCESS HEAT
1020

17917.

36238.3
52682.7

$713 \% .1$
$431 \% .1$

116121.5

4044.9

125994.7

187.2

322.9

47.3
96.2

856.7

355.5

$89+3.3$

86785.5

$254171.3^{151}$

$\begin{array}{rrrr}21607.8 & 14891.3 & 795.3 & 26336.4 \\ 70247.0 & 105598.0 & 53955.2 & \end{array}$

35237.2

327.3
$91,35.0$

1780.7

973.5

12189.3

$352351.2^{(3)}$

.0

1020.2
.0

471403.4
113174

515597.7

$3273^{(3)}$

11.6

5579.6

4360.0

10226.1

. 


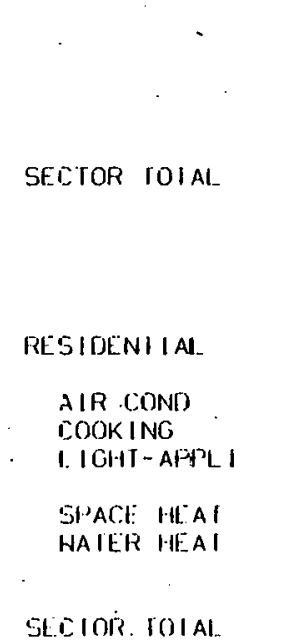

2
1
$N$
$\infty$

\section{TRANSPORI \\ FREIGAIT \\ PASS}

SECIOR IOIAI.

NAIUIIAI
I.jAS OHI $\quad$ COAL $\quad$ ELECTRICITY

918514.9

เสโมช89. 3

64750.5

113121.9

5.

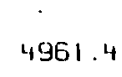

230672.9
$62+13.2$

436037.5

60825.4

327550.6

501824.3

z02984. 9

789096.0

1092080.9
10823.1

8152.2
80559.0

. 9495.0

6732.2

115761.6

162.5
8142.8

814.8

8305. 3
SIEAM
NUCLEAR OIMER $\checkmark$ FDSTCK SOLAR $17 \%$ TOTAL 191
DIRECT USE

254171.3

531265.9

302984.9 789096.0

1092080.9

$94857.5^{(8)} 1003758.3$

$94857.5 \quad 1003758.3$

\begin{tabular}{|c|c|c|c|c|c|c|}
\hline \multicolumn{5}{|l|}{ UTHITIES } & \multicolumn{2}{|c|}{ (8) } \\
\hline ELEC GENERAIION & 5325.8 & 546860.0 & 184200.0 & 172515.0 & 94857.5 & 1003758.3 \\
\hline SECTOR TOTAL & 5325.8 & $\Xi_{1} 6860.0$ & 184200.0 & 172515.0 & 94857.5 & 1003758.3 \\
\hline
\end{tabular}




. .

365821.4

$172515.0 \quad \operatorname{SEE}(3,4,5.6)$

SEE $(7,8)$

1025901.3

NOTES- $\because 1$ DISTILLATE ANIJ RESIDUAL COMBINEO. UNLESS NOTED

(2) RESIDUAL OIL TOTAL USE $=519493.0$

13) STEAM $\quad$ TDTAL USE $=35564.4$

(4) PETROCHEM TOTAL USE $=127581.7$

(5) COKING COAL - TOTAL USE $=426589.6$

$\begin{array}{llr}\text { (6) OTHER } & \text { TDTAL USE }= & 31+08.6 \\ \text { (7) SOL_AR. UNLEES NOTED } & \text { TOTAL USE }= & .0 \\ \text { (8) IISDRO } & \text { TDTAL USE }= & -91.357 .5\end{array}$

(9) DOES NOI INCLLDE ELECTRICITY 
TABLE 4

APPENDIX

FUEL DEMAND TABLES- 1 S85

IEOS BTU 
ACRICUL TURE

SCENARIO- BASE CASE DI/0I/79 YFAR- 1985

\section{SUBSECIOR GENERAL}

END-LISE ELECTFICITY

UNIT DEMANI 30.7I SATURATION 1.000

TECIS

TECHHOLOÓY

51.31 IE3 FABMS FUEL TECH TRAC EFF FUFL DEM

AGO TECH
SUESECTOR GENERAL

ND-USE PIOPAME

UNIT DEMANI

BASIS

TECH.HOLOGY

FUEL ${ }^{51}$

110.

SATURATI
IE 3 FARMS

PROPANE:
SUBSECTOR CROPS

END-USE ALL CROPS

$\begin{array}{lll}\text { UNIT DEMAND } & .37 \text { SATURR.TION } 1.000\end{array}$

BASIS

TECHNOLOG $4514.1 i^{3}$ IE 3 ACRES

1.000 GAS IECH OIL

4514.11

EFF FUEL DEM

SUBSECIOR LIVESTOCK

SUBSECIOR LIVESTOCK
END-USE

UND-USE ALL STOCK 17 SATURATION 1.000

BASIS

TECHNGLOG $1854.33^{17}$ SE 3 HEAT HEATION IECH FRAC 1.000 GAS TECH FUEL 1854.33
8351.1
.20

UEL DFM

.


COMMERCIAL.

SCINNARIO- GASE: CASE: DU/OI/79 YEAR- 1985

\begin{tabular}{|c|c|c|c|c|}
\hline $\begin{array}{l}\text { SUBSECTOR } \\
\text { END-USE }\end{array}$ & $\begin{array}{l}\text { HOSPIIIALS } \\
\text { AIR COND }\end{array}$ & & & \\
\hline $\begin{array}{l}\text { UNIT DEMANE } \\
\text { BASIS }\end{array}$ & $208.70^{14.00}$ & $\begin{array}{l}\text { SATURATION } \\
\text { IEG SO FI }\end{array}$ & 1.00 & \\
\hline TECIHNOLOGY & FUEL & TECH FRAC & EFF & FUEL DEM \\
\hline $\begin{array}{l}\text { AP COMP GAS } \\
\text { AP COMP EL." } \\
\text { OLAR }\end{array}$ & $\begin{array}{l}\text { GAS } \\
\text { ELECTRICITY } \\
\text { SOL_AR }\end{array}$ & $\begin{array}{r}7.51 \\
201.19 \\
.00\end{array}$ & $\begin{array}{l}1.80 \\
3.00 \\
1.00\end{array}$ & $\begin{array}{r}183.6 \\
2950.8 \\
.0\end{array}$ \\
\hline
\end{tabular}

\section{SUBSECTOR HOSPITALS}

$\begin{array}{lllll}\text { END-USE } & \text { APP-AUX EQUIP } & & \\ \text { UNIT DEMAND } & 40.00 & \text { SATURATION } & 1.000 \\ \text { RASIS } & 208.70 & \text { IEG SOFT } & & \\ \text { TECHNOLOGY } & \text { FUEI. } & \text { TECH FRAC } & \text { EFF } & \text { FUEL DEM } \\ \text { AGG TECH } & \text { ELECTRICITY } & 208.70 & 1.00 & 8348.0\end{array}$

$\begin{array}{lll}\text { TECHNOLOGY FUEI. } & \text { TECH FRAC EFF FUEL DEM } \\ \text { AGG TECH } & & \end{array}$

\section{SUBSECIOR HOSPITALS}

END-USE LIGHTINO

UNIT DEMAND 29.11 SATURATION $\mathbf{1 . 0 0 0}$ 208.70 IEE SOFT
FUEL

$$
\text { OIL }
$$



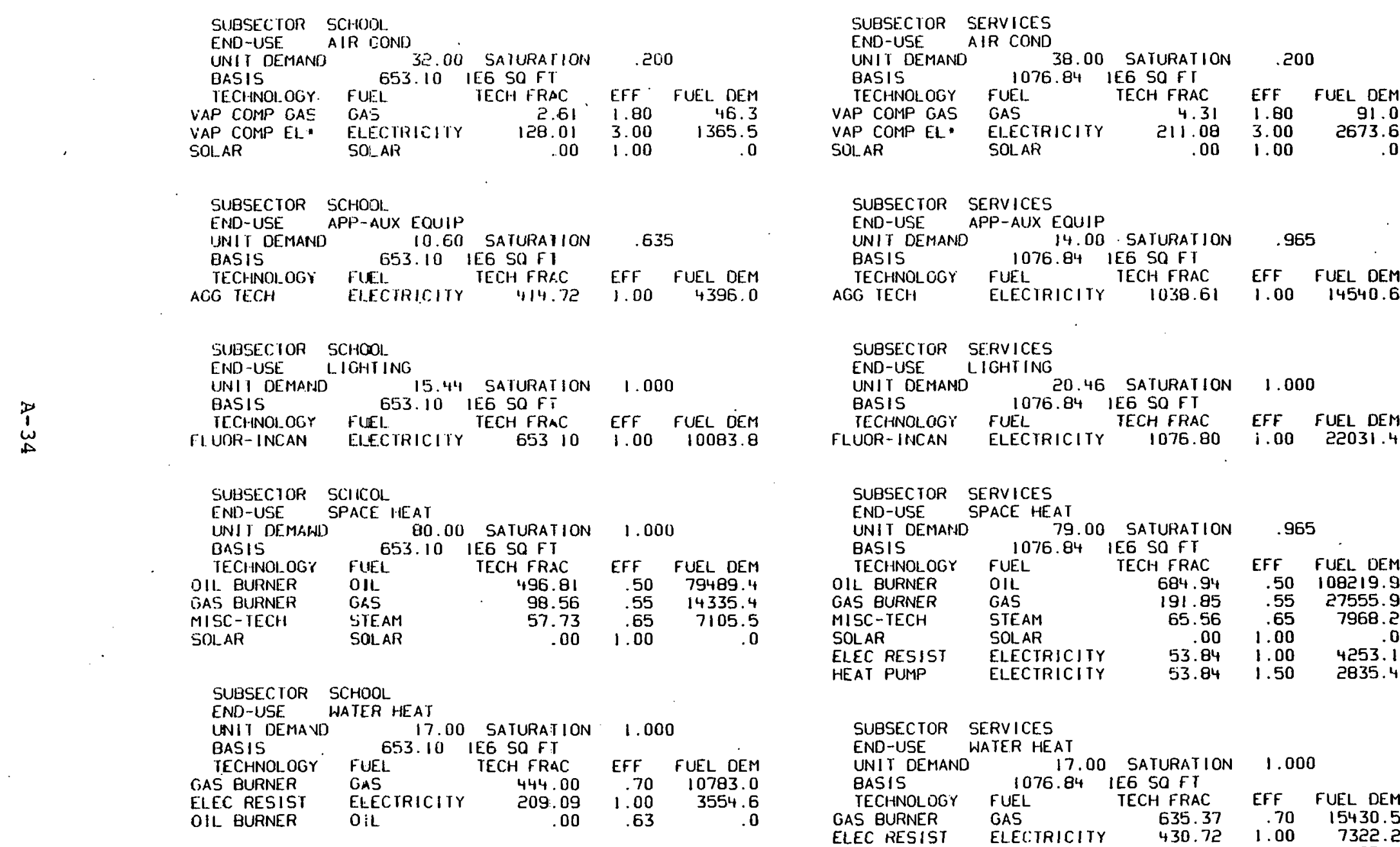

SUBSECTOR SERVICES

SUBSECTOR SERVICES

UNIT DEMAND 14.00 . SATURATION .965

UASIS 1076.84 IEG SOFT FA .965

TECHNOLOGY FUEL 1076.84 IEG SQF TECH FRAC EFF FUEL DEM

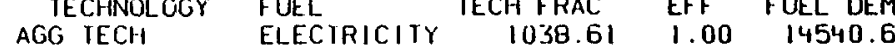

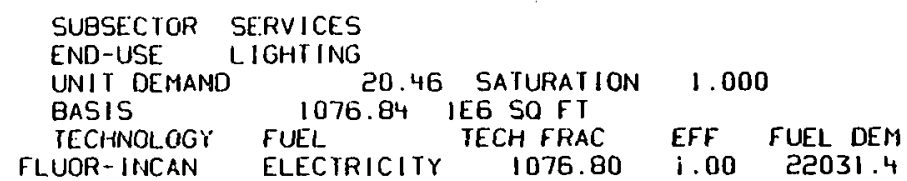


(iDVETKNIENI

SCENARIO- BASE CASE 04/01/79 YEAF- 1945

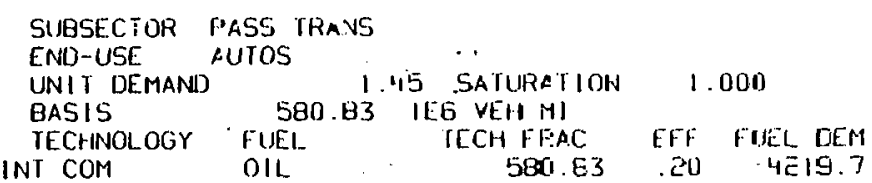

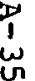

\begin{tabular}{|c|c|c|c|c|}
\hline $\begin{array}{l}\text { SUBSECIOR } \\
\text { END-USE. }\end{array}$ & $\begin{array}{l}\text { OFF ICES } \\
\text { AIR COHD }\end{array}$ & & & \\
\hline $\begin{array}{l}\text { UNIT DEMAND } \\
\text { BASIS }\end{array}$ & 35.00 & O SATURATIION & 1.00 & \\
\hline $\begin{array}{l}\text { BASIS } \\
\text { TECHNOLOGY }\end{array}$ & & $\begin{array}{l}\text { IEE SQ FI } \\
\text { IECH FRAC }\end{array}$ & $E F$ & FUEL DEM \\
\hline$P$ COMP GAS & & & 1.80 & 11.6 \\
\hline AP COIP EL. & ELECTRICITY & 16.25 & 3.00 & 189.6 \\
\hline
\end{tabular}

\section{SUBSECTOR OFFICES}

END-USE APP-AUK EQUIP

UNIT DEMAND I2.20 SATURATION 1.000

$\begin{array}{llll}\text { AGG TECH EI.ECTRICITY } 16.36 & 1.00 & 205.7\end{array}$

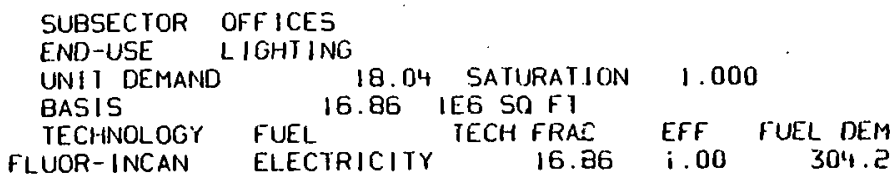




\begin{tabular}{|c|c|c|c|c|}
\hline $\begin{array}{l}\text { SUBSECTGR } \\
\text { ENIJ-USE }\end{array}$ & $\begin{array}{l}\text { SIC } 30 \\
\text { ELEC DRIVE }\end{array}$ & & & \\
\hline UNII DEMAND & 10.36 & S SATURATION & 1.00 & \\
\hline BASIS & $5+1.20$ & BMIL VAL ADD & & \\
\hline TECHNOLOGY & FUEL. & TECH FRAC & EFF & FIJEL DEM \\
\hline AC MOIOR & ELECTPICITY & 526.80 & 1.00 & 5457.6 \\
\hline $\begin{array}{l}\text { SUASECTOR } \\
\text { END-USE }\end{array}$ & $\begin{array}{l}\text { SIC } 30 \\
\text { PROCESS HIEAT }\end{array}$ & & & \\
\hline BASIS & 541.20 & SMII. VAL ADD & & \\
\hline TECHNNOLOSY & FUEL. & TECH FRAC & EFF & FUEL. DEM \\
\hline OAL BURNER & COAL & $8+.89$ & .70 & 918.0 \\
\hline AS GURNER & GAS & 307.70 & .6 & 3639.5 \\
\hline C. BUPNERR & OIL & 143.61 & .68 & 1651.4 \\
\hline
\end{tabular}

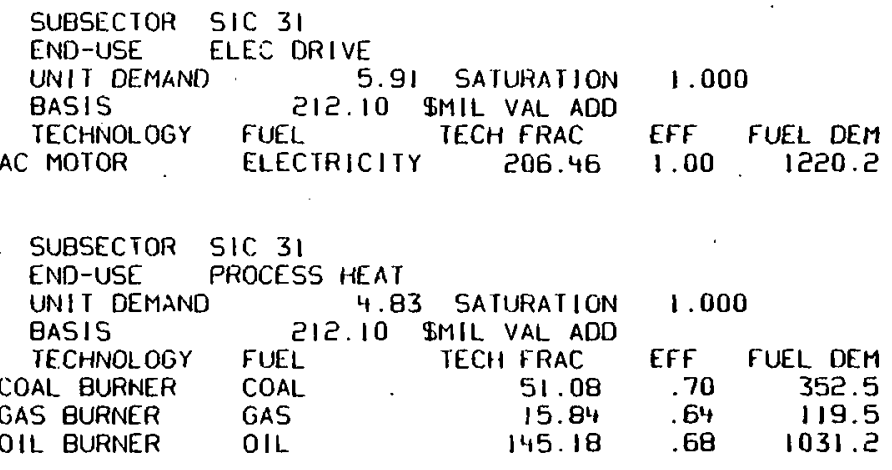

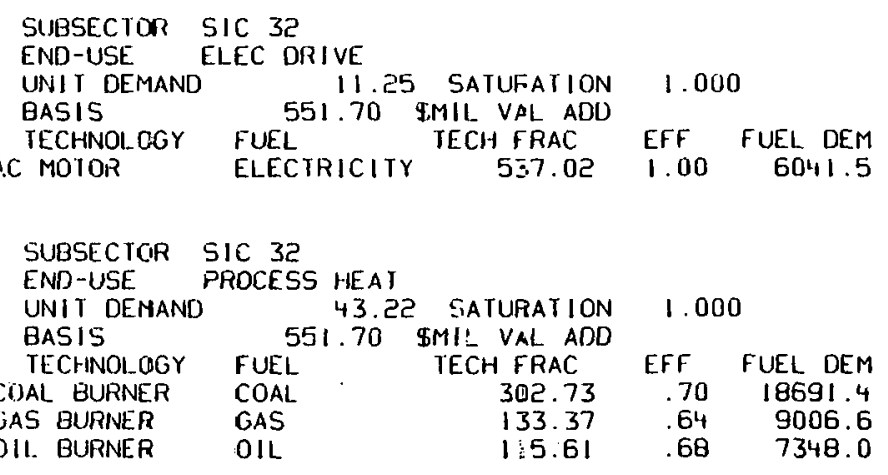

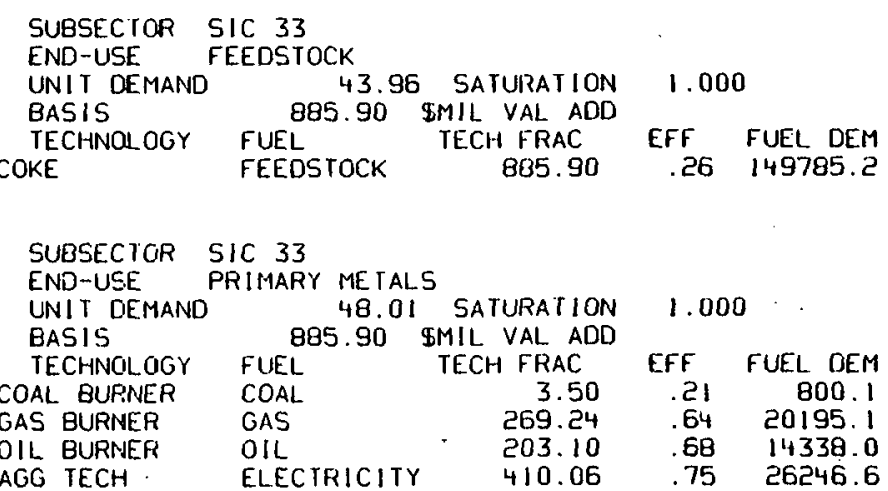




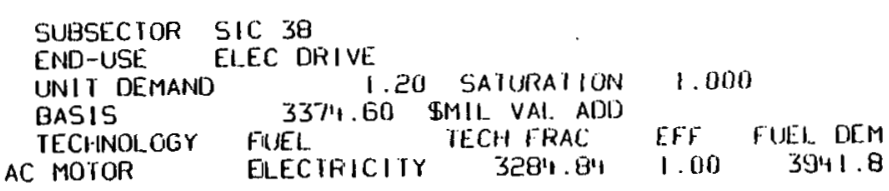

\begin{tabular}{|c|c|c|c|c|}
\hline $\begin{array}{l}\text { SUBSECTOR } \\
\text { END-USE }\end{array}$ & $\begin{array}{l}\text { SIC } 38 \\
\text { PROCESS HEAT }\end{array}$ & I SATURATION & 1.00 & \\
\hline $\begin{array}{l}\text { UNIT DEMAND } \\
\text { BAS IS }\end{array}$ & $337 \% .60$ & $\begin{array}{l}\text { SATURATION } \\
\text { SMIL. VAI. ADD }\end{array}$ & $1.0 \mathrm{C}>3$ & \\
\hline TECHNOL_OGY & FUEL & TECH FRAC & EFF & FUEL DEM \\
\hline BURNER & COAL & 1463.77 & .70 & 6260.4 \\
\hline GAS BURNER & GAS & $55+.28$ & .64 & ct \\
\hline OIL BURNER & OIL & 1353.56 & .68 & 1 \\
\hline
\end{tabular}

SUBSECIOR SIC 39

END-USE ELEC DRIVE

BASIS 981.20 SMIL VAL ADD

$\begin{array}{lrrrr}\text { TECHNOLOGY FUEL } & \text { TECH FRAC } & \text { EFF } & \text { FUEL DEM } \\ \text { MOTOR } & \text { ELECTRICITY } & 857.76 & 1.00 & 2539.0\end{array}$

AC MOTOR

SUBSECIOR SIC 39

PROCESS HEAT

UNIT DEMAND

ROCESS HEAT

BASIS

88

2.75 SATURATION 1.000

TECHNNOLOGY FUEL

COAL BURINER COAL

GAS BURNER GAS

SMIL VAL ADD

TECH FRAC

EFF FUEL DEM

$\begin{array}{rrr}360.07 & .70 & 1414.6 \\ 149.62 & 64 & 642.9\end{array}$

$\begin{array}{rrr}371.51 & .68 & 1502.4\end{array}$ 
FESICENIIAI.

SCENARIO- BASE CASE: OH, $11 \% \%$ TEAR- ISE5

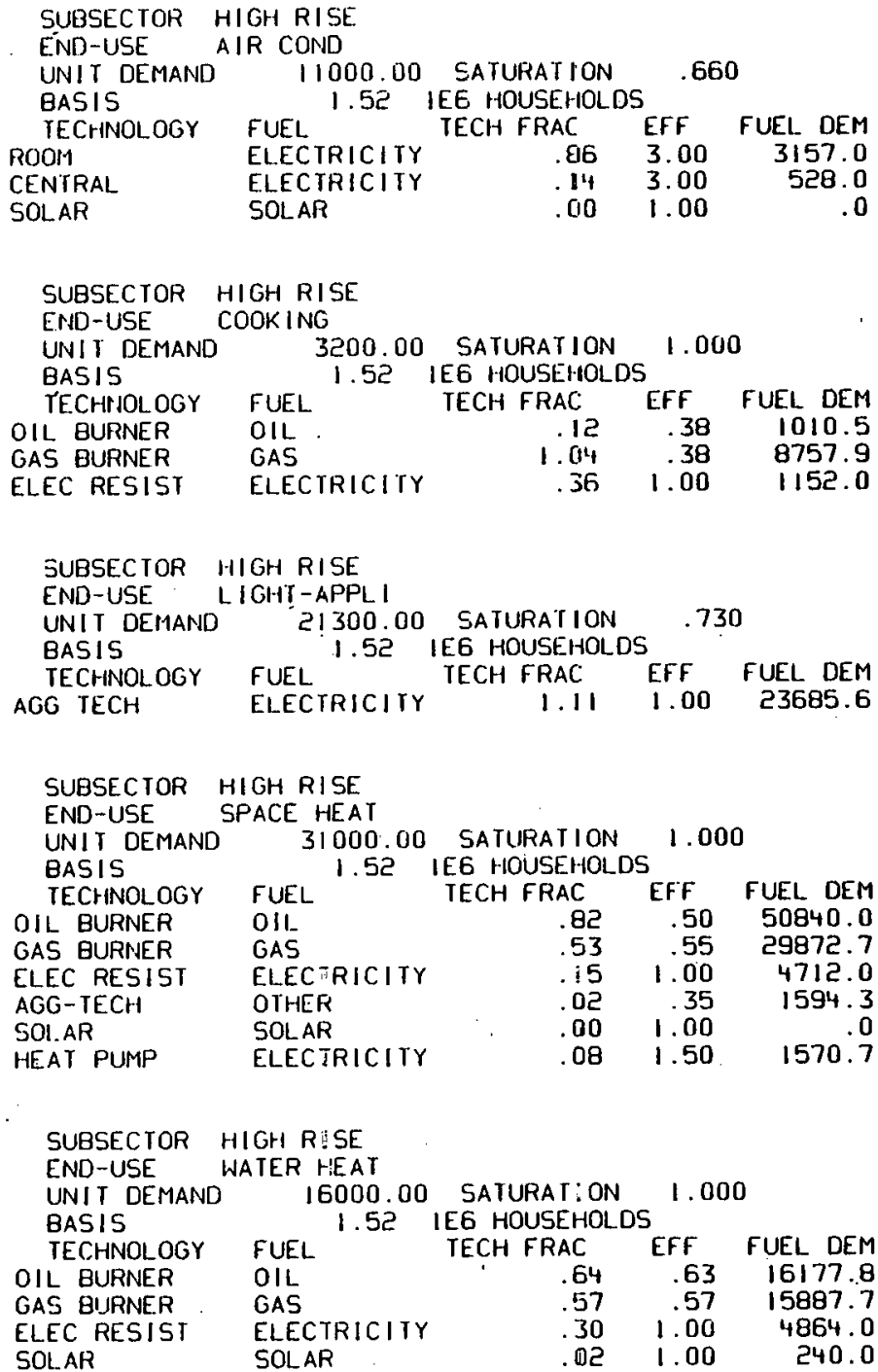




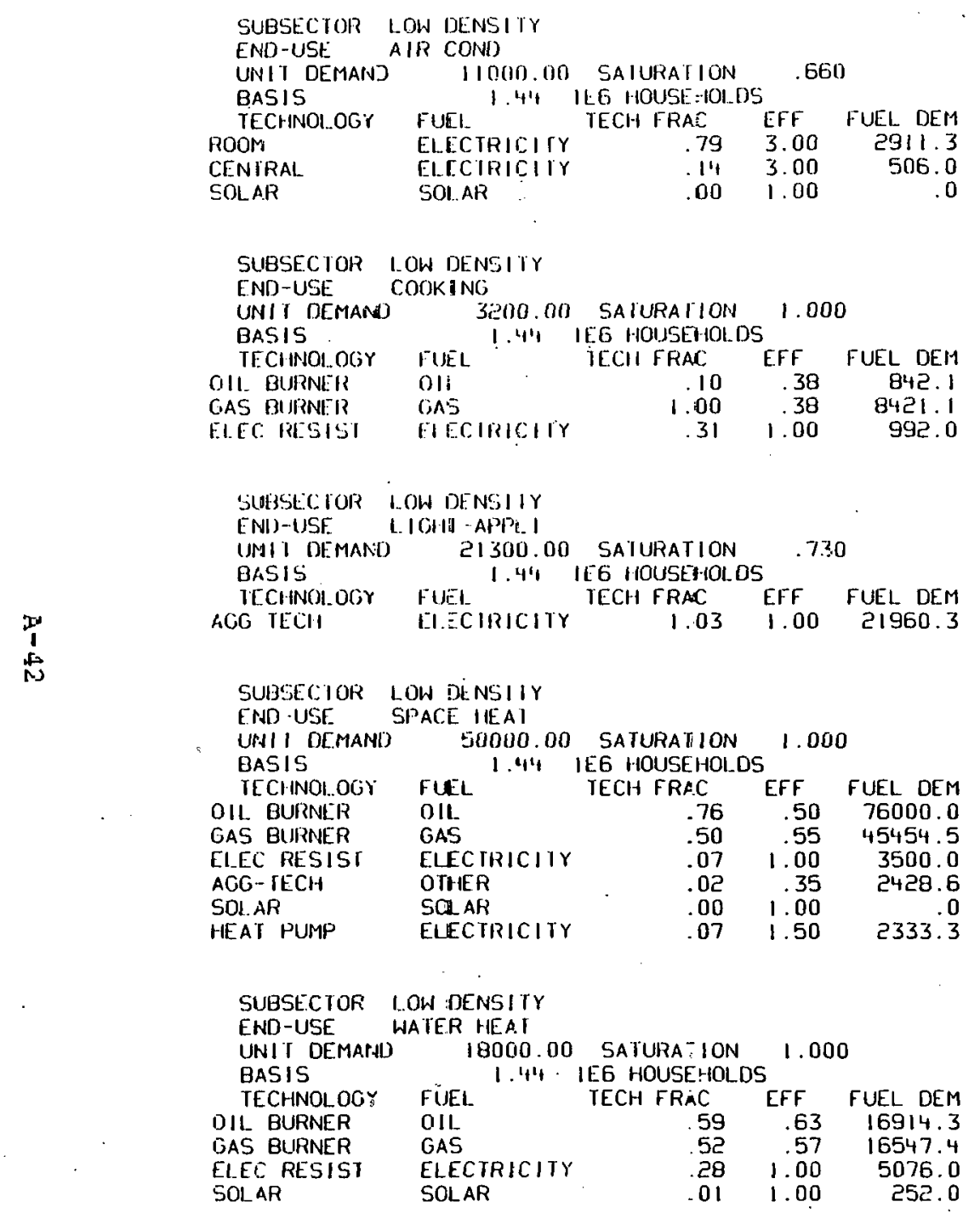

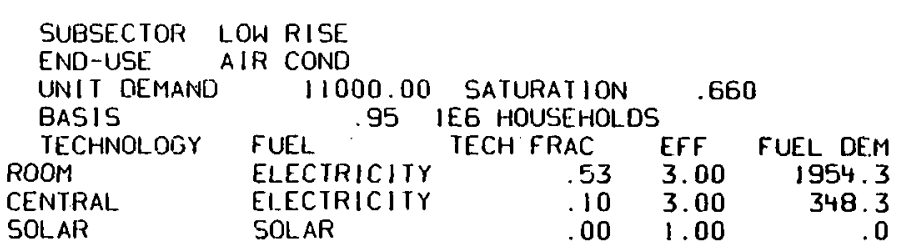

SUBSECTOR LOW RISE

END-USE COOKINO

UNIT DEMAND 3200.00 SATURATION 1.000

TECHNOLOGY FUEL TECH FRAC EFF FUEL DEM $\begin{array}{lllll}\text { OIL BURNER OIL } & .06 & .38 & 505.3\end{array}$

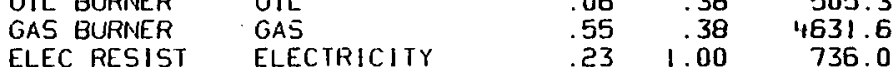

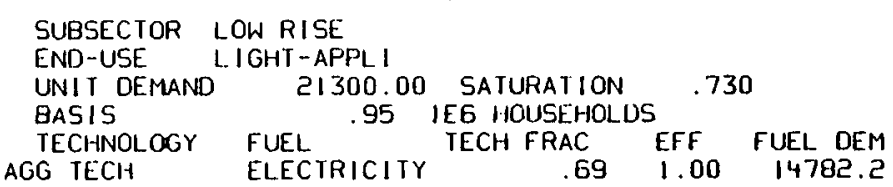


SUBSECTOR MOBILE HOMES

$\begin{array}{lc}\text { UNIT DEMANT } & 3200.00 \text { SATIJPATION } \\ \text { BASIS } & .32 \text { HUSEHLLOS }\end{array}$

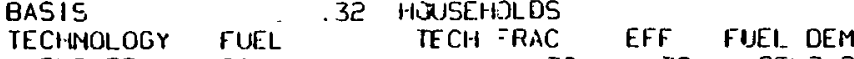

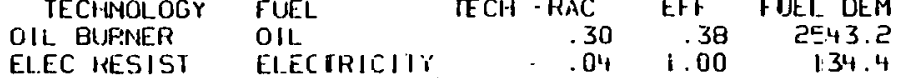

\section{SUBSECTOR MOBILE HOMES}

END-USE LIGHT-APPL I

UNII DEMANI E'I 300.00 SATURATION 1.000
BASIS

TECINIOLOGY FUE: . 2 HCUSEHELDS

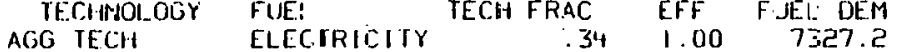

SUBSECTOR MOBILE hOMES

UNJT DEMAND 1 , J000.00 SATIRATION 1.000

BASIS .32 HOUSEHOL.OS H.

EFF FUEL. DEM

$\begin{array}{llllr}\text { OIL BURNER } & \text { OIL } & .31 & .50 & 24800.0 \\ \text { ELEC RESIST } & \text { ELECIRICITY } & .03 & 1.00 & 1360.0\end{array}$
END-USE COOKING

ENID-USE SPACE HEAT

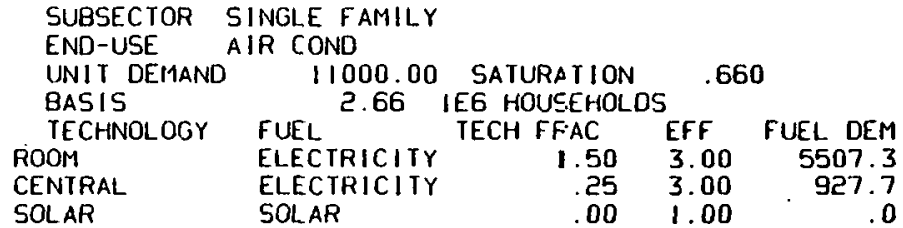

SOLAR

SOLAR

SUBSECIOR SINGLE FAMILY

END-USE COOKINO

UNIT DEMAND 3200.00 SATURATION. 1.000

BASIS 2.66 IEG HOUSEHOLOS

TECHNOLOGY FUEL 2. TECH FAAC EFF FUEL DEM

$\begin{array}{llll}\text { OIL BURNER OIL } & .18 & .38 & 1515.8\end{array}$

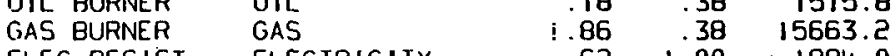

$\begin{array}{llll}\text { ELEC RESIST EI.ECTRICITY } & 62 & 1.00 & 1984.0\end{array}$

SUBSECTOR SINGLE FAMILY

END-USE LIGHT-APPL I

UN!IT DEMAND 21300.00 SATURATION .730

BASIS. 2.66 IEG HOUSEHOLOS

$\begin{array}{llccr}\text { TECHNOLOGY FUEL } & \text { TECH FRAC } & \text { EFF } & \text { FUEL DEM } \\ \text { AGG TECH } & \text { ELECTRICIIY } & 1.94 & 1.00 & 41343.3\end{array}$

SUBSECTOR MOBILE HOMES

END-USE WATER IEAT
UNIT DEMANO IIOOO.00 SAT.RATION .200

TECHOLOGY FUEL. 32 HECHFRAC EFF FUEL DEM

$\begin{array}{llll}\text { ELEC RESIST ELECTRICITY } & .07 & \mathbf{3} .00 & 253.0\end{array}$

$\begin{array}{llll}\text { OIL BURNEF OIL } & .07 & 3.00 & 253.0 \\ & .07 & .63 & 1564.8\end{array}$

$\begin{array}{lllll}\text { O1L. BURNEF } & \text { OIL } & .07 & .63 & 1564.8 \\ \text { ELEC RESISI } & \text { ELECTRICITY } & .28 & 1.00 & 4180.0\end{array}$
AGG TECH

\begin{tabular}{|c|c|c|c|c|}
\hline $\begin{array}{l}\text { SUBSECTOR } \\
\text { END-USE }\end{array}$ & \multicolumn{4}{|l|}{ LE $F$} \\
\hline UNIT DEMAND & 69000.00 & SATURATIO & 1.0 & \\
\hline BASIS & & IEG HOUSEHO & & \\
\hline TECHNOLOGY & FUEL & IECH FRAC & EFF & FUEL DEM \\
\hline IL BURNER & OIL & 1.42 & .5 & 195960.0 \\
\hline GAS BURNER & GAS & .95 & .55 & 119181.8 \\
\hline ELEC RESIST & ELECTRICITY & .13 & 1.00 & 8970.0 \\
\hline AGG-TECH & OTH & .03 & & 5914 \\
\hline 50 & SOLAR & .00 & 1.00 & \\
\hline IEAT F & ELECTRICIT & .13 & 1.50 & 5090 \\
\hline
\end{tabular}

SUBSECTOR SIMG_E FAMILY

END-USE WATER HEAT

UNIT DEMAND 25000.00 SATURATION 1.000

BASIS 2.66 IEG HOUSEHOLDS

TECHNOLOGY 'FUEL TECH FRAC EFF FUEL DEM

OIL BURNER OIL $\quad 1.11 \quad .6344047 .6$

GAS BURNER GAS $\quad 1.110 .63549047 .6$

$\begin{array}{lllll}\text { ELEC RESIST ELECIRICITY } & .99 & .57 & 43421.1 \\ & .53 & 1.00 & 13300.0\end{array}$ 
IRANSTIDIRI

SCENARIO- BASE: CASE 101/01/79 VEAR- 1985

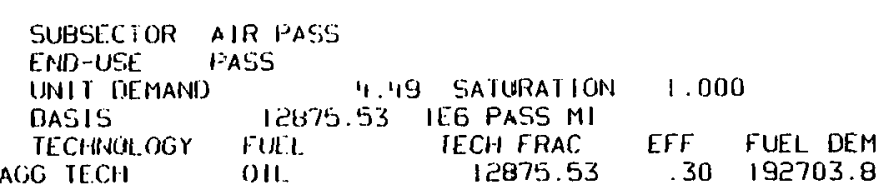

SJESECTOR BUS

ENO USE HAS:

2.67 SATURATION 1.000

519.82 ILO

UR:1. TECHFRAC EFF FUEL DEM

$\begin{array}{llll}\text { OII. } & 674.37 & .20 & 9002.8 \\ \text { Oll. } & 275.45 & .20 & 3677.3\end{array}$

\section{SUBSECTOR FALL FREIGHI}

END-USE FREIGIUT

UNIT DFMAND 23 SATURATION 1.000

BASIS

TECHINOIOOOY

$251999.3 i^{23}$ IEG TON MI

.000

DIESEI.

FUEL $\quad$ TECH FRAC EFF FUEL DEM

AGG TECH

$\begin{array}{lrrr}\text { OIL } & 21223.15 & .30 & 18328.9\end{array}$

AGO $1 E C H$

OIL

560.31

$.20 \quad 636.0$

$$
\begin{aligned}
& \text { SUBSECIOR HATER } \\
& \text { END-USE FREIGH } \\
& \text { UNII DEMAND .14 SATIJRATION } 1.000 \\
& \text { BASIS IOC710.00 IEE TONN MI } \\
& \text { TECHINIOGY FUEL TECH FRAC EFF FUEL DEM } \\
& \begin{array}{llrrr}
\text { OIESEL } & \text { OIL } & 12051.00 & .20 & 8194.7 \\
\text { AGG TECH } & \text { OIL } & 90589.00 & .20 & 61668.5
\end{array}
\end{aligned}
$$

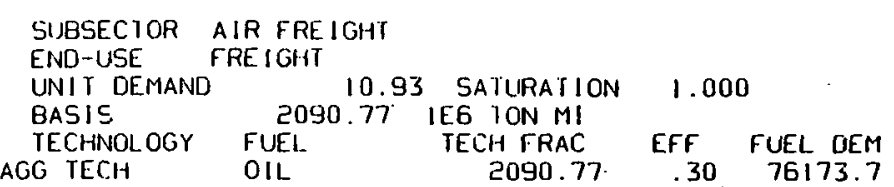

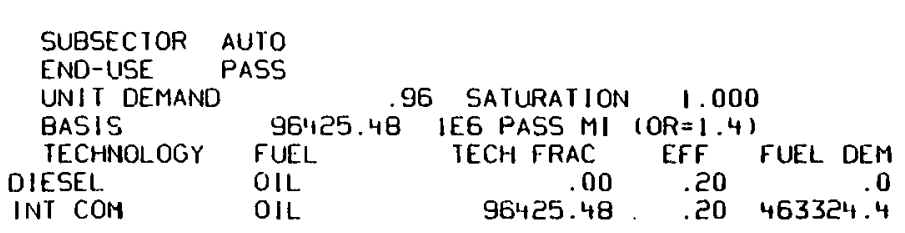

\section{SUBSECTOR RAIL \\ END-USE PASS}

UNIT DEMAND 1.00 SATURATION 1.000

BASIS 9466.83 IE6 PASS MI

TECHNOLOGY FUEL TECH FRAC

$\begin{array}{llr}\text { DIESEL } & \text { OIL } & 802.32 \\ \text { AGG TECH } & \text { ELECTRICITY } & 8664.58\end{array}$

$\begin{array}{rr}\text { EFF } & \text { FUEL DEM } \\ .30 & 2669.1\end{array}$

i. $.00 \quad 8647.3$

SUBSECTOR TRUCK

END-USE FREIGHT

UNIT DEMAND .95 SATURATION 1.000

BASIS 45389.82 IEG TON MI

TECHNOLOGY FUEL' TECH FRAC

$\begin{array}{lll}\text { DIESEL } & \text { OIL } & 26830.99 \\ \text { INT COM } & \text { OIL } & 18559.04\end{array}$

EFF FUEL DEM

.3377240 .7

$\begin{array}{ll}.33 & 77240.7 \\ .20 & 88155.4\end{array}$ 
IABLE 5

E.NERGY OOEMAND AND FUEL MIX SOEMARIO- BASE CASE 4/79 YEARRUN DATE-APR 06, 1979 


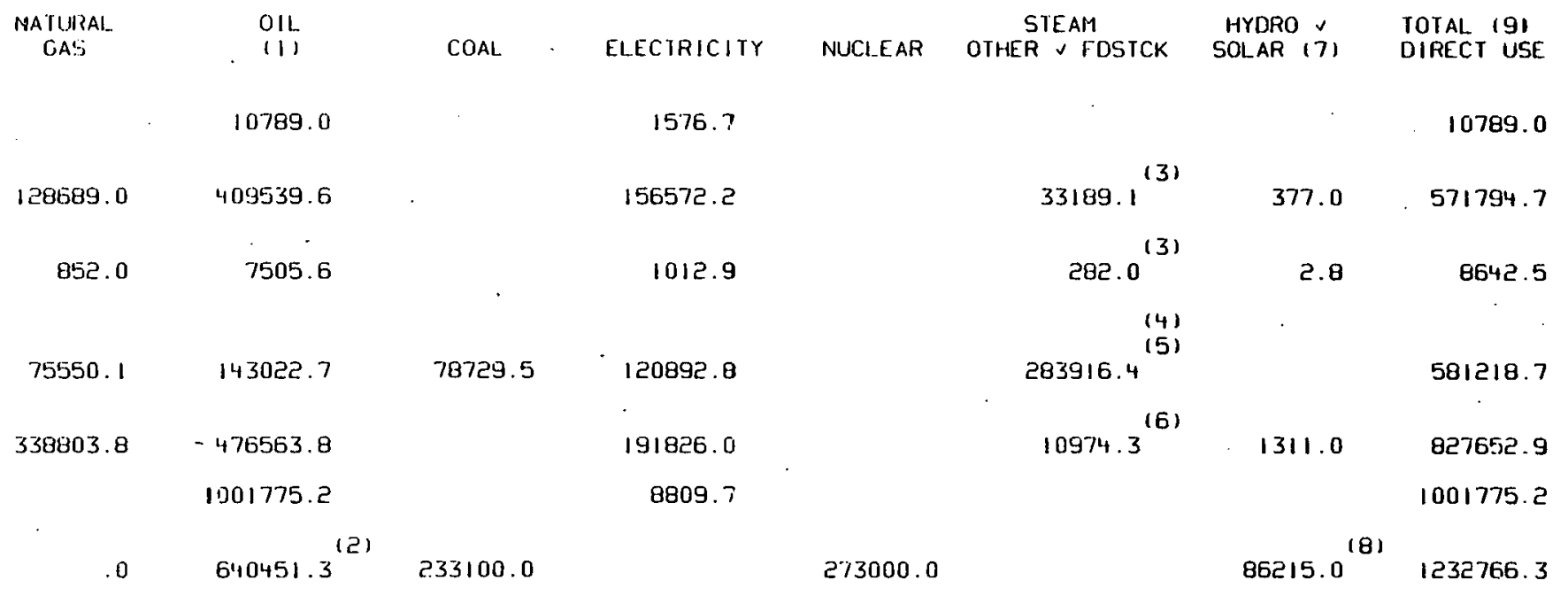


IABLE 6

APFENDIX $A$

感

ENERGY DEMAND AND FUEL MIX SCENARIO- BASE IEOS BTU RUN DATE-APR 06.1979 


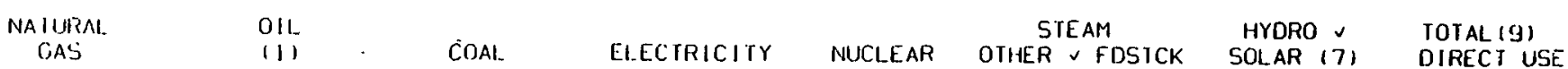

AGRICUL TURE

AL.L CROPS

ALL STOCK

PROPANE

SECTOR TOTAL

CCMMERCI AL

AIR CONO

APP-AUX EQUIP

LIGHTING

SPACE HEAT

WATEF HEAT

SECTOR TOTAL

3
1
0
0

\section{GO:JERNIIENT}

AIR COND
APP-AUX EQUIP
AUTOS

LIGHTING

SPACE HEAT

WATER HEAT

SECTOR TOTAL

MAMUF ACTURING

ELEC DRIVE

FEEOSTOCK

FRIMARY METALS FROCESS HEAT
0351.1
1576.2

1861.7

10789.0

1576.7

20341.9

41888.6
57245.0

82131.9
4.5105 .4

17526.7

19570.1

156572.2

$128689.0 \quad 409539.6$

189.6
205.7

304.2

198.8

114.6

1012.9

$852.0 \quad 7505.6$

(4)

283916.4
8351.1.

1576.2

861.7

10789.0

$33189 . i^{(3)}$

1151.7

0

33189.1

$377.0 \quad 571794.7$

$282.0^{13}$

282.0

$2.8 \quad 8642.5$
11.6
1219.7
.0

4166.9
244.2 
r.

SECTOR IOIAL

RES SIDENTI IAL.

AIR CONI)

COOKING

I. IGHT-APIIII

SPACE HEAT

WATER HEAT

SECIOR IOIAL.

点

\section{IR.TNSPORI \\ FRE IONII \\ PASS}

SECTOR TOIAL

UIII. IIIES

GENERATION

SECTOR TOTAL

\section{MA IURAI}

OII

Mbio. 1

143022.7

78729.5
ELECTRICITY

31176.0
30713.0

191826.0

338803.8

176563.8

330397.9

671377.3

1001775.2
120892.8

15810.0

4998.4

31176.0

STEAM
NUCLEAR OTHER $\checkmark$ FDSTCK

HYDRO
SOLAR (7)

28391ล."

162.5
8647.3

8809. 7
TOTAL 191

DIRECT USE

581218.7

330397.9 671377.3

1001775.2

$86215.0^{(8)} 1232766.3$

$86215.0 \quad 1232766.3$ 
GRAND TOIALS FOR SCENARIO BASE CASE 0!'79

YEAR- $\quad 1985$

\begin{tabular}{|c|c|c|}
\hline $\begin{array}{l}\text { NATURAL } \\
\text { GAS }\end{array}$ & $\begin{array}{l}\text { OIL } \\
111\end{array}$ & COAL \\
\hline \multicolumn{3}{|c|}{$\therefore$} \\
\hline $5+3895.0$ & $26896+7.3$ & 311829 \\
\hline ID RESIDUAL & COMBINED, UNL & ESS NOTED \\
\hline & TOIAL USE = & 627871.5 \\
\hline & ICTAL USE $=$ & 33471.1 \\
\hline & TOTAL USE = & 149785.2 \\
\hline & TOTAL USE = & 10974.3 \\
\hline NOTED & TOTAL USE = & 1690.8 \\
\hline & TOTAL USE = & 86215.0 \\
\hline
\end{tabular}

NOTES- - (1) DISTILLATE AND RESIDUAL COMBINED, UNLESS NOTED (2) RESUDUAL OIL TOTAL USE $=627871.5$

(3) STEAM TCTAL USE $=33471.1$

(ii) PETROCHEM TOIAL USE $=131131.2$

16. OTHER TOTAL USE = 10974.3

(7) SOL.AR, UNLESS NOTED TOTAL USE $=1690.8$

(9) DOES NOI - INCLUDE ELECTRICIIIY
RUN DATE- APR 06, 1979

$\begin{array}{cccccc}\text { ELECTRICITY NUCLEAR } & \begin{array}{c}\text { STEAM } \\ \text { OTHER } \checkmark \text { FDSTCK }\end{array} & \begin{array}{c}\text { HYDRO } \\ \text { SOLAR }\end{array} & \begin{array}{c}\text { TOTAL (9) } \\ \text { DIRECT USE }\end{array} \\ & 480690.3 & 273000.0 & \text { SEE }(3,4,5.6) & \text { SEE } 17.81 & 4234639.4\end{array}$




\section{APPENDIX B}

\section{COUNTY LEVEL DATA BASE}


"ALLCOUNT IES (COAL I\%

COUNTY

ALBANY

ALLEGGANY

BRONX

BROOME

CATTARAUGUS

CAYUGA

ChautauguUa

CHERTUINO

CHENANISO

CI. INTON

COLUMB.I A

CORTLAND

DEL_AWARE

DUTCHESS

ERIE

SSEX

FRANKI IN

GENESEE

GREENE

HAMIL TON

HERKIMER

JEFFERSON

KINGS

LEWIS

MADISON

MONRZOE

MONTGOMERY

NASSAU

NEW YOFKK

NI ADARA

ONE IDA

ONDNDAGA

ONTARIO

ORANGE

ORI_LANS

OSWEGO

OTHER

OTSEGO

PUTNAM

OUIJEENS

RENSSELAER

RICIMUND

ROCKI.AND

SARATOGA

SCIHENECTAIOY

SCHOHARIE.

SCIHUYI.ER
COAI. DEMAND ZOR NEH YORK STATE BY COUNTY
RES DEM RLS COSI
CI DEM
C I $\cos 1$
PA DEM
PA COST
TOTAL. AVE COST
\$1

275
7
7
25
18

0

0

0

0

79

0

25
185

0

81

9
0

0

383

0

227

227
0

$5+0$

0

0
0

0

32

35

.

0

in

0

520 
SEMECA

STE JBEN

ST. LALNRENCE

SUF $=O L K$

SUL_I I VAN

TIOJA

ULSTER

WARZEN

WAS IINOTON

WAY VE

WESTCHESTER

WYOMINO

YATES

TOTALS/AVERAGES

0
1
15
0
0
0
0
0
0
0
0
0
29
0
2.413


COUNTY

AL.BANY

AL.LEGANY

BRONX

BROOME

CATTARAUGUS

CAYUGA

CHAUTAUOUA

CHEMUNG

CHENANGO

CLINTON

COLUMBIA

CORTLANIT

DELAWARE

DUTCHESS

ERIE

ESSEX

FRANKL IN

FUU TON

GREENE

HAMILTON

HERK IMER

JEFFERSON

KINGS

LEWIS

L. IVINGSION

MALISON

MONROE

MONIGOMERY

NASSAU

NEW YORK

NIAGARA

ONE IDA

ONONDAGA

ONT ARIO

ORANGE

ORI.EANS

OSWEGO

OTSEGO

PUTNAM

QUEENS

RE:NSSEL AER

RiCHMMONO

ROCKLAND

SARA TOCAA

SCHENECTADY
SCHOHARIE

RES DEM RES COST

IN Witl?

G/KWHIR

CI DEM CI COST
MWHR

PA DEM
MWNHR

PA COST

\$ $/$ KWVIIR

TOIAL AVE COSI

57,948

\$. 03178

1. 722.421

$\$ .02344$

28.292

5. 06519

146,045

$1+2.186 \quad \$ .03146$

854.89 .3

$256.91+9$

\$. 08780

$\$ .03608$
$\$ .03158$

$\$ .03719$

385.727

204,376

$\$ .02602$

$\$ .03708$

9.03401

271,455

189.887

112.464

155.039

465,747

9.03246

$\$ .03579$

$\$ .03299$

$\$ .03200$

\$. $031+68$

123,010

148.268

126.527

152.275

14.148

210.237

226, 773

2. 065,045

64.500

128,151

$1,486,686$

126,784

$2.815,2811$
$1,224.360$

$490,51+8$

624.210

895.616

220.864
$1,95.814$

112.889

297,388

170.963

$\$ .03074$

\$. $029 E 9$

9.03408

$\$ .03313$

.04604

\$. 02799

\$. 03326

\$. 08780

Ф. 03408

\$. 03548

$\$ .03053$

$\$ .03492$

. 03408

.04969

\$. 08780

क. 03280

$\$ .03304$

\$. 03759

.05860

$\$ .0323$

\$. 03408

\$. 03824

2.065 .665

\$. (1) 86.34

$\$ .103150$

471,370

432,106

388.205

$321+.621$

\$. 108780

9.03145

9. 031408

$1,613.779$

$\$ .02064$

$\$ .07292$

$82.753 \$ .02292$

205.736 \$.02936

802,334

471.961

$110.613 \quad \$ .02610$

$315.730 \quad \$ .00778$

$223.252 \quad$ ⿷.02553

$184,917 \quad \$ .02362$

$124.900 \quad \$ .02927$

892.091 \$.03770

$5.028 .682 \quad \$ .02382$

$165.730 . \$ .02300$

196.688

$303.464 \quad \$ .02366$

$243.801 \quad 03785$

$19.739 \$ .02459$

$292.694 \$ .02216$

$\begin{array}{ll}2.569 .449 & \$ .02386 \\ 1.07292\end{array}$

$107.293 \quad \$ .02400$

197.499 \$.02557

136,238

$.794,886$

$3.186,684$

$9,278,729$

$3.857,101$

$.185,813$

2.4. 169

666,466

176,074

618.185

61.1859
81.885

80,085

2. 724.154

461,854
327.386

697,319

558,991

684,3415

2. 106

$\$ .02156$

$\$ .03107$

$\$ .02400$

$\$ .01,379$

$\$ .07292$

$\$ .02383$

\$. 02187

\$. 03150

$\$ .04730$

$\$ .02314$

\$. 02400

\$. 02919

$\$ .03061$

$\$ .07112$

9. 024 14

$\$ .05310$

$\$$

\$. 02148

$\$ .01769$

22. 086

$\$ .03270$

$\$ .05583$

212, 229

\$. 03085

44.610

13,516

61,975

16.182

8.405

8.405

32.806

37.598

206.751

12.263

6,164
3,225

4,043

3,725

8,558

4.127

937,087

1,158
28,586

14.686

376,545

4,122

258,0014

1.355 .753
13.333

27,185

48,102

50,210

16.958

2.63\%

9.690

38.102

19.598

943.598

11,997

12.846

$7.1 \mathrm{ets}$

12.761

'. 387

\$. 03233

\$. 01289

\$. 03184

\$. 03014

\$. 01756

$\$ .039414$

\$. 02934

D. 03165

$\$ .04351$

$\$ .02213$

\$. 02430

$\$ .06583$

$\$ .06282$

$\$ .03192$

\$. 02808

$\$ .04766$

$\$ .05583$

\$. 04216

\$. 03072

\$. $04288_{1}$

\$. 05585

\$.03791

$\$ .05583$

D. 04091

$\$ .05731$

$\$ .03715$

\$. 03684

$\$ .04575$

I. 06585

\$. 03204

$\$ .03183$

$\$ .0554$

\$. 05583

\$. 194789

$\$ .015085$

5. 06585

5. 01295

$2.325 .661 \quad \$ .02675$

$310.317 \quad 4.02616$

$3.080 .165 \$ .07366$

$1.353 .962 \$ .03153$

$751.088 \quad \$ .07608$

$415.579 \quad \$ .03309$

$1.231 .577 \quad \$ .01978$

$738.312 \quad \$ .031 \% 4$

266.515 \$.03049

$421.544 \$ 2.03043$

$304.187 \quad \$ .02751$

$312.745 \quad \$ .03063$

1.395 .436 \$.04080

$7.012 .045 \quad \$ .02715$

$301.003 \$ .02612$

356.4140 \$.02535

459:782 \$. 02724

$368,815 \quad \$ .04048$

34.669 \$.02889

$511.489 \$ 9.02465$ 


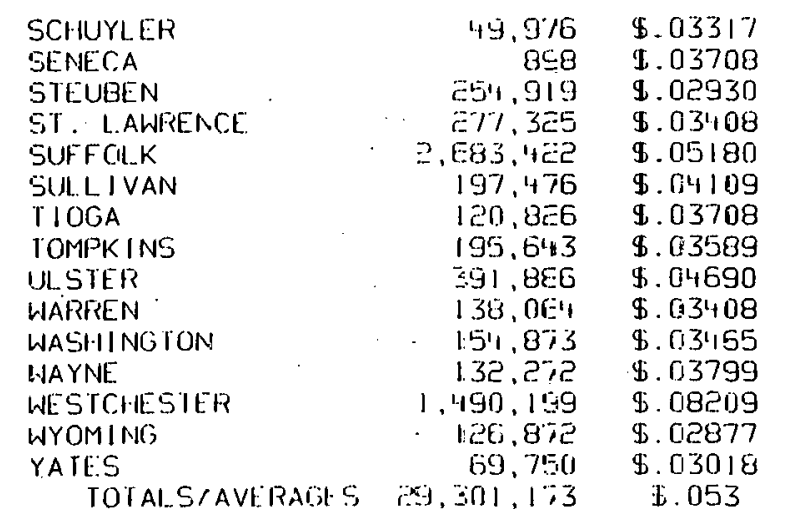

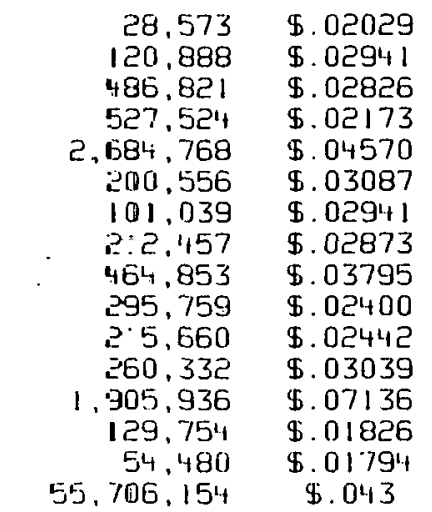

\begin{tabular}{|c|c|}
\hline $\begin{array}{r}3.909 \\
27.665 \\
47.716 \\
6.663 \\
313.155 \\
311.206 \\
12.314 \\
196.093 \\
11.311 \\
2.516 \\
5.493 \\
37.016 \\
356.747 \\
10.798 \\
95.435\end{array}$ & 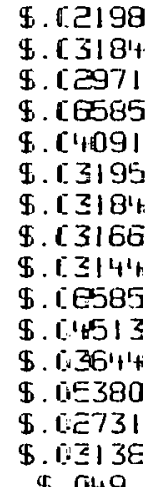 \\
\hline
\end{tabular}

82,158

$|1,1,15|$

$789.456 \quad 9.02391$

$811.512 \quad \$ .02631$

$5.681 .345 \quad \$ .01832$

$432.238 \quad \$ .03562$

$234.169 \$ .03350$

$604.193 \$ .03200$

868,050 क. 0419

436,369 \$. 12743

376.026 \$.0289'

$429.620 \quad \$ .03325$

$3.752 .882 \quad \$ .07395$

267.42119 .02361

$\begin{array}{ll}219.665 & \$ .02766 \\ 986.851 & \$ .047\end{array}$ 
COUNTY

ALBANY ALLEGANY

BRONX

BROOME

CATTARAUGUS

CAYUGA

CHAUTAUQUA

CHEMUNG

CHENANGO

COLUMEIA

CORTL AND

DELAWARE

DUTCHESS

ERIE

FULTON

GENESEE

GREENE

HERK IMER

w
RES DEM RES COST
MCF
\$/MFC

$$
\mathrm{MCF}
$$

$7.668 .539 \$ 2.33670$

1.459 .166 \$2.20813

$9.088,000 \quad \$ 4.26000$

$7.1,92.856 \$ 2.22500$

$3.485,723$ क2.21313

2.127.648 \$2.07900

8.183 .598 \$2.20800

$4.614 .254 \$ 2.06426$

379.897 \$2.07900

$660.515 \$ 2.33000$

$1.1+26.110 \$ 2.07900$

378.308 \$2.22500

$1.706 .595 \quad \$ 3.25000$

$59.631_{1} .424^{4} \quad \$ 2.20800$

1.484 .232 \$2. 33000

2,781:831 \$2.18642

$100.129 \$ 3.25000$

$1.281 .398 \$ 2.33000$

$2.132 .801 \quad \$ 2.33000$

$44.927 .376 \quad \$ 3.72000$

$1.428 .638 \$ 1.99783$

1.243 .871 कट.31ट10

$27.672 .724 \quad \$ 2.41581$

27.672 .724 \$2.44581

$\begin{array}{rr}1.629 .922 & \$ 2.33000 \\ 14.310 .373 & \$ 3.36000\end{array}$

$7.151 .000 \quad \$ 4.26000$

5.870 .059 \$2.17133

$8.102 .743 \$ 2.32843$

$17.736,724$ \$2 31551

ร. 178,510 \$5 11131

4. 571.360 52. 11131

.371 .366 \$2.6077

807.391 कर.10101

2.917 .868 \$2.33000

$183,233 \$ 2.07900$

$31.856 .930 \quad \$ 3.85015$

$3.300 .064 \quad \$ 2.33000$

$5.647 .846 \quad \$ 3.72000$

$10,658,647 \quad \$ 2.39000$

$3,676,678$ क2. 31927

11. 986.104 क 33000

297.983 \$2. 22500

$886.926 \$ 2.07900$

$3.271,086 \quad \$ 1.80673$

$1.541,198 \quad \$ 2.84000$

$12.365 .625 \$ 3.36000$

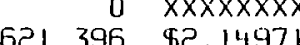

$\begin{array}{rr}621.396 & \$ 2.14971 \\ .989 .016 & \$ 2.07900\end{array}$
CI DEM CI COST
MCF

$4.615 .071 \$ 1.90252$

, 928,000 कर 90000

.679 .228

6.

1.432 .220 \$1.68353

1.432 .911 \$1.67400

$69.486 \$ 1.85700$

$5.289 .278 \quad \$ 1.67314$

$359,369 \$ 1.67400$

$1.384 .059 \$ 1.67400$

$309.052 \quad \$ 1.63500$

124.313 52 03000

$40,344,439 \quad \$ 1.85700$

$1.068 .421 \quad \$ 1.90000$

$2.473 .256 \$ 1.79276$

146,396 \$2. 03000

1.620 .987 \$1 90000

$10.520 .457 \$ 3.19000$

$721.405 \$ 1.65310$

$1.109 .991 \$ 1.89642$

$15.619 .982 \quad \$ 1.88922$

$1.070 .320 \$ 1.90000$

$8.725 .439 \$ 2.73000$

$12.183 .000 \$ 2.90000$

$10.086 .928 \quad \$ 1.81511$

$6.021 .978 \quad \$ 1.89782$

$15,006,873 \$ 1.84936$

$1.640 .267 \$ 1.68301$

$.120 .009 \$ 1.87653$

$2,030.503$ \$1.90000

$278,279 \$ 1.67400$

$10.571 .302 \$ 3.02272$

$1.878 .367 \$ 1.90000$

$939.938 \$ 3.19000$

$7.282 .014 \quad \$ 1.88000$

5.268. 808 का.83572

257.388 \$1. 63500

$865.484 \quad \$ 1.67400$

$5.028,108$ \$1.44225

$3.971 .183 \quad \$ 2.18000$

$6.001 .971 \$ 2.73000$

4.

2.080.724 \$1.671100

\section{PA DEM PACOST
MCF}

$13.165 \$ 1.99000$

$\begin{array}{rr}0 & X X X X X X X X \\ 1.367 .000 & \$ 2.17000\end{array}$

$x \times x \times x \times x x$

$\begin{array}{ll}0 & x \\ 0 & X X X X X X X X X \\ 0\end{array}$

$286.826 \$ 1.65300$

XXXXXXXX

$620.294 \$ 1.65139$

$33.842 \$ 1.65300$

$X X X X X X X X$

$370.549 \$ 1.65300$

$0 \quad X X X X X X X X$

$294.208 \quad \$ 1.99000$

$x \times x x x x x x$

$0 \quad x \times X X X X X X$

$30.181 \quad \$ 1.93000$

$39.634 \$ 1.99000$

$x \times x x x x x x$

$0 \quad x \times X X X X X X$

2.168 .892 \$2.73000

$56.509 \$ 1.70864$

183.620 \$1.65300

$1.670 .568 \$ 1.93000$

XXXXXXXX

$0 \quad x \times x \times x \times x x$

$1.023,000 \$ 2.17000$

$230.916 \quad \$ 1.65300$

$295 \$ 1.65300$

$29.862 \$ 1.65300$

372.649 क1 67198

171,759 क1.94953

$89.641 \$ 1.67293$ XXXXXXXX

$25.362 \quad \$ 1.65300$

$1.627 .099 \quad \$ 2.54208$

כ75.653 $\quad$ X $13 X X X X X$

$0 \times x \times x \times x \times x$

$7.99 \% \$ 1.65300$

$x \times x \times x \times x x$

$0 \quad x x X X X X X X$

$77.308 \quad \$ 1.65300$

$229.815 \quad \$ 1.44700$

$x \times x x x x x x$

$0 \quad x X X X X X X X$

$0 \quad X X \times X X X X X$

$59.302 \quad \$ 1.65300$

1.053 .929 \$1.65300
TOIAL AVE COSI

MCF S/MFC

$12.296 .775 \$ 2.17338$ $2.711 .712 \quad \$ 2.014378$ $16.383 .000 \$ 3.59351$

$11.172 .084 \quad \$ 2.03070$

10.408 .943 \$1 86090

3.847 .385 91.89640

8.253 .084 \$2.20504

$10.523 .826 \quad \$ 1.84335$

$773,108 \quad \$ 1.87209$

$1.314 .870 \$ 2.11601$

$3.180 .718 \quad \$ 1.85314$

$687.360 \quad \$ 1.95972$

$4.125,116 \quad \$ 2.53187$

$99,978.863$ 52.06636

2.552.653

5.285 .268 52.15002

286.159 \$2.45135

1.407 .847 \$2.29138

3.753 .788 \$2. $114+31$

$57.616 .725 \$ 3.58596$

2.206.55a \$1.8777

2.537 .482 \$2.08257

44.963 .274 92.23329

2.700. 4 2

23.035 .242 92.15056

20.357.018

20.357.000 \$3.34106

6.187 .903 \$1.94197

14.125 .016 \$2.11481

32.773 .459 \$2.10145

$4,191,126$ 91 90462

$6,863,134$ ga 36538

$1,359.333$ 91. 93030

4.948 .371 \$2. 15355

$786.8719,91.92201$

$44,055,331 \quad \$ 3.60330$

$5,178,431$ \$2. 17403

$6.860 .437 \quad \$ 3.60804$

$17,950,661$ \$2. 1831

$5.953 .463 \quad \$ 2.15697$

7.208709 क 1974

555.311 \$1

829.718 \$1.

8.532 .339 \$1.8694

5.515 .381 \$1.58221

18.367 .596 क2. 36479

4.747 9.1.154!1

$1.069 .243 \quad 91.97906$

5.123.669 \$1.83.690 


\begin{tabular}{|c|c|c|}
\hline UI_STER & 65.5. & $\$ 3.25000$ \\
\hline WARREN & 85.3 .833 & $9: 2.33000$ \\
\hline WASHINGTOH & 660,515 & $\$ 2.33000$ \\
\hline WAYNE & $2,131,6010$ & $\$ 2.25718$ \\
\hline WESTCHESTER & $15,583,000$ & $\$ 4.26000$ \\
\hline WYOMING & 1.514 .506 & $\$ 2 . .2242$ \\
\hline YATES & $454,9 \pm 9$ & 0806 \\
\hline VERAGES & $3 \div 9.976,0 \mathrm{~B}$ & 879 \\
\hline
\end{tabular}

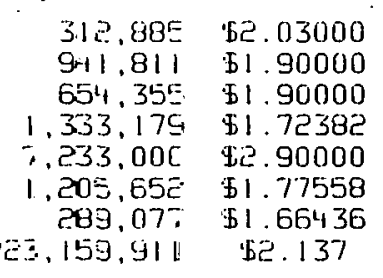

\begin{tabular}{|c|c|}
\hline 57,310 & $\$ 1.99000$ \\
\hline 0 & $X X X X=X X \cong$ \\
\hline 0 & $X X X X=X X X$ \\
\hline 325.628 & $\$ 1.75065$ \\
\hline $1,480,000$ & \$2. 17000 \\
\hline 1.091 & $\$ 1.65300$ \\
\hline 36,840 & \$1.65300 \\
\hline 307.884 & ĐE. $: 23$ \\
\hline
\end{tabular}

911.731 \$2. 75208 $1.795 .691^{1}$ \$? $.10^{1+147}$ $\begin{array}{ll}1.314 .870 & \$ 2.11601 \\ 3.793 .447 & \$ 2.00937\end{array}$ ग. 393.147 कट.00937 24.296 .000
2.721 .339
$\$ 1.72781$ $2.721 .339 \quad \$ 1.96857$

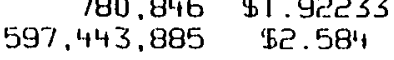


UILITY

BROOKL YN UNION CEN.TRAL HIJOSON COLIJMBIA CON. EO

COFiVING

L. II.CO

NATIONAL FUEL

NIAGARA MOHIALIK

NYSE+G

ORANGE +RDCKI AND

PAVILIILON

PENN + SOUTH

$\mathrm{RC}+\mathrm{E}$

ST. I. AWRENCE

SYFACUSE SUEUTRLAN

IOI AL SIAVERAGES

\begin{abstract}
RES DLM RES COSI
MCF
\end{abstract}
$7 \vec{c} .969 .589 \$ 3.720$ 3.636 .637 \$ 3.250 9.589.927 \$ 2.225 40.214 .000 क 4.260 c.096.266 \$ 1.538 $27.746 .561 \nsubseteq 3.360$ 80.887.216 \$2.208 $5 \%, 166,236$ \$ ट. 330 $19,422,150$ \$ 2.0.19 $13.799 .213 \quad \$ 2.390$ $1.681 .860 \% 1.3: 0$ 115.056 क 2.28 28.591 .703 क 2.450

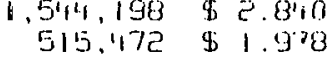

$9.976,040$ yir.8\%

CI DEM
$M C F$
6.320 .377
2.822 .842
0.746 .643
$30,396.000$
3.386 .939
$5.386,730$
4.596 .213
38.095 .216
$8.228,271$
9.108 .922
1.323 .436
102.395
5.754 .948
3.971 .183
2.919 .796

CI $C O S T$
$\$ /$ IIFC

$\$ 3.190$

$\$ 2.030$

$\$ 1.635$

$\$ 2.900$

$\$ 1.304$

$\$ 2.730$

$\$ 1.857$

$\$ 1.900$

$\$ 1.671$

\$1. 880

\$1. 603

$\$ 1.603$

$\$ 1.991$

$\$ 1.890$
$\$ 2.180$

$\$ 1.645$

2.23.159.911

$\$ 2: 137$

\begin{tabular}{|c|c|}
\hline $\begin{array}{l}\text { PA DEM } \\
\text { MCF }\end{array}$ & $\begin{array}{l}\text { PA COST } \\
\text { D/MFC }\end{array}$ \\
\hline & $\$ 2.730$ \\
\hline & \\
\hline 0 & $\times \times \times \times \times \times \times \times$ \\
\hline O & \\
\hline & \\
\hline 0 & $x \times x \times x \times x \times$ \\
\hline 0 & \\
\hline 0 & $\times \times X \times X X X X$ \\
\hline .720 .189 & $\$ 1.653$ \\
\hline 0 & $x \times x x$ \\
\hline 0 & $\lambda x x$ \\
\hline 0 & $x \times x x$ \\
\hline .877 & \\
\hline 0 & $x \times x$ \\
\hline () & $X \times X X X X X X$ \\
\hline 07 & $\uplus ट .1$ \\
\hline
\end{tabular}

$10 T \mathrm{AL}$
$\mathrm{MCF}$

$\underset{\text { D/MFE }}{\text { AVE }}$

92.812 .610

7.014 .959

$20,336,570$

$75,026,000$

5.717 .899

43.133 .291

$5,483,429$
$95,261.452$

$41,370,610$

$22,908,141$

3.005.296

217.451

46. 205.528

$5.515,381$
$3.1 .35,268$

$\$ 3.589$

\$2. 659

$\$ 1.913$

$\$ 3.586$

$\$ 1.396$

\$3. 135

$\$ 2.067$

\$2. 158

$\$ 1.862$

$\$ 2.187$

\$1 775

9. 115

\$2. 238

$\$ 2.365$

$597,443,8855$

$\$ 2.584$

"AL...UT II. IIIESIFLEECI\%

$01 . .11 Y$

CENTRAI IIIUOSON

CITY of JAMESIOHHA

CiTY OF PLATTSBINRGH

CON ED

LILCO

NIA.JARA MOIIALIK

NYSE+G

ORA. NGE +ROCKI ANI]

PASVY

RGS

VII SAGE OF TREEPORI

IOIAI s; AVERaGes
HEC DEHARID FOR NEW YORK STATE BY UTIL.TTY 1976

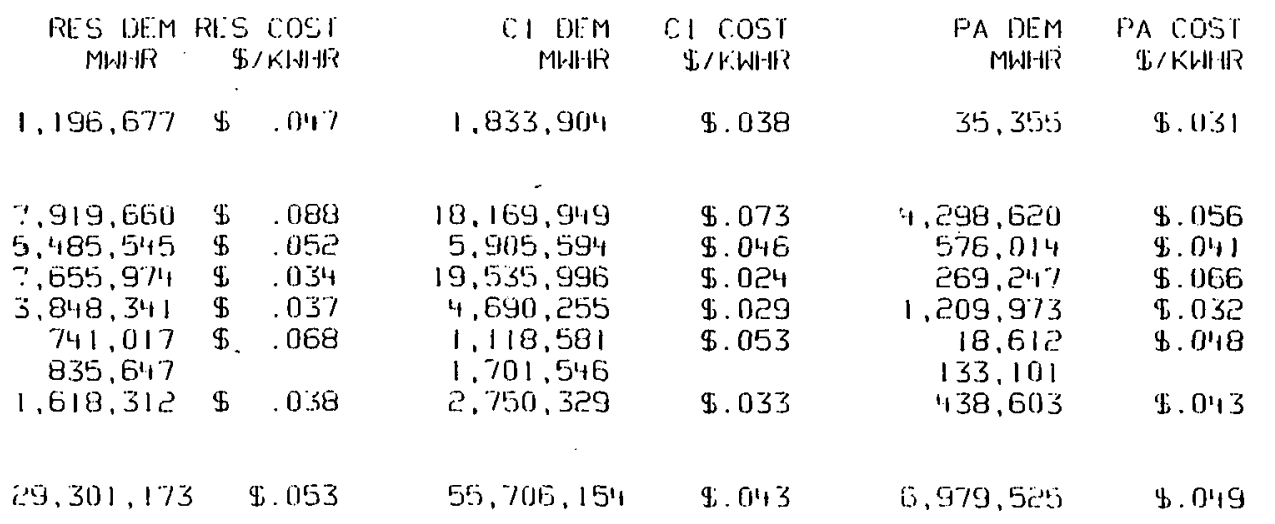

g. .
TOTAL

MWIIR AVE.

$3,065,936$

$30,388,239$

$11,967,153$

27, $461,2,16$

$9,748,569$

1.878 .210

$2.670,291$

1.807 .214

91.656 .728

i). 017 


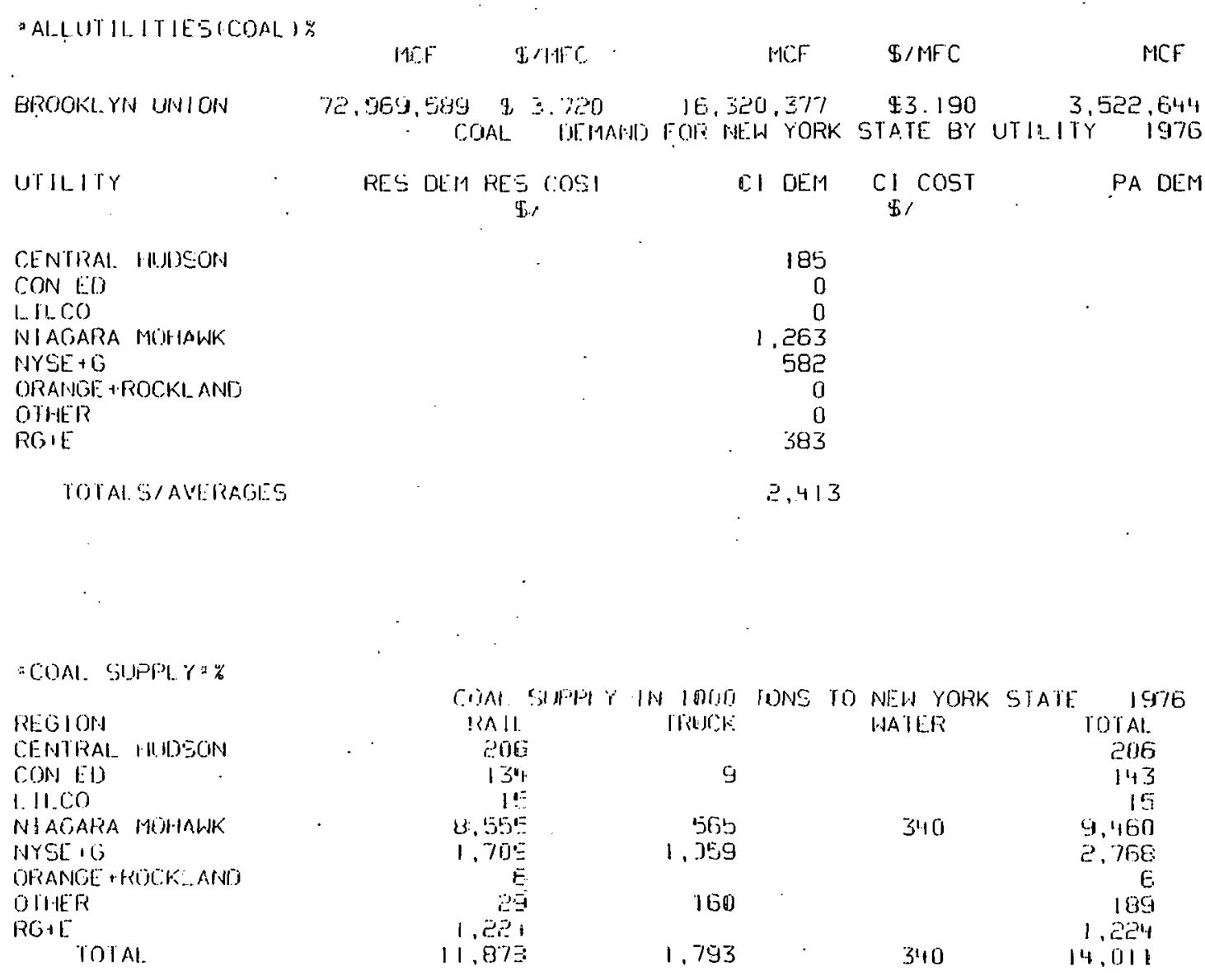


"COAL UTII ITY CENTRAL hIJIJSONN"\%

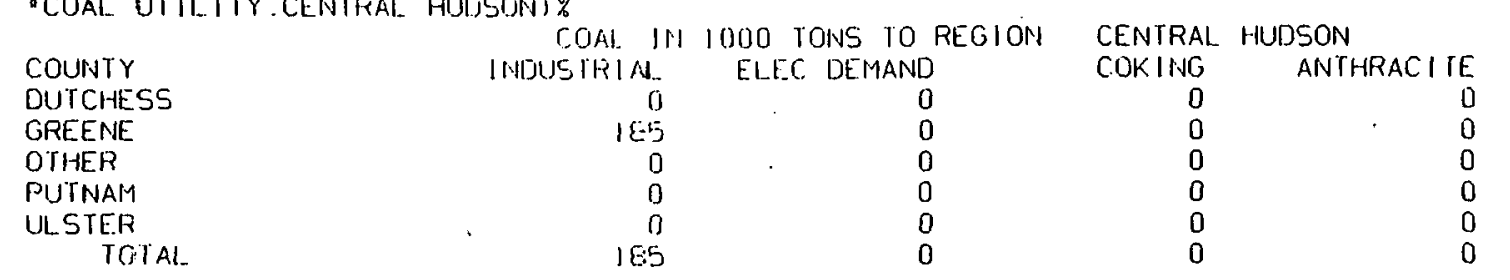

1976

$\begin{array}{rr}\text { OTHER } & \text { TOIAI } \\ 0 & 0 \\ 0 & 185 \\ 21 & 21 \\ 0 & 0 \\ 0 & 0 \\ 21 & 206\end{array}$

* COAL UTILITYICON EDI\%

COAL IN IOOO IONS IO REGION INUISSIRI AI. CI. IE DEMANID

BRONX

KINCS

NEW YORK

OTHER

OTEENS

RIEENS

WESICHESIER

TUTAL.

"COAL UIII. ITY $(1.11 .00)$

COUNTY

NASSAU

OTHER

SUFFOI.K

$10 \mathrm{IAI}^{-1}$
COAL IN IOOO TONS TO RE.GIOH INOUSTRIA

FLEC DEMAND
0
0
0
0

0
0
0
0
0
0
0
0

0
0
0
0

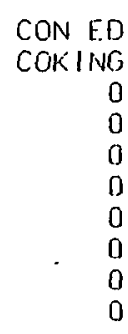

ANTHRACITE

ANTHRACITE

0
0
1

111

0
0
0

141

L. II_CO

COKING

0
0
0
0

ANTHRACITE
0
15
0
15

1976

ortit:

IOIAl

$0 \mathrm{Al}$
2
0
0
111
0
0
0
0
113

0
0
0
0

11
0
0
0
13

1
0
21
0
0
0
0

0
5
0
5 
"COAL UTILITY(NIAGRzA MOHALHK)\%

\begin{tabular}{|c|}
\hline COUNTY \\
\hline ALBANY \\
\hline $\begin{array}{l}\text { CATTARAUGUS } \\
\text { CHAUTAUGUA }\end{array}$ \\
\hline $\begin{array}{l}\text { CHAUTAUGUA } \\
\text { CLINTON }\end{array}$ \\
\hline COL.UMBIA \\
\hline CORTLANII \\
\hline ERIE \\
\hline $\begin{array}{l}\text { ESSEX } \\
\text { FRANKI.IN }\end{array}$ \\
\hline $\begin{array}{l}\text { FRANKI. IN } \\
\text { GENESEE }\end{array}$ \\
\hline $\begin{array}{l}\text { GENESEE } \\
\text { HAMILTON }\end{array}$ \\
\hline HERK IIIER \\
\hline JEFFERSON \\
\hline LENIS \\
\hline MONTGOMERY \\
\hline NIAGARA \\
\hline ONE IIJA \\
\hline OIVONDAGA \\
\hline ORLEEANS \\
\hline OSWE: 00 \\
\hline RENSSEI AEK \\
\hline SARATOOA \\
\hline SCHENECTADY \\
\hline SCHOHARIE \\
\hline ST I ALVRENCE \\
\hline WARREN \\
\hline $\begin{array}{l}\text { WASHINGIDR. } \\
\text { IOIAL. }\end{array}$ \\
\hline
\end{tabular}

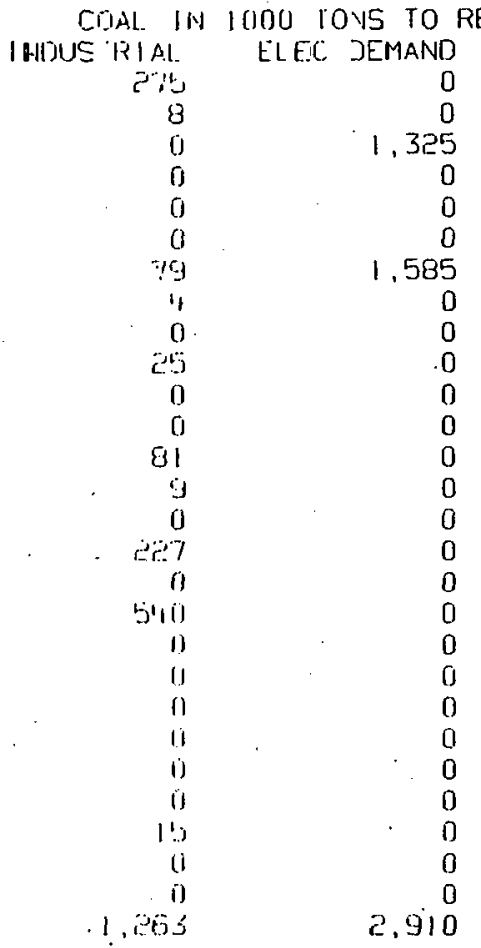

\begin{tabular}{|c|c|}
\hline $\begin{array}{l}\text { NIAGARA } \\
\text { COKING }\end{array}$ & $\begin{array}{l}\text { MOHHAINK } \\
\text { ANTHRACITE }\end{array}$ \\
\hline 0 &.$\quad 0$ \\
\hline 0 & 0 \\
\hline 0 & 0 \\
\hline 0 & 0 \\
\hline 0 & 0 \\
\hline 0 & 0 \\
\hline 5.157 & 0 \\
\hline 0 & 0 \\
\hline 0 & 0 \\
\hline 0 & 0 \\
\hline 0 & 0 \\
\hline 0 & 0 \\
\hline 0 & 0 \\
\hline 0 & 0 \\
\hline 0 & 0 \\
\hline 0 & 0 \\
\hline 0 & 0 \\
\hline () & 117 \\
\hline 0 & 0 \\
\hline 0 & 0 \\
\hline 0 & 0 \\
\hline 0 & 0 \\
\hline 0 & 0 \\
\hline 0 & 0 \\
\hline 0 & 12 \\
\hline 0 & 0 \\
\hline 0 & 0 \\
\hline 5.157 & 129 \\
\hline
\end{tabular}

1976

IOIAL

275
8
1,325
0
0
0
6,821
4
0
25
0
0
31
9
0
227
0
657
0
0
0
11
0
0
29
0
0
9.159


"COAL UTILITYINYSE+GI"

COUNIY
ALLEGANY
BROOME
CAYUGA
CHEMUNG
CHENANGO
DELAHARE
LIVINGSTON
MADISON
OTHER
OTSEGO
SCHUYLER
SENECA
STEUBEN
SULLIVAN
TIOGA
TOMPKINS
WYOMING
YATES
TOTAL

COAL IN 1000 TONS TO REGION IHOUSTRIAL ELEE DEMANO

NYSE $+G$
COKING
0
0
0
0
0
0
0
0
0
0
0
0
0
0
0
0
0
0
0

$\begin{array}{rr} & 1976 \\ \text { ANTHRACITE } & \\ 0 & \\ 70 \\ 0 \\ 0 \\ 0 \\ 0 \\ 0 \\ 0 \\ 0 \\ 0 \\ 0 \\ 0 \\ 0 \\ 0 \\ 0 \\ 0 \\ 0 \\ 0 \\ 70\end{array}$

$\begin{array}{rr}\text { OTHER } & \text { IOIAL } \\ 0 & 0 \\ 0 & 120 \\ 0 & 0 \\ 0 & 0 \\ 0 & 1911 \\ 0 & 0 \\ 0 & 0 \\ 0 & 0 \\ 0 & 0 \\ 0 & 32 \\ 0 & 520 \\ 0 & 0 \\ 0 & 1110 \\ 0 & 0 \\ 0 & 0 \\ 25 & 777 \\ 0 & 29 \\ 0 & 386 \\ 25 & 2.768\end{array}$

$\stackrel{\text { 苫 }}{⺊}$

$\begin{array}{rr}A . & \text { ELEE DEMANO } \\ 0 & 0 \\ 0 & 350 \\ 0 & 0 \\ 0 & 0 \\ 0 & 194 \\ 0 & 0 \\ 0 & 0 \\ 0 & 0 \\ 0 & 0 \\ 32 & 0 \\ 50 & 0 \\ 0 & 0 \\ 0 & 409 \\ 1 & 0 \\ 0 & 0 \\ 0 & 752 \\ 0 & 0 \\ 29 & 386 \\ 0 & 2.091\end{array}$

"COAI . UTIL ITY(CURANGE +ROCKI_AND):\% COUA:
COUNTY INDUSTIYIAI

$\begin{array}{ccc}\text { II. IOOO IONS IO REOION } \\ \text { AI. } \\ 0 & \text { ELEC DEMANO } \\ 0 & & 0 \\ 0 & & 0 \\ 0 & & 0 \\ & & 0\end{array}$

ORANGE +ROCKI ANND

COKING

$\begin{array}{rr}\text { NO } & \text { ANIHARACIIE } \\ 0 & 0 \\ 0 & 0 \\ 3 & 0 \\ 0 & 0\end{array}$

1976

ORANGE

OTHER

rOTAL

ACUAL UIII. ITY OOHHRI:\%

COUNTY

OTHER

IOIAI.
COAL IN 1000 TONS IO REGION IMIJUSIRIAI

ELEC OEMANO

0
OTHER

COKINO

0
0

ANTHRACI 115
189
189
$19 \%$

OIIIIR

0 
"COAL UTILITYYRO+E:\%

COUNTY
MONROE
ONTARIO

ONTARIO

WAYNE TOTAL
COAL IN IUOO TONS TO REGION MDUSTRIA

ELE:- DEMAND

$r 80$
$\quad 90$
0
780

$? 80$

\section{$R G+E$}

COKING

0
0
0

"COUNIIES IN REGIORICGAS, L. HICOS: COUNTY NAME

" "NASSAL "

- OUEENE

00
1
$N$

: SUFFOLK

*COUNI IES IN REGIOIAEIEC, I II.C., COUNTY NAME

$\because *$ *

- NASSAlI

- DUEENS

* SIJFFOL.K

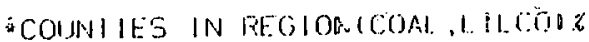

COLNTI INAME

$\because 4: A$

" NASSAu

- SUFFOl. $k$

* OTHER 
*COUNTIES WITHGIJI COAL LEI.IVERT:\%

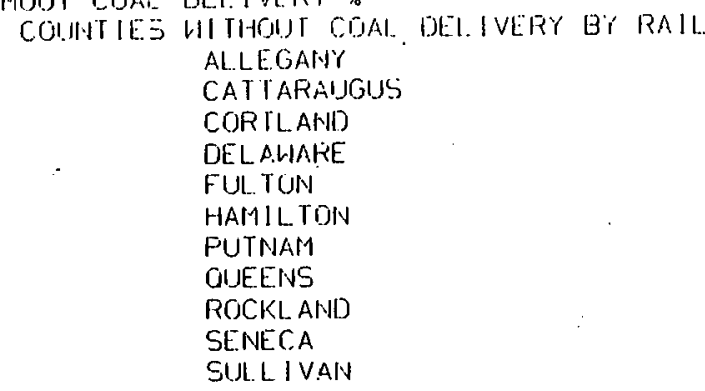

"COUMT URII POI ISUFH ONKL

\begin{tabular}{|c|c|}
\hline POLER PI ANI & UTH $11 Y$ \\
\hline E. HAMPION & 1. $\mathrm{HLCO}_{-}$ \\
\hline HOL BROOKK & 1. $11 . \mathrm{CO}$ \\
\hline MONT AUJK: & L. ILCO \\
\hline NORIIPORT & L II...CO \\
\hline POHI JEFFERSON & LILCO \\
\hline SHOFE:HAM & L IILCO \\
\hline SOUTH HOLL & $1.11 \mathrm{CO}$ \\
\hline 5: HAMPION & L.ILCO \\
\hline W. BABYI.ON & 111.60 \\
\hline
\end{tabular}

PIBLUTION IN IONS FOR ALIJE'TMOES $-\ldots . . . . .-2$ $1 \bar{c} .5$ 2.13.8 910.6

.

.1

321.0
SUFFOLK

$\begin{array}{ll} & \\ \text { SUFFOLK MARBON MONO HYORO } & 1976\end{array}$

37.5
641.5
283.7
.1
.3

963.1
HYRO CARBON NITROGEN OXIDE

$$
25.0
$$

$1,27: 7$

189.1
.0

.2

642.0

(1)

1312.0
221153.5
9929.1
2.2
8.8

$33 \% 105.6$
PARTICULATES SULFUR $010 \times 10 E$ PARTICULATES SIM.FUR GIOXIBE

100.0

$39 \% .3$

1710.7

756.5

หรล.

$34,31 \cdot 3$

2.4

2568.1
$11 \%$

"COUNIY IGAS, SIJFFOLKI: GAS DEMANJ FOR COUNIY SINFOLK
UTILIIV
RES DEM RES COST
MCF
$\begin{array}{ll}C I \text { DEM } & \mathrm{CI} \text { COST } \\ \text { MCF } & \text { MMH C }\end{array}$
1.1100
$\therefore .365,625 \quad \$ 3.36000$
$6.001 .9 \% 1 \quad \$ 2.73000$
IOIMISIAVERACES
: $2.365,625 \quad \$ 3.36000$
$6.001 .9 \%$
$\$ 2.73000$

PA DEM PACOSI
IICF
0
0

0

\begin{tabular}{|c|c|}
\hline $\begin{array}{l}\text { TOTAI } \\
\text { MCF }\end{array}$ & $\begin{array}{c}A V I \\
\Phi / M^{-C} \text {. }\end{array}$ \\
\hline $18,367,596$ & 93.1514 \\
\hline $18.36 \%, 596$ & 43.15 \\
\hline
\end{tabular}


"COUNTY IEI.EC, SIJFH OLK: \%

PUIMAl'

ELET DLMATIO FOR COUNTY SUFFOLK

UTHLY ITY

RES DFM FISS COSI

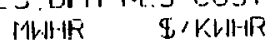

CI DEM CI COST
I.WHAR

2. 677.839 \$. 05191

5,533

己. 678,067

6.701

L.ILCO
PASNY

TOTALS: AVERAGES

2. $683,428 \quad \notin .05180$

$\bar{\varepsilon} .634 .766$

$\$ .0458$

\$. $0{ }^{1}+570$

CONL DHFAIND + OF COUNIY SUFFOLK

* COUNITYICOAL. SUJFOLK:\%

its lam kas com

CI DEH

C. $\sin \cos$

UIIITY

I. I1.CO

(1)

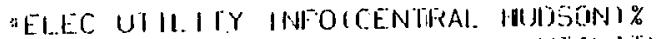

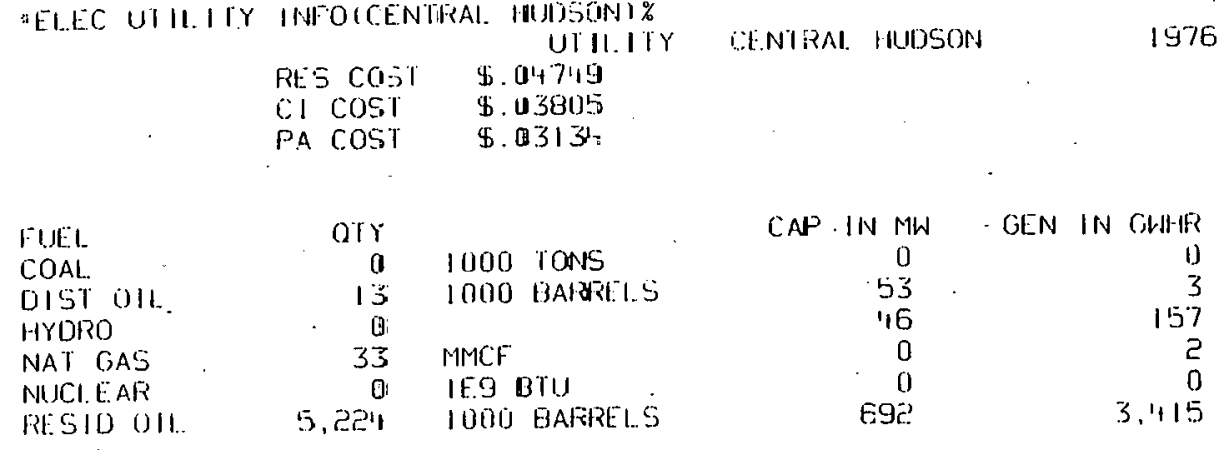

\begin{tabular}{|c|c|c|c|}
\hline $\begin{array}{l}\text { PA DEM } \\
\text { MINITR }\end{array}$ & $\begin{array}{l}\text { PA COST: } \\
\text { D/KINHF: }\end{array}$ & $\begin{array}{l}\text { ROTAL } \\
\text { MIINHIR }\end{array}$ & $\begin{array}{c}\text { AVE } \\
\text { S/LWWIR }\end{array}$ \\
\hline $\begin{array}{r}312.420 \\
735\end{array}$ & $\$ .0410 i 1$ & $\begin{array}{r}5.668,326 \\
13,019\end{array}$ & 5.04813 \\
\hline 313.155 & $\$ .04091$ & 5.681 .345 & $\$ .0^{4}+832$ \\
\hline
\end{tabular}

PA DEM PA COST

TOT AI.

$I^{A V E}$ 


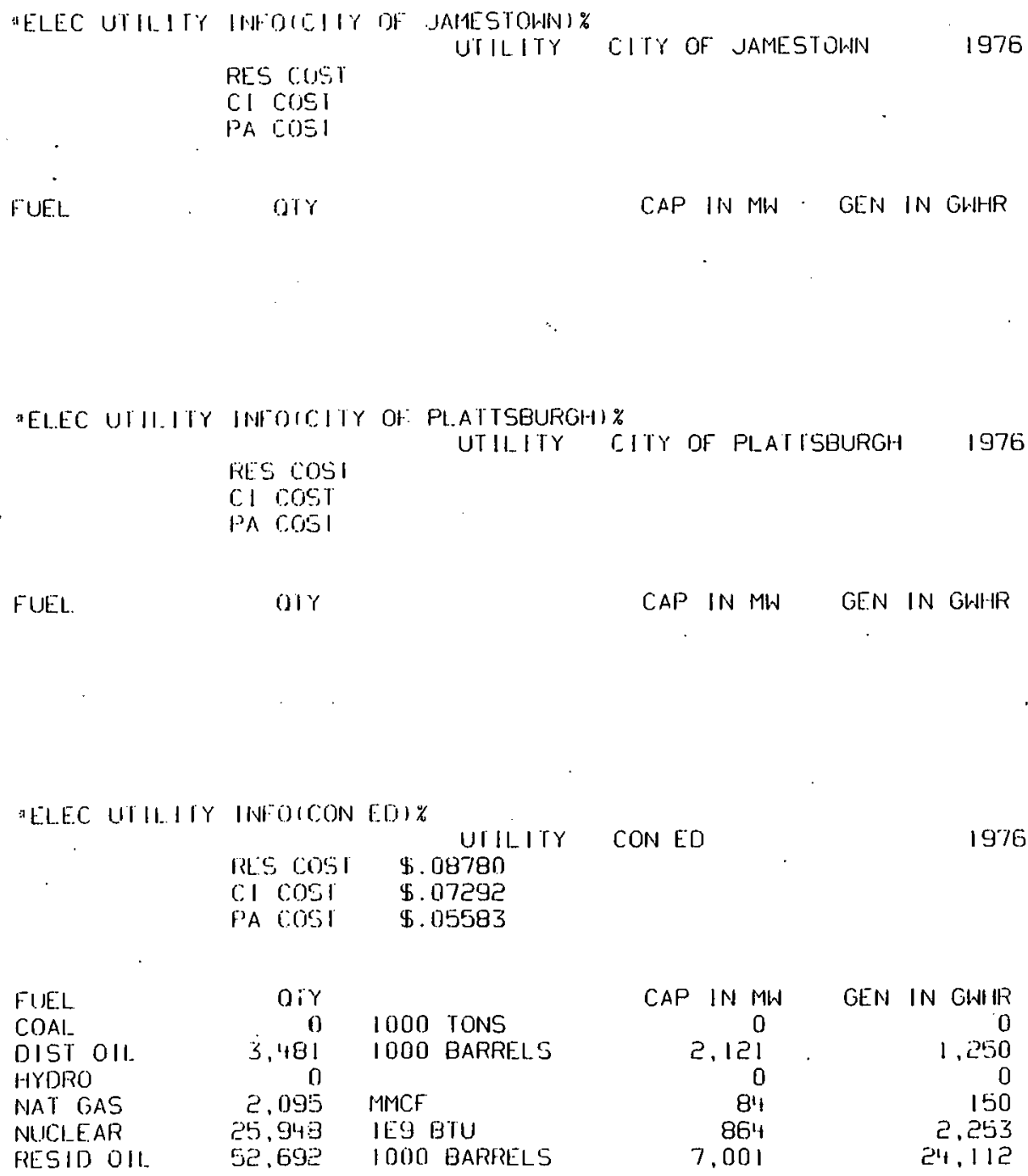


"EI.EO UTHLIT\% INUOLLLCOH\%

$\begin{array}{ll}\text { UTILITY LILCO } \\ \text { REJ } 0.051 & \$ .05191 \\ \text { CI COST } & \$ .04581 \\ \text { PA COOSI } & \$ .04101\end{array}$

PA COOSI

\begin{tabular}{|c|c|c|c|c|c|}
\hline FUEL. & orr & & CAP IN ML & GEN & IN SWHIR \\
\hline COAL. & 0 & 1000 TONS & 0 & & \\
\hline EIST 011. & 915 & IOOO BARTRELS & 1.204 & & 363 \\
\hline 1.YDPB & 0 & & 0 & & \\
\hline MAT GAS & $1,1.4$ & IIIACF & 0 & & 111 \\
\hline NUCLEAR & & IES BIU & $\mathbf{0}$ & & \\
\hline FiEID OHI. & 15,375 & 1000 BARRELLS & 2.523 & & 11.5 \\
\hline
\end{tabular}

ELEO UR II.I IT IMF OINIAGARA MOHAWK I\%

UTIIITY

NI ACJARA MOHALIK

1976

1k. 0.051 \$.03rug

i. 0051 \$. 02400

\begin{tabular}{|c|c|c|c|c|c|}
\hline \multirow[t]{4}{*}{ FUE. } & C.IY & & CAP IN MW & GEN II & $N$ GNAR \\
\hline & 0 & & 0 & & 0 \\
\hline & E. & & $2 \% 0$ & & 30 \\
\hline & 10.1117 & & 2,105 & & 6.1168 \\
\hline COAL. & 2.800 & 1000 TONS & 1.470 & & $\because .267$ \\
\hline HYYOR? & $0 \mathrm{i}$ & & 549 & & 3.59 \\
\hline WIII $=A R$ & 9יה", ויוי & IFG BIU & (5) & & 1.12 \\
\hline
\end{tabular}


- ELEC UTILITY INHOINYSE+G)\%

$$
\begin{array}{ll} 
& \multicolumn{1}{c}{\text { UTILITY NYSE }+G} \\
\text { RES COST } & \$ .03708 \\
\text { CI COST } & \$ .02941 \\
\text { PA COSI } & \$ .03184
\end{array}
$$

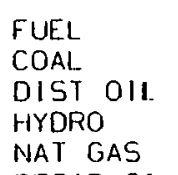

$\begin{array}{rl}\text { OTY } & \\ 354 & 1000 \text { TONS } \\ 200 & 1000 \text { BARRELS } \\ 0 & \\ 0 & \text { MICF } \\ 0 & \end{array}$

\section{CAP IN}

IN MW
1.375
13
1,0
0
0

GEN IN GINHR

7.239

250

0

"ELEC UIII 1IY INI IIORANDE + ROCKL ANOI\%

CRAIUGE +ROCKL ANII

1976

$$
\begin{aligned}
& \text { RES COSI \$. 06760 } \\
& \text { CI COS } 1 \text { \$. } 0531+0 \\
& \text { PA Cosi g.04789 }
\end{aligned}
$$

$\begin{array}{lrl}\text { FUELL } & \text { O1Y } & \\ \text { COAL } & 0 & 1000 \text { TONS } \\ \text { DIST OIL } & 1 & 1000 \text { BARRELS } \\ \text { HYDRO } & 0 & \\ \text { NAT GAS } & 1.9114 & \text { MMCF } \\ \text { NUCLEAR } & 0 & 159 \text { BTU } \\ \text { RESID OIL. } & 4.9 / 9 & 1000 \text { BARRELS }\end{array}$

CAP IN MW

0
74
44
0
0
902

BEN IN GWIIR

$$
\begin{array}{r}
0 \\
1 \\
223 \\
182 \\
0 \\
2.973
\end{array}
$$


QELE: UTIL ITY INE OAFASHAT\%

RES 2US!

CI cosi

PA COSI

\begin{tabular}{|c|c|c|c|c|c|c|}
\hline FUEL. & $01 Y$. & & CAP & IN MW & CLN & IN OWHF \\
\hline COAL & 0 & 1000 TONS & & 0 & & 0 \\
\hline DIST OIL & 0 & 1000 BARRELS & & 0 & & $\begin{array}{r}0 \\
529\end{array}$ \\
\hline HYOFPD & 0 & 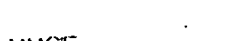 & & 3.200 & & 政 \\
\hline HAT DAS & 18 an & $\begin{array}{l}\text { MICF } \\
\text { IES BTU }\end{array}$ & & 1.643 & & $\because .524$ \\
\hline $\begin{array}{l}\text { PUUCLEAR } \\
\text { RESIO OAL }\end{array}$ & 0 & 1000 BARIRELS & & 0 & & \\
\hline
\end{tabular}

"ELEC UIII I IY IHFC(RG+E)\%

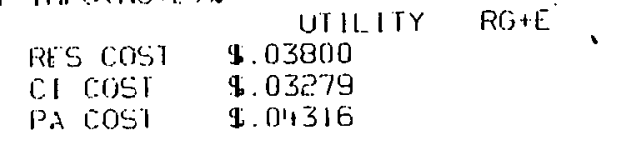

1976

\begin{tabular}{|c|c|c|c|c|c|c|}
\hline$=$ UEE. & or & & CAF & IN MlV & GEN & IN GWIIR \\
\hline$\therefore 0 \mathrm{AI}$. & 780 & 1000 TONS & & 340 & & 1.800 \\
\hline D/S1 0ll & $\vec{z}$ & 1000 BARRELS & & 14 & & 1 \\
\hline iHYDFO & 0 & & & 47 & & 260 \\
\hline NAT GAS & ck & MINCF & & 15 & & 1 \\
\hline NIUCIFAR & 2.3. 3100 & IE9 ETU & & 470 & & 2.000 \\
\hline RESIO (III & 250 & $10 D 0$ BARRELS & & 112 & & 110 \\
\hline
\end{tabular}

RESID 011 250 1000 BARRELS

FE EL U\|\|IIY INHOIVIILAGE OF FREEPORTI\%

UTILITY VILLAGE OF FREEPORT 1976
COSCOSI
PACOSI
CAP IN MIN GEN IN GHHR


*GAS MUNICIPAL. S:\%

\begin{tabular}{|c|c|c|c|}
\hline & MUNICIPAL & GA'S & UTIL.ITIES \\
\hline MUNICIPAL. & COUNTY & & $\begin{array}{r}\text { TOTAL SALES } \\
\text { MCF }\end{array}$ \\
\hline BATH E+G & STEUBEN & & 774,000 \\
\hline FILMORE GAS & ALLEGANY & & 185.000 \\
\hline GRANYBY+HEMENWAY GAS & ONTARIO & & 10,000 \\
\hline RESERVE C.AS & & & 220,000 \\
\hline VALLLEY GAS & LIVINIGSTON & & 32,000 \\
\hline WOODHULL & STEUBE.N & & 46.000 \\
\hline TOTALS & & & $1,267,000$ \\
\hline
\end{tabular}

"GAS RESFLE (BROOKI.YN UNION)

CAS RESALE FFOM UTIL.ITY BROCLKI.YN UNION

UIIL.ITY DOES NOT RESELL GAS

"GAS RESALE. (CENIRAL HIIISON)\%

GAS RESALE FROM UTHITY

CINIRAL HUISTON

UII.ITY DOES NOT RESELL. GAS

:GAS RESALEICOLIMHBIAI\%

gAS RESALE FROM WITILITY

COLUNESIA

WIIIIY DOES NOT RESELI. GAS 
"GAS RESALE ICON EDI\%

GAS RESALE FFOH UTILITY CON ED UTILITY DOES NOT RESELL GAS

"GAS RESALE (CORNING)\%

\section{GAS RESALE FROM UTILITY COFNING}

$\begin{array}{cc}\text { NAME } & \begin{array}{c}\text { OUANT ITY } \\ \text { MCF }\end{array} \\ \text { MYSE-G } & 9,975.675 \\ \text { TOTAL } & 9,975.675\end{array}$

*GAS RESALE (L ILCO):

GAS RESAIE FROM UTILITY LILCO

UTLITY DOES NOT RESELL GAS

"GAS FESALE (NATI JNAL FUEL):

GAS RESALE FRDM UTII-ITY NATIONAL FUEL

$\begin{array}{lc}\text { NAME } & \begin{array}{c}\text { QUATIITY } \\ \text { MCF }\end{array} \\ \text { OTHEER } & 4.775 .301 \\ \text { TOTAL } & 1,775,301\end{array}$


- Gas Resa e (NIAGafa moinahki\% GAS RESALE FROM UTILITY

NIAGARA MOHALNK
NAME

$\begin{array}{lr}\text { NYSE }+G & 214,614 \\ \text { SYRACUSE } & 3.496,920 \\ & 3.711,534\end{array}$

*GAS RESALE (NYSE+G)\%

NAME

OTHER

TOTAL
DUANT I IY

MCF

3.711 .534 $\stackrel{0}{1}$
GAS

OUANTITY

MCF

i.,925

1,925
RESALE FROM UTILITY NYSE. +G

\section{MTIT}

628.216

996,340 
"gas fResal.e. IPAV ILLLIONI\%

$\begin{array}{cc}\text { NAME } & \begin{array}{c}\text { DUANITY } \\ \text { MCF }\end{array} \\ \text { OTHER } & 25.270 \\ \text { TOTAL } & 25.270 .\end{array}$

"gas feEsale (PENN+SOUTH)\%

GAS RESALE FROM UTILITY UTILITY DOES NOT RESELL GAS

\section{"GAS :ESA E (ROTEI\%}

gAS RESALE FROM UTILITY Rö+E

UTIITY DOES NOI RESELL GAS
*GAS RESGIE(:3T. LAWRENCE)\%

GAS RESALE FROM UTILITY
GAS
ST. LAWRENCE 
*gaS RESAi_e (PAVILL IONI)\%

NAME
GUANTITY
MCF
OTHER
TOTAL
25.270

RESALE FROM UTILIIY PAVILLION.

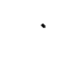

"GAS RESAIE (PENN.SOUTH\%

\section{GAS}

RESALE FROM UTILITY

PENN+SOUTH

UTILITY DOES NOT RESELL GAS

$\Rightarrow$ GAS RESALE (RGHE):

CAAS RESALE FROM UTILITY

$R G+E$

UTII.ITY DOES NOT RESELL GAS

* gas resaleisi. I.alhrenCe 1\%

GAS RESALE FROM UTIL.ITY

ST. I. AWRENCE 
"DAS RESHLE ISIRALUSE SUBUPAAM:\%

TIAME CIJANTITY
MCF

OTHER

10,925

iOTAL.

10.925

-gas supalyibRojki. yn UnIOHIz

NAME

TYPE

$$
\text { QUANTITY }
$$

\section{DTHEF}

PRuDUCTION

DISTRI CAS

TENNESSEE
TEXAS-EASTEFAN

PIPEL INE

PIPEL INE

PIPELINE

PI DEL. INE

\section{TOTELS}

b? 470

\$2. 167

$\$ 1.089$

$\$ 1.432$

$\$ 1.123$

$\$ 1.11,11$

"GAS SUPPL TiLCEHTRAL IIIIISCNO.\%

NAME

PrPE

COLUMBIA NAT

TE.NNESSEL

TEXAS-E.ASIERN

rorats

\section{QUANTITY}

$\mathrm{COS}^{\circ}$

FH:ODUCTION

PIPELLINE

PIPEI. INE

PIPEL INE

\section{MiF}

$3,189,2148$

3.189 .248

$4.069,697$
1. 160,995

8.421 .602
$9 / \mathrm{MCF}$

bI. 200

b) .200
$b 1.130$

$\$ 1.170$

$\$ 1.162$ 
*GAS SUJPPL YICOL UIJIAI\%

$\begin{array}{ll}\text { NAME } & \text { TYPE } \\ & \\ & \text { PRODIJCTION } \\ & \text { OTHER } \\ \text { COLUMBIA NAT } & \text { PIPELIINE }\end{array}$

TOTALS

- gas SIJPPLy(CON tod)

NAME

$\begin{array}{ll}\text { ALGONOUIN NAT } & \text { PIPELINE } \\ \text { TENNESSEE } & \text { PIPLL INE: } \\ \text { IEXAS-EASTERN } & \text { PIPEL INEE } \\ \text { TRANSCONTINENIAI. } & \text { PIPELI INEE }\end{array}$

IEXAS-EASTERN PIPELINE

TOTALS UPP
IO UTHLIIY COLUIBIA

UUANTIIY

$\mathrm{MCF}$

\begin{abstract}
713
169,037
9.491 .415
19.491 .415
\end{abstract}

$19.561,165$

$19,661,165$

3

b/NF

$4) .570$

$\$ 1.198$

$\$ 1 . \bar{c} 10$
1976

.

"CAS SUPPI YICORIMINGI\%

NAME:

IYPE

PIPELINE

COI. UMBIA NAT

CONSOL. IDATED

PIPEI. INE

NORTHI PENN

OTH IEP

$101 \mathrm{Al} 5$
SUPPLY TO UTILITY COFNINO,

RUANTITY

MCF

CON ED

1970

OUANTITY
MCF
701.371
$11,028,479$
$17,492,004$
$60,998,598$

$90,220,552$

$\cos 1$

$\Phi / \mathrm{MCF}$

$4 r^{\circ} \cdot 164$

$\$ 1.095$

$\$ 1.263$

$\$ 1.024$

\$1. 0838

1976

$9 / \mathrm{MCO}$

431.375
1.174 .553
14.136 .661


"GAS S.JPPLYLLII.C11)\%

$\begin{array}{ll}\text { NAME } & \text { TYPE } \\ & \\ \text { TERMESSEE } & \text { PRODUETION } \\ \text { TEXAS-EASIERM } & \text { PIFELINE } \\ \text { TRANSCONTILENTAL } & \text { PIFELIIIE } \\ \text { PIFELINE }\end{array}$

TOTALS

.

SLPPLY TO UTILITY LILCO

$$
\text { OUANTITY }
$$

MCF

$$
\begin{array}{r}
2.500 \\
1.403 .781 \\
5.096 .428 \\
37.957 .637
\end{array}
$$

$44,160.346$

\section{6}

$\cos T$ $\$ / \mathrm{MCF}$

$\$ 1.210$

$\$ 1.360$

\$1 . 120

$\$ 1.150$

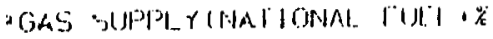

NATIE:

IYPE.

OUJANI ITY

$\cos 1$

ASHIAND SYT

CCH.UMEIA SYN

PIPELINAL

PIPEL INE:

NATICNAL.

PIPEL INE

TOTALS

"GAS SUPFI.YINIAGARA MOH+ANKI:

NAIE

BORCIE RL. INE.

CONSOL IDATED

TYPE

PIPELIINE

PIPEL INE
OUANTITY

$\mathrm{COST}$

TOTALS
MCF

10,878

$* 3,612,276$

$* 3,623,154$
9.1 .200

\$) . 200
$11,600,000$

180.000

" $2,639,000$

$\$ 3.261$

$\$ 4.406$

$\$ 1.204$

$24,419,000$

91.362 
"GAS SUPPI. Y (NYSE +G)\%

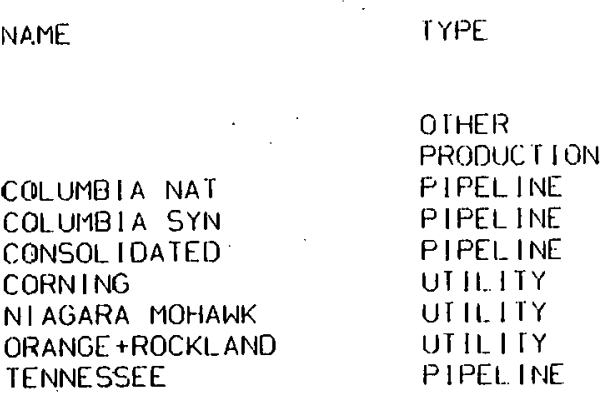

TOTALS

\section{SUPPLY TO UTILITY NYSE+C}

1976

$\begin{array}{rc}\text { QUANTITY } & \text { COSI } \\ \text { MCF } & \text { \$IMCF } \\ 10,000 & \\ 30.698 & \$ 1.870 \\ 641.053 & \$ 1.290 \\ 39,212 & \$ 1.350 \\ 25.365 .919 & \$ 1.140 \\ 9.976 .675 & \$ 1.190 \\ 214.614 & \$ 1.730 \\ 368,124 & \$ 1.1140 \\ 5.598,660 & \$ 1.020 \\ 42.24 \% .955 & \$ 1.146\end{array}$

"GAS SUPPLYIORANGE +ROCKL.ANDI\%

GAS

NAME.

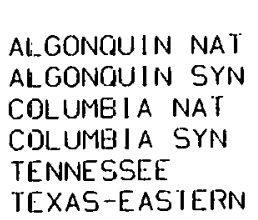

TEXAS-EASIERN

TOTALS
TYPE

\section{PRODUCTION}

PIPELIINE

PIPELINE.

PIPELINE.

PIPEL INE

PIPELINE.

PIPELINE

SuPF

SUPPLY TO UTHLITY

$$
\text { QUANTITY }
$$

$\cos t$

MCF

$$
\begin{array}{r}
102.611 \\
1.215 .761 \\
463.557 \\
8.493 .559 \\
467.876 \\
14.499 .766 \\
1.032 .913
\end{array}
$$

$26.276,046$
$\$ 1.700$

$\$ 5.250$

$\$ 1.210$

$\Phi 14.300$

$\$ 1.060$

\$1. 170

$\$ 1.270$

"JAS SUPPLYIPAVILLIONI\%

NAME

CJNSOI. IDATED

TOIALS
TYPE

PIPEL INE
QUANT ITY
MCF

$3,120.706$

$3,120.706$ $\cos T$ I/MCF

$\$ 1.137$

41.137 
-GAS SUPFLYYSIRACISE SUJBJURBANI:

$\begin{array}{lccc}\text { NAME } & \text { TYPE } & \text { QUANTITY } & \text { COSI } \\ \text { MCF } & \$ / M C F\end{array}$

"GAS UTILITY INFGRBROOKL YN UNICNI\%

GAS. UTILITY INFORMAIION FOR UTILITY BROUKLLN UNION

1576

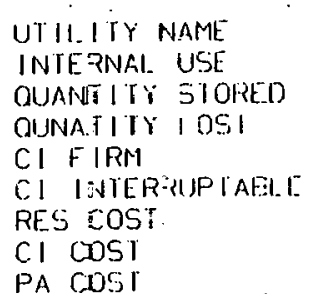

BFOOKLI.YN UNION

$696,672 \mathrm{MCF}$
$\bar{E} .716 .555 \mathrm{MCF}$

C. $716,5=5 \mathrm{MCF}$
$\mathrm{E}, 538,145 \mathrm{MCF}$

$14,001,255 \mathrm{MCF}$

E. 317, IE MCF

$317,1 C 1 \mathrm{MCF}$
$\$ 3.7 \% 0 / \mathrm{HCF}$

$\$ 3.7 E 0 / \mathrm{MCF}$
$\$ 3.190 / \mathrm{MCF}$

PA COST \$2.7Е0/MCF

* Gas UTH. itr infoicentral huDSUni:

GAS

UTII. ITY INFORMATION FOR UTILITY CENTRAL. HUDSON

CENTTRAL HUDSON

JILITY NAME

INTERNAL WSE

DUAMTITY STORED

OUNATITI I.OST

CI FIRIM

CI UINTERFILPTABIE

RES COST

CI COST

88, $723 \mathrm{MCF}$

0 MCF

$317.221, \mathrm{MCF}$

$2.139 .438 \mathrm{MCF}$

$.683 .374 \mathrm{MCF}$

$\$ 3.250 / \mathrm{MCF}$

$\$ 2.030 / \mathrm{MCF}$

$\$ 1.990 / \mathrm{MCF}$ 
UT ILITY NAME

QUANTITY STORED

QUNATITY LOST

CI FIRIY

CI INTERRLP TABIL E

RES COST

CI COST

"GAS UTILITY INFOICON EUI\%

UTILI TY NAME

INTERNAL USE

OUNATITY L.OST

CI FIRM

RES COST

C1 $\cos$

PA COSI
COL UHIBIA

$$
\begin{array}{r}
14,527 \mathrm{MCF} \\
0 \mathrm{MCF} \\
270.521 \mathrm{MCF} \\
6,158,524 \mathrm{MCF} \\
4,583,099 \mathrm{MCF} \\
72.225 / \mathrm{MCF} \\
91.635 / \mathrm{MCF}
\end{array}
$$

.

GAS

WIIIITY INFORMATION FOR UTILITY

CON ED

1976

CON ED

$$
\begin{array}{r}
3.836 .665 \mathrm{MCF} \\
5.06 \% .271 \mathrm{MCF} \\
8.366 .75 \% \mathrm{MCF} \\
21.069 .821 . \mathrm{MCF} \\
9.326 .170 \mathrm{MCF} \\
914.260 / \mathrm{MCF} \\
92.900 / \mathrm{MCF} \\
42.170 / \mathrm{MCF}
\end{array}
$$

"GAS UTIL ITY INFO(CORNING)\%

UTILITY NAME
INTERNAL USE
CUANTITY STORED
QUNATITY LOST
CI FIRM
CI INTERRUPTABLE
RES COST
CI COST
PA COST

$$
\begin{array}{r}
3.506 \mathrm{MCF} \\
0 \mathrm{MCF} \\
44.705 \mathrm{MCF} \\
386.938 \mathrm{MCF} \\
0 \mathrm{MCF} \\
\$ 1.538 / \mathrm{MCF} \\
\$ 1.304 / \mathrm{MCF} \\
\$ 1.447 / \mathrm{MCF}
\end{array}
$$$$
3.386 .938 \mathrm{MCF}
$$ 
"GAS UTII ITY INTULIRCOI:

GAS

UT ILITY NAME

QUAFTISY STITREG

QUNATITY LOOT

CI HI IRM

CI INTERIRUPI LEEI.F

RES I:OOST

C) $\cos 5$

L. II. CO

2. $528,5 E 6 \mathrm{MCH}$

$9,50 E, 323+1 C F$

כ. $63 \frac{3}{2}, 150 \mathrm{MCF}$

I3, $270,3+16$

2. $108,33311 \mathrm{MCF}$

$\$ 2.360111 C$

$\$ 5.730 / 11 \mathrm{H}$

"GAS UTILITY INHOINAI IOHAL FUEII\%

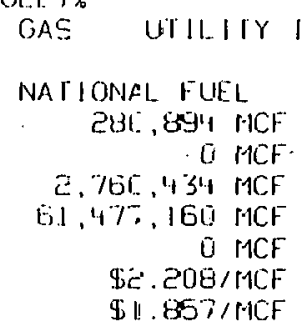

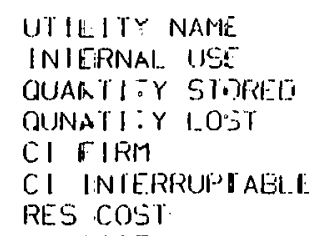

\begin{tabular}{|c|c|}
\hline UTIL.ITY NAME & NIAGAR/ MOHALKK \\
\hline INTERRNAL USF & $13 \% .628 \mathrm{MCF}$ \\
\hline OUARTITY STIBREE & $0 M C F$ \\
\hline OUNATITY LOST & .826. MCF \\
\hline CI FIRM & $.076 \mathrm{MCF}$ \\
\hline CI INTLRRUPIAELE: & $15,67 \bar{z}, 141 \mathrm{MCF}$ \\
\hline RES COST & $\$ \overline{\mathrm{c}} \cdot 330 / \mathrm{MCF}$ \\
\hline CI COST. & $\$ 1.900 \mathrm{R} / \mathrm{MCF}$ \\
\hline
\end{tabular}

-GAS UTII. ITY INFOINI GGAFA MOHAWKI\% GAS 
"GAS UTILITY INFIJINYSEE 1

CAS UTII.ITY INFORMATION FOR UTILITY NYSENG

1976

UT.LIIY NAII:

IN ERINAA. USE:

QUANTI IY STORETS
OUNATITY LOST

QUNATITY

CI INTERRUPTABLE

WYSE+C

93,078 MCF

0 MCF

$875,125 \mathrm{MCF}$

$17,365,661 \mathrm{MCF}$

861, . $18 \mathrm{MCF}$

\$ट $079 / \mathrm{MCF}$

\$1. $674 / \mathrm{MCF}$

q1. $653 / M C F$

"GAS UTILITY INFOIORANGL +ROLKLANDI\%

CIAS UIILITY INFORHATION FOR UTILITY URANGE+ROCKLAND
ORANGE. HOCKLAND
$495,556 \mathrm{MCF}$
$0 \mathrm{MCF}$
$56.700 \mathrm{MCF}$
$4.751 .294 \mathrm{MCF}$
$1.357 .628 \mathrm{MCF}$
$\$ 2.390 / \mathrm{MCF}$
$\$ 1.880 / \mathrm{MCF}$

1976
UTILITY NAME
INTERTAL SSE
DUANTITY STORTD
QUNATITY
CI FIRM
RES COST
CI $\cos { }^{\circ}$

GAS UIILITY INFOORAVILLIONI

\section{GAS UTILITY INFORMATION FOR UTILITY FAVILLION}

PAVILLION

$$
\begin{array}{r}
7.000 \mathrm{MCF} \\
0 \mathrm{MCF} \\
100.000 \mathrm{MCF} \\
132.136 \mathrm{MCF} \\
0 \mathrm{MCF} \\
\$ 1.910 / \mathrm{MCF} \\
\$ 1.603 / \mathrm{MCF}
\end{array}
$$

$\begin{array}{lr}\text { INTERNAL USE } & 7.000 \mathrm{MCF} \\ \text { QUANTITY STORED } & 0 \mathrm{MCF} \\ \text { OUNATITY LOST } & 100.000 \mathrm{MCF} \\ \text { CI FIRM } & 132.136 \mathrm{MCF} \\ \text { CI INTERHUIPTABIEE } & 0 \mathrm{MCF} \\ \text { RES COSI } & \$ 1.910 / \mathrm{MCF} \\ \text { CI COST } & \$ 1.603 / \mathrm{MCF}\end{array}$




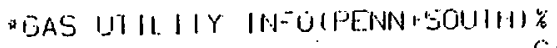
UIILITY NAFE
INTERNAL UCE
GUANTITY STOREE
QUNATITY LCOS
C) FIFM
CI INTERRUF'TAB_E
RES COSI
CI $: 0 \leq$ ?
PENAS SDU H
$585 \mathrm{MCF}$
$\mathrm{MCF}$
$103.1781 \mathrm{MCF}$
$3: 1 \mathrm{MCF}$
$\$ 2.225 / \mathrm{MCF}$
$\$ 1.99 \mathrm{I} / \mathrm{MCF}$

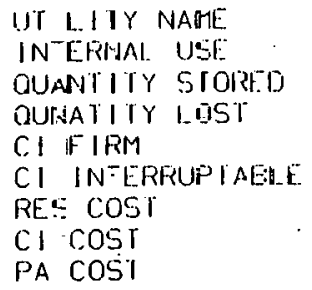

$\mathrm{RC}+\mathrm{E}$

$$
\begin{array}{r}
1.2 \leq 1,0 \equiv 5 \mathrm{MCF} \\
0 \mathrm{MCF} \\
1.8 \leq 3.0 \equiv 7 \mathrm{MCF} \\
15.249 .259 \mathrm{MCF} \\
0 \mathrm{MCF} \\
\$ 2.450 / \mathrm{MCF} \\
\$ 1.8910 / \mathrm{MCF} \\
91.930 / \mathrm{MCF}
\end{array}
$$

¿GAS UIIL ITY INFOIST. L.AWRENCE I\%

GAS WTILITY INFORMATION FOR UIII.ITY ST. LAHFETCE

$$
\begin{aligned}
& \text { UTILITY NAME } \\
& \text { INERNAL LSE } \\
& \text { OUANTITY } \subseteq \text { TORED } \\
& \text { QUNATITY LOOST } \\
& \text { CI.FIRM } \\
& \text { CI INTERPLPTABIE } \\
& \text { C) TNTER }
\end{aligned}
$$

HFETICE

$5,8: 91 \mathrm{MCF}$

$0 \mathrm{MCF}$

15. $1.38 \mathrm{MCF}$

$3.15 ? .140 \mathrm{MCF}$

814. (14.3. MCF

Б2 $810 / M C F$

D2 $\cong \mathrm{EO} / \mathrm{MCF}$ 


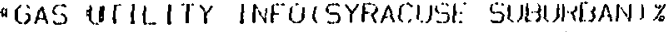

$$
\text { GAS UIILIIY INFORMATION FOR. UTILITY SYRACUSE SUIBURIBAN }
$$

UTILITY NAME

INTERNAL. USE

QUAANTITY STORL
QUNATITY I.OSI

CI FIFIM

CI INTERPUPTABILE

RES COSI

ci cost
SYRACIJI: SIJBURBAN
$1.195 \mathrm{MCF}$
O MCF
3 gा .933 MCF
$0 \mathrm{MCF}$
$\$ 1.9 \% \mathrm{MCF}$
$\$ 1.615 / M C F$


"IVYPPICENTRAL. HUISSONI\%

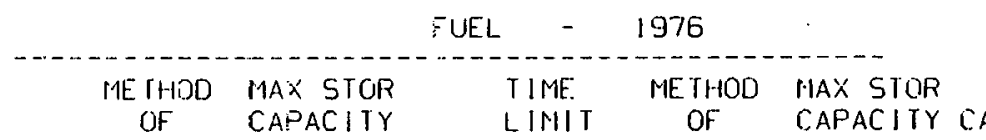

UNIT AVERAGE

AVAILABLE HEAT RAIE COIPANY STATION UNIT LOCATICN IYYEE PËI HANDLING (XIOOOI ALT ON USE HANDLING IXIOOO) SUAMTER NINTER SYSTEM+

CENTRAL H" DANSKAMIIER I NEWBJRGH SI $5=33 \quad 485 \mathrm{BBL}$

CENTRAL H* DAISKAMMER 2 NEWEOPCH

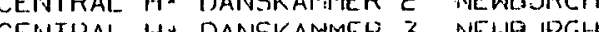

CENTRAI $H *$ DANSKAMMER 4 INEWE3.JRCH

CENTRAL H" ROSETON I NEWBJRCH

CENIRAL H: ROSE ION 2 NEWBUURCH

CENTRAL H* DANSKATMER 5 NEWESURCH

CENIRAL $H^{*}$ DANSKAIMMEF 5 NE UIBA JRGH

CENTRAL H: DASHVII.LE I RIF DN

CENTRAL H* DASHVILILE ? RIF"ON

CENTRAL H* MEVIRSINK

Q CENTRAL. H* STURGEON
1 CENIRAL H" STURGEON

CENTRAL H" STURGEON

CENTTRAL H" STURCEON

CENTRAL H: COXSACFIE

I RIFTON

2 RIITON

COX:ACr:IE

CAIf:O

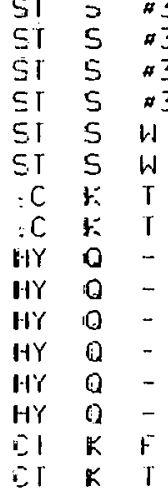

CENIRAL $\mathrm{H}^{2}$

215 BBLS

ac

$\therefore$ EBL.S

-
-
-
-
$\cdot$.
..
1.23 BI.S
10.5 BBI

$-\quad$

$\$ 3$

...........

$\begin{array}{rrr}35 & 39 & A \\ 6 E & 66 & A \\ 118 & 118 & A \\ 229 & 229 & A \\ 120 & 120.1 & A \\ 120 & 120.1 & A \\ 2.5 & 2.5 & C \\ 2.5 & 2.5 & C \\ 1.5 & 1.9 & - \\ 1.5 & 1.9 & - \\ 27 & 2 \% & - \\ 1.9 & 5.0 & - \\ 1.9 & 5.11 & - \\ 1.9 & 5.0 & - \\ 19 & 211 & C \\ 19 & 21 & C\end{array}$

TOTAL. CENTRAL HUDSON

CT - COMBUSTION TURBINE

HY - CONVENIIOAL HYORO

IC - INTERNAL COMBIISTION

ST :- STEAM TURBINE (OII.)

$7.592 \quad 11.728$

$5.789 \quad 10.640$

$5.000 \quad 10.247$

$8.442 \quad 9.692$

$\begin{array}{ll}5.683 & 9.798\end{array}$

$6.890 \quad 9.798$

$8.764 \quad 15.1+66$

$8.767 \quad 15.466$

$-$

8.77114 .162

8.03913 .770

$\begin{array}{rr}34 & 183 \\ 15 & 46 \\ 5 & 5 \\ 638 & 692 \\ 780 & -731\end{array}$

NOIF "1 . ROSEIGN ACI IAL CAPAE IT" $151200 \mathrm{MW}$. CEINTRAL HIJDSONIS SHARE IS 210 MW.

NOIE "C. - ROSETON RESIDUAI STORAGE CAPACITY - 1079 MMBLS 20 OIL - $33.411 M B S$.

NUIE W3 - DII. DEI.IVERED IO TIE PLANT VIA PIPEL INE. FROM SIJPFLIERS IERMINAI.. 
"NYPPICON EDI)\%

rUE.I.

$19 ; 6$

UNI!

AV'ERACE:

METHOO MAX STOR TIME METHOOS MAX STOR TYPE UF AVAIL ABHL IIEAI RAIE

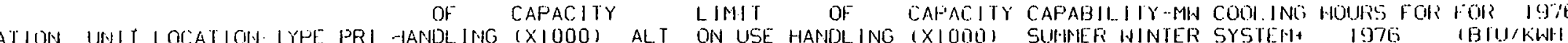

CON ED

CON ED

CON ED

CON ED

CON ED

CON ED

CON ED

CON ED

CON ED

CON ED

CON ED

CON ED

CON ED

CON ED

CON ED

CON ED

CON ED

CON ED

CON ED

w CON ED

in CON ED

CON ED

CON ED

CON ED

CON ED

CON ED

CON ED

CON ED

CON ED

CON ED

CON ED

CON ED

CON EO

CON ED

CON ED

CON ED

CON ED

CON ED

CON E.D

CON ED

CON ED

CON ED

CON ED

CON E.D

CON ED

CON ED

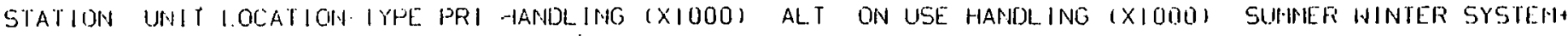
1976 $18 \mathrm{Bl} / \mathrm{kinl|}$

\begin{tabular}{|c|c|c|c|c|c|}
\hline ARTHUR KI: & ي & STAIEN 15 & $\mathrm{sl}$ & $\mathrm{S}$ & $i$ \\
\hline ARIHURR KI" & 3 & STATEN IS & SI & $s$ & $\mathrm{~T}$ \\
\hline ASIORIA & 1 & QUEENS & $5 \mathrm{~T}$ & $\mathrm{~S}$ & $=. B$ \\
\hline ASTORIA & 2 & DUEENS & ST & 5 & \\
\hline ASTORIA & 3 & QUEEENS & ST & $\mathrm{S}$ & $=. B$ \\
\hline ASTORI'A & 4 & OUEENS & $5 T$ & 5 & \\
\hline ASIORIA & 5 & OUEENS & SI & $S$ & $\lambda$ \\
\hline BOWl. I NF. & 1 & HAVERSIRAW & SI & 5 & .4 \\
\hline BOHL_INE & 2 & HAVERSTRAW & ST & 5 & \\
\hline EAST RIVER & 5 & MANHATTAN & $\mathrm{st}$ & 5 & \\
\hline EASI RIVER & 6 & MANHATIAN & SI & $\mathrm{s}$ & $=$ \\
\hline EASI RIVER & 7 & HANHIA I IAN & ST & $\mathrm{s}$ & \\
\hline HUDSON AV: & $\approx \mathrm{A}$ & & ST & $\mathrm{S}$ & N \\
\hline RAVENSWOOD & 1 & OUEENS & ST & 5 & $\bar{\varepsilon}$ \\
\hline RAVENSINOOD & 2 & OUEENS & $\mathrm{ST}$ & $S$ & \\
\hline RAVENSWOOD & 3 & QUEENS & 51 & $\mathrm{~s}$ & $\ddot{r}$ \\
\hline ROSEIDN & 1 & ROSE TON & 51 & $\mathrm{~S}$ & N \\
\hline ROSETON & z & ROSE TON & S1 & $S$ & $w$ \\
\hline WATERSIDE & 7 & MANIIAT I AN & ST & 0 & r" \\
\hline WAIERSIDE & $a \beta$ & MANHIATIAN & Sit & 5 & $\mathrm{r}$ \\
\hline WA IERSIDE- & $\# C$ & MANIHAT IAN & SI & 5 & $F$ \\
\hline $59 \mathrm{ST}$ & 40 & MANIIATIAN & $\mathrm{ST}$ & $\mathrm{s}$ & W \\
\hline $7+51$ & $\| E$ & MANIIA I TAN & 51 & $\mathrm{~s}$ & $F$ \\
\hline INIIIAN $P O *$ & 1 & BUSCHANAN & $S P$ & 1 & $\omega$ \\
\hline INDIAN PO: & 2 & BUCHANAN & $S P$ & $N$ & - \\
\hline ARTHERR KI* & & STATEN IS & C. & 5 & 1 \\
\hline ASTORIA & nI & OUEENS & $\mathrm{Cl}$ & $G$ & $F$ \\
\hline ASTORIA & 05 & OUEENS & $\mathrm{Cr}$ & 5 & IN \\
\hline ASIORIA & 06 & & $\mathrm{CI}$ & & - \\
\hline ASIORIA & 07 & & $\mathrm{Cl}$ & & - \\
\hline ASTORIA & 08 & & $\mathrm{Cr}$ & & - \\
\hline ASTORIA & 09 & & $\mathrm{Cl}$ & & - \\
\hline ASTORIA & 10 & & C $\mathrm{CT}$ & & - \\
\hline ASTGRIA & 11 & & $\mathrm{CT}$ & & - \\
\hline ASIORIA & 12 & & $\mathrm{Cl}$ & & - \\
\hline ASIORIA & $\mu F$ & QUEENS & CT & $\mathrm{k}$ & IN \\
\hline GONANISS & $\# \mathrm{G}$ & BROOKILYN & $\mathrm{CT}$ & 5 & $\mathrm{~W}$ \\
\hline HUDSON AV: & 1 & BROOKL.YN & $\mathrm{CI}$ & $k$ & $\mathrm{~T}$ \\
\hline HUDSON AV: & 2 & BROOKL YN & CT & $\mathrm{K}$ & $r$ \\
\hline HUDSON AVX & 3 & BROOKI. YN & $\mathrm{Cr}$ & K & r \\
\hline HUDSON AV* & 4 & BROOKI_Y YN & $\mathrm{CT}$ & K & $T$ \\
\hline HUIOSON AV: & 5 & BROOKI.YYN & $\mathrm{Cr}$ & $k$ & $\mathrm{~T}$ \\
\hline INDIAN POE & 1 & BUCHANAN & $C T$ & $k$ & $\omega$ \\
\hline INOIIAN POA & 2 & BUCHANAN & $\mathrm{CT}$ & K & 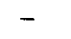 \\
\hline$|N| T \mid A N P O *$ & 3 & BUCHANAN & $\mathrm{Cl}$ & k & - \\
\hline KENI AVE & 2 & BROOKI.YN & $\mathrm{CI}$ & k & $\uparrow$ \\
\hline NARROWL $B$ & & & & & \\
\hline
\end{tabular}

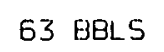

NONE

C NONE IV

ac

$\begin{array}{lll}\text { \#S } & \text { G.C NONE } \\ \text { a. C NONE } & F, W\end{array}$

C N NONE F.N

$\begin{array}{ll}C & \text { NONE } \\ C & \text { NONE }\end{array}$

42
417

.17

$\div 3$

$+3$

$\because 3$

\#ए

" 15

$\sim 15$

43

43

35 BBLS

108 BBHS

z BBLS

48 BELS NONE - W

NONE $F$

$G$ NONE F.W

NONE -

$G$ NONE

G NONE

NONE -

NONE

NONE

NONE

$-F$

NONE - H

NONE - W

NDNE - 1

NONE - $F$

\begin{tabular}{|c|c|c|c|}
\hline 48 & $B B I_{-} 5$ & $G$ & NONE \\
\hline 100 & BBI..S & NONE. & -. \\
\hline 3 & BBI. S & NDHE & - \\
\hline 3 & BBL_S & NONE & - \\
\hline & & & - \\
\hline G & BEILS & NONE: & - \\
\hline 2 & .5 & MONE & - \\
\hline & 0 & & NONE \\
\hline
\end{tabular}

T2+3 BHIS 6 NONE

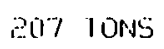

at

$\begin{array}{llll} & 151 & 161 & A \\ 41 & 161 & 164 & A\end{array}$

य1 161.161 A

a4 370 उ

$\begin{array}{lll}41 & 379 & 3137 \mathrm{~A}\end{array}$

4. 350

416

$\begin{array}{llll}916 & 101 & 101 & A \\ 416 & 1100 & 1100 & A\end{array}$

NONE $\quad 130 \quad 134$ A

NONE: 130 1314 A

NÜNE $166 \quad 170 \wedge$

193
$-415 \mathrm{~A}$

NCINE HOS $110 \mathrm{~A}$

NONI 101 $106 \mathrm{~A}$

NONE $9 \%$ 9\%? A

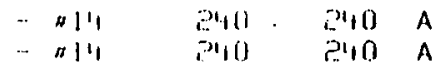

-. A

li.3 126 A

117 147 A

0 . 130013 A

B(i' BE' A

$\begin{array}{lll}15 & 18 & C \\ 15 & 18 & C\end{array}$

lif $20 \mathrm{C}$

II 20

11320

$.11 \quad 15$

16i 20

$1 ! 1$
$1 \%$

क.

46

1.

1

1.5

111

11
19

21

NARROW' $B$ : at BROOKL ON

C.

7.109
70.177

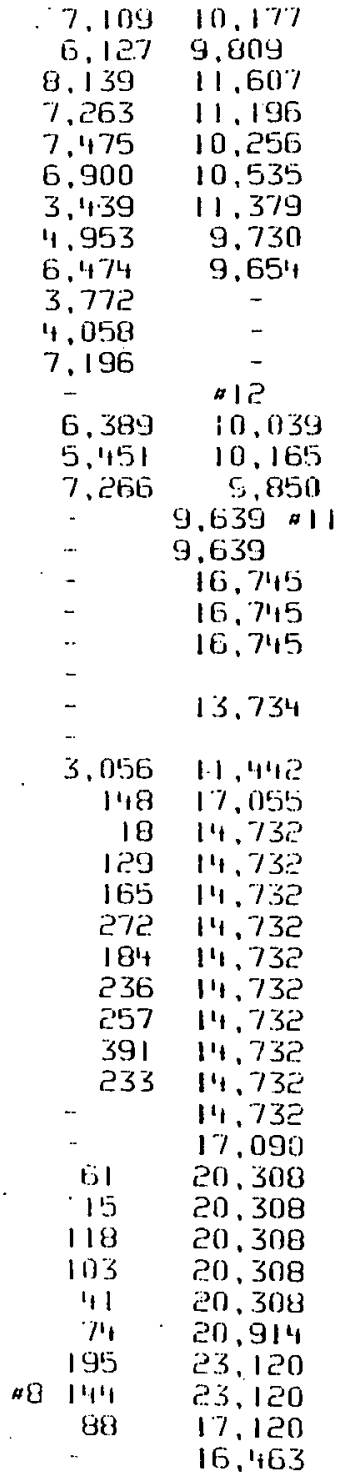




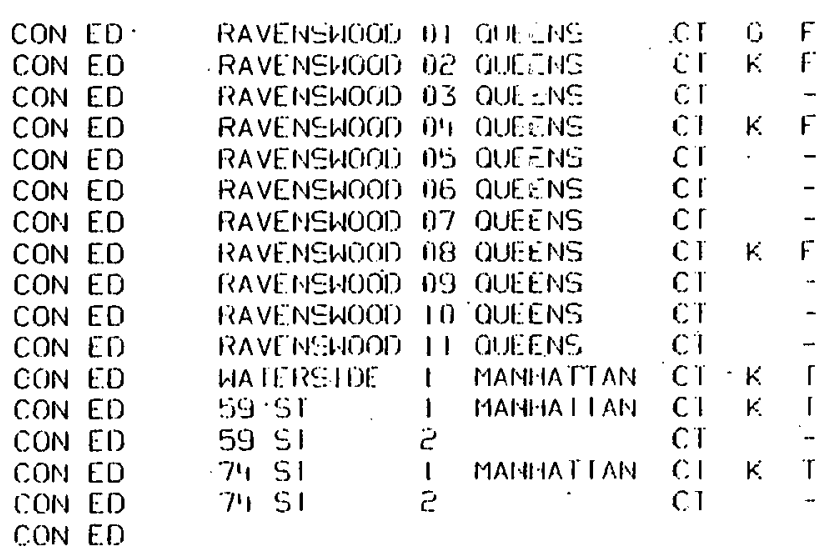

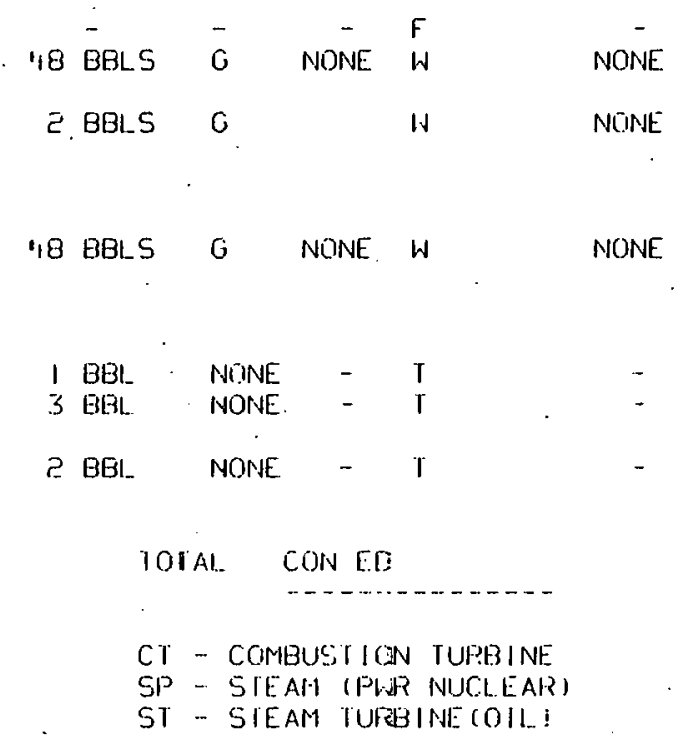

$\begin{array}{rr}0 & 15.857 \\ . & 15.857 \\ - & 15.857 \\ 3911 & 15.857 \\ 198 & 15.857 \\ 306 & 15.85 \% \\ 78 & 15.85 \% \\ 119 & 15.85 \% \\ 127 & 15.857 \\ 911 & 15.857 \\ 135 & 15.857 \\ 104 & 16.177 \\ 118 & 15.457 \\ 130 & 15.155 \\ 71 & 15.583 \\ 128 & 15.583\end{array}$

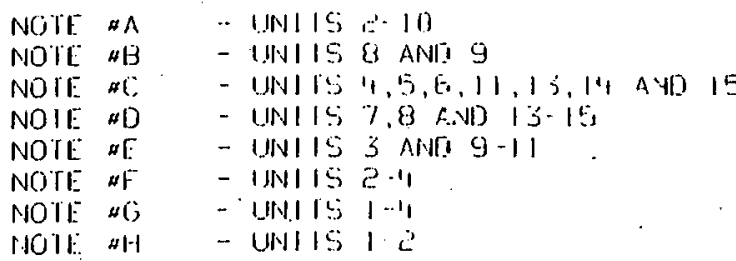


"NYFP(I.11..CO).\%

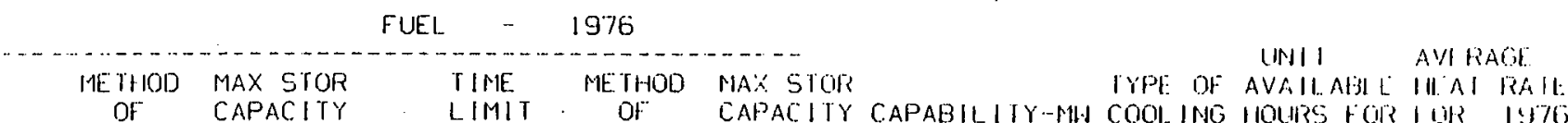

OF CAPACITY LIMIT OF CAPACITY CAPABILITY-MMI COOI.ING IIOUIRS FOIR IGIR IIITE

SIATION INAI LOCATIOIN ITIS PRI HANDLING IX

L.IICO

BARRE TT I ISLANO PA: SI S F

כ ISI.AND FA: 5

E I IAR ROCK SI S

GLENHOOD ? GL ENHOOD SI

SLENWIOOD 3 G. ENWOOD

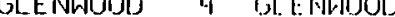

L. ILCO

L ILCO

LIICO

ilitco

iIt.co

LILCO

L. ILCO

LILCO

L. IILCO

1. $11 . \mathrm{CO}$

L. ILCO

L. ILCO

GI.ENHIOOD

I NORTHIPORI SI

NORTHEORT 2 HORTIAOTRI SI

NOR THPORT I HORTHORT 51

POR JEF a

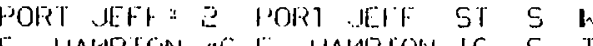

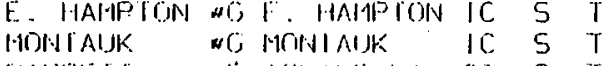

ON USE HANDLLING (X1000) CAPABR ITY-MIN COOH ING WI

970 (B)

m islatiota. cl $S$

Baikrit: I

(C) IS ANII $P A=C$

E IIAMIOION

$S$

IAMPION I E. HANHPlON C:T $S$ T

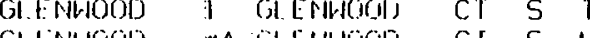

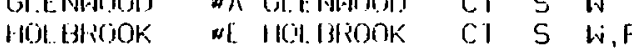

SHORHTHAM I SHOPIIAH COT S T

SOIJTIIOIIO

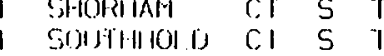

480 BBLS

NONE

\begin{abstract}
…....
\end{abstract}
189

49.6 BBLS $\quad G$ NONE

$49.6 B B L S$
$117.1 \mathrm{BBL}$

NONE

NONE

NONE

NONE

$1988 B 81$

$\begin{array}{lll}W & - & 189 \\ W & \because & 191 \\ W & \therefore & 114\end{array}$

1914
117

$$
77
$$

114
113
386

$115 \mathrm{~A}$

$\begin{array}{ll}77 & A \\ 77 & A\end{array}$

$114 \mathrm{~A}$

$113 \mathrm{~A}$

$386 \quad 386$ A

386 386 A

$-W$

645 BBLS

386 A

1.3 BBLS

1 BBLS

2. 4 BBL 3

11. 4BBL

12 BBL.S

35 B $12 \mathrm{BL}$

1 1 $19 \mathrm{BBL}$

23.8BBL.S

3 BBLS

3 BBLS

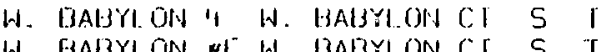

11. 9 BBL.S

L. II.CO

LILCO

$111 \mathrm{CO}$

11 . 9BBLS

TOTAL. LILCO

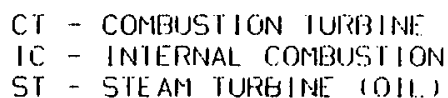

$\begin{array}{rr}1192 & 1455 \\ 13 & 12 \\ 2523 & 25211 \\ -3129 & 3991\end{array}$

\begin{tabular}{|c|c|}
\hline & 31 \\
\hline & 10, ויובוב \\
\hline & $10.9 \%$ \\
\hline 8,78 & $\approx 1$ \\
\hline 8,784 & $* 1$ \\
\hline & 33.11.19 \\
\hline & 10.820 \\
\hline .58 & 10.000 \\
\hline 56 & 9.660 \\
\hline 6 & 9.683 \\
\hline 0 & 13,390 \\
\hline 7.0 & 13.390 \\
\hline 8.136 & 31.336 \\
\hline 501 & 19,335 \\
\hline 3.8911 & \\
\hline 6. & $16.20 \%$ \\
\hline & $16.20 \%$ \\
\hline 8. & 16.030 \\
\hline 8 . & 13,150 \\
\hline 7. & $13.15 \mathrm{E}$ \\
\hline 7,8 & 13.729 \\
\hline 3 & $\because 1$ \\
\hline & 30,33 \\
\hline & \\
\hline & \\
\hline & \\
\hline
\end{tabular}

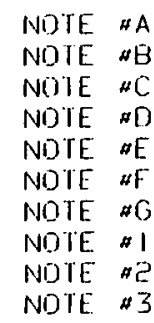

... UNITS 2 ANII.$S$

- APG.

- UNITS 1-8.

- UNITS $9-12$

- UNITS $1-10$

- UNIIS $1-3$.

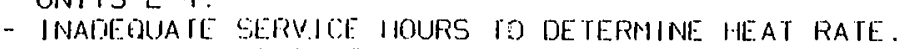

NITE aC -. INCL UDES EXTENSIVE IESTING.

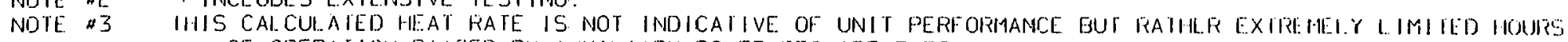
OF OPERATION BIASED BY AJXII. IARY POHER REQUIREMENTS. 
"NYPPINIAGARA MOHIAHKI\%

FUEL.

1976.

UNII AVIRACI

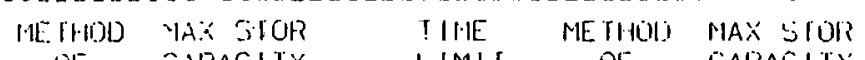

IYPE OI AVAII.ABI.E IIEAI RAII

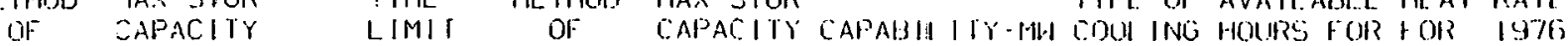

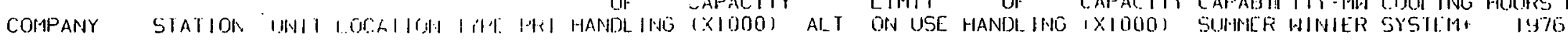
(BrU/KWII)

NIAGARA H: ALBAINY NIAGARA $M *$ ALBANY

NIAGARA M: AL BANY

NIAGARA M* AL BANY

NIAGARA M" DUNKIRK

NIAGARA MO DUNKIRK

NIAGARA M* OUNKK IRK

NIAGARA M" DUNK. IFE:

NIAGARA 11: HUNTLEY

NIAGARA M: HUNIIIF

NIAGARA M: HUNILEY

NIAGARA $M=$ IUNNII EY

NIAGARA M: HUNIII.Y

NIAGARA Ha HUNHIEY

NIAGARA M* OSLII: OO

NIAGARA M: OSWIOGO

NIAGALAA H= OSINI GOS

NIAGatia $M=0$ ostiogo

NIACAARA M: OSINI 60

w NIAGARA Ma ROSI IOIM

\begin{tabular}{|c|c|c|c|c|c|c|}
\hline $\bar{j} E^{-}$ & BBLS & $c$ & - & $W$ & 150 & TONS \\
\hline & & - & - & W & & - \\
\hline & & - & - & $W$ & & - \\
\hline & & - & - & W & & - \\
\hline 35.9 & TONS & - & - & - & & - \\
\hline & & -- & - & - & & - \\
\hline & & - & - & - & & - \\
\hline & & - & - & - & & - \\
\hline $50:$ & TONS & - & - & $T, R, H$ & & - \\
\hline & & - & -. & - & & - \\
\hline & & - & - & - & & - \\
\hline & & - & - & - & & - \\
\hline & & - & - &.- & & - \\
\hline & & - & -. & - & & . \\
\hline 45 & II)BEI.S & - & - & $W$ & & - \\
\hline & & - & - & W & & - \\
\hline & & - & - & $W$ & & .. \\
\hline & & - & - & H & & - \\
\hline & & - & - & $T, R, H$ & & $\cdots$ \\
\hline & 2 & - & - & H & $=$ & $\| 1$ \\
\hline & - & - & - & - & & - \\
\hline & - & -. & - & - & & - \\
\hline . & - & - & - & - & & - \\
\hline & - & - & -. & - & & - \\
\hline & - & - & - & - & & - \\
\hline & - & - & - & - & & - \\
\hline & - & - & $\cdots$ & - & $\vdots$ & 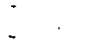 \\
\hline & - & - & - & - & & - \\
\hline 55 & AB .5 & - & - & $r$ & & \\
\hline & & & - & $\mathrm{T}$ & & \\
\hline
\end{tabular}

100

\begin{tabular}{|c|c|}
\hline 1 & BL HA. EHIEM \\
\hline$i$ & $\mathrm{BI}^{-} \| \mathrm{CH}$ \\
\hline & BEE HI: E H II H \\
\hline 1 & $\mathrm{LH}^{-} \mathrm{H}+1 \mathrm{CH}-\mathrm{H}$ \\
\hline 1 & 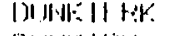 \\
\hline 2 & 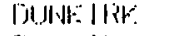 \\
\hline 3 & [ju怗: IKK \\
\hline '1 & LJHNEIIKK \\
\hline 6. & IONABHAINIA \\
\hline $6 ; 4$ & HOHJA:HAHIBA \\
\hline 56 & TOMALHALIIIA \\
\hline $65 j$ & IONA:IANIIA \\
\hline (ii) & WWNAHAMUIA \\
\hline rits & I(UIALUANHI) \\
\hline 1 & (15; \\
\hline$i^{\prime}$ & (1).atat 0 \\
\hline & (i!stilo \\
\hline 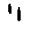 & (j)洲 6, o \\
\hline$\therefore$ & of \\
\hline ai & 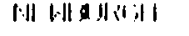 \\
\hline & $\mid 11 \cdot \because \cdots$ \\
\hline & $\therefore|A||| I \mid W$, \\
\hline & \\
\hline & \\
\hline & \\
\hline
\end{tabular}

I Bt

la lat IHA LIIIM CI K F

IS Bi la H H IIM CF $K F$

li III H IIIIM CI K F

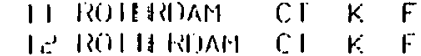

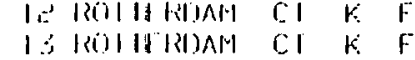

Ii ROIIIRIMAM B. $\mathrm{k} F$

13 RCil H WIBAM Cl K

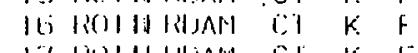

$1 \%$ RuIII WIAM 2 l $k$

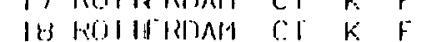

NJAGAFA MA ROITLRIDAR

NIAGARA $M *$ ROIIITHIJAN

NIAGARA M" ROIILIRLIAM

NIAGARA I: $^{\circ}$

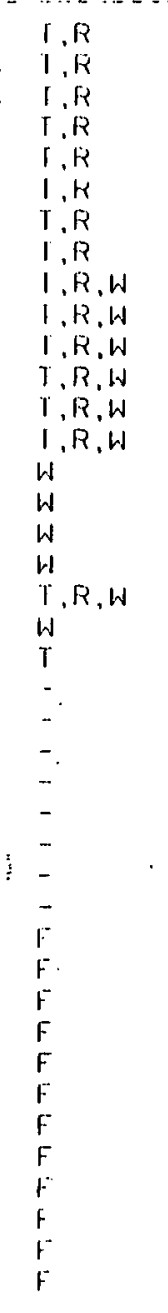

35.25

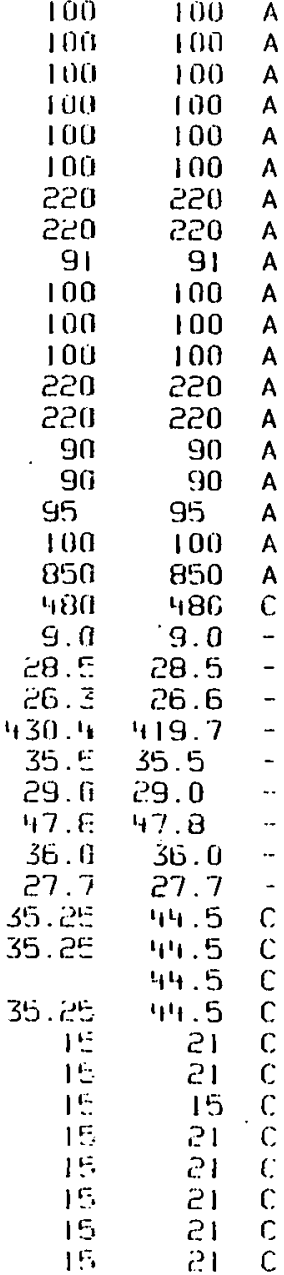

$\begin{array}{rr}8.081 & 10.3613 \\ 7.673 & 10.339 \\ 8.291 & 10.320 \\ 8.273 & 10.321 \\ 6.181 & 10.316 \\ 6.586 & 10.339 \\ 7.393 & 9.976 \\ 7.707 & 9.605 \\ 5.951 & 11.943 \\ 11.951 & 11.035 \\ 6.092 & 10.423 \\ 6.667 & 10.274 \\ 6.074 & 9.839 \\ 8.261 & 9.951 \\ 7.120 & 12.345 \\ 7.8118 & 12.420 \\ 7.763 & 12.255 \\ 7.061 & 11.091 \\ 3.088 & 10.195\end{array}$

$8.4 \% \cdot 15,056$

$8,699 \quad 15.056$

$8.738 \quad 15,056$

$0.178 \quad 15.056$

8. 16.050

8.783 16,050

8.780 16.050

$8.779 \quad 16,050$

8.158

8.683

8.6 .08

TOTAL INIAGARA MOHALIK

CI - COHBJISTION RUREINE 


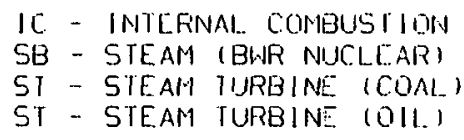

$\begin{array}{rr}9 & 9 \\ 610 & E 10 \\ 11 \% 1 & 11 \% 1 \\ 2105 & 2109 \\ 311 \% & 5192\end{array}$

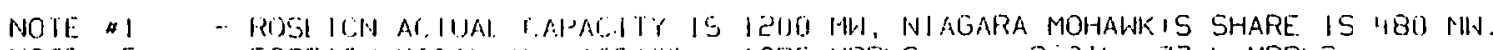

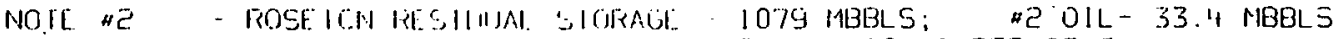

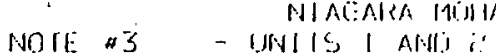

AYHP (NYSTE +G)\%

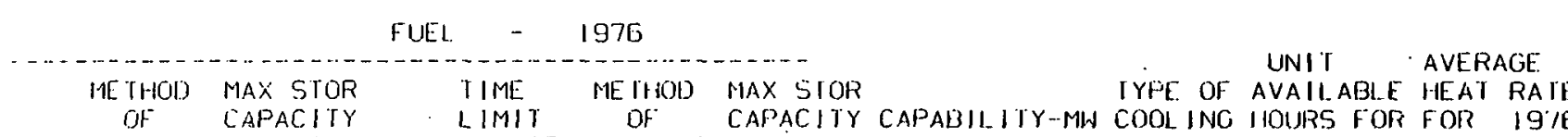

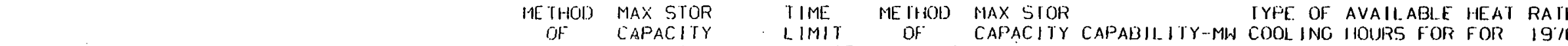

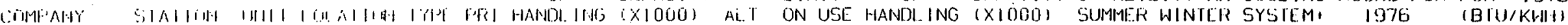

(........

Nosto

NARE $M$

Ná $N E$

NÁSE 10

NISE,

NiSE. 16

NiSt. 10

NASE 10

N.YSE +

Ni'SE $1 \mathrm{Ni}$

NISE 16

Nrist 10

NTSE. 16

Wist i. Co

NASE $+C$

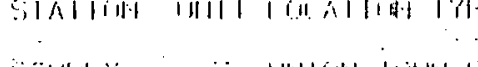

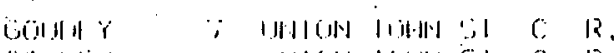

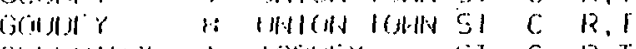

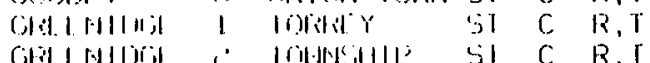

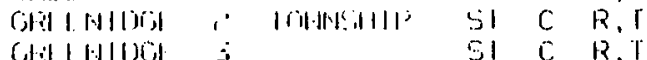

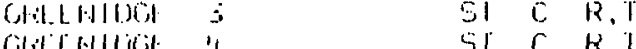

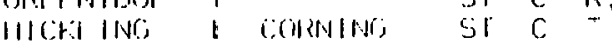

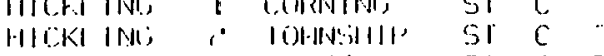

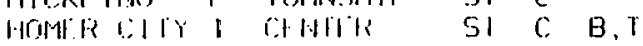

icille olly lom

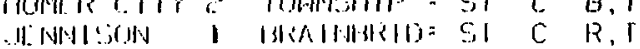

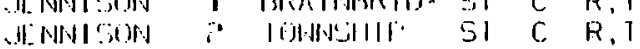

MIIIIKAN I IAMUING SI C R,

HIIIIKEH $\because$ liHNSIII, S! C R,T

$19 . .$.

BIU/KHII

MISB.

125 TONS

300 IONS

Misi: Hor

III -

70 TONS

$125010 *$

I00 TOMS

250 TONS

$-$

TOTAL NYSE T!O

IC - INIERINAL COMBUSIION

ST - STEAM TURBINE ICOAI

$\begin{array}{rr}13 & 13 \\ 1577 & 1377 \\ 13911 & 1390\end{array}$

$7.751 \quad 12.704$

$8.090 \quad 10.128$

$7.797 \quad 14.513$

$6.451 \quad 15.271$

$8.051 \quad 12.633$

$5.108 \quad 10.771$

$8.713 \quad 15.657$

$8.780 \quad 1 \% .860$

$1,36119.516$

$6.651 \quad 10.351$

$7.938 \quad 16.2 .6 \mathrm{E}$

$8.769-15.817$

$8.217 \quad 9.516$

Nist 
\#NYPPIORAINOLE HROCKL.A.ANO I\%

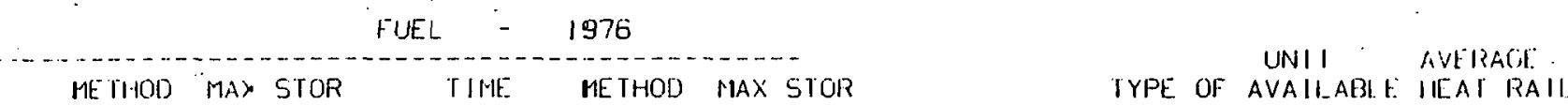

ME THOD MAX STOR TIME METHOD MAX STOR TYPE OF AVAIIABIL IIEAT RAIL

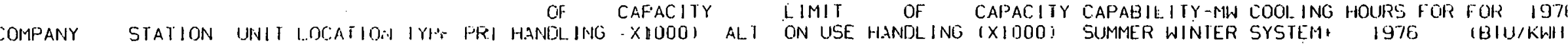

\begin{tabular}{|c|}
\hline 5 \\
\hline
\end{tabular}

ORANGE + RO * BOWL INE

GRANGE + RO* BOHNL INE

ORANGE +RO * LOVE. I

DRANGE +RO" LOVET T

ORANGE+RO: LOVE I I

ORANGE, +RO: LOVE II

ORANGE +RO" HYORO

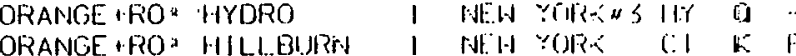

1 MII $W^{2}$ Oli

HEW $\sim$ OHQ⿻

I.EW $\sim$ ORPC:

E NEW OOR०

$\because \quad S \quad W$

$\begin{array}{ccc}201 & 201.1 & A \\ 200 & 20011 & A \\ 19 & 19 & A \\ 20 & 20 & A \\ 63 & 63 & A \\ 197 & 197 & A \\ 202 & 202 & A \\ 14 & 111 & - \\ 37 & 113 & C \\ 37 & 43 & C\end{array}$

$4.952 \quad 9.73$

21. BBLS

$-\quad-\quad W$

放 5 a

4 Nin ville il ce

5 NWWOI?k SI 5 स4

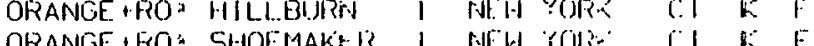

ORANGE + RO=

5.1 BBLS

G.C NONE $72 \mathrm{H} \quad 75$ HONS

75 TONS

G.C NONE

h

a A

$6.173 \quad 9.651$

G.C NONE

$H$

G.C NONE

h

NONE $i=$

$\begin{array}{ll}8.751 & 21.318 .5 \\ 8.727 & 19.91 \%+13\end{array}$

$\begin{array}{ll}7.158 & 13.817\end{array}$

$7.598 \quad 10.47 \mathrm{C}$

$8.595 \cdot 10.720$

TOTAL ORANGE +ROCKL.ANH)

CT - CONVENTIOA- TURBINE

HY - CONVENTIONAL HYORO

ST - SIEAM RURBINE (OII.)

\begin{tabular}{rr}
$\% 4$ & 86 \\
144 & 44 \\
902 & 902 \\
\hline 1020 & 1032
\end{tabular}

NOIE $\#$

NOIE "I

NOTE "2

NOIL $\# 3$

NOIE W.

NOIE $\because 5$

NOIE $\triangle G$

NOIE $y^{-}$

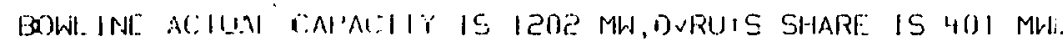

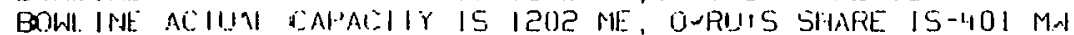

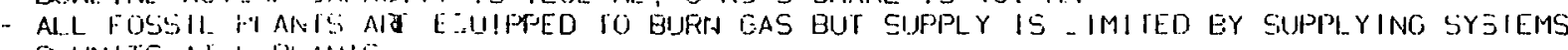
- $g$ UNTTS AT 'P PI. ANIS.

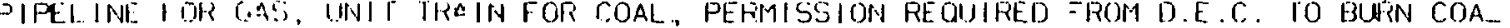

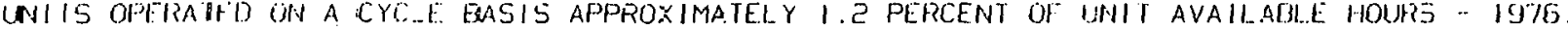

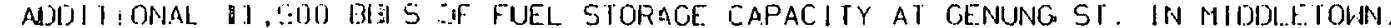

- BOWL WHE RESTJUA STCRAGE CAFACITY IJ B?G MBBLS. OVRU SHARE OF IHIS IS I/3. 
-NYPP(PASNY)\%

FUEL - 1976

UNIIT

AVERAGE.

METHOD MAX STOR TIME METHOO MIAX SIOR

TYPE OF AVAILABLE HEAT RATE CAPACITY LIMIT OF CAPACITY CAPABIL.IIY-MW COOL.ING HOURS FOR FOR I976

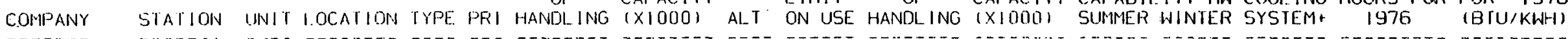
PASNY $10,708 * 1$ PASNY

PASINY INDIAN FO: 3 BUCHANAN FI [ZLPATRI: SCRIBA

Al.JX. PUMP"

N. $Y$

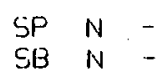

BLFNHIFM "

a Gill BOA

MOSES NIA. NIAG FALISS HY O -

MOSES POW' MESSENA HY O -

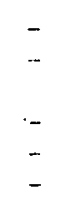

TOIAI

\begin{tabular}{rr}
873 & 873 \\
770 & 770 \\
1000 & 1000 \\
2400 & 2400 \\
800 & 800 \\
& \\
3000 & 3200 \\
1000 & 1000 \\
770 & 770 \\
873 & 873 \\
\hdashline 5813 & 58313
\end{tabular}

NOTE HA - INNIL $1 \ldots 1$

FROM SIARI OF COMMIIRCIAL. OPERATION 8/30/76. 
NYPP $(R G+E) \%$

\section{$\begin{array}{cccc} & \text { FUEL } & & 976 \\ \text { METHOD MAX STOR } & \text { TIME } & \text { METHOD MAX STOR } \\ \text { OF } & \text { CAFACITY } & \text { LIMIT } & \text { OF } \\ \text { LAPACITY }\end{array}$

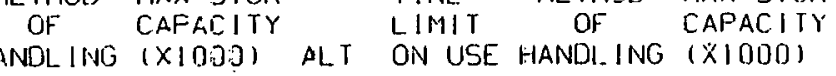

COMPANY

RG+E

$R G+E$

$R G+E$

RG+E

$R G+E$

$R G+E$

$R G+E$
$R G+E$

$R G+E$

$R C+E$

$R G+E$

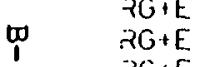

$2 G+E$
$2 G+E$

ROG I.E

$\mathrm{RC}, \mathrm{E}$

$\mathrm{RG}+\mathrm{E}$

$B G+E$

RGIE
. $A L T \quad O N$

BEEBEE la ROC-IESIER כl

BEEBEE

4) ROC-ALSIER

1 GREECL

GRTECL

RUSSELL

RUSSEL..L

STA B

STA. 8

GINNA

MISC. "C

SIA.

STA.

STA is

SiA.

SIA. S

BI:EBEE

GREECE

CREECE

I ROCHESIIER

ROCHESTER

ONIARIO

IIr 0

ROAHESILR HY a

ROCIIESTER IY O

1 ROCHESIEL HO O

c rocyilster wir a

- rochifsilir hy a -

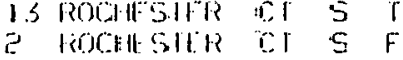

EO TONS

EI B3LS

NDNE

NONE - -

EQU TONS

\section{NONE}

NONE

NDNE

NONE

-

NONE

$19 \mathrm{BBL}$

21
-
-

$\begin{array}{cc}1.8 \text { BHI.S NONE } & - \\ - & \text { NONE }\end{array}$
UNIT

AVERAGE

IYFE OF AVAILABLE IIEAT RAIE CAPAB I IIY-MU COOL ING HOURS FOR FOR 1976 SUMMLR WINIER SYSTEM+

$19 \% 6$ (BIU/K.WI-1)

80
112
50
65
65
80
0
19
470
0
6
2
17
11
11
14
13

$\begin{array}{rr}80 & A \\ 93 & A \\ 50 & A \\ 65 & A \\ 65 & A \\ 80 & A \\ 3 & A \\ 3 & A \\ 170 & A \\ 1 & - \\ 5 & - \\ 2 & - \\ 17 & - \\ 12 & - \\ 11 & - \\ 18 & C \\ 18 & C\end{array}$

$8.190 \quad 9.900$

$7.1166 \quad 11.500$

$7.317 \quad 10.240$

$7.354 \quad 10.235$

$8.002 \quad 10.090$

3

43

$5.115 \quad 11.570$

$-$

$-$

TO-AL $\quad$ RGHE

CT - COMBUSIION TUFBIINE

HY - CONVENTIONAL. HYDRO

SP - STEAM (PIR NUCLEAP)

ST - SIFAM TUROBINE (COG1)

ST - SIEAM TUFBINE 101!.)

NOTE $\quad$ COMMÖN itt:AlJ:K I-61S NOMS. 1,2,3,6,3,9,10,11.

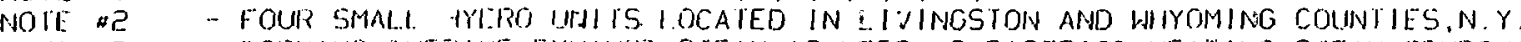

NOIE "3 $\because$ IOPNING IUREINE EXHAUSI STEAM 15 USED AS DISIRICI HEATING SIEAM SENDOUI

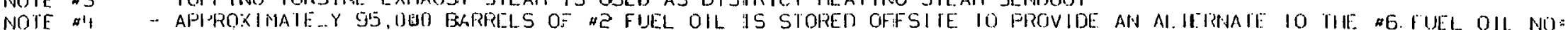


"NYPP(CITY OF JAMESTOWINI:

FUEL
IMETHOD MAX STOR
OF CAPACITY
$\begin{array}{llll}\text { I.TE THOD MAX STOR } & \text { TIME } & \text { METHOD MAX STOR } \\ \text { OF } & \text { CAPACITY } & \text { LIMIT } & \text { OF } \\ \text { CAPACIIY }\end{array}$

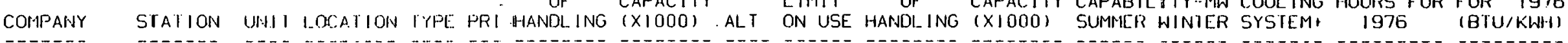
CITY OF J" S.A. CARL \& JAAESTOWN CITY OF J: S.A. CARI: 3

CITY OF J: S.A. CARL" i

CITY OF JA S.A. CARI :

CITY of $J$ : S.A. CARI :

$\underset{\omega}{\infty}$

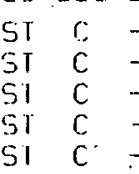

$\begin{array}{ll}- & \\ - & \\ - & \\ - & \end{array}$

-
-
-
-

TOTAL

$\begin{array}{cc}- & - \\ - & - \\ - & - \\ - & -\end{array}$

CITY OF JAMESTOWN

ST - STEAM TURBINE (COAL)

$\begin{array}{rrr}5 & 5 & - \\ 15 & 15 & - \\ 13 & 13 & - \\ 20 & 20 & - \\ 25 & 25 & -\end{array}$

$-$

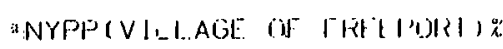

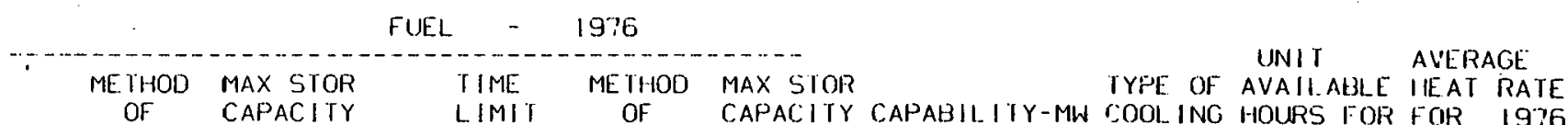

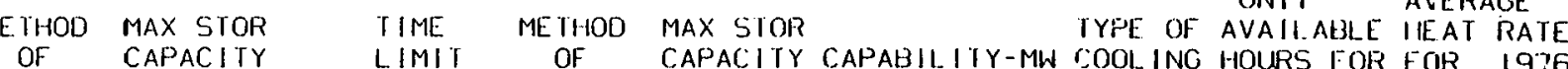

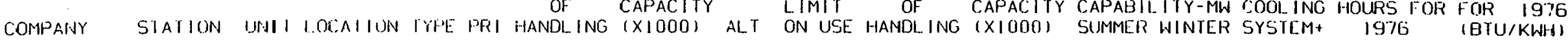

VILLAGE O* BUFFALO A: I FHLEFOIRI

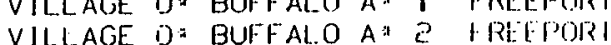
VILLAGE O: SUNRISE $11:$ II) FRELPORI VILLAGE D: SUNRISE $1^{*}$ I1) FRELPORI VILLAGE $0^{*}$ SUNRISE H* II FRIEPORI VILLAGE $D *$ SUNRISE H: 9 FREEPOR VILLAGE 0 : BUFFAI O A* 3 FREEPOR

IC
IC
IC
IC
IC
IC
CT

-1
-
-
-
-
-
-

$\begin{array}{cc}38 \text { BBLS } & - \\ - & - \\ - & - \\ - & - \\ 4.8 \text { BBLSS } & -\end{array}$

TOTAL

VILLAGE GF FREEPORT

$\begin{array}{rr}78 & 78 \\ -7 . & --- \\ -78 & 78\end{array}$

IC - INTERNAL COMBUSTION

$\begin{array}{rr} & \\ & \\ 12 & \\ 12 & 12 \\ 11 & 21 \\ 32 & 32 \\ 32 & 32\end{array}$


aNYPPICITY OF PLATISB̈IJRGHA:

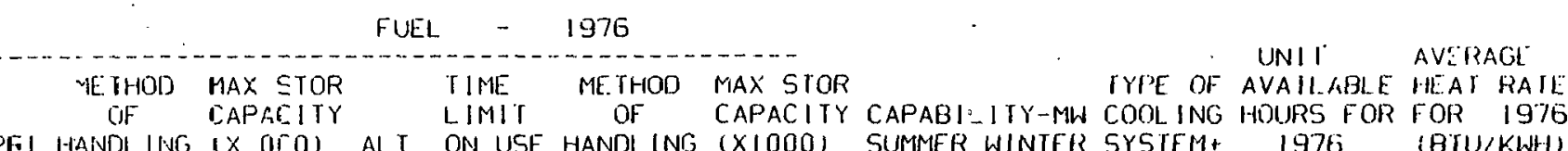

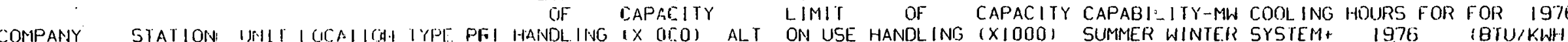

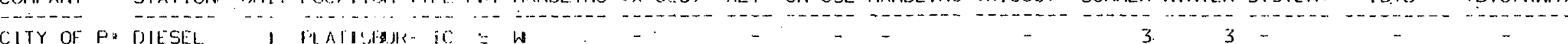

TOTAL CITY OF PLATTSBUIRGH

IC - INTERNAL COMBUSTION

$\begin{array}{rr}3 & 3 \\ 3 & 3\end{array}$

ALIPIPEI INESG SOASI\%

\section{INAS SIJPHLY FROM ALL. PIPEH INES TO THE SIAIE 1976}

PIPEL.INE

(J.IAH) IIY

$\mathrm{COS}$
D/MCF

ALGONOUIN NAI

ALGONOUIN SYN

ASH HI_AND SYN

BOROEERILINF:

COL UMBIIA NAI

COLUMBIIA SYM

CONSOT. HIIATLD

DISTRI CIAS

NATTIONAL.

TENMESSEE

TEXAS EASTERN

TRANS CANADA

TRANSCONIIMENIAL

\begin{tabular}{|c|c|}
\hline Mit: & D/MCF \\
\hline 1. , $, 11 \%, 132$ & $\begin{array}{l}41.8 \% \\
95.25\end{array}$ \\
\hline 1), (30is), 1)(1) & 93.26 \\
\hline 16.878 & $\pm 1.4 \mathrm{~L}$ \\
\hline $3 \therefore, 640,(510)$ & $\$ 1.201$ \\
\hline 6137,088 & $\$ 4.3 \%$ \\
\hline $181,715,1988$ & $\$ 1.17$ \\
\hline$-183,211$ & $\Phi 2.17$ \\
\hline $14 r^{2} .639 .005$ & $\$ 1.20$ \\
\hline & $\$ 1.08$ \\
\hline $30,830,150$ & $\$ 1.33$ \\
\hline $5.536,103$ & $\$ 1.77$ \\
\hline $166,6 \geq 1,863$ & $\$ 1.09$ \\
\hline $63: .667,564$ & $\$ 1.221$ \\
\hline
\end{tabular}

$63: .637,564$

1.221 


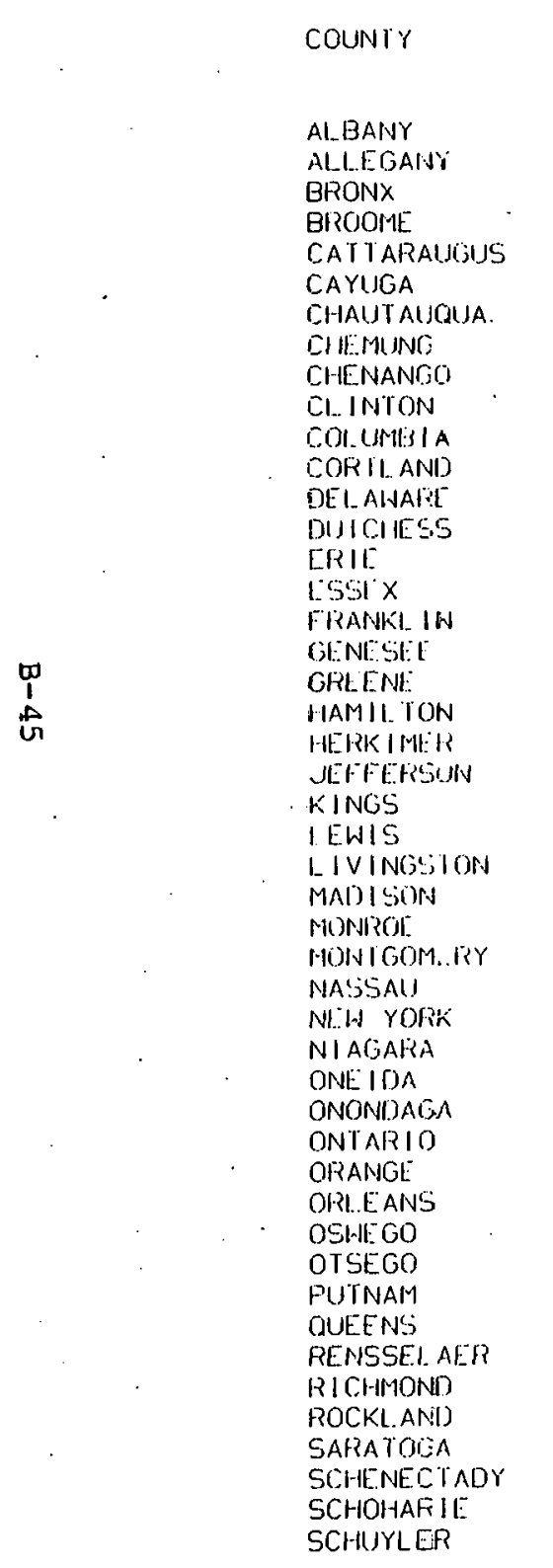

\begin{tabular}{|c|c|c|}
\hline $\begin{array}{l}\text { RE SIOENIIAL } \\
\text { BIUSIXIE09I }\end{array}$ & $\begin{array}{l}\text { COMMERCIAL } \\
\text { BTUSIXIEOS }\end{array}$ & $\begin{array}{l}\text { AUTOS } \\
\text { BIUS(XIEOS): }\end{array}$ \\
\hline 8.052 & 6.721 & $\mid 2, \pi 11$ \\
\hline $1,60.0$ & 228 & $2,1+79$ \\
\hline 10,056 & 28,003 & 16.710 \\
\hline 3.950 & 1.187 & 11.587 \\
\hline 1.206 & 1.312 & 1,222 \\
\hline 1.685 & 1.601 & 1,084 \\
\hline 1.059 & 468 & 7,892 \\
\hline $81^{1} 1$ & 391 & 4.810 \\
\hline 2.395 & 1.392 & 2.690 \\
\hline $4,1,184$ & 2.740 & 3.785 \\
\hline 2.647 & 1,421 & 3.348 \\
\hline 1.020 & 1.033 & $2,451.1$ \\
\hline 2.439 & 1.371 & 2.721 \\
\hline 10.841 & 6.205 & 3.415 \\
\hline 5,947 & 2,907 & 35.031 \\
\hline 2.641 & 1,282 & 2.039 \\
\hline 3.112 & 1.532 & $2,16^{4}$ \\
\hline 1.257 & 1.211 & 3.415 \\
\hline 2.174 & 1,005 & 1.323 \\
\hline 393 & 169 & 353 \\
\hline 2.678 & 1,947 & ᄅ, 996 \\
\hline 3.211 & 2,315 & 3.835 \\
\hline 64.804 & 48,746 & 41.839 \\
\hline 1.591 & 825 & 1.323 \\
\hline 1.434 & 1,284 & 2.698 \\
\hline 2.160 & 1.732 & 3,246 \\
\hline 12,812 & 13,596 & 31,121 \\
\hline 1.537 & 1.172 & 2,760 \\
\hline 59.946 & 31,798 & $.73,463$ \\
\hline 48.313 & 44,005 & 13,327 \\
\hline 7.277 & 5,511 & 8,433 \\
\hline 8,063 & 7,289 & 11,652 \\
\hline 4.559 & 2.311 & 23.885 \\
\hline 1.833 & 1.776 & 4.189 \\
\hline 8.090 & 5,826 & 12,551 \\
\hline 1.379 & 947 & 1,941 \\
\hline 2.676 & 2.379 & 5.460 \\
\hline 2.984 & 1.743 & 3,081 \\
\hline 3.919 & 1.817 & 3,248 \\
\hline 60.733 & 39,907 & 44.238 \\
\hline 5,153 & 3.643 & 6.909 \\
\hline 7,743 & 5.933 & 9.654 \\
\hline 1.208 & 630 & 10.203 \\
\hline 4.622 & 3.326 & 7.587 \\
\hline 4.525 & 3.553 & 8,197 \\
\hline 1.667 & 854 & 1.611 \\
\hline 579 & 422 & 1.050 \\
\hline
\end{tabular}

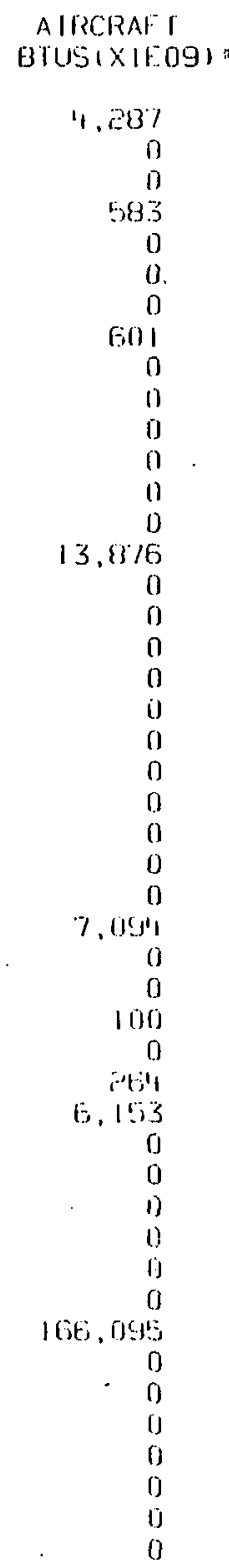

rOTALS BTUSIX1E091

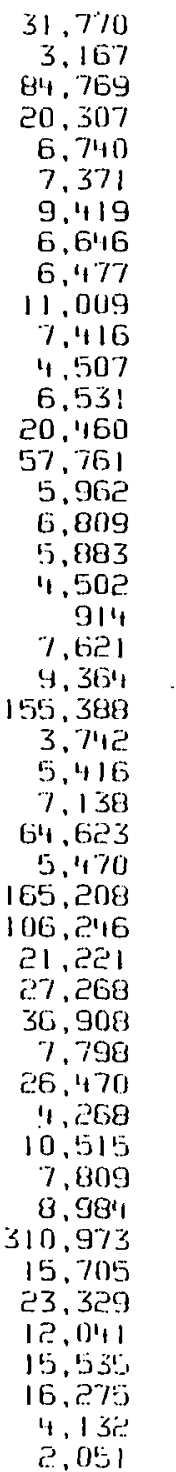




\begin{tabular}{|c|c|c|c|c|c|}
\hline $\begin{array}{l}\text { SENEC.A } \\
\text { STEUEEN } \\
\text { ST. LAWRENCE } \\
\text { SUFFOLK } \\
\text { SULLIVAN } \\
\text { TIOGA } \\
\text { TOMPKINS } \\
\text { ULSTER } \\
\text { WARREN } \\
\text { WASHINGION } \\
\text { WAYNE } \\
\text { WESTCHESTER } \\
\text { WYOMING } \\
\text { YATES }\end{array}$ & $\begin{array}{r}770 \\
1,8+2 \\
5,499 \\
46,7+4 \\
4,078 \\
2,1.27 \\
1.405 \\
7,697 \\
2,434 \\
2, .13 \\
2.449 \\
29.841 \\
.678 \\
.665\end{array}$ & $\begin{array}{r}719 \\
1.793 \\
3.765 \\
26.580 \\
1.969 \\
1.345 \\
1.655 \\
4.038 \\
1.713 \\
1.358 \\
1.911 \\
19.011 \\
716 \\
504\end{array}$ & $\begin{array}{r}1.947 \\
5.441 \\
5.578 \\
53.793 \\
3.970 \\
2.782 \\
3.963 \\
8.522 \\
2.980 \\
2.796 \\
4.318 \\
34.517 \\
2.212 \\
1.346\end{array}$ & $\begin{array}{r}0 \\
0 \\
0 \\
320 \\
0 \\
0 \\
+83 \\
0 \\
0 \\
0 \\
0 \\
260 \\
0 \\
0\end{array}$ & $\begin{array}{r}3.136 \\
9.076 \\
14.841 \\
127.937 \\
10.017 \\
6.253 \\
7.507 \\
20.457 \\
7.127 \\
6.367 \\
8.679 \\
82.929 \\
3.606 \\
2.515\end{array}$ \\
\hline TOTALS & 530,104 & 367.546 & 602.400 & 200.616 & 1.700 .665 \\
\hline
\end{tabular}

- modor gasol ine demand for autios

- JET fUEL DEMAND fOR PASSENGER AND fPEIIJHT aIRC:raft

\begin{tabular}{|c|c|c|c|c|c|}
\hline UTILITY & $\begin{array}{l}\text { RESICENTIAL } \\
\text { BIUS(KIEOS) }\end{array}$ & $\begin{array}{l}\text { COMMERCIAL } \\
\text { BTUS (XIEOS) }\end{array}$ & $\begin{array}{l}\text { AUTOS } \\
\text { BTUS(XIEOS) }\end{array}$ & $\begin{array}{l}\text { AIRCRAFT } \\
\text { BTUSIXIE09).. }\end{array}$ & $\begin{array}{c}\text { TOTALS } \\
\text { BTUSIXIEOS) }\end{array}$ \\
\hline $\begin{array}{l}\text { CENTRAL HWDSON } \\
\text { CON ED } \\
\text { LILCG } \\
\text { NIAGARA MOHIAWK } \\
\text { NYSE+G } \\
\text { ORANGE+ROCKLAND } \\
\text { RG+E }\end{array}$ & $\begin{array}{r}24.830 \\
250.790 \\
106.591 \\
90.908 \\
30.434 \\
9.297 \\
17.094\end{array}$ & $\begin{array}{r}13,066 \\
185,606 \\
5 E, 379 \\
6, .703 \\
23,053 \\
E, 450 \\
17,283\end{array}$ & $\begin{array}{r}16.508 \\
160.784 \\
127.255 \\
175.358 \\
60.108 \\
22.758 \\
39.629\end{array}$ & $\begin{array}{r}0 \\
166.455 \\
820 \\
24.580 \\
1.667 \\
0 \\
7.094\end{array}$ & $\begin{array}{r}54.404 \\
763.635 \\
293.145 \\
354.549 \\
115.321 \\
38.511 \\
81.100\end{array}$ \\
\hline TOTALS & 530,104 & $36 \pi .546$ & 602.400 & 200.616 & 1.700 .665 \\
\hline
\end{tabular}

- motor gasol ine demand for autos

- Jet fuel deimand for passenger and freight aircraft 
-OILCOUNTY (SUFFOLK):

UTILITY
LILCO

OII. DEMAND FOR COUNTY

RESIDENT I AL

BTUS ( $X I E 09)$

$46,74 \mathrm{~L}$

COMMERCIAL
BTUS (XIEO9)

BTUSIXIE
26,580
AUTOS
BTUS $(X \mid E 09)$
53,793

AIRCRAFT

BTUS (XIE09)"

820

TOTALS

BTUSIXIEOO

127,937
* Ollutility(CEntral huDSON)x

O.L DEMAND FOR UTILITY

\begin{abstract}
COUNTY
\end{abstract}
RESIDENTIAL

COMMERC IAL
BTUS (XIEOS)

$$
\begin{array}{r}
10.841 \\
2.174 \\
3.919
\end{array}
$$

3.919
7.897

24.830

GREENE

ULSTER

TOTALS

- motor gasol ine for autos

* JET FUEL DEMAND FOR PASSENGER AND FREIGHT AIRCRAFT

\section{CENTRAL HUOSON}

$$
\begin{gathered}
\text { AUTOS } \\
\text { BTUS (XIE09). }
\end{gathered}
$$

$$
\begin{aligned}
& 3.415 \\
& 1.323 \\
& 3.248
\end{aligned}
$$$$
1.005
$$$$
\begin{aligned}
& 1.817 \\
& 4.038
\end{aligned}
$$

13,066
1976

AIRCRAFT
QTUS $(X \mid E 09) *$

0
0

0

0

0
TOTALS BTUS(XIE09)

\subsection{0}

4.502

8.984

20.457

54.404

\section{*OILUTILITYICON EDI\%}

COUNTY.

BRONX
KINGS
NEW YORK
QUEENS
RICHMOND
WESTCHESTER

TOTALS
OIL DEMAND FOR UTILITY

RESIDENTIAL
BTUS (XIEO9)
40,056
64,804
48,313
60,733
7,743
29,141
250,750

\section{COMMERCIAL,}

28,003

48.746

44.005

39.907

5,933
19,011

185,606

\section{CON ED}

AUTOS
BTUS (XIE09):
16,710
41,839
13,827
44,238
9.654
34,517
160,784

1976

AIRCRAF T

BTUS (XIE09) *:

0
0
100
166,095
0
260
166,455

TOTALS BTUS (XIEOO)

$$
\begin{array}{r}
84.769 \\
155.388 \\
106.246 \\
310.973 \\
23.329 \\
82.929 \\
763.635
\end{array}
$$

- motor gasol ine for autos

" JET FUEL DEMAND FOR PASSENCER AND FREIGHT AIRCRAFT 
-oilutilityil ilcoiz

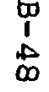

QIL CEMAND FGF UTILITY

\begin{tabular}{|c|c|c|}
\hline $\begin{array}{l}\text { RES I DENT I AL } \\
\text { ETUSIXIEJ9) }\end{array}$ & $\begin{array}{l}\text { COMMERCIAL } \\
\text { BTUS (XIE09) }\end{array}$ & $\begin{array}{c}\text { AUTOS } \\
\text { BTUS!X(E09) * }\end{array}$ \\
\hline $\begin{array}{l}59.946 \\
46.744\end{array}$ & $\begin{array}{l}31,798 \\
26,580\end{array}$ & $\begin{array}{l}73.463 \\
53.793\end{array}$ \\
\hline 106.691 & $58 \quad 379$ & 127.255 \\
\hline
\end{tabular}

1976

AIRCRAFT TOTALS BTUS(XIE09) $\cdots \quad$ BTUS(XIE09)

0

820

165.208

127.937

- motor gasol ine fCr auios

" JET FUEL DEMAVD fOR PASSENGER AND FFEIGHT AIRCRAFT 
- OILUTILITY(NIAGARA MOHAWK) $z$

CIL DEMANO FOR UTILITY NIAGARA MOHAWK

COUNTY

\section{ALBANY}

CATTARAUGUS

CHAUTAUQUA

CLINTON

COLUMBIA

CORTLAND

ERIE

ESSEX

FRANKL IN

HAMILTON

HERKIMER

JEFFERSON

LEWIS

MONTGOMEFY

NI AGARA

ONE IDA

ONONDAGA

ORLEANS

OSWEGO

RENSSELAER

SARATOGA

SCHENECTADY

SCHOHARIE

ST. LAWFIENCE

WARREN

WASHINGTON

TOTALS

RESIDENTIAL

COMMERCIAL

BTUS (XIE09)

8. 052

1.2016 .

1.059

4.484

2.647

1.020
5.947

2.641

3.112

1.257
393

393
2.678

3.2:4

1.591

1.537

7.27

4.559

1.379

2,676

5,153

4,622

4.525

5.479

2, 434

2.434
2.213

6.721
1.312

468
2.740

1.421

1.033

1.282

1.532

1.211

169
1,947

2.315

825

1,172

5.511

2.311

947

2. 379

3,643

3,326
3,553

854

3.765

1.713

90,908

63.703
AUTOS

BTUS (XIE09)

12.711

4. 222

3,785

3. 348

2.454

35,031
2,039

2. 164

3,415

353
2,996

3.835

1.323

2. 760

8.433

11,652

23,885

1,941
5,460

5.460
6.909

7,587

8.197

1.611

5.578

ᄅ. 980

75.358
1976

A IRCRAF T GTUS (XIE09) *.

4.287

0
0
0
0

13.876
0

0
0
0

0

0
0

- 0

0
0

264
6.153

.153
0

0
0
0

0
0

0

0

0

24.580

TOTALS

BTUS(XIE09)

31.770

6.740

9.419

7,416

4.507

57.761

5.962

6.809
5.883

914

7,621

9,364

3.742

5.470

21.221

27.268

36.908

4. 268

10.515

15.705

15,535

16.275

4,132

14,841

7,127

6,367

354.549

- motor gasol ine for autos

* JET FUEL DEMAND FOR PASSENGER. AND FRE IGHT aIRCRAFT 
- DILUT IL ITY(NYSE+C)

OIL DEMAND FOF UTILITY NYSE+G

\begin{tabular}{|c|c|c|c|}
\hline COUNTY & $\begin{array}{l}\text { RESIDENTIAL } \\
\text { BTUS (XIE09) }\end{array}$ & $\begin{array}{l}\text { COMMEREIAL } \\
\text { BIUS(XIE09) }\end{array}$ & $\begin{array}{l}\text { AUTOS } \\
\text { BTUS (XIE09)* }\end{array}$ \\
\hline $\begin{array}{l}\text { ALLEGANY } \\
\text { BROOME } \\
\text { CAYUGA } \\
\text { CHEMUNIS } \\
\text { CHENANISO } \\
\text { OELAWARE } \\
\text { LIVINGSTON } \\
\text { MADISON } \\
\text { OTSEGO } \\
\text { SCHUYLER } \\
\text { SENECA } \\
\text { STEUBEN } \\
\text { SULLIVAN } \\
\text { TIOGA } \\
\text { TOMPKINS } \\
\text { WYOMING } \\
\text { YATES }\end{array}$ & $\begin{array}{r}460 \\
3.950 \\
1.685 \\
844 \\
2.395 \\
2.439 \\
1.434 \\
2.160 \\
2.984 \\
579 \\
770 \\
1.842 \\
4.078 \\
2.127 \\
1.405 \\
678 \\
665\end{array}$ & $\begin{array}{r}228 \\
4.187 \\
1.601 \\
1.391 \\
1.392 \\
1.371 \\
1.284 \\
1.732 \\
1.743 \\
422 \\
719 \\
1.793 \\
1.969 \\
1.31+5 \\
1.655 \\
716 \\
504\end{array}$ & $\begin{array}{r}2.479 \\
11.587 \\
4.084 \\
4.810 \\
2.690 \\
2.721 \\
2.698 \\
3.246 \\
3.081 \\
1.050 \\
1.947 \\
5.441 \\
3.970 \\
2.782 \\
3.963 \\
2.212 \\
1.346\end{array}$ \\
\hline TOTALS & 30.4911 & 23.053 & 60.108 \\
\hline
\end{tabular}

- motcr gasol ine jof autes

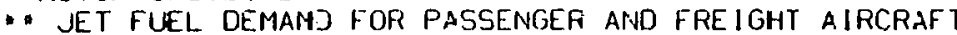

1976

AIRCRAFT

BTUS (XIE09) * *

TOTALS BTUS (XIE09)

0
583
0
601
0
0
0
0
0
0
0
0
0
0
483
0
0
1.667

3,167
20.307

7.371

6.6146

6.477

6.531
5.416

7.138

7.809

2.051

3,436

9.076

10.017

6.253

6.253

7.507
3.606

2. 515

1.667

$|15.32|$

"OILUTILITYIORANGE +F:OCKL ANDI\%

OIL DEMAND FOR UTILITY ORANGE+ROCKLAND

1976

$\begin{array}{lccc}\text { COUNTY } & \begin{array}{c}\text { RESIDENTIAL } \\ \text { BTUS(XIE09) }\end{array} & \begin{array}{c}\text { COMMERCIAL } \\ \text { BTUS(XIE09) }\end{array} & \begin{array}{c}\text { AUTOS } \\ \text { BTUS(XIE09 }\end{array} \\ \text { ORANGE } & 8.090 & 5.826 & 12.554 \\ \text { ROCKLAND } & 1.208 & 630 & 10.203 \\ \text { TOTALS } & 9.297 & 6.456 & 22.758\end{array}$

AIRCRAF T

TIAL

BTUS $(X \mid E 09) *$ BTUSIXIEOG)

$\begin{array}{ll}0 & 26,470 \\ 0 & 12.041 \\ 0 & 38.511\end{array}$

- motor gasol ine for autos

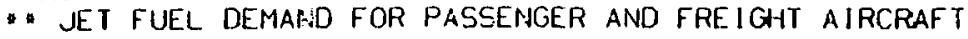


- oilutilitrorgoteiz

OIL DEMAND FOR UTILITY RG+E

1976

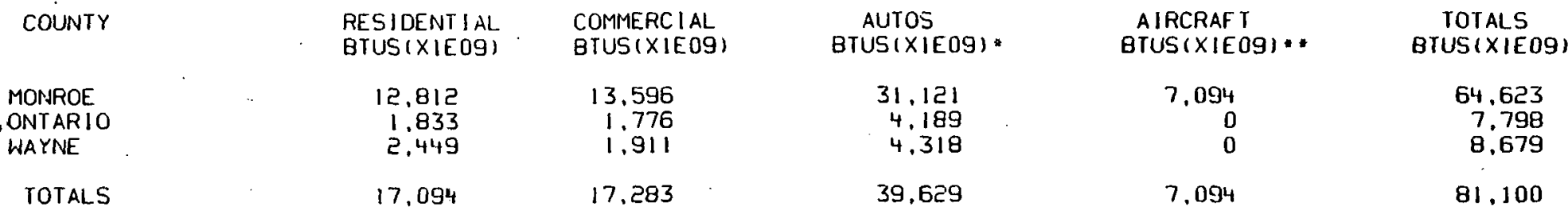

- motor gasol ime for autos

* JET FUEL DEMAND fOR PASSENGER AND FREIGHT AIRCRAFt

*ND GAS: :

COUNTIES WITHOUT GAS

CLINTIJN

ESSEX

FRANK - IN

HAMILTON

LEWIS.

PUTNAM

SCHOHARIE

-FIPELINE (GAS,DISTRI GASI\%

GAS SUPPLY FROM PIPELINE

DISIRI GAS

1976

UTILITY

QUANT ITY

$\$ / M C F$

BROOKLYN UNIOM
$4.183,211$
$\$ 2.167$
4.183 .211
$\$ 2.167$

TOTALS 
-PIPEL INE (GAS, TE.VNESSEE) $\%$

GAS SUPPLY FROM PIPEL INE

1976

UTILITY

QUANTITY

COST

BROOKLYN UNION

CENTRAL HUDSOM

CON ED

LILCO

NYSE +G

ORANGE + ROCKL AND

PENN+ SOUTH

. MCF

\$/MCF

7.397 .173

4.069 .697

$11.028,479$

$1.403,781$

$5,598,660$

14.499 .766

213,553

$\$ 1.089$

$\$ 1.130$

\$1. 095

$\$ 1.210$

$\$ 1.020$

$\$ 1.060$

$\$ 0.936$

TOTALS

44.211 .109

$\$ 1.079$

-PIPEL INE IGAS, TEXAS-EASTERNI $x$ GAS EL INEIGAS TEXAS-EASIERNIX

TEXAS-EASTERN

1976

UTILITY

QUANT I TY
MCF

$\cos T$

\section{BROOKL YN UNION \\ CENTRAL HUDSON \\ CON ED \\ LILCO}

ORANGE +ROCKLAND

TOTALS
$15,049,810$

1.160 .995

$17.492,004$

5.096 .428

$39,832,150$

\$/MCF

$\$ 1.432$

$\$ 1.170$

$\$ 1.263$

$\$ 1.360$

$\$ 1.170$

$\$ 1.334$

PIPEL INE (GAS, TRANSCONTINENTAL) $\%$
GAS SUPPLY FROM PIPELINE TRANSCONT INENTAL

UT IL ITY

BROOKLYN UNION

CON ED

- LILCO

TOTALS

$$
\begin{aligned}
& \text { QUANT ITY } \\
& \text { MCF }
\end{aligned}
$$

$67,665.547$

$60,998,698$

37.957 .637

$166.621,882$
COST
$\$ / M C F$

$\$ 1.123$

$\$ 1.024$

\$1. 120

$\$ 1.086$ 
-pipel ine (gas, Columbia nat) $x$

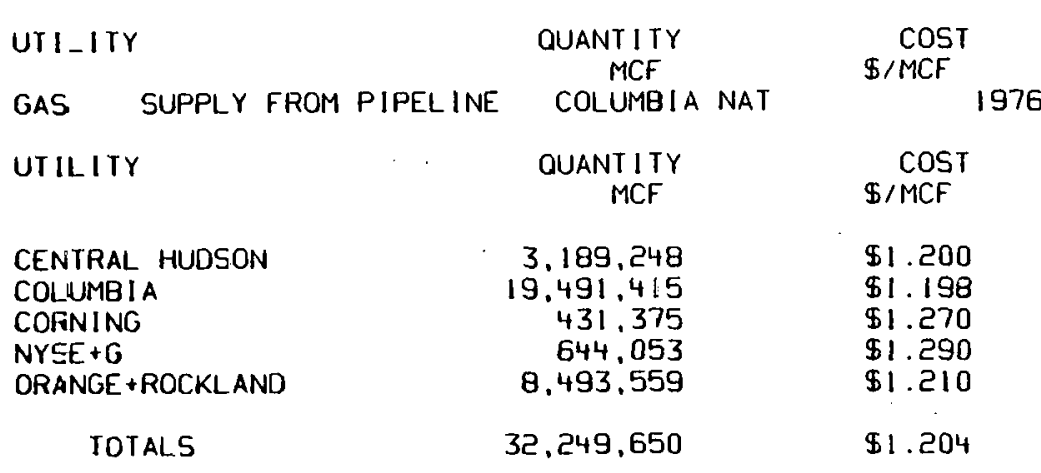

- PIPEL INE IGAS. ALgONQUIN NATI\%

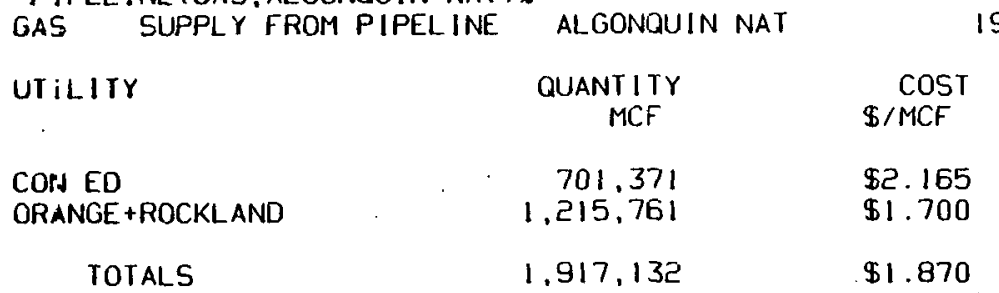

-PIPELINE (GAS, NORTH PENN)\%

GA'S SUPPLY FROM PIPELINE

NORTH PENN

1976

UTILITY

QUANT ITY

COST

CORNING

$14,136,661$

$\$ 1.110$

TOTALS

$14,136,661$

$\$ 1.110$ 
- FIPEL INE (GAS, ASHL AND SYN).

ASHLAND SYN

1976

GL'S SUPPLY FFCM PIPELINE

QUANTITY
MCF

$\cos t$

UTILITY

$11,600,000$

$\$ / M C F$

NATIONAL FUEL

11.600 .000

$\$ 3.261$

TOTALS

$\$ 3.261$

- PIPEL INE IGAS, COLLMBIA SYNI\% G.AS SUPPLY FROF PIPELINE

COLUMBIA SYN

1976

UTILITY

QUANTITY

MCF

$\cos T$

$\$ / \mathrm{MCF}$

NOTIONAL FUEL

$N+S E+G$

180,000

39.212

$\$ 4.406$

DFANGE+ROCKLANO

467,876

$\$ 4.350$

$\$ 4.300$

TOTALS

687.088

$\$ 1.331$

¿PIPEL INE (GAS, BOROERL INE ) * GAS SUPPLY FRIM PIPELINE

$U^{-}$ILITY

BORDERL. INE

1976

N:AGARA MOHAWK

QUANT I TY

COST

10.878

$\$ 1.440$

TOTALS

10,878

$\$ 1.440$ 


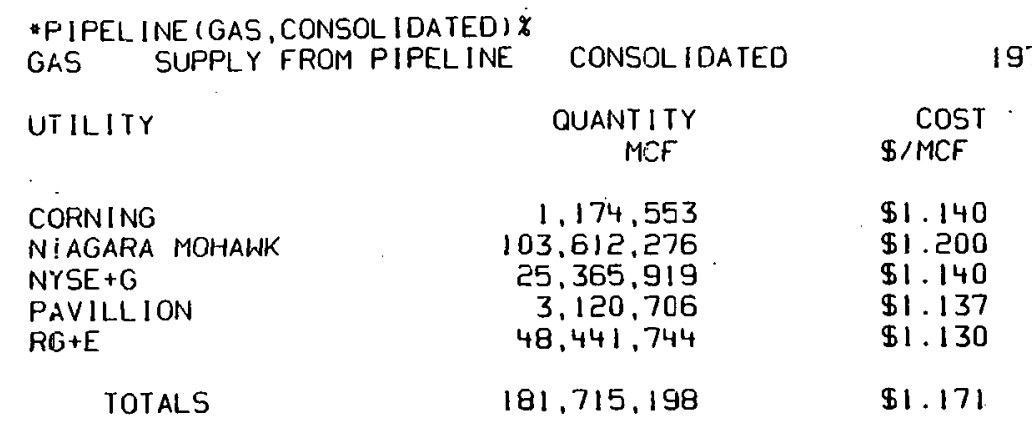

-PIPEL INE (GAS, CORNING)\% GAS SUPPLY FROM PIPELINE CORNING

UTIIITY

QUANTITY

MCF

\$ MCF

NYSE + G

$9,976,675$

$\$ 1.190$

TOTALS

9.976 .675

$\$ 1.190$

-PIPEL INE (Gas, NI AGaRa MOHAWK I\%

CAS SUPPLY FROM PIPELINE NIAGARA MOHAWK

LTILITY

MYSE+G

@YRACUSE SUBURBAN

TOTALS
QUANTITY

214,614

$3,711,534$
976

.140

.137
1.130

1.171 
-PIPEL INE (GAS, ORANGE +ROCKLAND )\%

GAS SUPPLY FROA PIPELINE ORANGE+RDIKLAND.

: 976

UTILITY

OUANT ITY
MCF

$\operatorname{COS}^{\circ}{ }^{\circ}$

NYSE + G

$368 \cdot 1 \bar{c}^{4}$

$\$ 1 \cdot 4+0$

TOTALS

368,124

$\$ 1.4+0$

"RESCOM POLL COUNTYISUFFOLKI\%

POLLUTION FROM RES:DENTIAL AND COMMERCIAL OIL CONSUMPTION

FOR NEW YORK STATE

1976 (1000 TONSI

\section{COUNTY.}

SUFFOLK
AL.DEHYOES

RES

COM

\section{CARBON CIOX}

$3.973,257.0$

$2,259,317.8$
$6,232,574.9$
CARBON MONO

$$
\begin{array}{r}
93.5 \\
1.913 .8 \\
2.007 .3
\end{array}
$$

HYDRO CARBÖN NITROGEN OXIDE

$46: 7$

292.4

NITROEN OXIOE

187.0
767.9

5.767 .9
$5.95 \div .9$
PARTICULATES SILFUR DIOXIDE

PARTICULATES SULFUR DIOXIDE

$\begin{array}{rr}187.0 & 514.2 \\ 1.435 .3 & 3.030 .1 \\ 1.622 .3 & 3.544 .3\end{array}$


- RESCOM POLL PER CTY:X

COUNTY

ALBANY

ALLEGANY

BRONX

BROOME

w

CatTARaugus

CAYUGA

ChaUtaUQUA.

CHEMUNG

CHENAINGO

CLINTON

COLUMBIA

CORTLAND
POLLUTION FROM RESIDENTIAL AND COMMERCIAL OIL CONSUMPIION FOR NEW YORK STATE $1976(1000$ TONS)

\begin{tabular}{|c|c|c|c|c|c|c|c|}
\hline ALDEHYOES & CARBON DIOX & CARBON MONO & HYDRO CARBON & NITROGEN OXIDE & PART ICULATES & SULFUR & $910 \times 10 E$ \\
\hline $\begin{array}{r}8.1 \\
47.0 \\
55.1\end{array}$ & $\begin{array}{r}684,428.5 \\
571.252 .7 \\
1,255,681.2\end{array}$ & $\begin{array}{r}16.1 \\
483.9 \\
500.0\end{array}$ & $\begin{array}{r}8.1 \\
73.9 \\
82.0\end{array}$ & $\begin{array}{r}32.2 \\
1.458 .4 \\
1.490 .6\end{array}$ & $\begin{array}{r}32.2 \\
362.9 \\
395.1\end{array}$ & & $\begin{array}{r}88.6 \\
766.2 \\
854.7\end{array}$ \\
\hline $\begin{array}{l}0.5 \\
1.6 \\
2.1\end{array}$ & $\begin{array}{l}39.074 .5 \\
19,397.0 \\
58,471.5\end{array}$ & $\begin{array}{r}0.9 \\
16.4 \\
17.3\end{array}$ & $\begin{array}{l}0.5 \\
2.5 \\
3.0\end{array}$ & $\begin{array}{r}1.8 \\
49.5 \\
51.4\end{array}$ & $\begin{array}{r}1.8 \\
12.3 \\
14.2\end{array}$ & & $\begin{array}{r}5.1 \\
26.0 \\
31.1\end{array}$ \\
\hline $\begin{array}{r}40.1 \\
196.0 \\
236.1\end{array}$ & $\begin{array}{l}3,404,777.0 \\
2,380,281.3 \\
5,785,058.4\end{array}$ & $\begin{array}{r}80.1 \\
2.016 .2 \\
2.096 .4\end{array}$ & $\begin{array}{r}40.1 \\
308.0 \\
348.1\end{array}$ & $\begin{array}{r}160.2 \\
6,076.7 \\
6.236 .9\end{array}$ & $\begin{array}{r}160.2 \\
1.512 .2 \\
1.672 .4\end{array}$ & & $\begin{array}{r}440.6 \\
3.192 .4 \\
3.633 .0\end{array}$ \\
\hline $\begin{array}{r}3.9 \\
29.3 \\
33.3\end{array}$ & $\begin{array}{l}335.716 .0 \\
355.895 .8 \\
691.611 .9\end{array}$ & $\begin{array}{r}7.9 \\
301.5 \\
309.4\end{array}$ & $\begin{array}{r}3.9 \\
46.1 \\
50.0\end{array}$ & $\begin{array}{r}15.8 \\
908.6 \\
921.4\end{array}$ & $\begin{array}{r}15.8 \\
226.1 \\
241.9\end{array}$ & . & $\begin{array}{r}43.4 \\
477.3 \\
520.8\end{array}$ \\
\hline $\begin{array}{r}1.2 \\
9.2 \\
10.4\end{array}$ & $\begin{array}{l}102.476 .0 \\
111.491 .1 \\
213.967 .1\end{array}$ & $\begin{array}{r}2.4 \\
94.4 \\
96.9\end{array}$ & $\begin{array}{r}1.2 \\
14.4 \\
15.6\end{array}$ & $\begin{array}{r}4.8 \\
284.6 \\
289.5\end{array}$ & $\begin{array}{r}4.8 \\
70.8 \\
75.7\end{array}$ & & $\begin{array}{r}13.3 \\
149.5 \\
162.8\end{array}$ \\
\hline $\begin{array}{r}1.7 \\
11.2 \\
12.9\end{array}$ & $\begin{array}{l}143.259 .0 \\
136.125 .0 \\
279.384 .0\end{array}$ & $\begin{array}{r}3.4 \\
115.3 \\
118.7\end{array}$ & $\begin{array}{l}1.7 \\
17.6 \\
19.3\end{array}$ & $\begin{array}{r}6.7 \\
347.5 \\
3511.3\end{array}$ & $\begin{array}{r}6.7 \\
86.5 \\
93.2\end{array}$ & & $\begin{array}{r}18.5 \\
182.6 \\
201.1\end{array}$ \\
\hline $\begin{array}{l}1.1 \\
3.3 \\
4.3\end{array}$ & $\begin{array}{r}89.998 .0 \\
39.786 .0 \\
129.783 .9\end{array}$ & $\begin{array}{r}2.1 \\
33.7 \\
35.8\end{array}$ & $\begin{array}{l}1.1 \\
5.1 \\
6.2\end{array}$ & $\begin{array}{r}4.2 \\
101.6 \\
105.8\end{array}$ & $\begin{array}{r}4.2 \\
25.3 \\
29.5\end{array}$ & & $\begin{array}{l}11.6 \\
53.4 \\
65.0\end{array}$ \\
\hline $\begin{array}{l}0.8 \\
2.7 \\
3.6\end{array}$ & $\begin{array}{r}71.731 .5 \\
33,269.9 \\
105,001.4\end{array}$ & $\begin{array}{r}1.7 \\
28.2 \\
29.9\end{array}$ & $\begin{array}{l}0.8 \\
4.3 \\
5.1\end{array}$ & $\begin{array}{r}3.4 \\
84.9 \\
88.3\end{array}$ & $\begin{array}{r}3.4 \\
21.1 \\
24.5\end{array}$ & & $\begin{array}{r}9.3 \\
14.6 \\
53.9\end{array}$ \\
\hline $\begin{array}{r}2.4 \\
9.7 \\
12.1\end{array}$ & $\begin{array}{l}203.541 .0 \\
118.316 .6 \\
32 i .857 .6\end{array}$ & $\begin{array}{r}4.8 \\
100.2 \\
105.0\end{array}$ & $\begin{array}{r}2.4 \\
15.3 \\
17.7\end{array}$ & $\begin{array}{r}9.6 \\
302.1 \\
311.6\end{array}$ & $\begin{array}{r}9.6 \\
75.2 \\
81.7\end{array}$ & & $\begin{array}{r}26.3 \\
158.7 \\
185.0\end{array}$ \\
\hline $\begin{array}{r}4.5 \\
19.2 \\
23.7\end{array}$ & $\begin{array}{l}381,131.5 \\
232,869.4 \\
614,000.9\end{array}$ & $\begin{array}{r}9.0 \\
197.3 \\
206.2\end{array}$ & $\begin{array}{r}4.5 \\
30.1 \\
34.6\end{array}$ & $\begin{array}{r}17.9 \\
594.5 \\
612.4\end{array}$ & $\begin{array}{r}17.9 \\
117.9 \\
165.9\end{array}$ & . & $\begin{array}{r}49.3 \\
312.3 \\
361.6\end{array}$ \\
\hline $\begin{array}{r}2.6 \\
9.9 \\
12.6\end{array}$ & $\begin{array}{l}225.003 .5 \\
120.812 .2 \\
345.815 .7\end{array}$ & $\begin{array}{r}5.3 \\
102.3 \\
107.6\end{array}$ & $\begin{array}{r}2.6 \\
15.6 \\
18.3\end{array}$ & $\begin{array}{r}10.6 \\
308.4 \\
319.0\end{array}$ & $\begin{array}{l}10.6 \\
76.8 \\
87.3\end{array}$ & & $\begin{array}{r}29.1 \\
162.0 \\
191.1\end{array}$ \\
\hline $\begin{array}{l}1.0 \\
7.2\end{array}$ & $\begin{array}{l}86,700.0 \\
87.838 .1\end{array}$ & $\begin{array}{r}2.0 \\
74.4\end{array}$ & $\begin{array}{r}1.0 \\
11.4\end{array}$ & $\begin{array}{r}4.1 \\
224.2\end{array}$ & $\begin{array}{r}4.1 \\
55.8\end{array}$ & & $\begin{array}{r}11.2 \\
117.8\end{array}$ \\
\hline
\end{tabular}




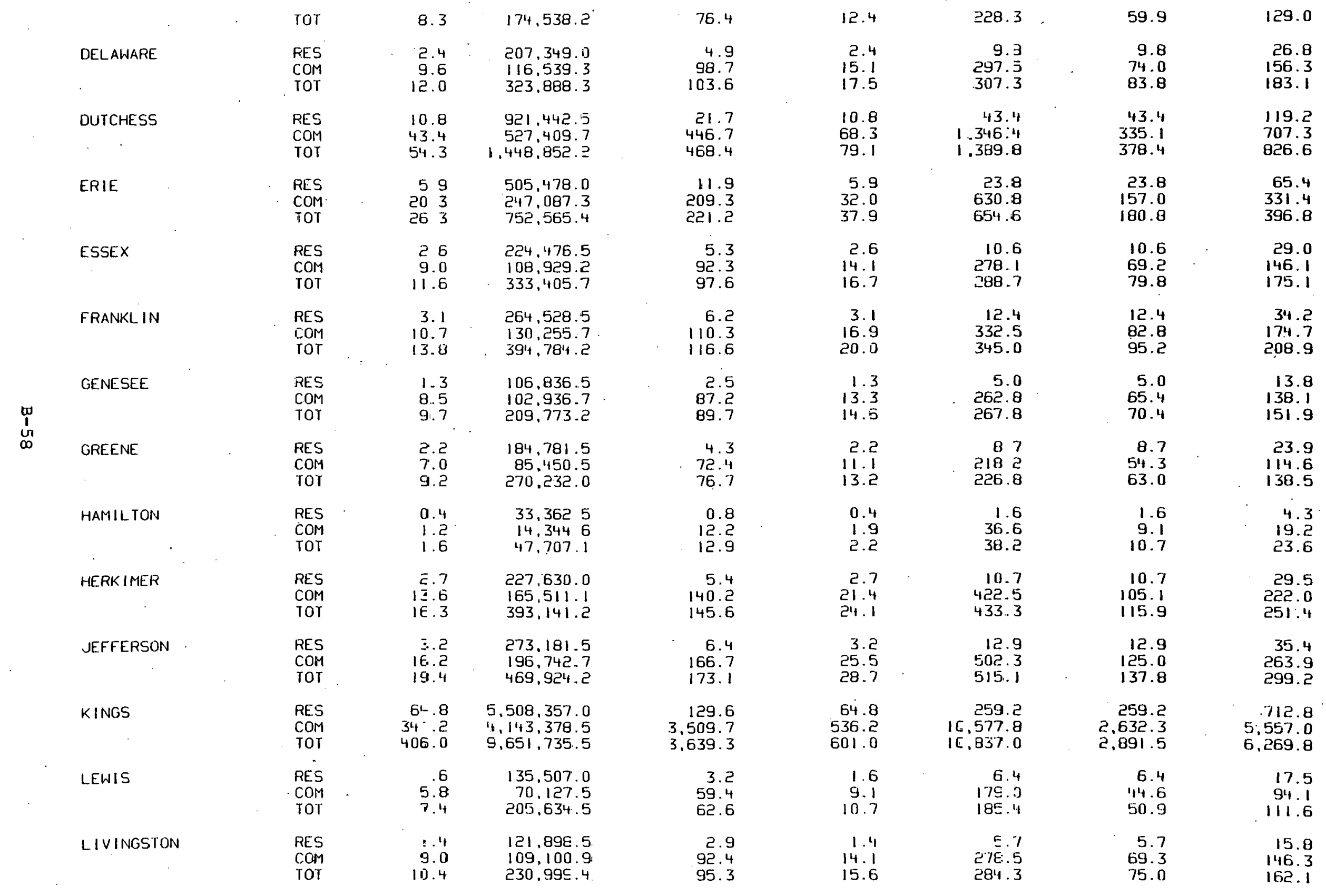




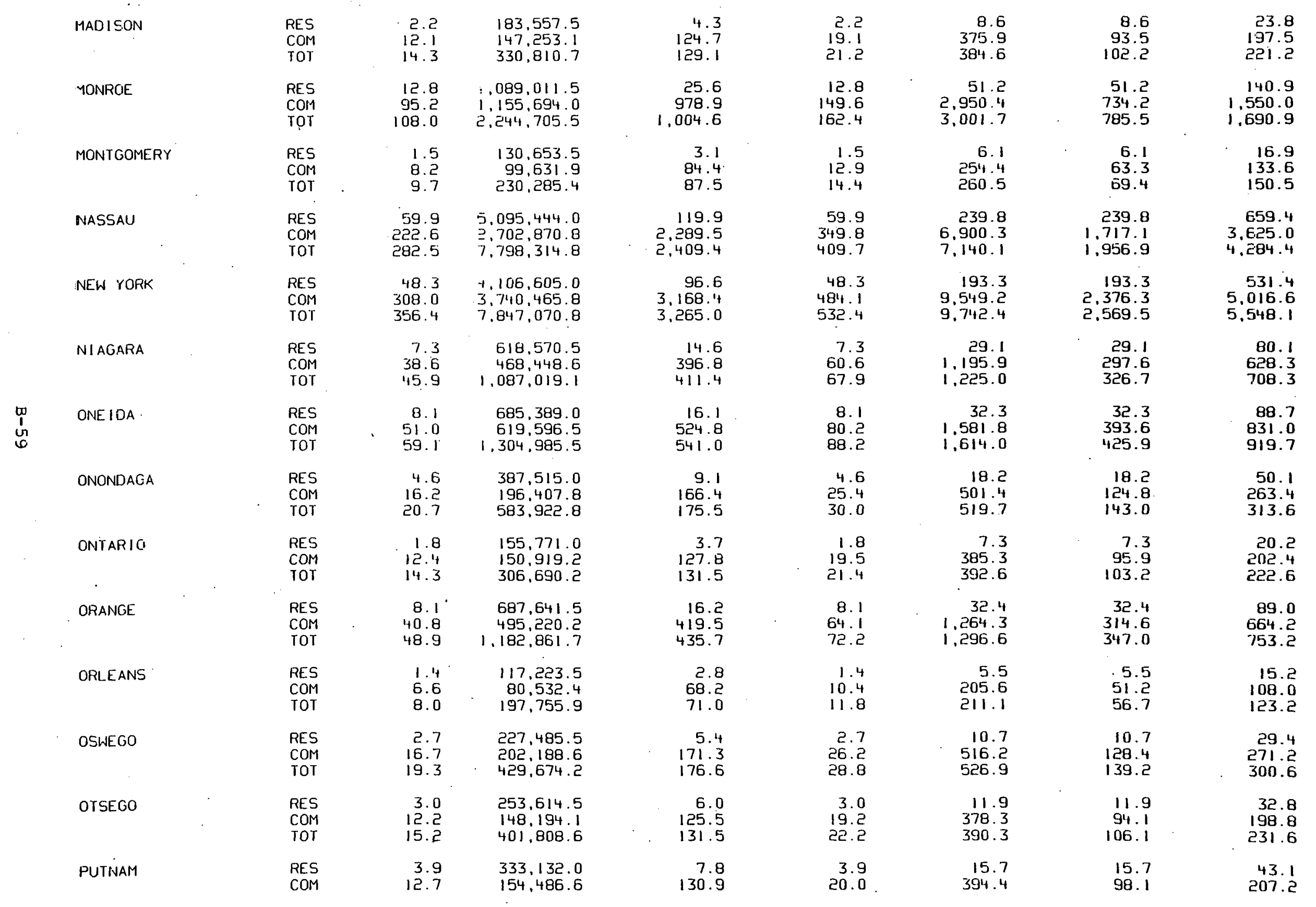




\begin{tabular}{|c|c|c|c|c|c|c|c|c|}
\hline . & ror. & 16.6 & 487.618 .7 & 138.7 & 23.9 & 410.1 & 113.8 & 250.3 \\
\hline QUEENS & $\begin{array}{l}\text { RES } \\
\text { COM } \\
\text {.TOT }\end{array}$ & $\begin{array}{r}60.7 \\
279.4 \\
340.1\end{array}$ & $\begin{array}{l}5.162,305.0 \\
3,392,118.0 \\
8.554,423.0\end{array}$ & $\begin{array}{r}121.5 \\
2.873 .3 \\
2.994 .8\end{array}$ & $\begin{array}{r}60.7 \\
439.0 \\
499.7\end{array}$ & $\begin{array}{r}242.9 \\
8.659 .9 \\
8.902 .8\end{array}$ & $\begin{array}{r}2142.9 \\
2.155 .0 \\
2.397 .9\end{array}$ & $\begin{array}{r}668.1 \\
4.549 .1 \\
5.217 .5\end{array}$ \\
\hline RENSSELAER & $\begin{array}{l}\text { RES } \\
\text { COM } \\
\text { TOT }\end{array}$ & $\begin{array}{r}5.2 \\
25.5 \\
30.7\end{array}$ & $\begin{array}{l}438,005.0 \\
309,693.3 \\
747,698.3\end{array}$ & $\begin{array}{r}10.3 \\
262.3 \\
272.6\end{array}$ & $\begin{array}{r}5.2 \\
40.1 \\
45.2\end{array}$ & $\begin{array}{r}20.6 \\
790.6 \\
811.2\end{array}$ & $\begin{array}{r}20.6 \\
196.7 \\
217.4\end{array}$ & $\begin{array}{r}56.7 \\
115.4 \\
472.0\end{array}$ \\
\hline RICHMOND & $\begin{array}{l}\text { RES } \\
\text { COM } \\
\text { TOT }\end{array}$ & $\begin{array}{r}7.7 \\
41.5 \\
19.3\end{array}$ & $\begin{array}{r}658.112 .5 \\
504.306 .7 \\
1.162 .419 .2\end{array}$ & $\begin{array}{r}15.5 \\
427.2 \\
442.7\end{array}$ & $\begin{array}{r}7.7 \\
65.3 \\
73.0\end{array}$ & $\begin{array}{r}31.0 \\
1.287 .5 \\
1.318 .4\end{array}$ & $\begin{array}{r}31.0 \\
320.4 \\
351.4\end{array}$ & $\begin{array}{r}85.2 \\
676.4 \\
761.5\end{array}$ \\
\hline ROCK!_AND & $\begin{array}{l}\text { RES } \\
\text { COM } \\
\text { TOT }\end{array}$ & $\begin{array}{l}1.2 \\
11.4 \\
5.6\end{array}$ & $\begin{array}{r}102.637 .5 \\
53.571 .3 \\
156.208 .8\end{array}$ & $\begin{array}{r}2.4 \\
45.4 \\
47.8\end{array}$ & $\begin{array}{l}1.2 \\
6.9 \\
8.1\end{array}$ & $\begin{array}{r}4.8 \\
136.8 \\
141.6\end{array}$ & $\begin{array}{r}4.8 \\
34.0 \\
38.9\end{array}$ & $\begin{array}{l}13.3 \\
71.8 \\
85.1\end{array}$ \\
\hline SARATOGA & $\begin{array}{l}\text { RES } \\
\text { COM } \\
\text { TOT }\end{array}$ & $\begin{array}{l}14.6 \\
23.3 \\
27.9\end{array}$ & $\begin{array}{l}392.904 .0 \\
282.704 .9 \\
675.608 .9\end{array}$ & $\begin{array}{r}9.2 \\
239.5 \\
248.7\end{array}$ & $\begin{array}{r}4.6 \\
36.6 \\
41.2\end{array}$ & $\begin{array}{r}18.5 \\
721.7 \\
740.2\end{array}$ & $\begin{array}{r}18.5 \\
179.6 \\
198.1\end{array}$ & $\begin{array}{r}50.8 \\
379.2 \\
430.0\end{array}$ \\
\hline SCHENECTADY & $\begin{array}{l}\text { RES } \\
\text { COM } \\
\text { ror }\end{array}$ & $\begin{array}{r}4.5 \\
24.9 \\
29.4\end{array}$ & $\begin{array}{l}384.650 .5 \\
301.971 .9 \\
686.622 .4\end{array}$ & $\begin{array}{r}9.1 \\
255.8 \\
264.8\end{array}$ & $\begin{array}{r}4.5 \\
39.1 \\
43.6\end{array}$ & $\begin{array}{r}18.1 \\
770.9 \\
789.0\end{array}$ & $\begin{array}{r}18.1 \\
191.8 \\
209.9\end{array}$ & $\begin{array}{r}49.8 \\
105.0 \\
454.8\end{array}$ \\
\hline SCHOHARIE & $\begin{array}{l}\text { RES } \\
\text { COM } \\
\text { TOT }\end{array}$ & $\begin{array}{l}1.7 \\
6.0 \\
7.6\end{array}$ & $\begin{array}{r}141.669 .5 \\
72.586 .6 \\
214.256 .1\end{array}$ & $\begin{array}{r}3.3 \\
61.5 \\
64.8\end{array}$ & $\begin{array}{r}1.7 \\
9.4 \\
11.1\end{array}$ & $\begin{array}{r}6.7 \\
185.3 \\
192.0\end{array}$ & $\begin{array}{r}6.7 \\
46.1 \\
52.8\end{array}$ & $\begin{array}{r}18.3 \\
97.4 \\
115.7\end{array}$ \\
\hline SCHUYLER & $\begin{array}{l}\text { RES } \\
\text { COM } \\
\text { TOT }\end{array}$ & $\begin{array}{l}0.6 \\
3.0 \\
3.5\end{array}$ & $\begin{array}{l}49.172 .5 \\
35,858.9 \\
85.031 .4\end{array}$ & $\begin{array}{r}1.2 \\
30.4 \\
31.5\end{array}$ & $\begin{array}{l}0.6 \\
4.6 \\
5.2\end{array}$ & $\begin{array}{r}2.3 \\
91.5 \\
93.9\end{array}$ & $\begin{array}{r}2.3 \\
22.8 \\
25.1\end{array}$ & $\begin{array}{r}6.4 \\
48.1 \\
54.5\end{array}$ \\
\hline SENECA & $\begin{array}{l}\text { RES } \\
\text { COM } \\
\text { TOT }\end{array}$ & $\begin{array}{l}0.8 \\
5.0 \\
5.8\end{array}$ & $\begin{array}{r}65.407 .5 \\
61.123 .5 \\
126.531 .0\end{array}$ & $\begin{array}{l}1.5 \\
51.8 \\
53.3\end{array}$ & $\begin{array}{l}0.8 \\
7.9 \\
8.7\end{array}$ & $\begin{array}{r}3.1 \\
156.0 \\
159.1\end{array}$ & $\begin{array}{r}3.1 \\
38.8 \\
41.9\end{array}$ & $\begin{array}{r}8.5 \\
82.0 \\
90.4\end{array}$ \\
\hline STEUBEN & $\begin{array}{l}\text { RES } \\
\text { COM } \\
\text { TOT }\end{array}$ & $\begin{array}{l}1.8 \\
12.5 \\
1.4 .4\end{array}$ & $\begin{array}{l}156.587 .0 \\
152.363 .3 \\
308.950 .4\end{array}$ & $\begin{array}{r}3.7 \\
129.1 \\
132.7\end{array}$ & $\begin{array}{r}1.8 \\
19.7 \\
21.6\end{array}$ & $\begin{array}{l}.7 .4 \\
389.0 \\
396.3\end{array}$ & $\begin{array}{r}7.4 \\
96.8 \\
104.2\end{array}$ & $\begin{array}{r}20.3 \\
204.3 \\
224.6\end{array}$ \\
\hline ST. LAWRENCE & $\begin{array}{l}\text { RES } \\
\text { COM } \\
\text { TOT }\end{array}$ & $\begin{array}{r}5.5 \\
26.4 \\
31.9\end{array}$ & $\begin{array}{l}467.381 .0 \\
319.989 .3 \\
787.370 .3\end{array}$ & $\begin{array}{r}11.0 \\
271.0 \\
282.0\end{array}$ & $\begin{array}{r}5.5 \\
41.4 \\
46.9\end{array}$ & $\begin{array}{r}22.0 \\
816.9 \\
838.9\end{array}$ & $\begin{array}{r}22.0 \\
203.3 \\
225.3\end{array}$ & $\begin{array}{r}60.5 \\
429.2 \\
489.6\end{array}$ \\
\hline SUFFOLK & $\begin{array}{l}\text { RES } \\
\text { COM } \\
\text { TOT }\end{array}$ & $\begin{array}{r}46.7 \\
186.1 \\
232.8\end{array}$ & $\begin{array}{l}3.973 .257 .0 \\
2.259 .317 .8 \\
6.232 .574 .9\end{array}$ & $\begin{array}{r}93.5 \\
1.913 .8 \\
2.007 .3\end{array}$ & $\begin{array}{r}46.7 \\
292.4 \\
339.1\end{array}$ & $\begin{array}{r}187.0 \\
5.767 .9 \\
5.954 .9\end{array}$ & $\begin{array}{r}187.0 \\
1.435 .3 \\
1.622 .3\end{array}$ & $\begin{array}{r}514.2 \\
3.030 .1 \\
3.544 .3\end{array}$ \\
\hline SULLIVAN & $\begin{array}{l}\text { RES } \\
\text { COM } \\
\text { TOT }\end{array}$ & $\begin{array}{r}4.1 \\
13.8 \\
17.9\end{array}$ & $\begin{array}{l}346.664 .0 \\
167.351 .4 \\
514.01 E .4\end{array}$ & $\begin{array}{r}8.2 \\
141.8 \\
149.9\end{array}$ & $\begin{array}{l}4.1 \\
21.7 \\
25.7\end{array}$ & $\begin{array}{r}1 E .3 \\
127.2 \\
143.6\end{array}$ & $\begin{array}{r}16.3 \\
106.3 \\
122.6\end{array}$ & $\begin{array}{r}44.9 \\
224.4 \\
269.3\end{array}$ \\
\hline
\end{tabular}




\begin{tabular}{|c|c|c|c|c|c|c|c|c|}
\hline TIOGA & $\begin{array}{l}\text { RES } \\
\text { COM } \\
\text { TOT }\end{array}$ & $\begin{array}{r}2.1 \\
9.4 \\
11.5\end{array}$ & $\begin{array}{r}180.786 .5 \\
114.297 .8 \\
295.084 .3\end{array}$ & $\begin{array}{r}4.3 \\
96.8 \\
101.1\end{array}$ & $\begin{array}{r}2.1 \\
14.8 \\
16.9\end{array}$ & $\begin{array}{r}8.5 \\
291.8 \\
300.3\end{array}$ & $\begin{array}{r}8.5 \\
72.6 \\
81.1\end{array}$ & $\begin{array}{r}23.4 \\
153.3 \\
176.7\end{array}$ \\
\hline TOMPKINS & $\begin{array}{l}\text { RES } \\
\text { COM } \\
\text { TCT }\end{array}$ & $\begin{array}{l}11.4 \\
11.6 \\
13.0\end{array}$ & $\begin{array}{r}119.450 .5 \\
140.673 .3 \\
260.123 .8\end{array}$ & $\begin{array}{r}2.8 \\
119.2 \\
122.0\end{array}$ & $\begin{array}{r}1.4 \\
18.2 \\
19.6\end{array}$ & $\begin{array}{r}5.6 \\
359.1 \\
364.8\end{array}$ & $\begin{array}{r}5.6 \\
89.4 \\
95.0\end{array}$ & $\begin{array}{r}15.5 \\
188.7 \\
204.1\end{array}$ \\
\hline ULSTER & $\begin{array}{l}\text { RES } \\
\text { COM } \\
\text { TOT }\end{array}$ & $\begin{array}{r}7.9 \\
28.3 \\
36.2\end{array}$ & $\begin{array}{r}671.219 .5 \\
343.256 .4 \\
1.014 .475 .9\end{array}$ & $\begin{array}{r}15.8 \\
290.8 \\
306.6\end{array}$ & $\begin{array}{r}7.9 \\
44.4 \\
52.3\end{array}$ & $\begin{array}{r}31.6 \\
876.3 \\
907.9\end{array}$ & $\begin{array}{r}31.6 \\
218.1 \\
219.7\end{array}$ & $\begin{array}{r}86.9 \\
460.4 \\
547.2\end{array}$ \\
\hline WARREN & $\begin{array}{l}\text { RES } \\
\text { COM } \\
\text { TOT }\end{array}$ & $\begin{array}{r}2.4 \\
12.0 \\
14.4\end{array}$ & $\begin{array}{l}206.856 .0 \\
145.599 .9 \\
352.455 .9\end{array}$ & $\begin{array}{r}4.9 \\
123.3 \\
128.2\end{array}$ & $\begin{array}{r}2.4 \\
18.8 \\
21.3\end{array}$ & $\begin{array}{r}9.7 \\
371.7 \\
381.4\end{array}$ & $\begin{array}{r}9.7 \\
92.5 \\
102.2\end{array}$ & $\begin{array}{r}26.8 \\
195.3 \\
222.0\end{array}$ \\
\hline WASHINGTON & $\begin{array}{l}\text { RES } \\
\text { COM } \\
\text { TOT }\end{array}$ & $\begin{array}{r}2.2 \\
9.5 \\
11.7\end{array}$ & $\begin{array}{l}188.130 .5 \\
115.428 .3 \\
303.558 .8\end{array}$ & $\begin{array}{r}4.4 \\
97.8 \\
102.2\end{array}$ & $\begin{array}{r}2.2 \\
14.9 \\
17.2\end{array}$ & $\begin{array}{r}8.9 \\
294.7 \\
303.5\end{array}$ & $\begin{array}{r}8.9 \\
73.3 \\
82.2\end{array}$ & $\begin{array}{r}24.3 \\
154.8 \\
179.2\end{array}$ \\
\hline WAYNE & $\begin{array}{l}\text { RES } \\
\text { COM } \\
\text { TOT }\end{array}$ & $\begin{array}{r}2.4 \\
13.4 \\
15.8\end{array}$ & $\begin{array}{l}208,165.0 \\
162,452.0 \\
370,617.0\end{array}$ & $\begin{array}{r}4.9 \\
137.6 \\
142.5\end{array}$ & $\begin{array}{r}2.4 \\
21.0 \\
23.5\end{array}$ & $\begin{array}{r}9.8 \\
414.7 \\
424.5\end{array}$ & $\begin{array}{r}9.8 \\
103.2 \\
113.0\end{array}$ & $\begin{array}{r}26.9 \\
217.9 \\
244.8\end{array}$ \\
\hline WESTCHESTER & $\begin{array}{l}\text { RES } \\
\text { COM } \\
\text { TOT }\end{array}$ & $\begin{array}{l}29.1 \\
133.1 \\
162.2\end{array}$ & $\begin{array}{l}2.477,002.0 \\
1.615 .951 .1 \\
4.092,953.1\end{array}$ & $\begin{array}{r}58.3 \\
1.368 .8 \\
1.427 .1\end{array}$ & $\begin{array}{r}29.1 \\
209.1 \\
238.3\end{array}$ & $\begin{array}{r}116.6 \\
4.125 .4 \\
4.242 .0\end{array}$ & $\begin{array}{r}116.6 \\
1.026 .6 \\
1.143 .2\end{array}$ & $\begin{array}{r}320.6 \\
2.167 .3 \\
2.487 .8\end{array}$ \\
\hline WYOMING & $\begin{array}{l}\text { RES } \\
\text { COM } \\
\text { TOT. }\end{array}$ & $\begin{array}{l}0.7 \\
5.0 \\
5.7\end{array}$ & $\begin{array}{r}57.638 .5 \\
60.857 .5 \\
118.495 .9\end{array}$ & $\begin{array}{l}1.4 \\
51.5 \\
52.9\end{array}$ & $\begin{array}{l}0.7 \\
7.9 \\
8.6\end{array}$ & $\begin{array}{r}2.7 \\
155.4 \\
158.1\end{array}$ & $\begin{array}{r}2.7 \\
38.7 \\
41.4\end{array}$ & $\begin{array}{r}7.5 \\
81.6 \\
89.1\end{array}$ \\
\hline YATES & $\begin{array}{l}\text { RES } \\
\text { COM } \\
\text { TOT }\end{array}$ & $\begin{array}{l}0.7 \\
3.5 \\
4.2\end{array}$ & $\begin{array}{l}56,542.0 \\
42,860.4 \\
99,402.4\end{array}$ & $\begin{array}{r}1.3 \\
36.3 \\
37.6\end{array}$ & $\begin{array}{l}0.7 \\
5.5 \\
6.2\end{array}$ & $\begin{array}{r}2.7 \\
109.4 \\
112.1\end{array}$ & $\begin{array}{r}2.7 \\
27.2 \\
29.9\end{array}$ & $\begin{array}{r}7.3 \\
57.5 \\
64.8\end{array}$ \\
\hline TOTAL & & 3.102 .9 & 76.300 .215 .2 & 27.523 .5 & 4.573 .1 & 81.877 .9 & 21.967 .9 & 47.731 .4 \\
\hline
\end{tabular}


"RESCOM POLL PER IJTIL * *

UTILITY

CENTRAL HUDSON

CON ED

LILCO

on

NIAGARA MOHAWK

NYSE +G

ORANGE + ROCKLAND

$R G+E$

TOTAL
POULUTION FROM RESIDENTIAL AND COMMERCIAL OIL CONSUMPTION FOR NEN YOFK STATE 1976 (1000 TONS)

ALDEHYDES

CARBON DIOX

CARBON MONO

HYDRO CARBGN NITROGEN OXIDE

21.7

446.7

468.4

$\begin{array}{rr}42.4 & 527.409 .7 \\ 54.3 & 1,448.852 .2\end{array}$

$4 C .1 \quad 3.404 .777 .0$

$19 \mathrm{E} .0 \quad 2.380 .281 .3$

23E. 1

$5,785,058.4$

$59.9 \quad 5.095 .444 .0$

$222.6 \quad 2.702 .870 .8$

$\begin{array}{ll}222.6 & 2.702 .870 .8 \\ 282.5 & 7.798 .314 .8\end{array}$

80.1
5.016 .5

$\begin{array}{rr}\text { a.1 } & 684.428 .5 \\ 17.0 & 571.252 .7\end{array}$

.55 .1

1.255 .681 .2

0.5
2.6
2.1

39.074 .5

19.397 .0

58.471 .5

TOT

RES

COM

TOT

8. 1

40.8

$687,641.5$

495.220 .2

1.182 .861 .7

12.8

95.2

$1,089,011.5$

$1,155,694.0$

785.9

19.773 .345 .3
כ.096. 4

$$
\begin{array}{r}
119.9 \\
2.289 .5
\end{array}
$$

$? .289 .5$
2.409 .4

16.1

483.9

500.0

0.9

16.4
17.3

16.2

419.5

435.7

25.6

978.9

1.004 .5

6.931 .7
PARTICULATES SULFUR DIOXIDE

10.8
68.3
79.1
40.1
308.0
348.1
59.9
349.8
409.7

43.4

1.316 .4

1. 389.8

160.2

6.076 .7

6.236 .9

239.8
6.900 .3

6.900 .3
7.140 .1

$8.1 \quad, \quad 3 \bar{F} .2$
73.9

$\begin{array}{ll}73.9 & 1.45 E .4 \\ 82.0 & 1.490 .6\end{array}$

0.5

2. 5

4.8

49.5

32.4

8.1

64.1
72.2

$1,264 \cdot 3$

1. 296.6

12.8

149.6

51.5

2. 950.4

$3,00.7$

20.607 .0

\section{PARTICULATES SULFUR DIOXIDE}

\begin{tabular}{|c|c|}
\hline $\begin{array}{r}43.4 \\
335.1 \\
378.4\end{array}$ & $\begin{array}{l}119.2 \\
707.3 \\
826.6\end{array}$ \\
\hline $\begin{array}{r}160.2 \\
1.512 .2 \\
1.672 .4\end{array}$ & $\begin{array}{r}440.6 \\
3.192 .4 \\
3.633 .0\end{array}$ \\
\hline $\begin{array}{r}239.8 \\
1.717 .1 \\
1.956 .9\end{array}$ & $\begin{array}{r}659.4 \\
3.625 .0 \\
1.284 .4\end{array}$ \\
\hline $\begin{array}{r}32.2 \\
362.9 \\
395.1\end{array}$ & $\begin{array}{r}88.6 \\
766.2 \\
851.7\end{array}$ \\
\hline
\end{tabular}

1.8

1.8
12.3
14.2

5.1

26.0

32.4

314.6

347.0

89.0

664.2

$1+5.90 .9$

$\begin{array}{ll}734.2 & 1.550 .0\end{array}$

1.156 .4

$1,690.9$

$5.549 .4 \quad 12,073.9$ 
- REscom poll utillityicentral hudSONi\%

POLLUTIOIN FROM RESIDENTIAL AND COMMERCIAL OIL CONSUMPIION FOR NEW YORK STATE 1976 (1000 TONS)

COUNTY

DUTCHESS

GREENE

PUTNAM

ULSTER

\section{CENTRAL HUDSON} ALDEHYDES CARBON DIOX CARBON MONO HYDRO CARBON NITROGEN OXIDE

21.7
446.7
468.4

10.8

68.3
79.1

43.4

.316 .4
.389 .8

$1,448.852 .2$

184.781 .5

$\begin{array}{rr}2.2 & 184.781 .5 \\ 7.0 & 85.450 .5 \\ 9.2 & 270.232 .0\end{array}$

$333,132.0$

154.486 .6

487.619 .7

$671,219.5$

$343,256 \cdot 4$

$1,014,475.9$

$116.3 \quad 3.221 .178 .7$
4.3

72.4

7.8

130.9

138.7

. 5.5

11.1

13.2

3.9

20.0

23.9

7.9

44.4

52.3

290.8

990.4

168.6

8.7

226.8

15.7

394.4

410.1

31.6

876. 3

.907 .9

PARTICULATES SULFUR DIOXIDE

43.4

119.2

707.3
826.6

378.4

$54.3 \quad 114.6$

$\begin{array}{ll}63.0 & 138.5\end{array}$

15.7

138.5

98.1

43.1

207.2

250.3

31.6

218. 1

86.9

460.4
517.2

249.7

804.9

1.762 .6 
*RESCOM POLL UTILITYICON EDI:

POLLUTION FROM RESIDENTIAL ANO CONMERCIAL DIL CONSUMPTIDV FOR NEA YORK STATE
1976,1000 TONSI

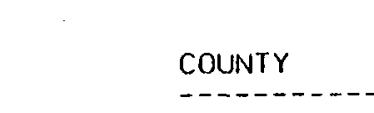

BRONX

KINGS

NEW YORK

OUEENS

RICHMOND

WESTCHESTER

TOTAL
CON ED

ALDEH'DES CARBON DIOK

\section{$3,404,777: 0$}

$\begin{array}{rr}10.1 & 3.404 .777 .0 \\ 196.0 & E .380 .281 .3\end{array}$

$\begin{array}{ll}196.0 & E .380 .281 .3 \\ 236.1 & 5.785 .058 .4\end{array}$

$\begin{array}{rr}64.8 & 5.508 .357 .0 \\ 3.11 & 4.143 .376 .5\end{array}$

$\begin{array}{ll}311.2 & 4.143 .376 .5 \\ 1101.0 & 9.651 .73 E .5\end{array}$

$9.651 .73 E .5$

43.

303.0

$4,106,605.0$

$3.740,465.8$

COM

TOT

RES

COM

63.7

273.4

$3+10.1$

$5,162,305.0$

$5.162,305.0$
$3.392,118.0$

8.554 .423 .0

7.7

41.5
49.3

\section{$658,112.5$}

COM

$504,306.7$

29.1 2.477 .002 .0

$133.1 \quad 1.615 .95 \div .1$

IE2.2 4.092 .953 .1

$1.550 .0 \quad 37.093 .660 .0$
CARBON MONO HYDRO CARBON

80.1
2.016 .2
2.096 .4

129.6
3.509 .7

3.639 .3

96.6

3.168 .4

3.265 .0

121.5
2.873 .3

2.873 .3
2.994 .8

15.5

427.2

58.3
$1,368.8$

$1,427.1$

$13,865.2$

$\begin{array}{rr}40.1 & 160.2 \\ 308.0 & E .076 .7 \\ 348.1 & E .236 .9 \\ 64.8 & 259.2 \\ 536.2 & 11.1577 .8 \\ 601.0 & 10.837 .0 \\ 48.3 & 192.3 \\ 484.1 & 9.549 .2 \\ 532.4 & 9.742 .1 \\ 60.7 & 242.9 \\ 439.0 & 9.659 .9 \\ 499.7 & B .902 .8 \\ 7.7 & 31.0 \\ 65.3 & 1.287 .5 \\ 73.0 & 1.318 .4 \\ 29.1 & 116.6 \\ 209.1 & 4.125 .4 \\ 239.3 & 4.242 .0 \\ 292.5 & 41.279 .6\end{array}$

PARTICULATES SULFUR DIOXIDE

$\begin{array}{rr}160.2 & 440.6 \\ 1.512 .2 & 3.192 .4 \\ 1.672 .4 & 3.633 .0 \\ 259.2 & 712.8 \\ 2.632 .3 & 5.557 .0 \\ 2.891 .5 & 6.269 .8 \\ 193.3 & 531.4 \\ 2.376 .3 & 5.016 .6 \\ 2.569 .5 & 5.548 .1 \\ 242.9 & 668.1 \\ 2.155 .0 & 4.549 .4 \\ 2.397 .9 & 5.217 .5 \\ 31.0 & 85.2 \\ 320.4 & 676.4 \\ 351.4 & 761.5 \\ 116.6 & 320.6 \\ 1.026 .6 & 2.167 .3 \\ 1.113 .2 & 2.487 .8 \\ 11.025 .9 & 23.917 .8\end{array}$


*RESCOM POLL UTILITYILILCOI\%

$\begin{array}{ll}\text { W } & \text { COUNTY } \\ \text { ô } & \text { NASSAU }\end{array}$

SUFFOLK

TOTAL

POLLJTION FROM RESIDENTIAL AND COMMERC IAL OIL CONSUMPTION

FOR NEW YORK STATE

1976 ( 1000 TONS )

LILCO
CARBON DIOX

ALUEHYDES CARBON DIOX

$59 \cdot 9$
222.6
282.5

\subsection{5 .444 .0}

$2,702,870.8$

$7,798,314.8$

146.7

$1,6.7$

186.1
232.8

$3,973,257.0$

3.259 .317 .8

$2.259,317.8$
$6.232,574.9$

515.3
CARBON MONO -

119.9
2.289 .5
2.409 .4

93.5
1.913 .8

2.007 .3

4.416 .6
HYORO CARBON NITROGEN OXIDE

59.9

349.8

409.7

46.7

292.1

339.1

748.9

NITROGEN OXIDE

239.8
6.900 .3
7.140 .1
187.0
5.767 .9
5.954 .9
13.094 .9

PARTICULATES SULFUR DIOXIDE

$\begin{array}{rr}239.8 & 659.4 \\ 1.717 .1 & 3.625 .0 \\ 1.956 .9 & 4.284 .4 \\ 187.0 & 514.2 \\ 1.435 .3 & 3.030 .1 \\ 1.622 .3 & 3.544 .3 \\ 3.579 .2 & 7.828 .8\end{array}$


- Rescom poll Utility(niagara rohahki\%

POLLUTION FROM FESIDENTIAL AND COMMERCIAL OIL CONSUMPTION

FOR NEW YCFK 'STATE 1976 (1000 TONS)

COUNTY

$-\cdots--$

ALBANY

CATTARAUGUS

CLINTON

pr

COLUMBIA

CORTLAND

ERIE

ESSEX

FRANKL. IN

GENESEE

HAMILTON

HIERKIMER
NIAGAFA MJHAWK

CARBON DIOX ZARBCN MONO HYYRO CARBON NITROGEN DXIDE

ALDEHYOES

16.1

483.9
500.0

571.252 .7
.255 .681 .2

2.4

111.491.

213.967 .1

94.4
96.9

89.998.0

39.786 .0
129.783 .9

3.3
1.3

381.131 .5

232.869 .4

$614,000.9$

225.003 .5
$120.812 . ?$

$120.812 . ?$
345.815 .7

86.700. D

87.838 .1
174.538 .2

$505,478.0$

247.087 .3

$752,565.4$

224.476 .5

108.929 .2
33.3 .405 .7

COM

TOT

2.6
9.0
1.1 .6

264.528 .5

394.784 .2

COM

3.1
10.7

13.8

$\begin{array}{ll}1.3 & 106.836 .5 \\ 8 . .5 & 102.936 .7 \\ 9.7 & 209.773 .2\end{array}$

COM

RES

TOT

RES $\begin{array}{ll}1 . .3 & 106.836 .5 \\ 8.5 & 102.936 .7 \\ 9.7 & 209.773 .2\end{array}$

$\begin{array}{ll}1 . .3 & 106.836 .5 \\ 8.5 & 102.936 .7 \\ 9.7 & 209.773 .2\end{array}$

$\begin{array}{ll}0.4 & 33.362 .5 \\ 1.2 & 14.344 .6\end{array}$

227.630 .0
2.1
33.7

35.8

9.0

197.3
206.2

5.3
102.3

102.3
107.6

2.0
74.4

74.4
76.4

11.9

209.3
221.2

5.3
92.3

97.6

6.2

110.3

116.6

2.5
87.2

87.2
89.7

0.8

12.9

5.4
8.1

73.9
82.0

1.2

14.4

1.1

5.1
$6 . \bar{c}$

4.5

30.1
34.6

2.6

2.6
15.6

18.3

1.0

11.4
12.4

5.9

32.0
37.9

2. 6

14.1
16.7

3.1

.16 .9

20.0

1.3

13.3

14.6

0.4

1. 3

2.7
32.2
1.458 .4

1.490 .6

$4 . \mathrm{B}$

284.6
289.5

4.2

101.5
105.3

17.3

594.5
612.4

10.6
308.4

319.0

4.1
224.2

228. 3

23.8

630.8

654.6

10.6

278.1
288.7

12.4

332.5

$31+5.0$

5.0

262.8

267.8

1.6
36.6

38.2

10.7
PARTICULATES SULFUR DIOXIDE

362.9
395.1

88.6

766.2

4.8
70.8

75.7

13.3

149.5

4.2

25.3
29.5

11.6

53.4
65.0

17.9

147.9

49.3

312.3

10.6

76.8

כ9. 1

97. 3

162.0

191.1

4.1
55.8

55.8
59.9

11.2

129.0

23. 8

157.0

65.4

10.6

69.2
79.8

396.8

12.4

82.8

95.2

5. 0

65.1

70.4

29.0

146.1
175.1

34.2

174.7

208.9

13.8
138.1

138.1
151.9

1.6
9.1

10.7

4.3

19.2

23.6

10.7

29.5 


\begin{tabular}{|c|c|c|c|c|c|c|c|c|}
\hline r. & $\begin{array}{l}\text { COM } \\
\text { TOT }\end{array}$ & $\begin{array}{l}13.6 \\
16.3\end{array}$ & $\begin{array}{l}165.511 .1 \\
393.141 .2\end{array}$ & $\begin{array}{l}140.2 \\
145.6\end{array}$ & $\begin{array}{l}21.4 \\
24.1\end{array}$ & $\begin{array}{l}422.5 \\
433.3\end{array}$ & $\begin{array}{l}105.1 \\
115.9\end{array}$ & $\begin{array}{l}222: 0 \\
251.4\end{array}$ \\
\hline JEFFEFISON & $\begin{array}{l}\text { RES } \\
\text { COM } \\
\text { TOT }\end{array}$ & $\begin{array}{r}3.2 \\
16.2 \\
19.4\end{array}$ & $\begin{array}{l}273.181 .5 \\
196.742 .7 \\
469.924 .2\end{array}$ & $\begin{array}{r}6.4 \\
166.7 \\
173.1\end{array}$ & $\begin{array}{r}3.2 \\
25.5 \\
28.7\end{array}$ & $\begin{array}{r}12.9 \\
502.3 \\
515.1\end{array}$ & $\begin{array}{r}12.9 \\
125.0 \\
137.8\end{array}$ & $\begin{array}{r}35.4 \\
263.9 \\
299.2\end{array}$ \\
\hline LEWIS & $\begin{array}{l}\text { RES } \\
\text { COI: } \\
\text { TOT }\end{array}$ & $\begin{array}{l}1.6 \\
5.8 \\
7.4\end{array}$ & $\begin{array}{r}135.507 .0 \\
70,127.5 \\
205,634.5\end{array}$ & $\begin{array}{r}3.2 \\
59.4 \\
62.6\end{array}$ & $\begin{array}{r}1.6 \\
9.1 \\
10.7\end{array}$ & $\begin{array}{r}6.4 \\
179.0 \\
185.4\end{array}$ & $\begin{array}{r}6.4 \\
44.6 \\
50.9\end{array}$ & $\begin{array}{r}17.5 \\
94.1 \\
111.6\end{array}$ \\
\hline MONTGCOMERY & $\begin{array}{l}\text { RES } \\
\text { CON } \\
\text { TOT }\end{array}$ & $\begin{array}{l}1.5 \\
8.2 \\
9.7\end{array}$ & $\begin{array}{r}130.653 .5 \\
99.631 .9 \\
230.285 .4\end{array}$ & $\begin{array}{r}3.1 \\
84.4 \\
87.5\end{array}$ & $\begin{array}{l}1.5 \\
12.9 \\
14.4\end{array}$ & $\begin{array}{r}6.1 \\
254.4 \\
260.5\end{array}$ & $\begin{array}{r}6.1 \\
63.3 \\
69.4\end{array}$ & $\begin{array}{l}16.9 \\
133.6 \\
150.5\end{array}$ \\
\hline NIAGARA & $\begin{array}{l}\text { RES } \\
\text { COR: } \\
\text { TOT }\end{array}$ & $\begin{array}{r}7.3 \\
38.6 \\
45.9\end{array}$ & $\begin{array}{r}618.570 .5 \\
468.448 .6 \\
1.087 .019 .1\end{array}$ & $\begin{array}{r}14.6 \\
396.8 \\
411.4\end{array}$ & $\begin{array}{r}7.3 \\
60.6 \\
67.9\end{array}$ & $\begin{array}{r}29.1 \\
1.195 .9 \\
1.225 .0\end{array}$ & $\begin{array}{r}29.1 \\
297.6 \\
326.7\end{array}$ & $\begin{array}{r}80.1 \\
628.3 \\
708.3\end{array}$ \\
\hline ONE IDA & $\begin{array}{l}\text { RES } \\
\text { COM } \\
\text { TOT }\end{array}$ & $\begin{array}{r}8.1 \\
51.0 \\
59.1\end{array}$ & $\begin{array}{r}685.389 .0 \\
619.596 .5 \\
1.304 .985 .5\end{array}$ & $\begin{array}{r}16.1 \\
524.8 \\
541.0\end{array}$ & $\begin{array}{r}8.1 \\
80.2 \\
88.2\end{array}$ & $\begin{array}{r}32.3 \\
1.581 .8 \\
1.614 .0\end{array}$ & $\begin{array}{r}32.3 \\
393.6 \\
425.9\end{array}$ & $\begin{array}{r}88.7 \\
831.0 \\
919.7\end{array}$ \\
\hline ONONDAGA & $\begin{array}{l}\text { RES } \\
\text { COM } \\
\text { TOT }\end{array}$ & $\begin{array}{r}1+.6 \\
16.2 \\
20.7\end{array}$ & $\begin{array}{l}387.515 .0 \\
196.407 .8 \\
583.922 .8\end{array}$ & $\begin{array}{r}9.1 \\
166.4 \\
175.5\end{array}$ & $\begin{array}{r}4.6 \\
25.4 \\
30.0\end{array}$ & $\begin{array}{r}18.2 \\
501.4 \\
519.7\end{array}$ & $\begin{array}{r}18.2 \\
124.8 \\
143.0\end{array}$ & $\begin{array}{r}50.1 \\
263.4 \\
313.6\end{array}$ \\
\hline ORLEANS & $\begin{array}{l}\text { REC } \\
\text { COM } \\
\text { TOT }\end{array}$ & $\begin{array}{l}1.4 \\
6.6 \\
8.0\end{array}$ & $\begin{array}{r}117.223 .5 \\
80.532 .4 \\
197.755 .9\end{array}$ & $\begin{array}{r}2.8 \\
68.2 \\
71.0\end{array}$ & $\begin{array}{l}1.4 \\
10.4 \\
11.8\end{array}$ & $\begin{array}{r}5.5 \\
205.6 \\
211.1\end{array}$ & $\begin{array}{r}5.5 \\
51.2 \\
56.7\end{array}$ & $\begin{array}{r}15.2 \\
108.0 \\
123.2\end{array}$ \\
\hline OSẈEGO & $\begin{array}{l}\text { RES } \\
\text { COM } \\
\text { TOT }\end{array}$ & $\begin{array}{l}2.7 \\
16.7 \\
19.3\end{array}$ & $\begin{array}{l}227,485.5 \\
202,188.6 \\
429,674.2\end{array}$ & $\begin{array}{r}5.4 \\
171.3 \\
176.6\end{array}$ & $\begin{array}{r}2.7 \\
26.2 \\
28.8\end{array}$ & $\begin{array}{r}10.7 \\
516.2 \\
526.9\end{array}$ & $\begin{array}{r}10.7 \\
128.4 \\
139.2\end{array}$ & $\begin{array}{r}29.4 \\
271.2 \\
300.6\end{array}$ \\
\hline RENSSELAER & $\begin{array}{l}\text { RES } \\
\text { COM } \\
\text { TOT }\end{array}$ & $\begin{array}{r}5.2 \\
25.5 \\
30.7\end{array}$ & $\begin{array}{l}438.005 .0 \\
309,693.3 \\
747.698 .3\end{array}$ & $\begin{array}{r}10.3 \\
262.3 \\
272.6\end{array}$ & $\begin{array}{r}5.2 \\
40.1 \\
45.2\end{array}$ & $\begin{array}{r}20.6 \\
790.6 \\
811.2\end{array}$ & $\begin{array}{r}20.6 \\
196.7 \\
217.4\end{array}$ & $\begin{array}{r}56.7 \\
115.4 \\
172.0\end{array}$ \\
\hline SARATOGA & $\begin{array}{l}\text { RES } \\
\text { COM } \\
\text { TOT }\end{array}$ & $\begin{array}{r}4.6 \\
23.3 \\
27.9\end{array}$ & $\begin{array}{l}392.904 .0 \\
282.704 .9 \\
675.608 .9\end{array}$ & $\begin{array}{r}9.2 \\
239.5 \\
248.7\end{array}$ & $\begin{array}{r}4.6 \\
36.6 \\
41.2\end{array}$ & $\begin{array}{r}18.5 \\
721.7 \\
740.2\end{array}$ & $\begin{array}{r}18.5 \\
179.6 \\
198.1\end{array}$ & $\begin{array}{r}50.8 \\
379.2 \\
430.0\end{array}$ \\
\hline SCHENECTADY & $\begin{array}{l}\text { RES } \\
\text { COM } \\
\text { TOT }\end{array}$ & $\begin{array}{r}4.5 \\
24.9 \\
29.4\end{array}$ & $\begin{array}{l}384.650 .5 \\
301.971 .9 \\
686.622 .4\end{array}$ & $\begin{array}{r}9.1 \\
255.8 \\
264.8\end{array}$ & $\begin{array}{r}4.5 \\
39.1 \\
43.6\end{array}$ & $\begin{array}{r}18.1 \\
770.9 \\
789.0\end{array}$ & $\begin{array}{r}18.1 \\
191.8 \\
209.9\end{array}$ & $\begin{array}{r}49.8 \\
405.0 \\
454.8\end{array}$ \\
\hline SCHOHARIE & $\begin{array}{l}\text { RES } \\
\text { COM } \\
\text { TOT }\end{array}$ & $\begin{array}{l}1.7 \\
6.0 \\
7.6\end{array}$ & $\begin{array}{r}141.669 .5 \\
72.586 .6 \\
214.256 .1\end{array}$ & $\begin{array}{r}3.3 \\
61.5 \\
64.8\end{array}$ & $\begin{array}{r}1.7 \\
9.4 \\
11.1\end{array}$ & $\begin{array}{r}6.7 \\
185.3 \\
192.0\end{array}$ & $\begin{array}{r}6.7 \\
46.1 \\
52.8\end{array}$ & $\begin{array}{r}18.3 \\
97.4 \\
115.7\end{array}$ \\
\hline ST. LAWRENCE. & $\begin{array}{l}\text { RES } \\
\text { COM } \\
\text { TOT }\end{array}$ & $\begin{array}{r}5.5 \\
26.4 \\
31.9\end{array}$ & $\begin{array}{l}467.381 .0 \\
319.989 .3 \\
787,370.3\end{array}$ & $\begin{array}{r}11.0 \\
271.0 \\
282.0\end{array}$ & $\begin{array}{r}5.5 \\
41.4 \\
46.9\end{array}$ & $\begin{array}{r}22.0 \\
816.9 \\
838.9\end{array}$ & $\begin{array}{r}22.0 \\
203.3 \\
225.3\end{array}$ & $\begin{array}{r}60.5 \\
429.2 \\
489.6\end{array}$ \\
\hline
\end{tabular}


COUNTY

ALLEGANif

BROOHE

CAYUGA

CHEMUNG

CHENANGO

品

\section{DELAWAFE}

LIVINGSION

MADISON

OTSEGO

SCHUYLER

SENECA

STEUBEN
ALDEHYDES

RES
COM

TOT

RES

TOT

RES

COM

TOT

RES

COM

RES

COM

RES

COM

TOT

RES

TOT

RES

COM

TOT

RES
COM

TOT

RES

COM

RES

COM

RES

11.2
12.9

0.8
2.7

2.7
3.6

12.0

9.0
10.4

2.2
12.1
14.3

12.2
15.2

0.6

0.6
3.0

0.8
5.0

5.8
NYSE +G CARBON DIOX

$39,074.5$
19.397 .0
$58,471.5$

335.716 .0

$355,895.8$

143.259 .0

$136,125.0$

$136,125.0$
$279,384.0$

71.731 .5

33.269 .9
105.001 .4

203.541 .0

118.316 .6

$12.1 \quad 321.857 .6$

2.4 207.349 .0

$3.6 \quad 116.539 .3$

323.888 .3

$121,898.5$

230.999 .4

183.557 .5

147.253 .1

330.810 .7

253.614 .5

$148,194.1$
$401,808.6$

49.172 .5

35.858 .9

$85,031.4$

$65,407.5$

61.123 .5

126.531 .0

156.587 .0
CARBON MONO HYDRO CARBON NITROGEN OXIDE

0.9

16.4
17.3

0.5
2.5
3.0

7.9
301.5

301.5
309.4

3.4

115.3

118.7

1.7
28.2

28.2
29.9

4.8

100.2

105.0

4.9

98.7
103.6

2.9

92.4
95.3

4.3

4.3
124.7

124.7
129.1

6.0
125.5

131.5

1.2
30.4

30.4
31.5

1.5
51.8

51.8
53.3

3.7
1.8

49.5

51.4

15.8
908.6

3.9
46.1

50.0

1.7

17.6

19.3

0.8
4.3

4.3
5.1

2.4
15.3

17.7

2.4
15.1

15.1
17.5

1.4
14.1

15.6

2. 2

3.0

19.2
22.2

0.6

4.6
5.2

0.8

7.9

8.7

1. 8
19.1
21.2
921.4

6.7

347.5

354.3

3.4
84.9

84.9
88.3

9.6

302.1

9.8

9.8
297.5

307.3

5.7
278.5

$2 B^{\prime} .3$

8.6

8.6
375.9

384.6

11.9

378.3
390.3

2.3

91.5

3.1

156.0
159.1

7.4
PART ICULATES SULFUR DIOXIDE

1.8

$14.2 \quad 31.1$

15.8
226.1

241.9

6.7

86.5

93.2

3.4

21.1
24.5

31.1

43.4
477.3

520.8

18.5

182.6

201.1

9.3
44.6

53.9

9.6
75.2

84.7

26.3
158.7

158.7

185.0

9.8

74.0
83.8

26.8

56.3

183.1

5.7
69.3

69.3
75.0

15.8
146.3

162.1

8.6

93.5

93.5
102.2

23.8

97.5

11.9

94.1
106.1

32.8

198.6
231.6

ว. 3

टर.

ट5. 1

3.1

38.8
41.9

7.4
6.4

48.1 54.5

8.5
82.0

90.4

20.3 


\begin{tabular}{|c|c|c|c|c|c|c|c|c|}
\hline . & $\begin{array}{l}\text { COM } \\
\text { TOT }\end{array}$ & $\begin{array}{l}12.5 \\
14.4\end{array}$ & $\begin{array}{l}152.363 .3 \\
308.950 .4\end{array}$ & $\begin{array}{l}129.1 \\
132.7\end{array}$ & $\begin{array}{l}19.7 \\
21.6\end{array}$ & $\begin{array}{l}389.5 \\
396.5\end{array}$ & $\begin{array}{r}96.8 \\
104.2\end{array}$ & $\begin{array}{l}204.3 \\
224.6\end{array}$ \\
\hline SULLIVAN & $\begin{array}{l}\text { RES } \\
\text { COM } \\
\text { TOT }\end{array}$ & $\begin{array}{r}14.1 \\
13.8 \\
17.9\end{array}$ & $\begin{array}{l}346.664 .0 \\
167.351 .4 \\
514.015 .4\end{array}$ & $\begin{array}{r}8.2 \\
141.8 \\
149.9\end{array}$ & $\begin{array}{r}4.1 \\
21.7 \\
25.7\end{array}$ & $\begin{array}{r}16.3 \\
427.2 \\
143.6\end{array}$ & $\begin{array}{r}16.3 \\
106.3 \\
122.6\end{array}$ & $\begin{array}{r}41.9 \\
221.4 \\
269.3\end{array}$ \\
\hline TIOGA & $\begin{array}{l}\text { RES } \\
\text { COM } \\
\text { TOT }\end{array}$ & $\begin{array}{r}2.1 \\
9.4 \\
11.5\end{array}$ & $\begin{array}{l}180,786.5 \\
114,297.8 \\
295,084.3\end{array}$ & $\begin{array}{r}4.3 \\
96.8 \\
101.1\end{array}$ & $\begin{array}{r}2.1 \\
14.8 \\
16.9\end{array}$ & $\begin{array}{r}8.5 \\
291.8 \\
300.3\end{array}$ & $\begin{array}{r}8.5 \\
72.6 \\
81.1\end{array}$ & $\begin{array}{r}23.4 \\
153.3 \\
176.7\end{array}$ \\
\hline TOMPK INS & $\begin{array}{l}\text { RES } \\
\text { COM } \\
\text { TOT }\end{array}$ & $\begin{array}{r}1 .+ \\
11.5 \\
13.5\end{array}$ & $\begin{array}{l}119.450 .5 \\
140.673 .3 \\
260.123 .8\end{array}$ & $\begin{array}{r}2.8 \\
119.2 \\
122.0\end{array}$ & $\begin{array}{r}1.4 \\
18.2 \\
19.6\end{array}$ & $\begin{array}{r}5.6 \\
.359 . . \\
364.8\end{array}$ & $\begin{array}{r}5.6 \\
89.4 \\
95.0\end{array}$ & $\begin{array}{r}15.5 \\
188.7 \\
204.1\end{array}$ \\
\hline WYOMING & $\begin{array}{l}\text { RES } \\
\text { COM } \\
\text { TOT }\end{array}$ & $\begin{array}{l}0.7 \\
5.0 \\
5.7\end{array}$ & $\begin{array}{r}57.638 .5 \\
60,857.5 \\
118.495 .9\end{array}$ & $\begin{array}{r}1.4 \\
51.5 \\
52.9\end{array}$ & $\begin{array}{l}0.7 \\
7.9 \\
8.6\end{array}$ & $\begin{array}{r}2.7 \\
155.4 \\
158.1\end{array}$ & $\begin{array}{r}2.7 \\
38.7 \\
41.4\end{array}$ & $\begin{array}{r}7.5 \\
81.6 \\
89.1\end{array}$ \\
\hline YATES & $\begin{array}{l}\text { RES } \\
\text { COM } \\
\text { TOT }\end{array}$ & $\begin{array}{l}0.7 \\
3.5 \\
4.2\end{array}$ & $\begin{array}{l}56,542.0 \\
42,860.4 \\
99,402.4\end{array}$ & $\begin{array}{r}1.3 \\
36.3 \\
37.6\end{array}$ & $\begin{array}{l}0.7 \\
5.5 \\
6 . \bar{\varepsilon}\end{array}$ & $\begin{array}{r}2.7 \\
109.1 \\
112.1\end{array}$ & $\begin{array}{r}2.7 \\
27.2 \\
29.9\end{array}$ & $\begin{array}{r}7.3 \\
57.5 \\
64.8\end{array}$ \\
\hline TOTAL & & 191.9 & $4.551,467.8$ & 1.720 .8 & 284.1 & 5.124 .4 & 1.366 .8 & 2.963 .4 \\
\hline
\end{tabular}

*RESCOM POLI_ UTILITY CORANGE +FOOCKL AND I\%

POLLUTION FROM ZESIDENTIAL AND COMMERCIAL OIL CONSUMPTION

FOR NEWI YORF: STATE $1976(1000$ TONS $)$

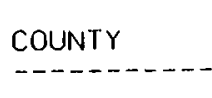

ORANGE

ROCKLAND

TOTAL
ORANGE +ROCKLAND

ORANGE +ROCKLAND
ALDEHYDES CARBON DIOX CARBJN MONO HYDRO CARBON NITROGEH OXIDE

RES
COM
TOT
RES
COM
TOT

8.
40.
48.

8.1
40.8
48.9

487.641 .5

$435,220.2$
$.182,861.7$

$\begin{array}{rr}1.2 & 102.637 .5 \\ 4.4 & 53.57 .1 .3 \\ 5.6 & 156.208 .8\end{array}$

$54.5 \quad 1.339,070.4$

16.2
419.5
435.7
2.4
45.4
47.8

\subsection{1}

72.2

1.2

8.1

80.3
32.4
1. 264.3
1.296 .6

4.8

136.8

111.6

$1,438.2$

\section{PARTICULATES SULFUR DIOXIDE}

32.4 $314.6 \quad 89.0$

$\begin{array}{ll}314.6 & 664.2 \\ 347.0 & 753.2\end{array}$

4.8

34.0

38.9

385.8
13.3

71.8

85.1

838. 3 
-RESCOM POLL UTILITY RIOT+EI\%

STEUBEN

MONROE

ONTARIO

WAYNE

TOTAL
RES
LOM

1.8
12.5 $\begin{array}{llrlr}.8 & 156,587.0 & 3.7 & 1.8 & 7.4 \\ .5 & 152,363.3 & 129.1 & 19.7 & 389.0 \\ \text { POLLUT ION FROM RESIDENT IAL AND COMMERC IAL OIL CONSUMPIION } \\ \text { FOR NEW YORK STATE } & \text { I976 } & 11000 \text { TONS I }\end{array}$

7.4
96.8

20.3

204.3
RG + E
ALDEHYDES CARBON DIOX CARBON DIOX

$\begin{array}{rr}12.8 & 1,089,011.5 \\ 95.2 & 155,694.0 \\ 108.0 & \quad=.244 .705 .5\end{array}$

CARBON MONO

HYORO CARBON NITROGEN OXIDE

RES
COM
TOT

RES

COM

COM

RES

COM
TOT

108.0

HYORO CARBON

N

$\begin{array}{rrr}12.8 & 1.089 .011 .5 & 25.6 \\ 95.2 & 1.155 .694 .0 & 978.9 \\ 108.0 & 2.244 .705 .5 & 1.004 .6 \\ 1.8 & 155.771 .0 & 3.7 \\ 12.4 & 150.919 .2 & 127.8 \\ 14.3 & 306.690 .2 & 131.5 \\ 2.4 & 208.165 .0 & \\ 13.4 & 162.452 .0 & 137.6 \\ 15.8 & 370.617 .0 & 142.5 \\ 138.1 & 2.922 .012 .7 & 1.278 .6\end{array}$

12.8
149.6
162.4
1.8
19.5
21.4
2.4
21.0
23.5
207.2

\section{PARTICULATES SULFUR DIOXIDE \\ PARTICULATES SULFUR DIOXIDE}

51.2
734.2
785.5
7.3
95.9
103.2
9.8
103.2
113.0
001.7

140.9

$\begin{array}{rrr}51.2 & 51.2 & 140.9 \\ 2.950 .4 & 734.2 & 1.550 .0\end{array}$

$\begin{array}{lll}2.950 .4 & 734.2 & 1.550 .0 \\ 3.001 .7 & 785.5 & 1,690.9\end{array}$

7.3

385.3

392.6

9.8
414.7

424.5

3.818 .8

20.2

203.4

202.4
222.6

26.9
217.9 244.8

$1.001 .7 \quad 2.158 .3$


"TYPICAL BILLS(INCUSTRIALIX

TYFICAL-BILLS--INDUSTRI.AL-AS OF JAN. 11977

\begin{tabular}{|c|c|c|c|c|c|c|c|c|c|c|c|c|c|}
\hline UTILITY & COMMUNITY & SCHEO & TYPE & $\begin{array}{l}75 \mathrm{KW} \\
15 E 3 \mathrm{KLHH}\end{array}$ & $\begin{array}{l}75 \mathrm{KN} \\
3 E 5 \mathrm{KW-1}\end{array}$ & $\begin{array}{l}150 \mathrm{KW} \\
\text { 3E5KWH }\end{array}$ & $\begin{array}{l}150 \mathrm{KW} \\
6 E 5 \mathrm{KLNH}\end{array}$ & $\begin{array}{l}300 K W \\
6 E 5 K L N H\end{array}$ & $\begin{array}{l}300 K W \\
12 E 5 K I N H\end{array}$ & $\begin{array}{l}500 K W \\
\text { IEIGKWH }\end{array}$ & $\begin{array}{l}600 K W \\
\text { IE6 KWH }\end{array}$ & $\begin{array}{l}\text { IE 3KW } \\
\text { IEG KWH }\end{array}$ & $\begin{array}{l}\text { IE. 3KW } \\
\text { LEG KWIT }\end{array}$ \\
\hline CON ED & $N Y C$ & $\begin{array}{l}\text { SC-9 } \\
\text { SUMM }\end{array}$ & MUL & 51410 & $\$ 2087$ & \$2820. & $\$ 4173$. & $\$ 5641$ & $\$ 8347$ & $\$ S^{1}+01$ & $\$ 13911$. & $\$ 18802$. & \$27822. \\
\hline & $N Y C$ & $\begin{array}{l}\text { SC-9 } \\
\text { WINT }\end{array}$ & MUL & S.1362. & $\$ 2039$ & $\$ 2725$. & $\$ 4078$ & $\$ 5450$. & $\$ 8156$ & $\$ \subseteq 083$ & $\$ 13593$. & \$18I66. & $\$ 27186$ \\
\hline & $\begin{array}{l}\text { WHI TE PLA } \\
\text { INS }\end{array}$ & $\begin{array}{l}\text { SC-9 } \\
\text { SUMM }\end{array}$ & MUL & 51392. & $\$ 2060$ & $\$ 2784$ & $\$ 4120$ & $\$ 5569$. & $\$ 8241$ & $\$ \subset 282$ & $\$ 137314$ & $\$ 18563$ & $\$ 27468$ \\
\hline & $\begin{array}{l}\text { WHIITE PLA } \\
\text { INS }\end{array}$ & $\begin{array}{l}\text { SC-9 } \\
\text { WINT }\end{array}$ & MUL. & 51345. & $\$ 2013$ & $\$ 2690$. & $\$ 4026$ & $\$ 5380$ & $\$ 8052$ & TE967 . & $\$ 13420$ & \$17935. & $\$ 268^{4}+0$ \\
\hline LILCO & LEVITTOWN & $\begin{array}{l}S C-2- \\
L\end{array}$ & MUL - & $\$ 839$. & $\$ 1 \leq 86$ & $\$ 1647$. & $\$ 2586$. & $\$ 3080$ & $\$ 4957$. & \$E021 & $\$ 8149$ & $\$ 9872$ & $\$ 16128$ \\
\hline $\begin{array}{l}\text { NI AGARA } \\
\text { MOHAWK }\end{array}$ & BUFF ALO & $\begin{array}{l}\text { 3-PSC } \\
-207\end{array}$ & MUL & $\$ 693$. & $\$ \subseteq 65$. & $\$ 1197$. & $\$ 1740$ & $\$ 2 ! 97$ & $\$ 3284$ & $\$ 3487$ & \$5298. & $\$ 6710$ & $\$ 10332$. \\
\hline & SYRACUSE & $\begin{array}{l}\text { 3-PSE } \\
-207\end{array}$ & MUL & $\$ 693$. & \$565. & $\$ 1197$. & $\$ 1740$ & $\$ 2197$ & $\$ 3284$ & $\$ \Xi 487$ & \$5298. & $\$ 6710$ & \$10332: \\
\hline & UTICA & $\begin{array}{l}3-P S E \\
-207\end{array}$ & MUL & $\$ 693$. & $\$ 965$. & $\$ 1197$. & $\$ 1740$ & $\$ 219 \%$ & 93284 & $\$ 3187$. & \$5298. & $\$ 6710$ & \$10332. \\
\hline$N Y S E+G$ & $\begin{array}{l}\text { BINGHAMTO } \\
N\end{array}$ & $\begin{array}{l}\text { SC } 30 S \\
\text { C } 115\end{array}$ & MUL & $\$ 627$. & $\$ 899$. &.$\$ 1149$ & $\$ 1673$ & \$2।I. & $\$ 3205$ & $\Phi 3388$ & \$5211. & $\$ 6578$ & $\$ 10225$. \\
\hline & $\begin{array}{l}\text { BINGHAMTO } \\
\mathrm{N}\end{array}$ & $\begin{array}{l}\text { SC2PE } \\
\text { C115 }\end{array}$ & MUL & $\$ 630$ & $\$ 935$. & $\$ 1203$ & $\$ 1760$ & $\$ 2111$. & $\$ 3205$ & $\$ \Xi 388$. & $\$ 5211$. & $\$ 6578$. & £10225. \\
\hline & CHEEKTOWA & $\begin{array}{l}\text { SC2PS } \\
\text { C115 }\end{array}$ & MUL & $\$ 630$. & $\$ 935$. & $\$ 1203$. & $\$ 1760$. & \$2।11. & $\$ 3205$ & $\$ 3388$ & \$5211. & $\$ 6578$ & \$10225. \\
\hline & $\begin{array}{l}\text { CHEEKTOWA } \\
\text { GA }\end{array}$ & $\begin{array}{l}\text { SC 3P: } \\
\text { C115 }\end{array}$ & MUL & $\$ 627$. & \$96E. & $\$ 1197$. & $\$ 1704$. & $\$ 2197$. & $\$ 3284$ & $\$ 3487$ & \$5298. & $\$ 67 ! 0$ & \$10332. \\
\hline$R G+E$ & $\begin{array}{l}\text { IRONDEQUO } \\
\text { IT TWIN } \\
\text { ROCHESTER }\end{array}$ & $\begin{array}{l}S C-3 \\
S C-3\end{array}$ & MUL & $\begin{array}{l}\$ 747 . \\
\$ 747\end{array}$ & $\begin{array}{l}\$ 1021 . \\
\$ 1021:\end{array}$ & $\begin{array}{l}\$ 1257 \\
\$ 1257\end{array}$ & $\begin{array}{l}\$ 1805 . \\
\$ 1805 .\end{array}$ & $\begin{array}{l}\$ 2491 . \\
\$ 2491 .\end{array}$ & $\begin{array}{l}\$ 3575 . \\
\$ 35 / 5 .\end{array}$ & $\begin{array}{l}\text { qL } 165 . \\
\text { qL } 165 .\end{array}$ & $\begin{array}{l}\$ 5973 . \\
\$ 5973 .\end{array}$ & $\begin{array}{l}\$ 7753 . \\
\$ 7753 .\end{array}$ & $\begin{array}{l}\$ 11368 . \\
\$ 11368 .\end{array}$ \\
\hline
\end{tabular}


TYPICAL ELECTRICITY BILLS-RESIDENTIAL-AS OF JAN. I 1977

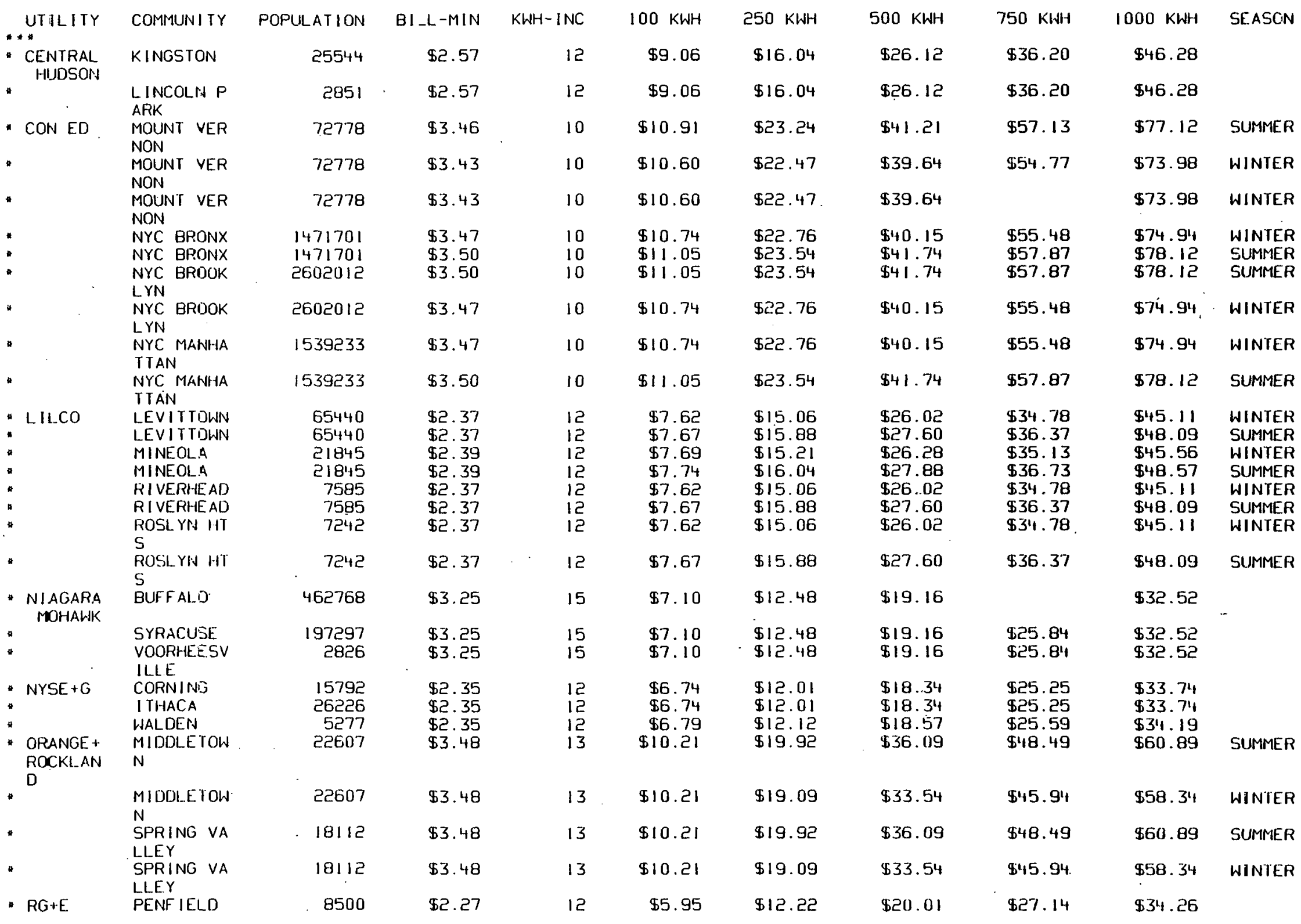


$\begin{array}{lllllllll}\text { ROCHESTER } & 296233 & \$ 2.27 & 12 & \$ 5.95 & \$ 12.22 & \$ 20.01 & \$ 27.14 & \$ 34.26\end{array}$

- typical billosicomiercial ix
NYC BROOK
2602015
13.47
10
$\$ 10.74$
\$22. 76
$\$ 40.15$
$\$ 53.48$
$\$ 74.914$
WINTER

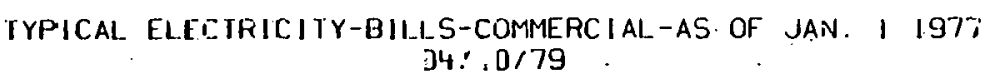

\begin{tabular}{|c|c|c|c|}
\hline UTILITY & COMMUNITY & SCH CESIGN & TYPE \\
\hline CON EO & $\begin{array}{lll}N & Y & C \\
N & Y & C\end{array}$ & $\begin{array}{l}S C-2.9 \text { SUM } \\
5 C-2.9 \text { WIN }\end{array}$ & $\begin{array}{l}\text { GEN } \\
\text { GEN }\end{array}$ \\
\hline & $\begin{array}{l}\text { WHII TE PI_A } \\
\text { INS }\end{array}$ & SC-2. 9 SUM & GEN \\
\hline & $\begin{array}{l}\text { WHI TE PLA } \\
\text { INS }\end{array}$ & SC-2, $\exists$ WIN & GEN \\
\hline LILCO & $\begin{array}{l}\text { LEVIT TOWN } \\
\text { LEVIT TOWN }\end{array}$ & $\begin{array}{l}\text { SC-2 SUMM } \\
\text { SC-2 WINT }\end{array}$ & $\begin{array}{l}\text { GEN } \\
\text { GEN }\end{array}$ \\
\hline $\begin{array}{l}\text { NIAGARA } \\
\text { MOHAWKK }\end{array}$ & BUFFALO & $2-P S C-5 G 7$ & GEN \\
\hline & SYRACUSE & 2-PSC-207 & GEN \\
\hline & UTICA. & $2-P S C-2017$ & GEN \\
\hline$N Y S E+G$ & $\underset{N}{B \text { INGIIAMTO }}$ & SC2PSC 115 & GEN \\
\hline & $\begin{array}{l}\text { CHEEKTOWA } \\
\text { GA }\end{array}$ & SC2PSC 115 & GEN \\
\hline$R G+E$ & $\begin{array}{l}\text { IRONDEQUO } \\
\text { IT TWN } \\
\text { ROCHIESTER }\end{array}$ & S.C. NO.7 & GEN \\
\hline
\end{tabular}

YPE OF SERVICE

$375 \mathrm{KWH}-3 \mathrm{KW}$

$\$ 40.02$

$\$ 38.82$

$\$ 39.51$

$\$ 38.33$

$\$ 23.55$

$\$ 21.84$

\$25. 50

$\$ \geq 2.20$
$\$ \geq 2.50$

$\$ 22.20$
$\$ 19.20$

$\$ 19.20$

$\$ 31.21$

$\$ 31.21$
$1500 \mathrm{KWH}-12 \mathrm{KW}$

\$189. 214 $\$ 181.60$

$\$ 186.83$

$\$ 179.29$

$\$ 88.15$

$\$ 79.96$

$\$ 75.02$

$\$ 75.05$

$\$ 75.05$
$\$ 77.37$

$\$ 77.37$

$\$ 95.68$

$\$ 95.68$
$6000 \mathrm{KWH}-30 \mathrm{KW} \quad 10000 \mathrm{KWH}-40$

$\begin{array}{ll}\$ 574.57 & \$ 856 . \\ \$ 555.48 & \$ 830 . \\ \$ 567.26 & \$ 845 . \\ \$ 548.41 & \$ 820 . \\ \$ 351.66 & \$ 533 . \\ \$ 351.66 & \$ 533 . \\ \$ 273.42 & \$ 428 . \\ \$ 273.42 & \$ 428 . \\ \$ 273.42 & \$ 428 . \\ \$ 263.54 & \$ 409 . \\ \$ 263.54 & \$ 409 . \\ \$ 315.78 & \$ 459 . \\ \$ 315.78 & \$ 459 .\end{array}$


"PCWER PLANT CONS (CENTRAL HUDSON) $\%$

POWER PLANT FUEL CONSUMPTION-1976 $04 / 10 / 79$

\begin{tabular}{|c|c|c|c|c|c|c|c|c|}
\hline FOWER PLANTT & COUNTY & $\begin{array}{l}\text { COAL } \\
1000 \text { TONS }\end{array}$ & $\begin{array}{l}\text { COAL } \\
\text { IES BTU }\end{array}$ & $\begin{array}{l}\text { GAS } \\
\text { MMCF }\end{array}$ & $\begin{array}{l}\text { GAS } \\
\text { IES BTU }\end{array}$ & $\begin{array}{l}01 \mathrm{~L} \\
1000\end{array}$ & BARRELS & $\begin{array}{l}\text { OIL } \\
\text { IES BTU }\end{array}$ \\
\hline $\begin{array}{l}\text { COXSACKIE } \\
\text { OANSKAMMER } \\
\text { OASHVILLE } \\
\text { NEVERSINK. }\end{array}$ & $\begin{array}{l}\text { GREENE } \\
\text { ORANGE } \\
\text { ULSTER } \\
\text { SULLIVA } \\
N\end{array}$ & & & & & & 3679 & 23067 \\
\hline $\begin{array}{l}\text { ROSETON } \\
\text { SO. CAIRO } \\
\text { STURGEON }\end{array}$ & $\begin{array}{l}\text { ORANGE } \\
\text { GREENE } \\
\text { ULSTER }\end{array}$ & & . & & & & $162 \mid$ & 10164 \\
\hline
\end{tabular}

"POWER PLANT CONS(CITY DF JAMESTOWN) $\%$

POHER PLANT FUEL CONSUMPTION-1976

POHER PLANT $04 / 10 / 79$
0

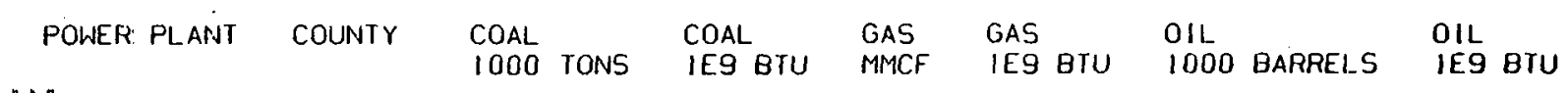

- COXSACKIE
OANSKAMMER
OASHVILLE
MEVERSINK
ROSETON
SO. CAIRO
STURGEON
POWER PLANT CONS
POWER PLANT
" S.A. CARLSO
N

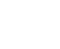

(1)

"POWER PLANT CONS(CITY OF PLATTSBURGH)

POWER PLANT FUEL CONSUMPTION-1976

$04 / 10 / 79$

\begin{tabular}{|c|c|c|c|c|c|c|c|c|}
\hline POWER PLANT & COUNTY & $\begin{array}{l}\text { COAL } \\
1000\end{array}$ & TONS & $\begin{array}{l}\text { COAL } \\
\text { IEG BTU. }\end{array}$ & $\begin{array}{l}\text { GAS } \\
\text { MMCF }\end{array}$ & $\begin{array}{l}\text { GAS } \\
\text { IES BTU }\end{array}$ & $\begin{array}{l}\text { OIL } \\
1000 \text { BARRELS }\end{array}$ & $\begin{array}{l}\text { OIL } \\
\text { IES BTU }\end{array}$ \\
\hline
\end{tabular}

* dIESE. 
- POWER P_ANT CONG(COV E.DIX

POAER PLANT FUEL CONSUMPIION-1976 D4 $10 / 79$

\begin{tabular}{|c|c|c|c|c|c|c|c|}
\hline POWER PLANT & COURITY & $\begin{array}{l}\text { COAL } \\
\text { IOOO TOMS }\end{array}$ & $\begin{array}{l}\text { COAL } \\
\text { IES BTU }\end{array}$ & $\begin{array}{l}\text { GAS } \\
\text { MMCF }\end{array}$ & $\begin{array}{l}\text { GAS } \\
\text { IES BTU }\end{array}$ & $\begin{array}{l}\text { OIL } \\
1000 \text { BARRELS }\end{array}$ & $\begin{array}{l}\text { OII } \\
\text { IES BTU }\end{array}$ \\
\hline * $59 \mathrm{ST}$ & NEW YOR & & & & & 1410 & 8841 \\
\hline $74 \mathrm{ST}$ & $\begin{array}{l}\text { NEWW YOR } \\
\text { KK }\end{array}$ & & & & & 630 & 3950 \\
\hline - ARTHIUF KIEL & $\begin{array}{l}\text { RICHMON: } \\
\text { D }\end{array}$ & & . & & & $5+79$ & 34353 \\
\hline $\begin{array}{l}\text { - aSTORI } \\
\text { - BOWL INE }\end{array}$ & $\begin{array}{l}\text { QUEENS } \\
\text { ROCKLAN\$ } \\
0\end{array}$ & & & $\begin{array}{r}382 \\
63\end{array}$ & $\begin{array}{r}390 \\
64\end{array}$ & $\begin{array}{r}10087 \\
5044\end{array}$ & $\begin{array}{l}63245 \\
31626\end{array}$ \\
\hline - EAST FIVER & $\underset{K}{N E W}$ YOR & & & 78 & 80 & 2275 & 14264 \\
\hline $\begin{array}{l}\text { " GOWANLIS } \\
\text { HUDSON AVEN } \\
\text { UE }\end{array}$ & $\begin{array}{l}\text { KINIES } \\
\text { KINES }\end{array}$ & & & & & $\begin{array}{l}947 \\
97: 1\end{array}$ & $\begin{array}{l}5938 \\
6107\end{array}$ \\
\hline - INDIAN POIN & $\begin{array}{l}\text { WES ICHE } \\
\text { STES: }\end{array}$ & & & & & 118 & 740 \\
\hline $\begin{array}{l}\text { * KENT AJE } \\
\text { * NARROW'S EAY }\end{array}$ & $\begin{array}{l}K ! N=S \\
\text { KIN=S }\end{array}$ & & & & & $\begin{array}{r}2 \\
7814\end{array}$ & $\begin{array}{r}13 \\
4316\end{array}$ \\
\hline - RAVENSHOCD & QUE $\equiv N S$ & & & 218 & 222 & 12747 & 79924 \\
\hline $\begin{array}{l}\text { ROSETIN } \\
\text { * WATERSIDE }\end{array}$ & $\begin{array}{l}\text { ORAYGG } \\
\text { NEW YOF }\end{array}$ & & & 1385 & 1413 & 2136 & 13330 \\
\hline
\end{tabular}


- power plant cons (LILCoix

PONER PLANT FUEL CONSUMPTION-1976 $04 / 10 / 79$

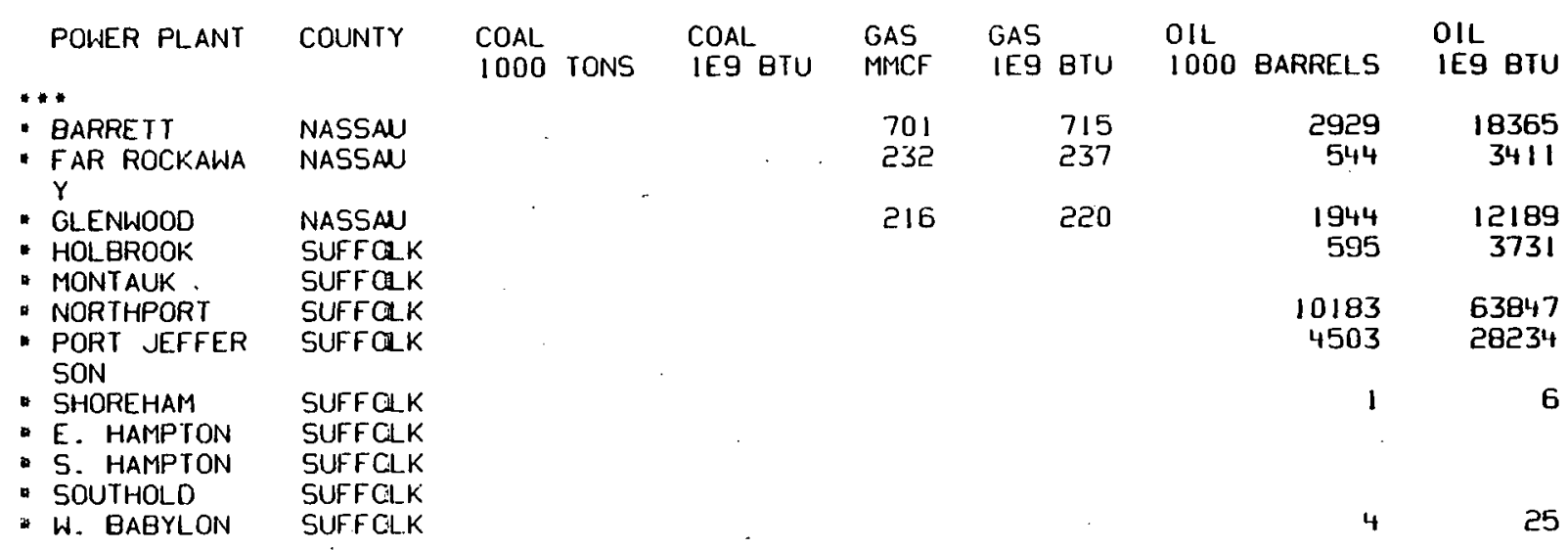


- power plant cons (n: agara mohaljkiz

$$
\begin{gathered}
\text { POWER PLANT FUEL CONSUMPTION-1976 } \\
04 / 10,79
\end{gathered}
$$

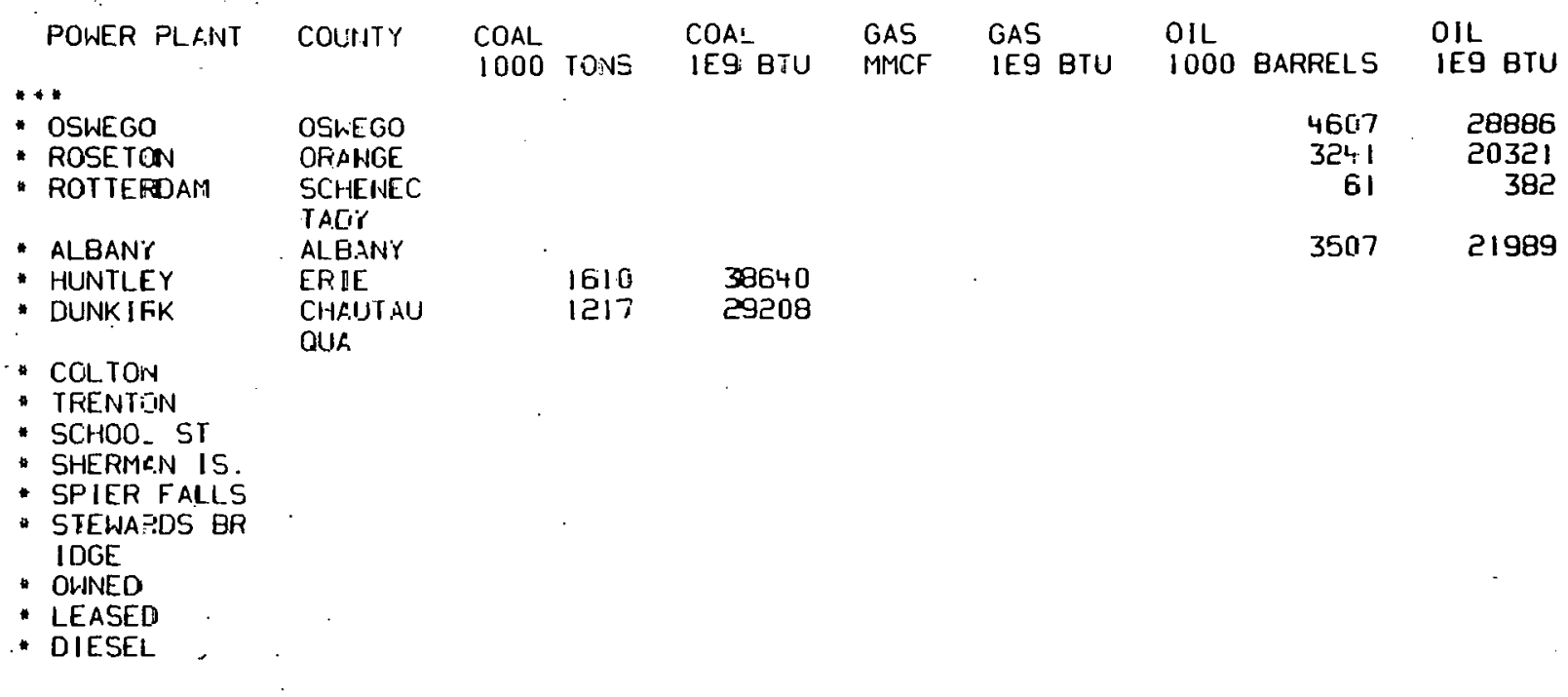

- PONER PL.AVT CONSINYSE+GI\%

FOWER PLANT FUEL CONSUMPTION-1976

$04 ; 10 / 79$

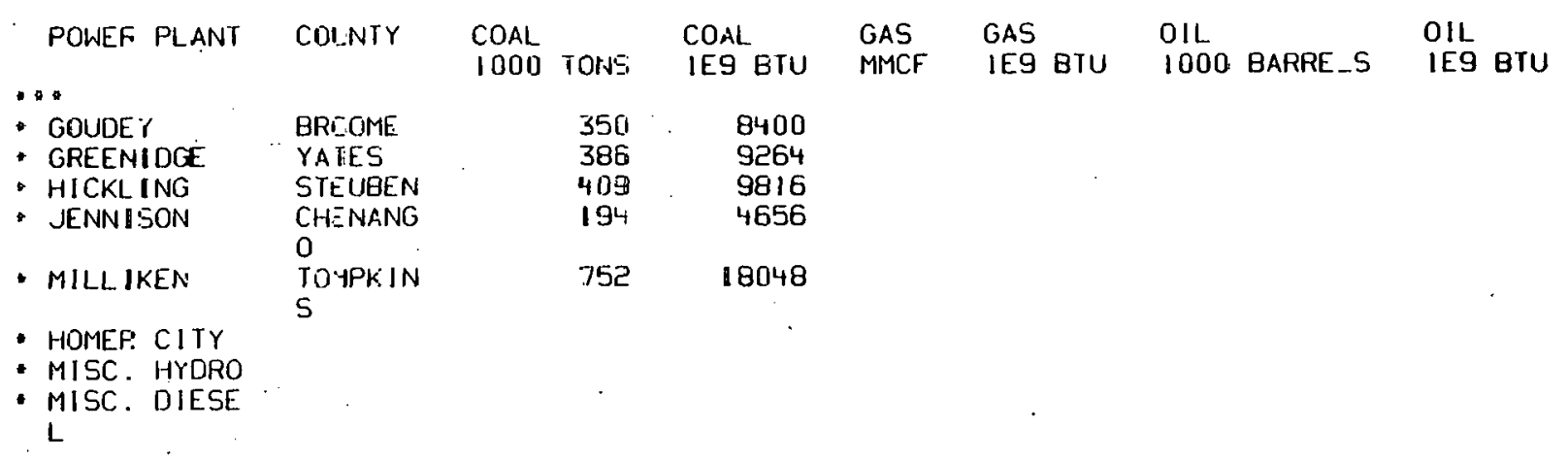


- POWER PLANT CONS (ORA VGE +ROCKLANDI\%

PONER PLANT FUEL CONSUMPTION-1976 $04 / 10 / 79$

\begin{tabular}{|c|c|c|c|c|c|c|c|}
\hline POWER PLANT & COUNTY & $\begin{array}{l}\text { COAL } \\
1000 \text { TONS }\end{array}$ & $\begin{array}{l}\text { COAL } \\
\text { IES BTU }\end{array}$ & $\begin{array}{l}\text { GAS } \\
\text { MMCF }\end{array}$ & $\begin{array}{l}\text { GAS } \\
\text { IES BTU }\end{array}$ & $\begin{array}{l}\text { OIL } \\
1000 \text { BARRELS }\end{array}$ & $\begin{array}{l}\text { OIL } \\
\text { IES BTU }\end{array}$ \\
\hline * HILLBURN & $\begin{array}{l}\text { ROCKLAN } \\
D\end{array}$ & & & & & 2 & 13 \\
\hline - LOVETT & $\begin{array}{l}\text { ROCKLAN } \\
\text { D }\end{array}$ & . & & 1878 & 1916 & 2417 & 15155 \\
\hline $\begin{array}{l}\text { - SHOEMAKER } \\
\text { - BOWL INE }\end{array}$ & $\begin{array}{l}\text { ORANG } \\
\text { ROCKLAN } \\
D\end{array}$ & & & 32 & 32 & $\begin{array}{r}2 \\
2525\end{array}$ & $\begin{array}{r}13 \\
15832\end{array}$ \\
\hline
\end{tabular}

- POWER plant consipasnyiz

PONNER PLANT FUEL CONSUMPTION-1976

$04 / 10 / 79$

$\begin{array}{llllll}\text { POWER PLANT COUNTY COAL } & \text { COAL } & \text { GAS GAS } & \text { OIL } & \text { OIL } \\ & 1000 \text { TONS IEG BIU MMCF IES BIU } 1000 \text { BARRELS IES BIU }\end{array}$

- MOSES NIAG.

LEWISTON

aUX. PUMPED

STORAGE

BLENHIEN GI

LBOA

- fitzPa.tRick

- indian poIN.

- MOSES POHER

DAM 
- PONER PLANT CONS (FG+E)\%

POLER PLANT FUEL CONSUMPTION-1976

$04 / 1 C / 79$

\begin{tabular}{|c|c|c|c|c|c|c|c|c|}
\hline POWEF: PLANT & COINITY & $\begin{array}{l}\text { COAL } \\
1000\end{array}$ & TONS & $\begin{array}{l}\text { COAL } \\
\text { IES BTU }\end{array}$ & $\begin{array}{l}\text { GAS } \\
\text { MMCF }\end{array}$ & $\begin{array}{l}\text { GAS } \\
\text { IES BTU }\end{array}$ & $\begin{array}{l}\text { OIL } \\
1000 \text { BARRELS }\end{array}$ & $\begin{array}{l}\text { OIL } \\
\text { IES BTU }\end{array}$ \\
\hline $\begin{array}{l}\mathrm{ROCH} 3 \\
\mathrm{ROCH} 7\end{array}$ & $\begin{array}{l}\text { MONROE } \\
\text { MOMROE }\end{array}$ & & $\begin{array}{l}197 \\
515\end{array}$ & $\begin{array}{r}4728 \\
12360\end{array}$ & & & $\begin{array}{r}930 \\
1\end{array}$ & $\begin{array}{r}5831 \\
6\end{array}$ \\
\hline
\end{tabular}

- power plant consivillage of fREeforti\%

POHER PLANT FUEL CONSUMPTION-1976

$04 / 10 / 79$

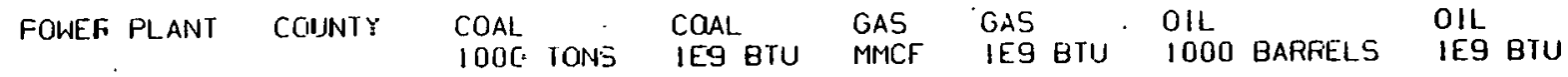

- SUNRISE HWY

- Euffello ave 
"SOL IDWASTE* $*$

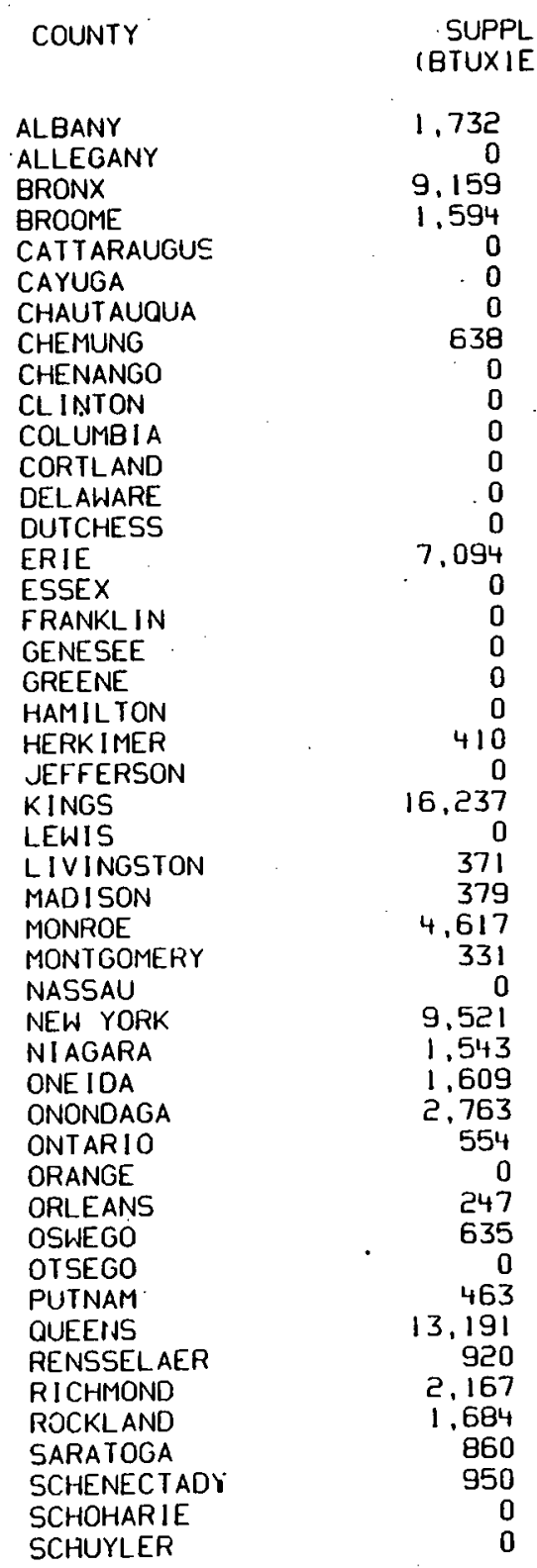




$\begin{array}{lr}\text { SENECA } & 0 \\ \text { STEUBEN } & 0 \\ \text { ST. LAWRENCE } & 0 \\ \text { SUFFOLK } & 8,380 \\ \text { SULLIVAN } & 0 \\ \text { TIOGA } & 348 \\ \text { TOMFK INS } & 0 \\ \text { ULSTER } & 0 \\ \text { WARFEN } & 0 \\ \text { WASHINGTON } & 0 \\ \text { WAYNE } & 534 \\ \text { WESTCHESTER } & 5,305 \\ \text { WYOMING } & 0 \\ \text { YATES TOTAL } & 54.836 \\ & \end{array}$

$\infty$
1
$\infty$
$N$

* ut IL ITy (İAS, BROCIKL y.y UNION) 8

$\begin{array}{ll}\text { RES COS } & \$ 3.720 / M F C \\ \text { CI COST } & \$ 3.190 / M F C\end{array}$

$\begin{array}{ll}\text { CI COST } & \$ 3.190 / \mathrm{MFC} \\ \text { PA COST } & \$ 2.730 / \mathrm{MFC}\end{array}$

\begin{tabular}{lrr} 
COUNTY & RES DEM & CI DEM \\
MCF & \\
MCF \\
KINGS & $44.927,376$ & $10,520.457$ \\
QUEENS & 22.391 .367 & $4.859,982$ \\
RICHMOND & 5.647 .846 & 939,938 \\
\multicolumn{1}{c}{ TOTALS } & $72,969,589$ & 16.320 .377
\end{tabular}

PA DEM
MOF

2. 168,892

l. 081.099

272.653

$3.522,6.14$
TOTAL

57.616 .725

$28,335,1448$

$6,860.437$

92.812 .610 
"UTIL ITY(GAS, CENTRAL HUDSON)\%

RES COST $\$ 3.250 / M F C$

CI COST \$2.030/MFC

\begin{tabular}{|c|c|c|}
\hline COUNTY & $\begin{array}{l}\text { RES DEM } \\
\text { MCF }\end{array}$ & $\underset{M C F}{C I}$ \\
\hline $\begin{array}{l}\text { ALBANY } \\
\text { OUTCHESS } \\
\text { GREENE } \\
\text { ORANGE } \\
\text { ULSTER }\end{array}$ & $\begin{array}{r}55,824 \\
1.706,595 \\
100.129 \\
1.232 .583 \\
541.506\end{array}$ & $\begin{array}{r}89,453 \\
2,121,313 \\
146,396 \\
149,795 \\
312,885\end{array}$ \\
\hline
\end{tabular}

PA DEM

TOTAL

13,165

294,208

39.634

151.133
57.340

58,442

.125 .116

286.159

1.533 .511

555,480

7.014 .959

*UTILITY(GAS, COLUMBIA):

COUNTY
ALLEGANY
BROOME
CATTARAUGUS
CHEMUNO
DELAWARE
ORANGE
SCHUYLER
STEUBEN
SULLIVAN
TIOGA
YATES

TOTALS

$$
\begin{gathered}
\text { RES DEM } \\
\text { MCF } \\
10.983 \\
7.492 .856 \\
1.065 . .110 \\
32, .361 \\
378.308 \\
0 \\
297.983 \\
36.644 \\
185.124 \\
90.558 \\
9.589 .927
\end{gathered}
$$

\section{DEM}

$3.679,228$

$5,409,795$

$$
1.984
$$

309,052

7.955

257,388

987,585

4.747

71,440

10.746 .643
PA DEM

TOTAL

MCF

12,098

$11,172,081$

6.471 .905

34.345

687.360

7,955
555,371

1.024 .229

4.747

201.478

336.570 
- JTILityigas, CON EDi\%

\section{GAS}

\section{RES COST \$4.260/MFC \\ Cl COST \$2.900/MFC}

COUNTY

RES DEM MCF

CI DEM
MCF

$\begin{array}{lr}\text { ERONX } & 9,088,000 \\ \text { NEW YORK } & 7.151,000 \\ \text { QUEENS } & 8.392,000 \\ \text { WESTCHESTER } & 15.583 .000 \\ & \\ \text { TOTALS } & 40,214.000\end{array}$

$5.928,000$ $12,183,000$

$5.052,000$

$30,396.000$

$\infty$
1
$\infty$
$\infty$
CON ED

1976

A CIEM
MCF

TOTAL
MCF

$1.367,0.00$

$1.023,000$

546,000

4.416 .000

4.416 .000

1976
$16,383,000$ $20,357,000$ $13,990,000$ $24,296,000$

$75.026,000$
"UTIL ITYIGAŚ, CJRNINJI:

\section{GAS SUPPLY FROM UTILITY}

RES COST \$1.538/MFC

CI COST \$1.304/MFC

PA COST \$1.447/MFC

COUNTY

CHEMUNG
STEUBEN

TOTALS
RES OEM MCF

134,438

1.961 .828

2. 096,266
CI DEM

12,094
3.374 .845
3.386 .939

CORNING

,

PA JEM

4.349

229,845

234,694
TOTAL
MCF

151.381 $5,566,518$

5.717 .899 
*UT IL ITY(GAS, LILCO)

GAS SUPPLY FROM UTILITY LILCO

1976

$\begin{array}{ll}\text { RES COST } & \$ 3.360 / M F C \\ \text { CI COST } & \$ 2.730 / M F C\end{array}$

\begin{tabular}{lcr} 
COUNTY & RES DEM & CI DEM \\
MCF & MCF \\
NASSAU & 14.310 .373 & $8,725.439$ \\
OUEENS & $1,070.563$ & 659.320 \\
SUFFOLK & 12.365 .625 & $6,001.971$ \\
\multicolumn{1}{c}{ TOTALS } & 27.746 .561 & $15,386.730$
\end{tabular}

PA DEM

TOTAL

MCF

$23,035.812$

1.729 .883

18.367 .596

$43,133,291$

ro
1
$\infty$
un

"Utilityigas, national FUeli\%

\section{RES COST \$2.208/MFC}

CI COST \$1.857/MFC

COUNTY
ALLEGANY
CATTARAUGUS
CHAUTAUQUA
ERIE
GENESEE
MONROE
NIAGARA
STEUBEN
WYOMING

RES. DEM

MCF

CI OEM

PA DEM

IOTAL

$1,448,183$

$2,420,613$

MCF

MCF

MCF

2. 729.614

$3.934,038$

8.253,084

99.978 .863

$59,634,424$

.513 .425
69.486

$40.344,439$

$2.174,198$

1.756 .434

369,451
7.777 .8968

4.201,148

7.777 .896

1.275 .614

817.673

TOTALS

$80,887.216$

$54,596,213$

849.135

$11,979,344$

$1.979,344$

1.887 .127

.5 .483 .429 
"UTILITYY(GAS, NI AGARA MOHL.HK.)X

\section{GAS JUPPLY FROM UTILITY NIAGARA MOHAWK}

1976

$\begin{array}{ll}\text { RES COST } & 5.330 / M F C \\ \text { CI COST } & 51.900 / M F C\end{array}$

COUNTY

ALBANY

CCLUMBIA

FLLLTON

HERK IMER

MA.DISON

MONTGOMERY

OME IDA

OMONOAGA

OSWEGO

RENSSELAER

SARATOGA

SCHENECTADY

WARREN

WASHINGTON

TOTALS
RES DEM
MCF

. 5,715

660,515

$, 484,232$

1. टब1. 398

2. 132.801

1.155 .141

1.E29.922

16.919 .351

2. 917.868

3.3100.064

3.519 .510

4.936.104

853,883
650,515

37.156 .236
CI DEM

$4,525,618$

654,355

654,355
$1.068,421$

126.449

$1.620,987$

1.092 .425
1.070 .320

$1,070,320$

$12,019,193$

2. 030.503

$1,878,367$

2. 225,856

5. 222,605

941,811
654,355

$38,095,216$
PA DEM
MCF

TOTAL
MCF

12. 138.333

1.314 .870
2.552 .653

$1.407,847$

3.753 .788

2.217 .566

2.700.242

$14,016,168$

$28,938,544$

$4.948,371$

5.178 .431

5.745.366

7.208.709

$1.795,694$

1.314 .870

95.261 .452 
RES COST \$2.079/MFC

$\begin{array}{ll}C l \text { COST } & \$ 1.674 / M F C \\ \text { PA COST } & \$ 1.653 / M F C\end{array}$

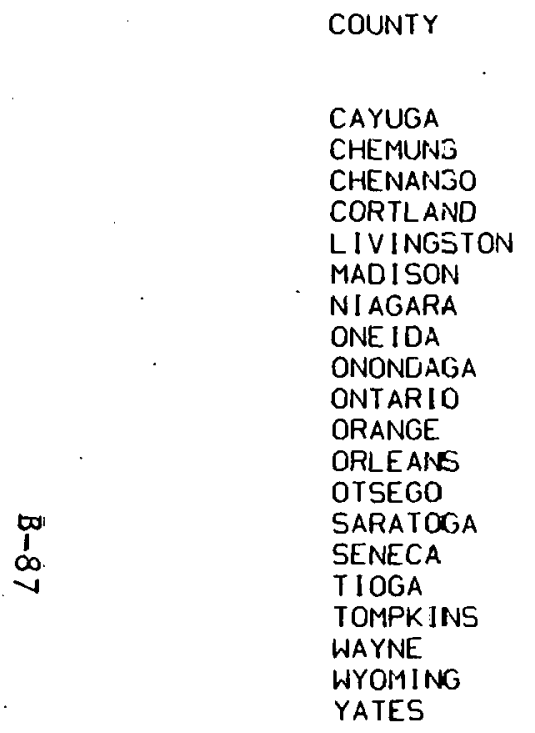

TOTALS

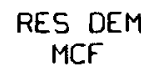

$2,127,648$

$4.447,455$
379,897

1.426 .110

473.131

88.730

1.668 .611

50.526

301.901

$1,988,528$

208.211

759,492

483,233

157,168

886,926

321.216

1.989 .016

$, 282,030$

17.950
364.371

19.422 .150
CI DEM

$1,432,911$
$5,275,200$

359,369

.384 .059

17,566

$2.309,032$

58.027

67.884
.571 .860

$.571,860$
135,351

445. 026

278.279

865,484

269.716

2. 080.724

1.025 .692

5,402
217,637

$18,228,271$
NYSE+G

PA DEM

MCF

286.826

615,445

33.842

370.549

45.159

183.620

230,916

295

29.862
347.111

347.111

20.626

83.192

25,362

77.300

59,382

1.053 .929

210.837

1.091

36.840

3.720 .189
TOTAL

3.847 .385 10.338 .100 773,108

3.180 .718 289.916

$4,208,559$

108,848 399.647

3.907 .499 364,188 1.287 .710 786,874 208,097 .829 .718 650.314 $5,123,669$ 2.518 .559 24.443 618.848

$41,370,610$

"UTILITYIGAS, ORANGE+ROCKLAFIOI\%

RES COST \$2.390/MFC

\begin{tabular}{lcc} 
COUNTY & \multicolumn{1}{c}{ RES DEM } & CI DEM \\
MCF & MCF \\
ORANGE & 3.130 .572 & 1.826 .908 \\
ROCKL_AND & 10.668 .647 & $7,282.014$ \\
\multicolumn{1}{c}{ TOTALS } & 13.799 .219 & 9.108 .922
\end{tabular}

PA DEM
MCF

0
0

TOTALS

13.799 .219

$9,108,922$

\section{TOTAL}

$4,957,480$ 17.950 .661

22. 908,141 
-UTILITYIGAS,FAV:LLIOVIX

GAS SUFPLY FROM UTILITY PAVILLION

$\begin{array}{ll}\text { RES COST } & \$ 1.910 / \mathrm{MFC} \\ \mathrm{CI} \operatorname{COST} & \Phi] .603 / \mathrm{MFC}\end{array}$

\begin{tabular}{lcc} 
COINTY & $\begin{array}{c}\text { RES DEM } \\
\text { MCF }\end{array}$ & CI DEM \\
MCF & \\
GENESEE & 383,464 & 635,977 \\
LIVINGSTON & 871.204 & 304.682 \\
WYOMING & $4 E 7,192$ & 382,577 \\
\multicolumn{1}{c}{ TOTALS } & $1,6 \Xi 1,860$ & $1,323,436$
\end{tabular}

PA DEM
MCF

TOTAL

0

0

1.019 .441

I. 176,086

$3,005,296$

$\infty$
1
$\infty$
$\infty$

"UTIL ITY(GAS.PEMN+SOUTH):

GAS SUPFEY FROM UTILITY PENN-SOUTH

1976

RES COST $22.226 / M F C$

Cl COSB \$1. 991/MFC

$\begin{array}{lcc}\text { COUNTY } & \text { PES DEM } & \text { CI DEM } \\ \text { MCF } & \text { MEF } \\ \text { TIOGA } & 115.056 & 102.395 \\ \text { TOTALS } & 115,056 & 102.395\end{array}$

PA DEM
MCF

TOTAL
MCF

0

217.451

TOTALS

115.056

102,395

217.451 
*UTILITY(GAS, RG+E)\%

GAS SUPPLY FROM UTILITY RG+E

RES COST \$2.450/MFC

CI COST \$1.890/MFC

COUNTY

GENESEE

LIVINGSTON

MONROE

ONTARIO

ORLEANS

WAYNE

TOTALS

RES OEM

MCF

CI DEM

MCF
224,169
84.303
$27,193.040$
189.682
47.899
852.610

$28,591.703$
80,845
30.403
250,531
68,407
17.275
307.487

$15,754,948$
1976

PA DEM

TOTAL

MCF

30,181

11.350
670,568

$.670,568$
25,538

6,449

114,791

$, 858,877$
335.195

$44,114,139$

283,627

71.623

$46,205,528$

-UT IL ITY (GAS, ST . LAWRENCE )

RES COST \$2.840/MFC

CI COST \$2.180/MFC

$\begin{array}{lcc}\text { COUNTY } & \text { RES DEM } & \text { CI DEM } \\ \text { MCF } & \\ \text { ST. LAWFENCE } & 1.544 .198 & 3.971 .183 \\ \text { TOTALS } & 1.544 .198 & 3.971 .183\end{array}$

PA DEM
MCF

0

0
TOTAL
MCF

5.515 .381

5.515 .381
TOTALS 
- UTILITYIGAS. SYRACUSE SUBURB.ANI:

GAS

$\begin{array}{ll}\text { RES COST } & \$ 1.978 / M F C \\ \text { CI COST } & \$ 1.645 / M F C\end{array}$

$\begin{array}{ccc}\text { COUNTY } & \text { RES DEM } & C I \text { DEM } \\ \text { MCF. } & \text { MCF } \\ \text { ONONDAGA } & 515.472 & 2,919,796 \\ \text { TOTALS } & 515,472 & 2,919,796\end{array}$

- UTIlitir poll ICENTRal huDSONj\%

POWER PLANT

COXSACKIE

DANSKAMMER

NEVERSINK

ROSETON

SO. CAIRO

STURGEON

TOTAL

\begin{tabular}{l} 
POLLUTION INM \\
COUMTY \\
\hline GREENE \\
ORAMISE \\
ULSTER \\
SULLIVAN \\
ORAISE \\
GREENE \\
ULSTER
\end{tabular}

Toral

"UTILITY POLL

S.A. CARLSON

TOTAL
POLLUTION IN COUYTY$$
\text { . }
$$

TONS FOR ALDEHYDES ALDEHDES

77.8

34.2

IIE. 0

$\begin{array}{rc}\text { PA DEM } & \begin{array}{c}\text { TOTAL } \\ \text { MCF }\end{array} \\ 0 & 3.435 .268 \\ 0 & 3.435 .268\end{array}$

ISENTE
CARBON MUDSON MONO HYDRO CARBCN NITROGEN OXIDE

CARBON MONO HYORO CARBCN

3.2

155.5

$800^{4} \cdot 0$

68.5

3525.8

224.0

11529.8

4.6

8.8

PARTICULATES SULFUR DIOXIDE

622.0

10867.6

274.0

5999.5

896.0

16867.1
CITY OF JAMESTOWN 1976

CITY OF JAMESTOWN 1976
CARBON MONO HYDRO CARBON . NI TROGEN OXIDE
PARTICULATES SULFUR DIOXIDE
TONS FGF
ALDEHYDES ALDEHYOES 


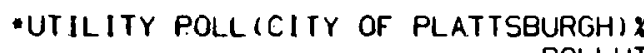

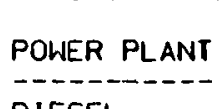

COUNTY

POLLUTION IN

DIESEL

TOTAL

- UTILITY POLLICON ED) $x$

\section{POW:-R PLANT}

ARTHUR KILL

ASTORIA

BOWL INE

GOWANUS

HUDSON AVENUE

INDI AN POINT

KENT AVE

NARROWS BAY

RAVENSWOOD

ROSETON

WATERSIDE

$595 T$
74 ST

TOTAL

POLLUTION IN
COUNTY
RICHMOND
OUEENS
ROCKLAND
NEW YORK
KINGS
KINGS
WESTCHEST
KINGS
KINGS
QUEENS
GRANGE
NEW YORK
NEW YORK
NEW YORK

TONS FOR

ALDEHYDES

ADD - - - -

CITY OF PLATTSBURGH 1976

CARBON MONO HYORO CARBON NITROGEN OXIDE -

PARTICULATES SULFUR DIOXIDE PARTICULATES SULFUR DIOXIDE

\begin{tabular}{r} 
TONS FOR \\
ALOEHYDES \\
\hline 115.1 \\
211.8 \\
70.6 \\
47.8 \\
19.9 \\
20.5 \\
2.5 \\
.0 \\
16.5 \\
267.7 \\
68.5 \\
44.6 \\
115.8 \\
13.3
\end{tabular}

1014.6
CON ED

CARBON MONO HYORO CARBON -....-......-

12081.5

25241.8

7409.6

5016.4

2088.1

2147.7

260.2

72.4

1728.7

28107.1

7051.3

4687.8

11920.1

1370.6

231.6

26.6

106115.0

2460.9

2029. 2
PARTICULATES SULFUR DIOXIOE

$\begin{array}{rr}920.5 & 4756.5 \\ 1694.6 & 8420.1 \\ 564.6 & 3590.5 \\ 382.2 & 2051.0 \\ 159.1 & 442.7 \\ 163.6 & 878.1 \\ 19.8 & 102.4 \\ .3 & .5 \\ 131.7 & 288.0 \\ 2141.5 & 11066.2 \\ 548.0 & 11999.0 \\ 357.2 & 1916.7 \\ 926.4 & 2732.5 \\ 106.5 & 326.3\end{array}$

8116.0

48570.5 
- Ut Il ity poll (LILCO)

POWER PLANT

BARRETT

E. HAMPTON

FAR ROCKAWAY

GLENWOOD

HOLBROOK

MONTAUK

NORTHPORT

PORT JEFFERSON

SHOREHAM

SOUTHOLD

S. HAMPTON

W. BABYLON

TOTAL

\begin{tabular}{l} 
POLI.UTION』 IN \\
COUNTY \\
\hline NASSAU \\
SUFFOLK \\
NASSAU \\
NASSAU \\
SLEFOLK \\
SLFFOLK \\
SLIFFOLK \\
SUFFOLK \\
SLIFFOLK \\
SUFFOLK \\
SUFFGLK \\
SUFFOI.K
\end{tabular}

SUFFOI.K

- UTIL itr polliniagara MOH.suKiz

\begin{tabular}{ll} 
POWER PLANT & POLLUTION \\
\hline ALBANY & A_BANY \\
COLTON & \\
DIESEL & \\
DUNKIRK & \\
HUNTLEY & CHAUTAUQUA \\
LEASEO & ERIE \\
OSWEGO & \\
OWNED & OSWEGO
\end{tabular}

OSWEGO

OWNED

ROSETON

ROTTERDAM

SCHOOL ST

SHERMAN IS.

SPIER FALLS
STEWARDS BRIDGE

TRENTON

$$
\text { TOTAL. }
$$

\begin{tabular}{c} 
TONS FOR \\
ALDEHYLIES \\
\hline 61.5 \\
11.4 \\
40.8 \\
12.5 \\
213.8 \\
94.6 \\
.0
\end{tabular}

434.7
LILCO

1976

$184.5 \quad 123.0$

34.3

122.5
37.5

641.5

283.7
.1

.1

1304.4
NI TROGEN OXIDE 6458.4

1199.5

4236.5

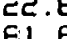

E1. 6

427.7

189.1
.0

.2

869.4
1312.0

22453.5

9929.1
2.2

8.8

45650.0
PARTICULATES SULFUR DIOXIDE

492.1 3325.2

$91.4 \quad 508.6$

$326.6 \quad 2142.0$

$\begin{array}{lr}326.6 & 2142.0\end{array}$

$1710.7 \quad 82622.5$

$\begin{array}{rr}756.5 & 34431.3 \\ .2 & .7\end{array}$$$
.7
$$

3478.2

123430.0

247.1

1931.2

904.5

50520.5

3773.1

191281.3

\section{PARTICULATES SULFUR DIOXIDE} 589.2 26698.5

797.1 $\begin{array}{rr}531.6 & 53182.9 \\ 054.6 & 59344.6\end{array}$

$774.0 \quad 39955.2$

$548.0 \quad 11999.0$

$\begin{array}{rr}10.2 & 61.1\end{array}$
CRANGE

SCHENECTA.

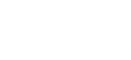


*UTIL ITY POLL (NYSE+G) $\%$

FOWER PLANT

COUDEY

GREENIDGE

HICKLING

HOMER CITY

JENNISON

MILLIKEN
MISC. DIESEL

MISC. HYDRO

TOTAL

+UT IL I TY POLL (ORANGE +RJCKLAND ) $x$

POWER PLANT

BOWL INE

HILLBURA

HYDRO

LOVETT

SHOEMAKER

TOTAL

\section{"UTILITY POLl (PASNYI: \\ POWER PLANT \\ AUX. PUIAPED STORAGE \\ BLENHIEN GILBOA \\ FITZPATRICK \\ INDIAN POIN \\ MOSES NIAG. LEWISTON \\ MOSES POWER DAM}

TOTAL

ROCKLAND

ORANGE

\begin{tabular}{l} 
POLLUTION IN \\
COUNTY \\
\hline BRODME \\
YATES \\
STEJIEEN \\
CHENANGO \\
TOMPKINS
\end{tabular}

\begin{tabular}{c} 
TONS FOR \\
ALDEHYDES \\
\hline 1.9 \\
1.0 \\
.5 \\
1.9 \\
5.3
\end{tabular}

NYSE + G

1976

\begin{tabular}{rrr} 
CARBON MONO & HYDRO CARBON & NITROGEN OXIDE \\
\hline 175.0 & 52.5 & 3150.0 \\
193.0 & 57.9 & 3474.0 \\
204.5 & 61.4 & 3681.0 \\
97.0 & 29.1 & 1746.0 \\
376.0 & 112.8 & 6768.0
\end{tabular}

5.3

1045.5

313.7

18819.0

1369.7

61373.9

PARTICULATES SULFUR DIOXIDE $\begin{array}{ll}229.3 & 9243.5\end{array}$ 252.8 9974.2 $267.9 \quad 8470.4$

127.1

492.6

4681.5

29004.6

\begin{tabular}{|c|c|c|c|c|}
\hline TONS & ORANGE+ROCKL & & 1976 & \\
\hline ALDEHYDES & CARBON MONO & HYDRO & CARBON & NITROGEN OXIDE \\
\hline 17.7 & 53.0 & & 35.4 & 1857.0 \\
\hline .0 & .1 & & .1 & 1.14 \\
\hline 50.8 & 152.3 & & 101.5 & 5329.5 \\
\hline .0 & .1 & & .1 & .4 \\
\hline 68.5 & 205.5 & & 137.1 & 7195.3 \\
\hline
\end{tabular}

PARTICULATES SULFUR DIOXIDE

$\begin{array}{rr}141.5 & 899.8 \\ .3 & .7\end{array}$

ROCKLAND

ROCKLAND

68.5

POLLUTION IN TONS FOR
COUNTY
ALDEHYOES

PASNY

1976

CARBON MONO HYDRO CARBON NITROGEN OXIDE
PARTICULATES SULFUR DIOXIOE 
-UTILITY POLL (RG+E)

POWER PLANT

POWER PLANT

ROCH 3

$\mathrm{ROCH}$

TOTAL

\section{COUPTY}

POLL

COUh TY

MONFOE

MONF:OE

$\begin{array}{r}\text { ALOEHYDES } \\ \hdashline \text { TONS FOR } \\ \text { ALDEHYDES } \\ \hline \begin{array}{r}20.0 \\ 1.2\end{array}\end{array}$

$2: . \overline{3}$

\begin{abstract}
OF FFEEPORT I:
POLLUT
\end{abstract}
"UTIlity POLl
POWER Plant

GUFFALO AVE

SUNRISE HWY

TOTAL. COUNTY

\begin{tabular}{rrr} 
CARBON MONO & HYORO CARBON & NITROGEN OXIDE \\
\hline RG+E & \multicolumn{1}{c}{1976} \\
CAFBON MONO & HYORO CARBON & NITROGEN OXIDE \\
\hline $\begin{array}{r}157.1 \\
257.6\end{array}$ & 68.6 & 3823.7 \\
414.7 & 77.3 & 4637.2 \\
& 145.9 & 8460.9
\end{tabular}

PARTICULATES SULFUR DIOXIDE

PARTICULATES SULFUR DIOXIDE

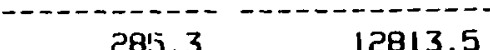

$337.5 \quad 18787.3$

$622.8 \quad 31600.8$
POLLUTION IN TONS FOR VILLAGE OF FREEPORT 1976

ALCEHYDES CARBON MONO HYDRO CARBON NITROGEN OOIDE

PARTICULATES SULFUR DIOXIDE 
"UTIL POLL PER CIY*\%

COUNTY

\section{ALBANY}

BROOME

CHIAUTAUUUA

CHENANGO

ERIE

GREENE

KINGS

MONROE

NASSAU

NEW YORK

ORANGE

OSWEGO

QUEENS

RICHMOND

ROCKL AND

SCHENECTA

STEUBEN

SUFFOLK

SULL IVAN

TOMPKINS

ULSTER

WESTCHEST *

YATES

TOTAL

"UTIL POLL PER UTIL * *

\section{UTILITY}

CENTRAL HUDSON

CITY OF JAMESTOWN

CITY OF PLATTSBURGH

CON ED

LILCO

NIAGARA MOHAWK

NYSE +G

ORANGE +ROCKLAND

PASNY

VILLAGE OF FREEPORT

TOTAL
PCLLUTION IN TONS FOR NEW YORK STATE BY COUNTY 1976

ALOEHYDES CARBON MONO HYDRO CARBON NITROGEN OXIDE

$\begin{array}{rr}73.6 & 220.9 \\ .9 & 175.9 \\ 3.0 & 608.5 \\ .5 & 97.0 \\ 4.0 & 805.0 \\ 56.9 & 170.6 \\ 21.3 & 414.7 \\ 113.7 & 341.3 \\ 221.5 & 282.4 \\ 249.0 & 12.2 \\ 96.7 & 290.2 \\ 479.5 & 1438.6 \\ 115.1 & 345.5 \\ 139.1 & 417.1 \\ 1.3 & 3.8 \\ 1.0 & 204.5 \\ 321.0 & 963.1 \\ 1.9 & \\ 2.0 & 376.0 \\ 1.0 & 77.4 \\ 1903.5 & 193.0\end{array}$

1903.5

7366.8
PARTICULATES SULFUR DIOXIDE

$\begin{array}{rr}147.3 & 7732.9 \\ 52.5 & 3150.0 \\ 182.6 & 10953.0 \\ 29.1 & 1746.0 \\ 241.5 & 14490.0 \\ 113.7 & 5968.9 \\ 145.9 & 8460.9 \\ 227.4 & 11944.4 \\ 443.1 & 22994.9 \\ 498.1 & 25637.1 \\ 193.5 & 10158.4 \\ 959.1 & 50348.9 \\ 230.1 & 12081.2 \\ 278.2 & 14600.5 \\ 2.6 & 134.6 \\ 61.4 & 3681.0 \\ 642.0 & 33705.6 \\ 112.8 & 6768.0 \\ 5.0 & 260.2 \\ 57.9 & 3474.0 \\ 4623.8 & 248290.5\end{array}$

$\begin{array}{rr}589.2 & 26698.5 \\ 229.3 & 9243.5 \\ 797.1 & 53182.9 \\ 127.1 & 4681.2 \\ 1054.6 & 59344.6 \\ 454.7 & 1609.3 \\ 622.8 & 31600.8 \\ 910.1 & 5975.8 \\ 1772.3 & 7026.5 \\ 1992.3 & 40865.5 \\ 774.0 & 39995.2 \\ 3836.1 & 19486.3 \\ 920.5 & 4756.5 \\ 1112.5 & 7073.5 \\ 10.2 & 61.1 \\ 267.9 & 8470.4 \\ 2568.1 & 117454.2 \\ 492.6 & 29004.6 \\ 19.8 & 102.4 \\ 252.8 & 9974.2 \\ 18804.0 & 476607.0\end{array}$

POLLUTION IN TONS FOR NEW YORK STATE BY UTILITY 1976

ALDEHYDES CARBON MONO HYDRO CARBON NITROGEN OXIOE

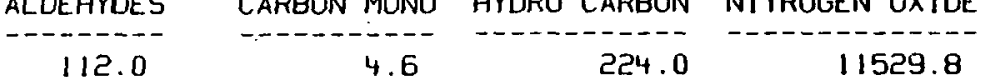

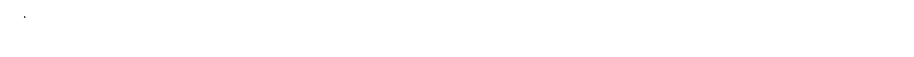

$\begin{array}{rrrr}1014.6 & 2460.9 & 2029.2 & 86115.0 \\ 434.7 & 1304.1 & 869.4 & 45650.0 \\ 2147.1 & 1931.2 & 9014.5 & 50520.5 \\ 5.3 & 1045.5 & 313.7 & 18819.0 \\ 68.5 & 205.5 & 137.1 & 7195.3 \\ 21.3 & 414.7 & 145.9 & 8460.9\end{array}$

1903.5

7366.8

4623.8

218030.5
PARTICULATES SULFUR DIOXIDE B96.0 16867.1

$3478.2 \quad 123430.0$

3773.1 - 191281.3

$1369.7 \quad 61373.9$

$548.2 \quad 31183.4$

$622.8 \quad 31600.8$

$18304.0 \quad 476607.0$ 
APPENDIX C

COMPUTER OPERATIONS

C-1 


\section{Appendix C}

\section{Introduction}

In thits appendir we address theictial use of the county lepel data base and the analyt1c models of the NYSEIAS. For each model and the data base we review its use in a numerical problem indicating user operations at the access terminal. It is necessary to state though, that the contents of this appendix are not thtended as a set of operating:tistructions anduthat user tratning: In the operation of the several systems is required.

\section{ESNS}

If the user has successfuily connected to intercom the system should respond with the following:

DEOCXLATEH IHTEFTEM 4.5

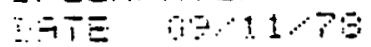

THE i.

OEESE LOEIH

Gín

BUTEF MSEF MHUEATEO

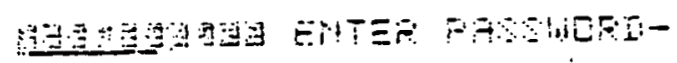

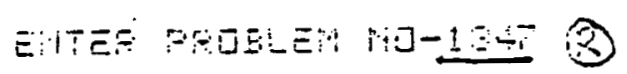

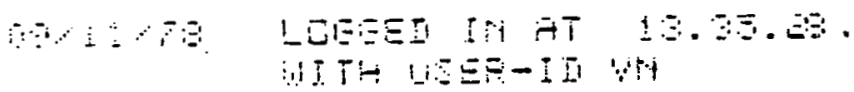

1

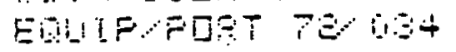

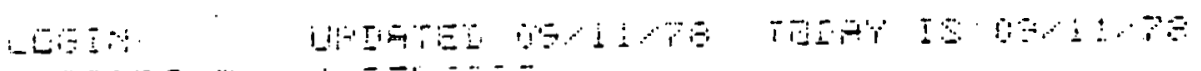

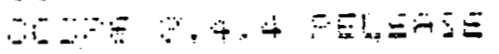

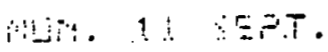

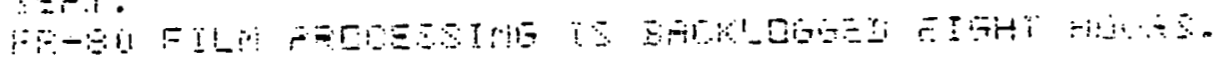

$7+1 .=2 \div$

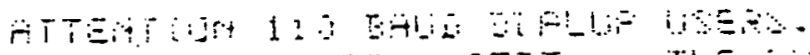

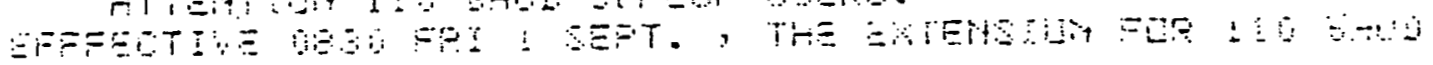

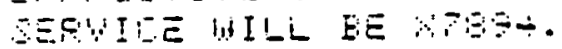

$\because 2$ MU⿴囗十⺝

F+1013:7 
The user is first requested to identify himself to the system. This is accomplished by typing LOGIN (R) where (R) is the symbol which denotes pressing the carrlage return key which involves the system program LOGIN. When requested enter your user name type: $\operatorname{KATZ}(R)$. When requested type your password: enter NEIL (R). (Note: the password is overprinted by the system for securtty reasons.) When asked type your problem number: 1347 (R) indicating the computer account number to which all charges are made. The system then responds with the date, time and message(s) of interest to users about the BNL system. At this point the user has gained access to Intercom and is requested to type further instruction:

:-1min-

In order to retrleve the PERTURB program from disk storage enter the following:

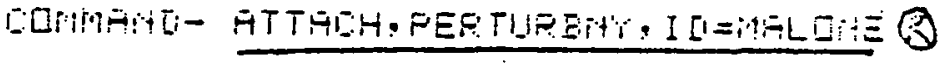

which should respond:

LFP. IS

FEFTIEE

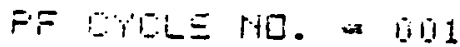

At this point the user is ready to call for the loading and execution of PERTURB whlch is accomplished by typing the single word PERTURB followed by a carriage return:

EUMAOA- FEFTHEE OP

The user is now running the PERTURB program and continues to be prompted for further information: 
THFE THE HAUE GF TLUA FILE:

(F)

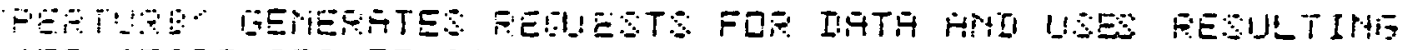

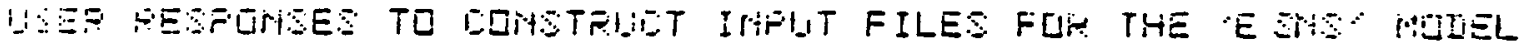

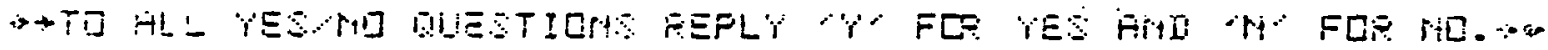

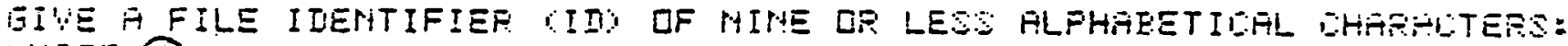
1YIO?

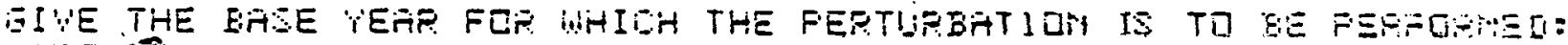
$198(3)$

THE THULLLIHE TITL FOF THE AHIHLYSIS

SHPLE DF FETTIFE USABE (R)

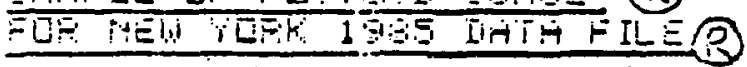

The first question asks for the name of the data flle to be perturbed, which In this case is NEW YORR. The user is then told to answer each question with elther "Y" or " " "for any YES/NO type questions. Should an entry be made which is not a " $\mathrm{Y}$ " or an " $\mathrm{N}$ " to a YES/NO type question, the question will be printed again and another opportunity given to respond correctly, Following this you must enter a file 1dentifler. This ID is used to store a copy of the file whIch PERTURB generates on user inputs. The user is then questioned as to which of the base years he wiskes to work with. (1985 is shown in the sample) After entering the base year, type in a two-line title (maximum of 70 characters per line) which you wish to assign.

After completing the above the user is querled as to whether or not he wishes to make additions (in the form of added processes) to the basic . New York RES.: Should this option be destred enter $Y$ :

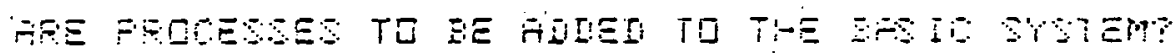
10

The user then must indicate the number of processes (Iiniks) to be added along with the number of new additional node necessary to accomodate the added processes:

*For processes included in the basic NYS RES see Figure 7. 
BTUE THE TOTHL HUMEER OF FFOEESES TO RE HIEI:

$1 \overbrace{0}$

GIYE THE TOTHL H!HESP OF HULES TO EE HIIEL:

$\stackrel{8}{B}$

In the above sample entrles have been made to request the addition of one new process and one new node. Perturb then requests the user to place the newly added link(s) within the existing network by asking for the node of orfigin and node of destination).

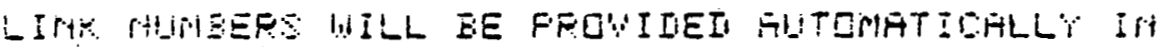

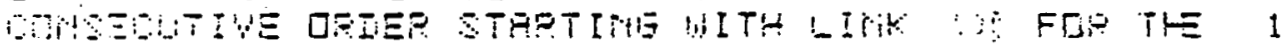

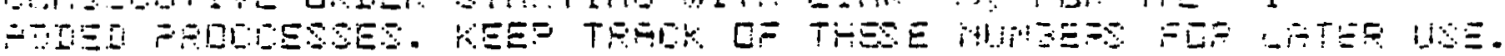

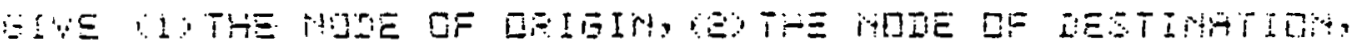

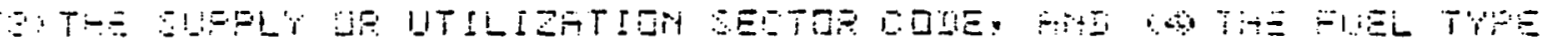

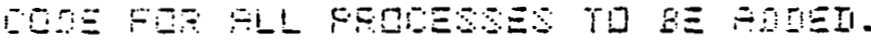

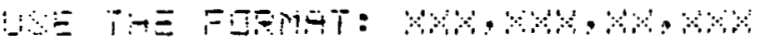

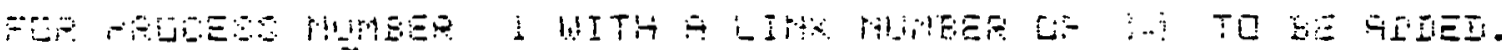

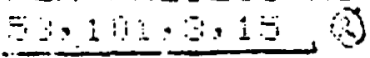

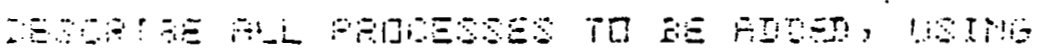

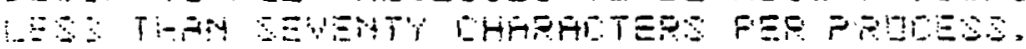

FCF FETESE HUMEER 1:

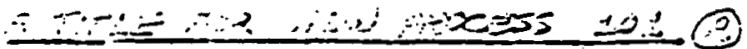

The above example adds a new process with node of origin 53, node of destination 101, sector code 3, fuel code 15. This process was given the arbitrary title "A title for new process 101 ".

After changes to the network itself have been made PERTURB allows the user to change the data associated whth each process. The first data items which the user can change (or add to) are the "data elements". ("parameters"; e.g. tons So $_{\mathbf{x}}$ emttted, occupational person-days, etc.) Note: At this point all parameters may be changed (or added to) except end uge demands (parameters 10, 42, 43), market allocations (parameter 1) and efficiencies (parameter 2). These will be asked for in subsequent questions. 
The above dialogue adds the efficiency for process number $10 I$ to the Input data (The effictency index is one of the following:

41 - for activity. level demands

42 - for direct fuel consumption

43 - for bastc energy demand)

After completing efflciency data inputs the program turns to and use demand data. The first question asks if anything at all is to be done with demand data. Note the following four questions carefully as they determine how the user wants the demands changed or added to:

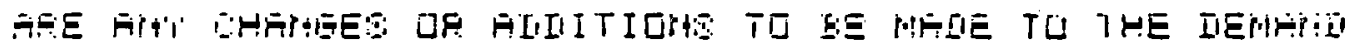
$\because$ YLLES:

$\because$

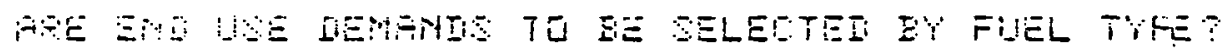

$\because 0$

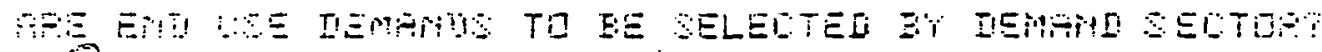

(3)

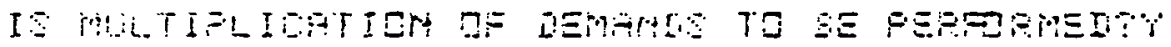

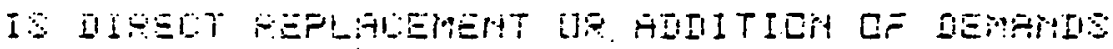

TQ IE HETFECHED?

依

The question "selectlon by fuel type". means the following:

The user has the option of selecting (by utilization fuel) only spectfic end use demands, with all other demands belng set to zero. As an example, if the user wanted to include only oil demands in the analysis $(s)$ he would answer this question "Y", and enter the code for oll later (see below). When the time came to do the actual calculations ESNSALL would collect all oil demands from the base year data file, apply any user changes, then reset all non-oil demands to zero, and finally perform the calculations. This option finds its greatest utility when it is desired to analyze the effects of only a (or several) specific demand fuel type(s) on the overall RES. The question about "selection by demand sector" is exactly analogous to the above. If the user wishes to maintain only a selected subset of end use demands based on their sector 
The dialogue to accomplish this goes as follows:

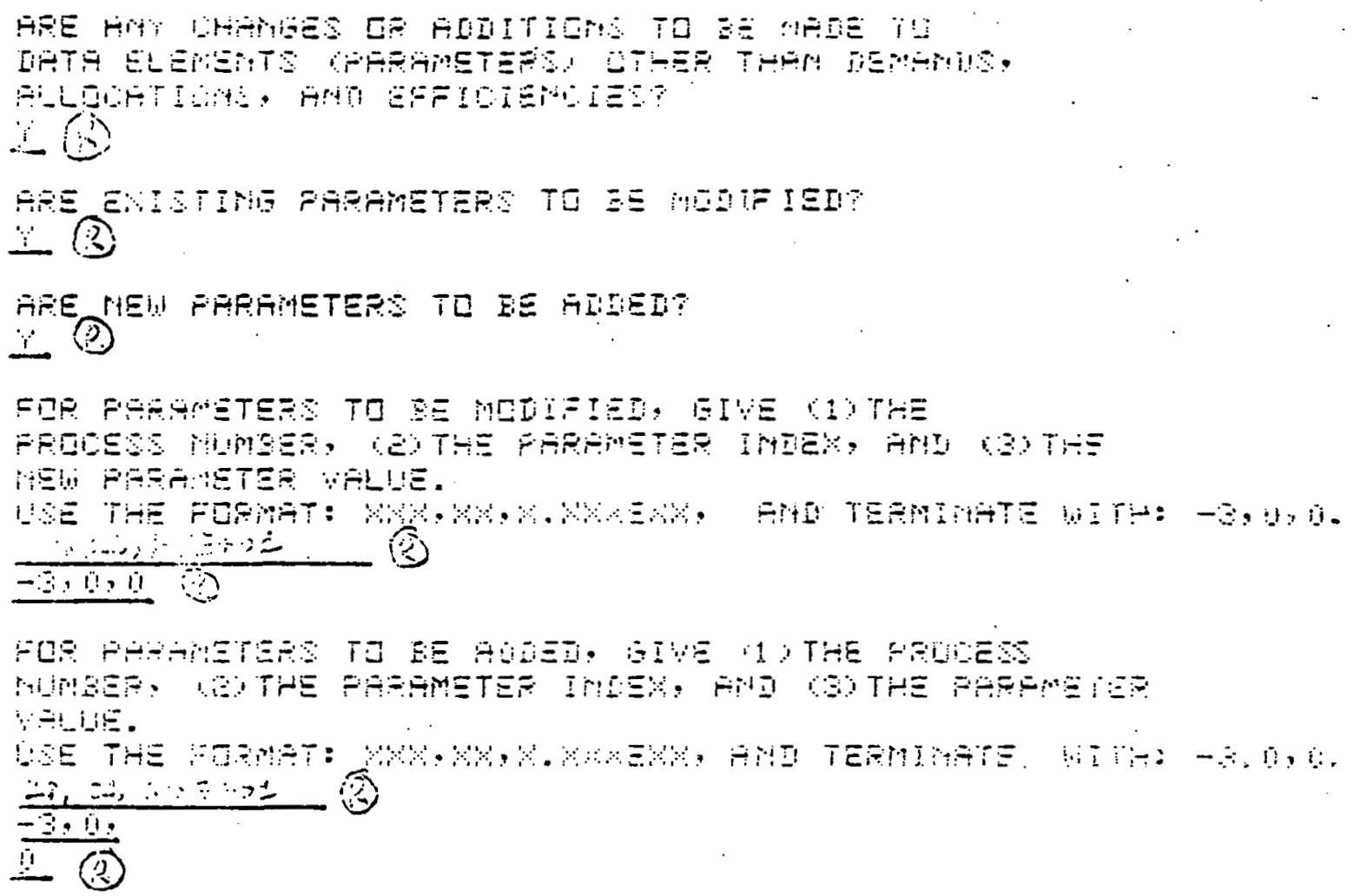

The above example changes existing parameter number 21 for process 26 to a new value of $1.8 \mathrm{E}+01$ and adds parameter number 21 for process 28 . After changing and/or adding to parameters PERTURB asks if it is desired to add (or modify) efficiency data: (Remember that if you added one or more new processes, an efficiency has to be entered for each of these new 1inks.)

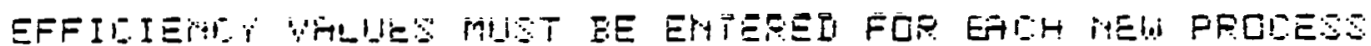

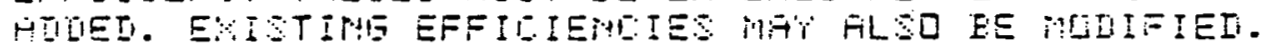

I HE THESOES HAVE ESEH HUDED.

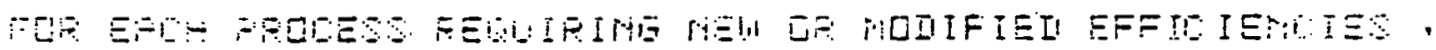

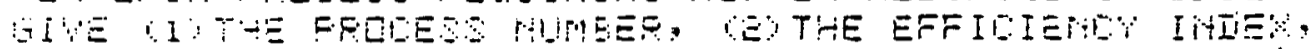

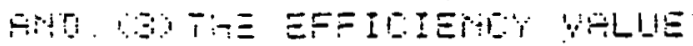

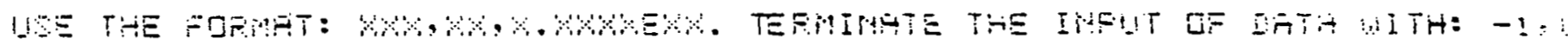

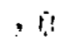

FEADIY:

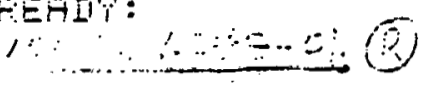

PEAIY:

$-1,0.20$ 
(resetting the demands for all non-chosen sectors to zero) then answer this question "Y" and enter the chosen sector code(s) later (see below).

The question relating to "moltiplication of demands" allows the analyst the capability of multiplying an end use demand by an arbitrary constant.

The final question asks about directly modifying or adilng to existing demand data. Answer this question " $T$ " if it is desired to modify a demand value (already in the base file) and/or add a new demand value.

Each question in the above section merely indlcated to the program how demand data was to be changed or added to. The next part of PERTURB asks what demand data is to be manipulated and requests entry of specific values for these changes/additions.

If the "Selection by fuel types" question was answered $Y$ this section Is called and the user enters the sector codes desired (as explained above):

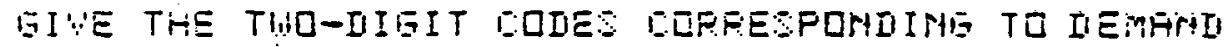

FIEL TYFES SELELTED FOF THIS FEPTTIREATIDR.

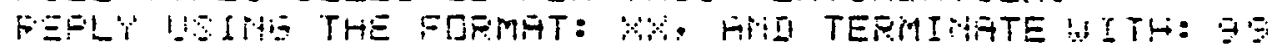

$\operatorname{BLE}=23$

DOUE= $=3$

EDE= औ

Simflarly, the chosen sector cnias are Innut:

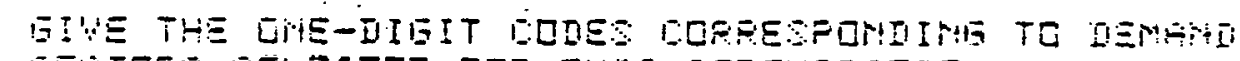

SEOTOSO SELELTED FUF THIS FEPTLEZATICH.

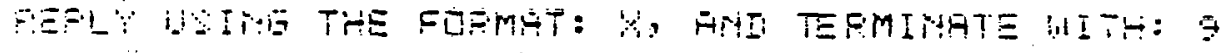

$$
\begin{aligned}
& \cos =3 \\
& \text { औUE }=2 \\
& \text { भIIE=2 (3) } \\
& \text {, } 105=2 \text { i }
\end{aligned}
$$


If arbitrary multiplication of demands is desired, the values for said multiplication are entered next (note this data is based on node number):

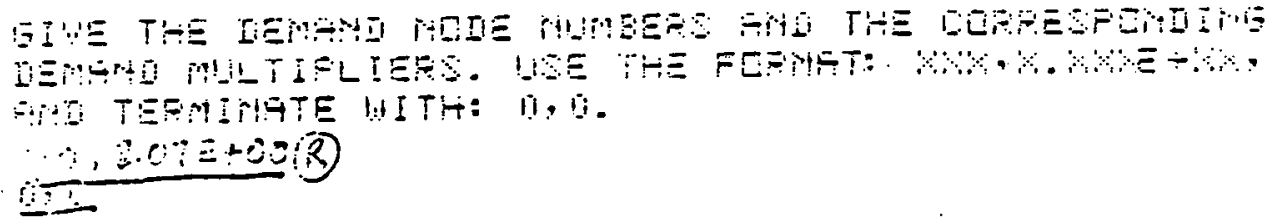

For modification or addition to demand yalues the next question is pertinent:

FEF MUDIFIEATION OF IHIIUIIUJAL DEMARISS, GIYE 19 THE

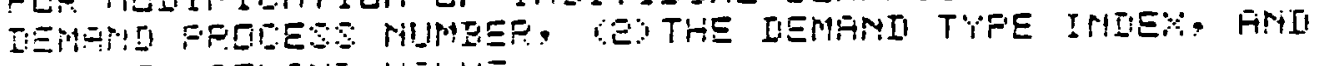
THE HEW SEHTHI ULLIE.

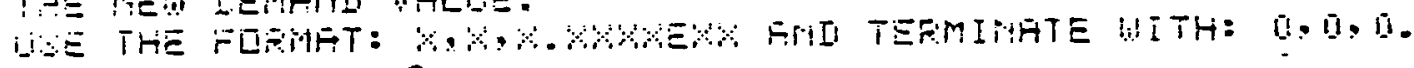

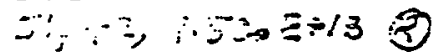

1.,

As seen above, the demand for process number 51 has been changed to $1.506 \times 10^{13}$ BTU. The demand type index referred to is one of the following: $\quad 10$ - Activity level demands

$$
\begin{aligned}
& 42 \text { - Direct fuel consumption } \\
& 43 \text { - Basic energy demand }
\end{aligned}
$$

After demand data inputs are completed, PERTURB asks the user about allocations:

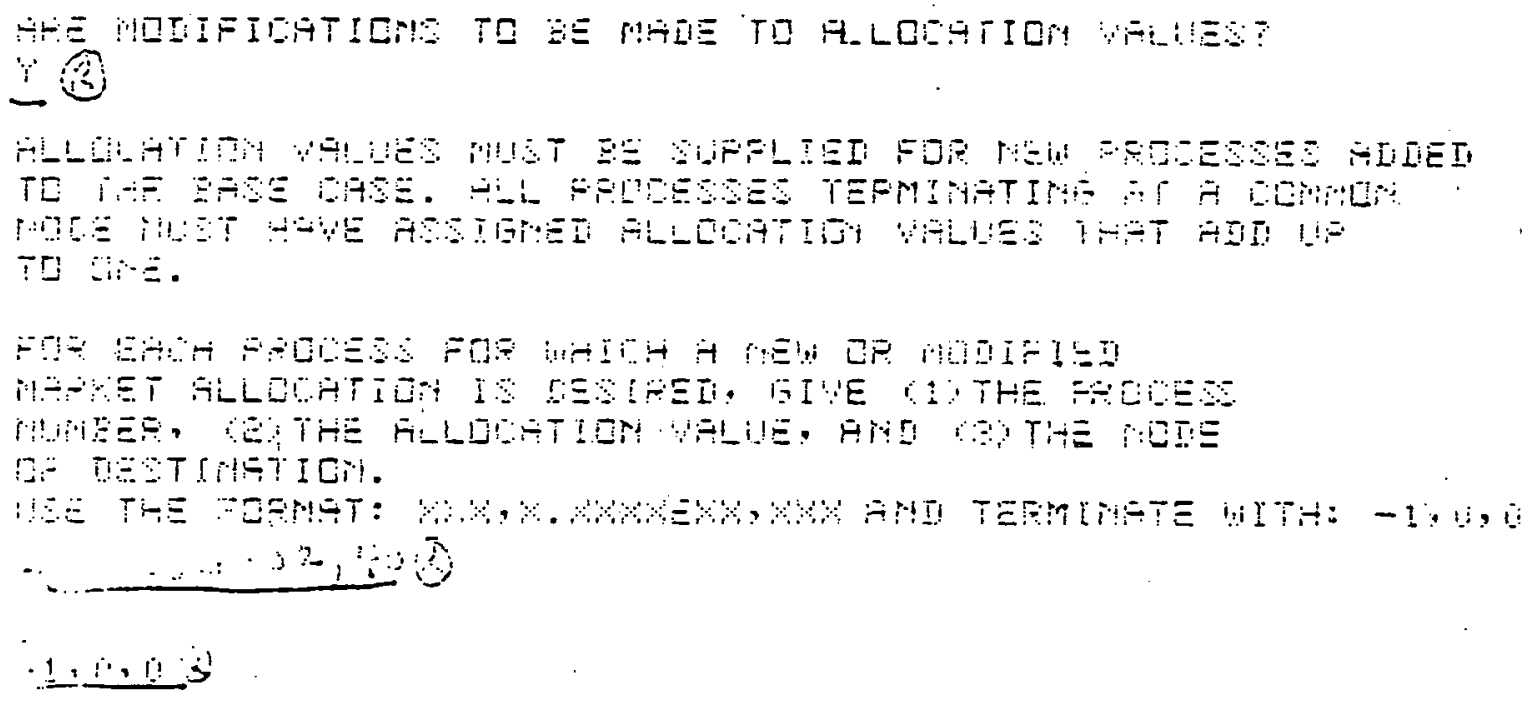


In this example the analyst has changed the allocation for process number 30 to $1.4 \times 10^{-2}$. New allocation values may also be added at this point. The next two questions query the user as to how output from ESNSAll is to be presented. The user has the obtion of requesting that output be

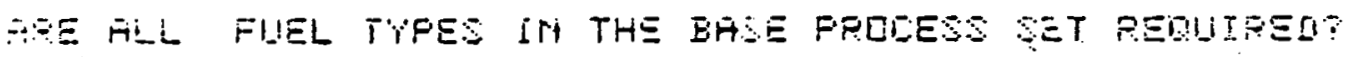
10

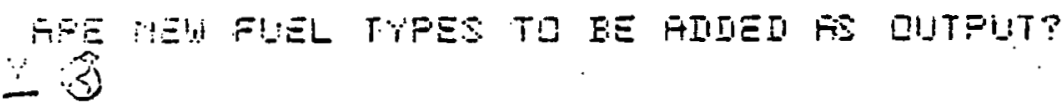

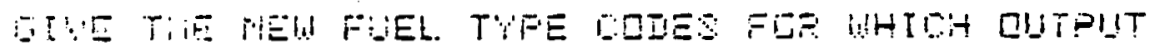

F TI, OE FIMTED.

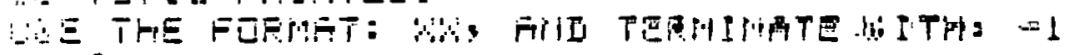

$\stackrel{-10}{=10}$

generated only for processes whtch utilize spectfic fuels. If a fuel is not selected for output, data associated with processes utilizing that fuel are still maintained, with all calculations involving that fuel carried out as normal. When output is generated, however, sections of the report dealing with those selected fuels will be supressed. (Note: this option should not be confused with one discussed earlier which allows end use demands to be zeroed by fuel.)

Should the user in the course of adding new processes define a new fuel type(s) he must declare it (then) by entering their code numbers in response to the second question of this section.

The next set of questions deal with whether or not data which the user has perturbed in a given year is to be propagated through subsequent pertubations.

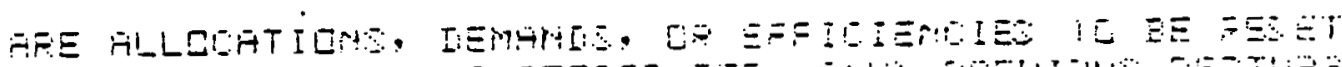

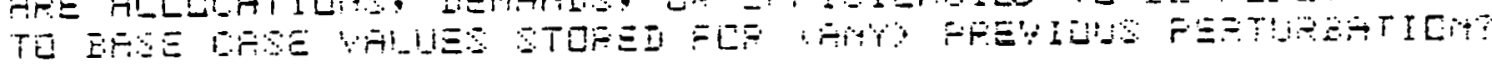
$\because 3$

HE ÄLLDETIDHS TU SE FESET?

$\because 8$

FEE IEMHTIS TO EE FESET

$\because 3$

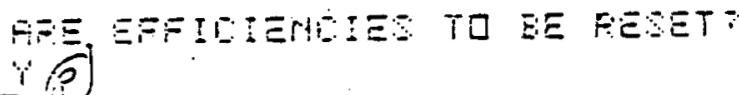


That is, should the changes the user makes in the first perturbation be carried over into subsequent ones or should the data be reset between perturbations to its base case values. As can be seen from the above example, any or all of allocations, demands, or efficiencles can be reset between perturbations.

At this point, all user entrles for a single perturbation have been completed. PERTURB informs the user of this and invites $\mathrm{hlm} / \mathrm{her}$ to continue on to a new perturbation or submit the current data set for execution.

THE IMFUT FEDUIFEMENTS FUF THIS FEFTIFEHT ILIT FEE

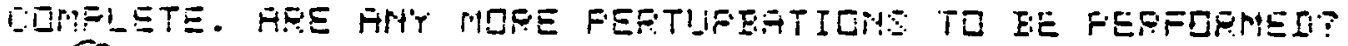

it

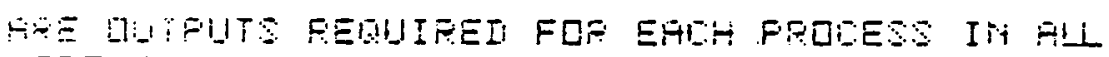

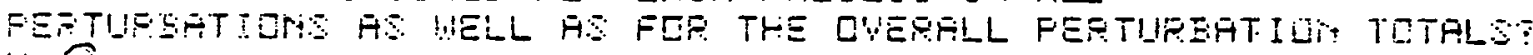

13

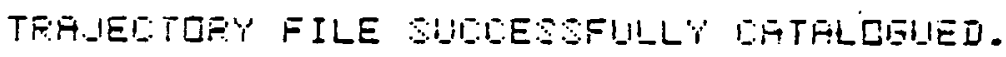

Unless the user answers " $Y$ " to the question regarding "outputs for each process" (s)he will receive only a sumary sheet of the analysis.

When the message "ANALYSIS IN IN PROGRESS" appears PERTURB has dispatched requests to MFZ for the actual execution of user data.

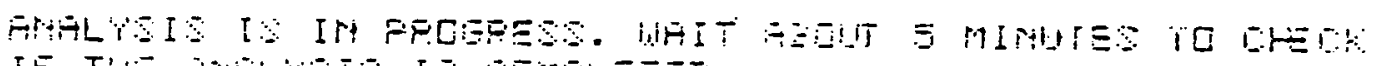

IS THE HULYT IS LUTELETEI.

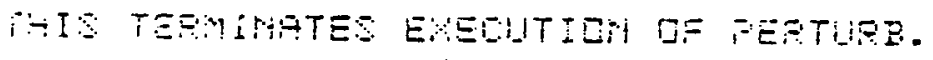

END FEFTIEE

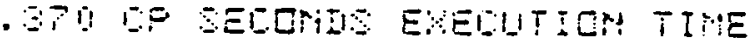

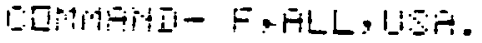

A joi can be tracked through the BNL system by the following command:

$F$, AIL, NY. (R) 
The response will look like this:

\begin{tabular}{|c|c|c|c|c|c|}
\hline & INPUT & OUTPUT & EXECUTE & PUNCH & JANUS \\
\hline \multirow[t]{2}{*}{ MFA } & 00013 & 00164 & 00021 & 00012 & 00002 \\
\hline & NONE & & & & \\
\hline \multirow[t]{2}{*}{ MFB } & 00024 & 00002 & 00011 & 00007 & 00001 \\
\hline & NONE & & & & \\
\hline \multirow[t]{2}{*}{ MFZ } & 00256 & 00019 & 00022 & 00000 & 00003 \\
\hline & & & NYESN6Z & & \\
\hline
\end{tabular}

The NYESN6Z is the name the system has asstgned this New York ESNS fob. The last 2 characters of this name will change each time PERTURB is run. When the job returns to the user's terminal (s) be can verify this fact by typing:

FIIES (R)

If the job has returned the response will be:

--LOCAL FILES -

* PERTURB

--REMOTE OUTPUT FILES--

NYESN62

At this point the user must dec1de how the output is to be produced (un paper or microfiche):

a) Type: BATCH, NYESN6Z, LOCAI. (R)

REWIND, NYESN62. (R)

b) to get output on paper type:

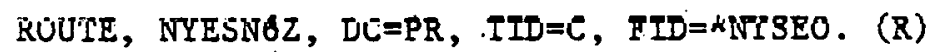

or

c) to get output on fiche type:

IDCARD, FICHE, \$NYSEOS, \$ESNSALI RUNS, PRFI.

COPY, NYESN62, FICHE.

RETURN, FICHE.

When the user is satisfied with the disposition of the output (s)he should type:

LOGOUT (R)

which ends the terminal session. 
The Disaggregated Data Base - System 2000

The data bases of the New York Energy Information System (NYEIS) are as follows:

1. NYS 1976 - statewide energy demand-supply information for 1976.

2. NYS 1985 - statewide energy demand-supply projected to 1985.

3. NYSDB - contains county and utility level information on the supply and consumption of energy within New York State for the year 1976

\section{System 2000 Design Considerations}

System 2000 portrays the data base in a hierarchical manner. As Figure 17 shows, the data is organized into groups which interrelate in a tree-structured (hierarchical) manner. The structure of the data base (i.e., its schema) is defined using System 2000's Define Module. The data definition language (ddI) categorizes the data into elements and repeating groups.

Elements are used for storing values, and can be of the types NAME, TEXT, INTEGER, DECIMAL, DATE or MONEY. Repeating groups specify which elements have multiple occurrences of data values and the relationships among elements in the hierarchy. The schema, in essence, is a data dictionary which describes the data elements and their relation-. ships to each other.

The data definition language structures the data base in a hierarchy (Table 38). In Figure 18 the structure for the statewide data base discussed in greater detail in Section IV below, is illustrated. The selected structure takes advantage of the efficiency of a hierarchy. A region could have an end use demand that uses two technologies. A mechanism is needed to link the technology to its end-use, sub sector and region. One approach would be to keep subsector and region information with each set of end-use and technology. However, the hierarchical structure approach ensures that sector and region information appears only once in the data base, thereby eliminating redundancy. The hierarchical structure links the end use and technology to its proper region and subsector. 


\section{DEFIHITIO:! TREE}

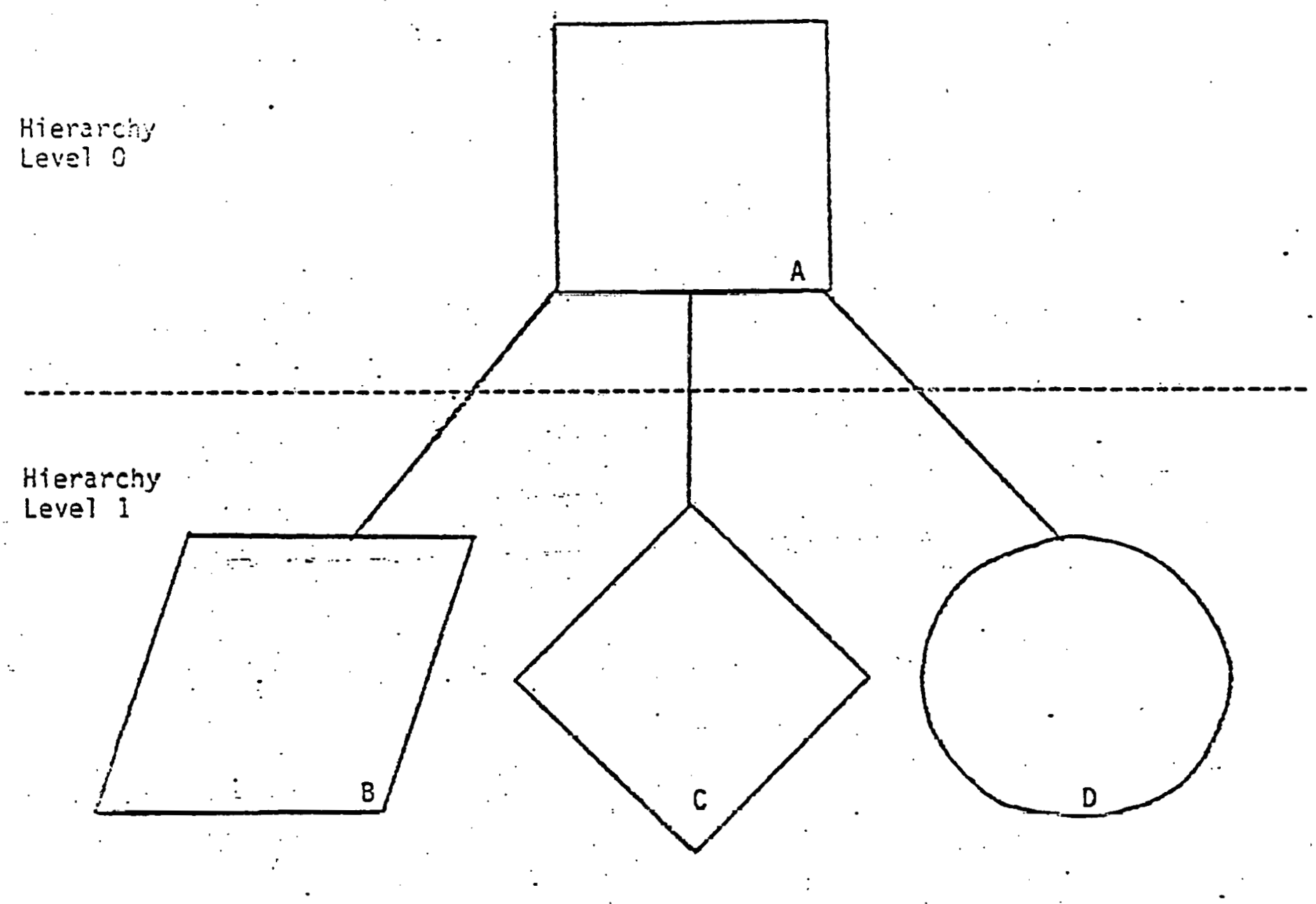

-The definition tree is the view of the data base that System 2000 sees:

- $A$ is the ancestor of $B, C$ and $D ; B, C$, and $D$ are the descendents of $A$.

$A, B, C$, and $D \cdot e r e$ repeating groups.

- $A$ and $C, F$ and $C, A$ and $D$ are families; $B, C$, and $D$ are in different ramilies and are called disjoint. $B, C$, and $D$ relate to one enother through $A$.

FIGIJR LI : SYSTEM 2000 Data Definition Tree. 
Table 38. Data Elements

$\begin{array}{ll}\text { Region } & \text { SubSector } \\ \text { Region Name } & \text { Region Name } \\ \text { Subsectors } & \text { Subsector Name } \\ & \text { End Uses }\end{array}$

End-Use

Region Name

Subsector Name

End Use Name

Technologies
Technology

Region Name

Subsector Name

End Use Name

Technology

Pollution Data 
Figure 18. Statewide Data Base Structure

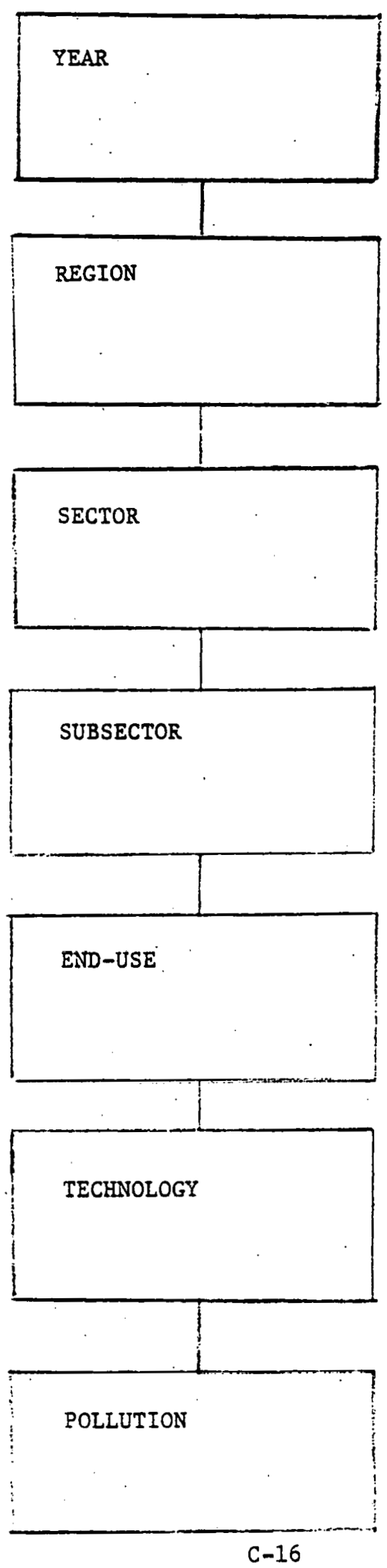


The detailed data base schema, Including the specific data elements, is presented in Figure 19. The records are primarily organized by year and region; each logical entry in the data base is for one region for one year and the assoclated sector, subsector, end use, technology and pollution data. To expand on this concept, lmagine Region $X$ has two sectors (one and two) each with two subsectors ( Gamma and Delta). Each of these subsectors has a cooking end use with Beta having a lighting end use as well. The logical entry for this Region for the year 1976 can be illustrated as in Figure 20, where the repeating groups sector, subsector and end use repeat for each set of data, while the common parent repeating group appears only once. This simple example, multiplied for each region forms the data base.

The NYSDB discussed more fully in Section. IV below, has a more complicated structure. Most of the data elements are independent of each other (Table 39). Because of this independence the data base structure contains many siblings for each hierarchy level (Figure. 21).

\section{Statewide Data Bases}

Two data bases were constructed to represent the 1976 and 1985 energy demands, NYS 1976 and NYS 1985. These data bases were constructed independently of ESNS. The fuel demands calculated within these data bases are the principal fuel demand inputs into ESNS, along with efficiencies and market allocations. (A detailed description of ESNS is included in Chapter II.)

Total demands for ofl and oll products, natural gas, coal and electricity are aggregated from spectfic demand in the residential, commercial, industrial, transportation, governmental and agricultural sectors of New York State. The electrical sector supplies electric energy to the six sectors 1 is ted above and requires fuel inputs already mentioned in addition to uranium and hydropower. The energy requirements of a small utility steam sector are considered as well.

Future energy demand is projected by considering the underlying determinants of demand--the energy services required and the efficiencies with which various fuels are used to provide those services. More 
Figure 19. Statew1de Data Base Definition Tree Structure

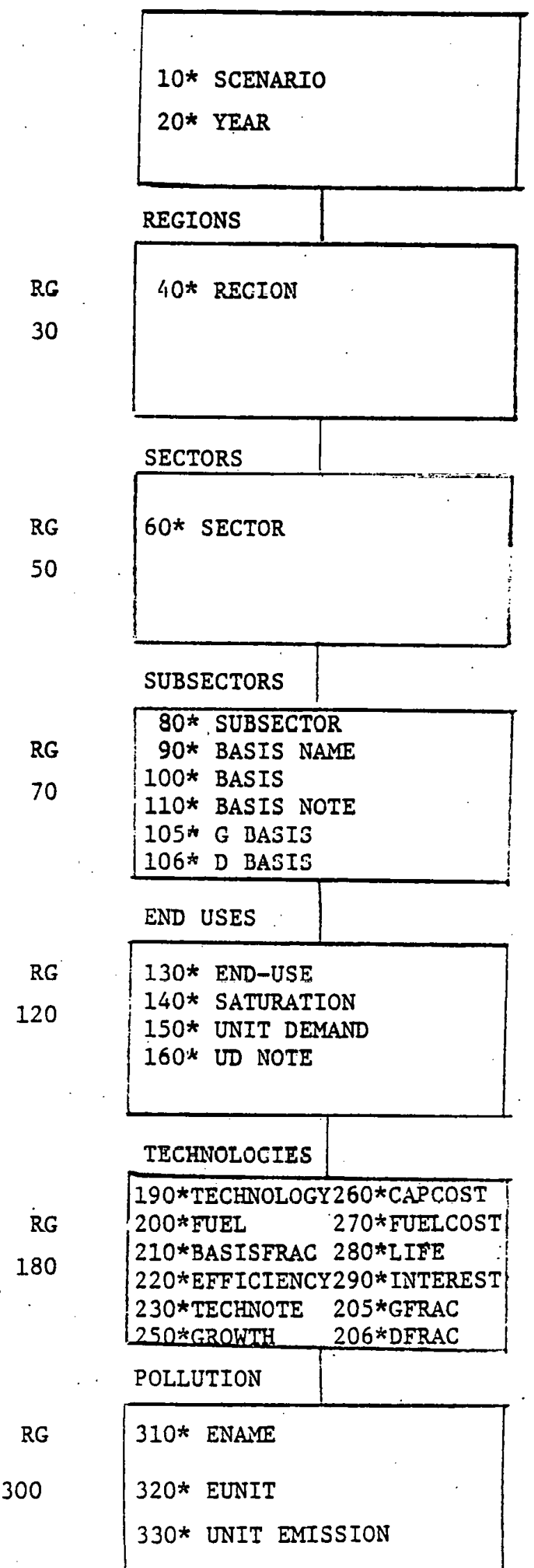


Eigure 20. Statewide Data Base -

Example of a Logical Entry

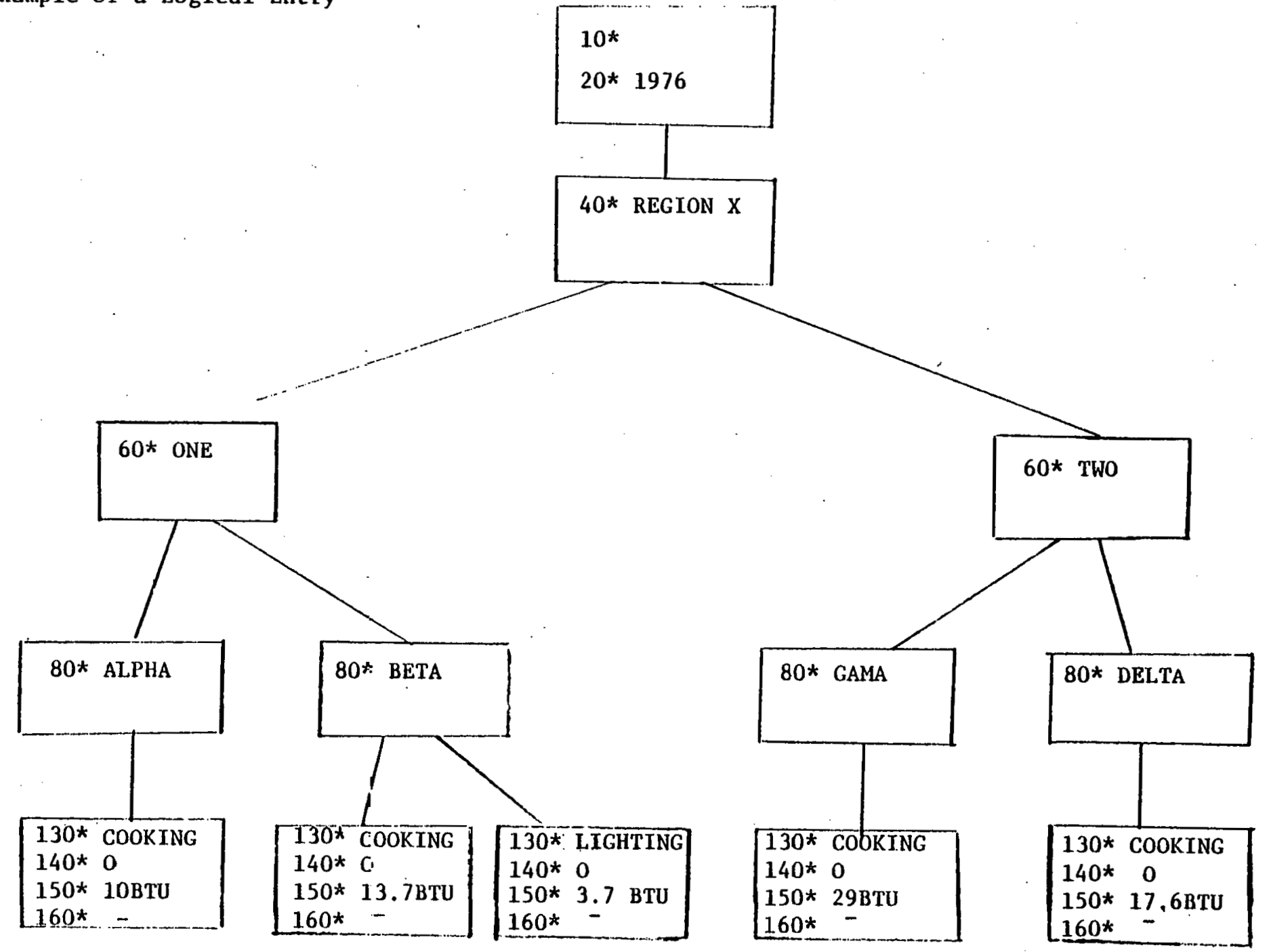


Table 39. Data Elements - NYSDB

$\begin{array}{ll}\text { Fuel Utility } \\ \text { Year } & \text { Year } \\ \text { Fuel Name } & \text { Fuel Name } \\ \text { Utilities } & \text { Utility Name } \\ & \text { Counties } \\ & \text { Supply data } \\ & \text { Resale data } \\ & \text { Power plant data } \\ & \text { Capacity data } \\ & \text { Notes } \\ & \text { Typical Bills } \\ & \text { Fuel data }\end{array}$

Power Plant Data

Power plant name

Unit data 
Pigure 21.

Tree Structure for NYSDB

$$
\begin{aligned}
& 2 * \text { YEAR } \\
& 3 * \text { FUEL } \\
& 4 * \text { UNITS OF DEMAND } \\
& 5 * \text { UNITS OF POLLUTION } \\
& 8 * \text { UNITS OF DEM COST }
\end{aligned}
$$

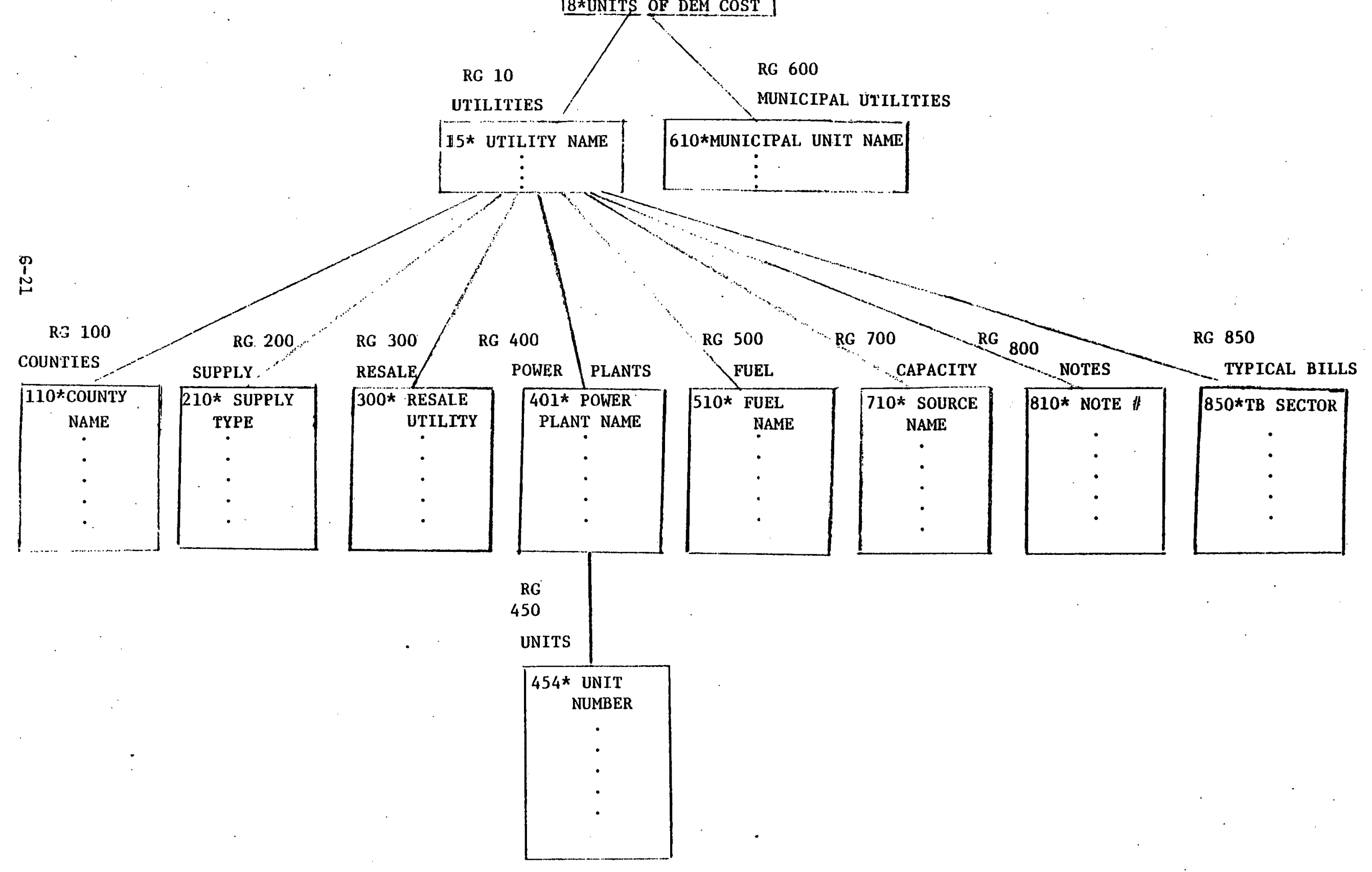


explictily, the data listed below are 1ncluded under the following headings.*

1. Subsector

2. Basts

3. Fuel Demand

4. Total Fuel Demand

5. Relative

System Efficlency

6. Degree of Saturation for example, in the transportation sector, passenger or freight, or in the restdential sector, single famfly or high-rise dwellings.

B, a profection variable which conventently characterizes change in the subsector; for example, in the commercial sector the principal determinant of energy use is the amount of floorspace.

$D_{i}$ is the quantity of a fuel, 1 , actually consumed in a specific demand category, such as residential space heating or commercial air conditioning.

$D_{s}$ is the total fuel required to satisfy the requirements of a specific demand category. Electricity is considered as a fuel in this sense and $D_{s}=\sum_{i} D_{i}$. $a_{i}$, is the relative effectiveness with which fuel, 1 , is used in a demand category. This parametus depends on the uttilization technology employed. For space heating, $e_{1}$ for other structures are given in the fuel mix tables.

$S$, is the fraction of the potential demand for a particular energy use actually being fulfilled at a given time. For example, $1195 \%$ of all households have refrigerators and the potentlal demand for refrigeraturb Is taken to be one per house, $S=0.95$.

* This information was included in Chapter 2 in the discussion of the RES but is repeated here for convenience. 
7. Unit Energy $E_{u}$, is the amount of energy per unit that Demand would be required for a specticic end use, assuming a relative system efficiency, $e_{i}$, of $100 \%$ for each fuel employed. Thus, for a given end use, the actual fuel demand per unit is $E_{u} / e_{1}$, where $e_{1}$ is the actual relative system efficiency.

8. Technology $f_{1}$ is the number of energy consuming units Fraction satisfied by fuel $1 . \sum f_{1}=S \cdot B$

By specifying the technology fraction, $f_{1}$, and relative system efficiency, $e_{i}$, the fuel demand $D_{i}$, can be derived by the equation:

$$
D_{i}=E_{u} \times f_{1} \div e_{1}
$$

NYSDB

The NYSDB which contains county and utflity level information on the supply and consumption of energy within New York State for the year 1976 utilizes the System 2000 data management package. The five primary fuels analyzed were coal, electrictty, natural. solid waste, gas, and petroleum. Details included for each fuel are listed below.

For coal:

1. Supply.to a region by truck, rail or water

2. Consumption of bituminous coal by county for electric demand, industry, coking and others.

3. Consumptiun of anthracitc coal by county.

4. A l1st of counties that have coal delivered by rail.

For electricity:

1. Average cost to the consumer of electricity by utility or county.

2. Consumption of eleçtricity by residential, commercialindustrial or public authorities by county or utility.

3. Pollution generated by power plants or utilities.

4. Fuel consumed by power plants or utilities. 
5. The New York Power Pool Report listing. Individual generating station capability.

6. Capacity and generation by utility.

7. Typlcal bills for each uttlity.

8. Transactions among utilitfes.

For natural gas:

1. Average cost to the consumer of natural gas by utility or county.

2. Consumption of natural gas by residential, commercialIndustry or public authorities by county or utility.

3. Quantity supplied and cost of natural gas to utilities by type of transportation and company.

4. Quantity resold by one utility to another.

5. A list of counties that do not have access to natural gas.

6. Quantity of natural gas which is interruptible, firm, lost stored and internal use by utility.

For petroleum:

1. Consumption of petroleum by restiential, comercial and transportation sectors by county and utility.

For solid waste:

1. BTU equivalent of solid waste generated by each county within an SMSA.

Using. System 2000

There are two ways to retrteve data from the data lase:

1. Naturai Language

2. Report Writer

Natural Language is System 2000's English-like, interactive query language (see discussion below). Report Writer is a module which permits the user to compose and generate formatted reports. 


\section{Retrieval}

Natural Language has two modes: Immediate Access and Queue Access. Immediate Access is orfented toward interactive use at a remote terminal, and provides data manipulation, analytic, update, and some formatting options. Queue Access is similar in syntax to Immediate Access, but is oriented toward processing a series of related transactions in a batch mode.

The basic form of Natural Language command consists of an action clause, and a where clause. Action comands include PRINT, LIST, TALIY, $A D D$, etc. The WHERE clause follows the operation or action section of a command, where the action may. be retrieval or updating of data. For example, referring to Flgure 4, imagine that Region $X$ is one of a number of Regions with a cooking end use. To retrleve a list of all regions with a cooking end use from the data base one would structure a command such as :

\section{LIST REGION WHERE END USE EQ COOKING \%}

Since System 2000 will recognize both the names and numbers of data elements the following command will be equivalent to the one above:

\section{LIST C40 WE C130 EQ COORING \%}

In addition to EQ, WHERE clause elements can be qualified with operators such as NE (not equal), GT (greater than), GE (greater than or equal to), LT (less than), LE (less than or equal to), SPANS (ranges of values), FAIIS (value does not exist), and EXISTS (value does exist). Boolean Processing enables the user to relate the conditions with AND, OR and NOT, and with the HAS operators, to permit data in one hierarchical level to be qualified based on properties of data on another level. . IF...THEN... ELSE... logic is possible in Queue Access.

The system functions of COUNT, SUM, AVERAGE, MAXIMUM, MINIMUM, and SIGMA (standard deviation) are built-in arithmetic commands. For example, to compuce the average End Use dcmand for cooking hy all Regions we issue the following command:

\section{PRINT AVERAGE UNIT DEMAND WHERE END USE EQ COOKING \%}

Again the component number can be substituted giving the following equivalent command: 
Under-defined retrieval functions can be specifted to supplement the system functions of COUNT, SUM, AVG, etc. These functions can be defined, stored in the data base, and then spectffed during a retrieval command.

The String capability allows the user to name and define a very complex or frequently used serfes of commands and store this string in the data base. Then, by simply typing the name of the string, System 2000 will automatically execute the commands.

Updates can be made in either the Queve or Immediate Access modes, depending on the size and nature of the updates. Updates can be qualified with a WEERE clause.

\section{Examples of Apolications}

To familiarize the reader with the use and capabilities of the data base this section presents excerpts from terminal sessions which show examples of System 2000's Natural Language. After phoning in to the Brookhaven Intercom you will receive the following message requesting you to Login:

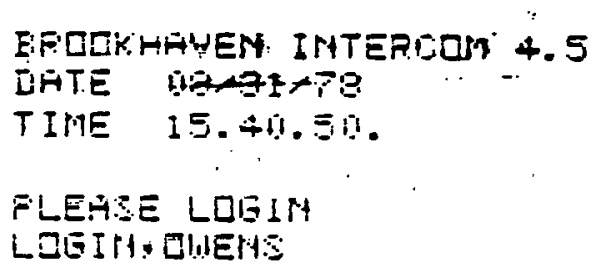
Your PROBLEM NUMBER

The computer will then $10 g$ you in and type the day's SYSBUL as shown above. 
When the SYSBUL is finished printing you will be prompted by the printing of the word COMMAND -

EDMMARD- RTTREH. SEK. HESFILE

fF EYLLE HO: $=$ MOH

ECMMAHID - ETL. 500

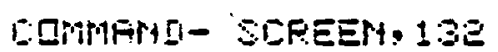

COMMARD- SEK:

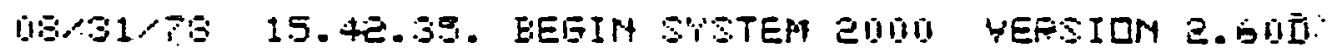

$-2-1$

USEF-HTSEQ\%

$-\infty$

DEH IS HYS

-ESB- ASIIGIED

HYS1:385

$\ddot{B}$

$5003 / 15 / 78$ 10.45-5อ.

ATTACA, S2R, ABSFIL 6 - Brings the SAR software program to you.

ETL, 500

- Ops your CP time.

SCREEN, 132

- Allows your terminal 132 characters per Iine.

$S 2 R$

- Calls for your entry into S2K.

USER, NYSEO\%

- Puts you in control of your data bases.

DBN IS NYS1985\%

- Asks for access to the NYS1985 data base

We are now ready to retrieve information.

$-==$

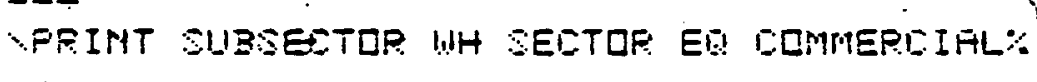

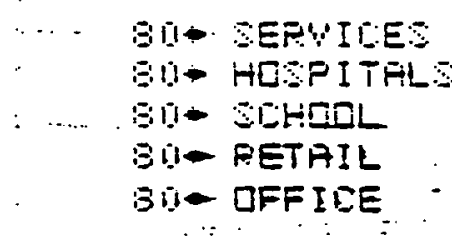

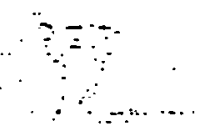

$\therefore \because$

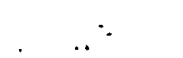

This Command returas the five subsectors under Commercial. 


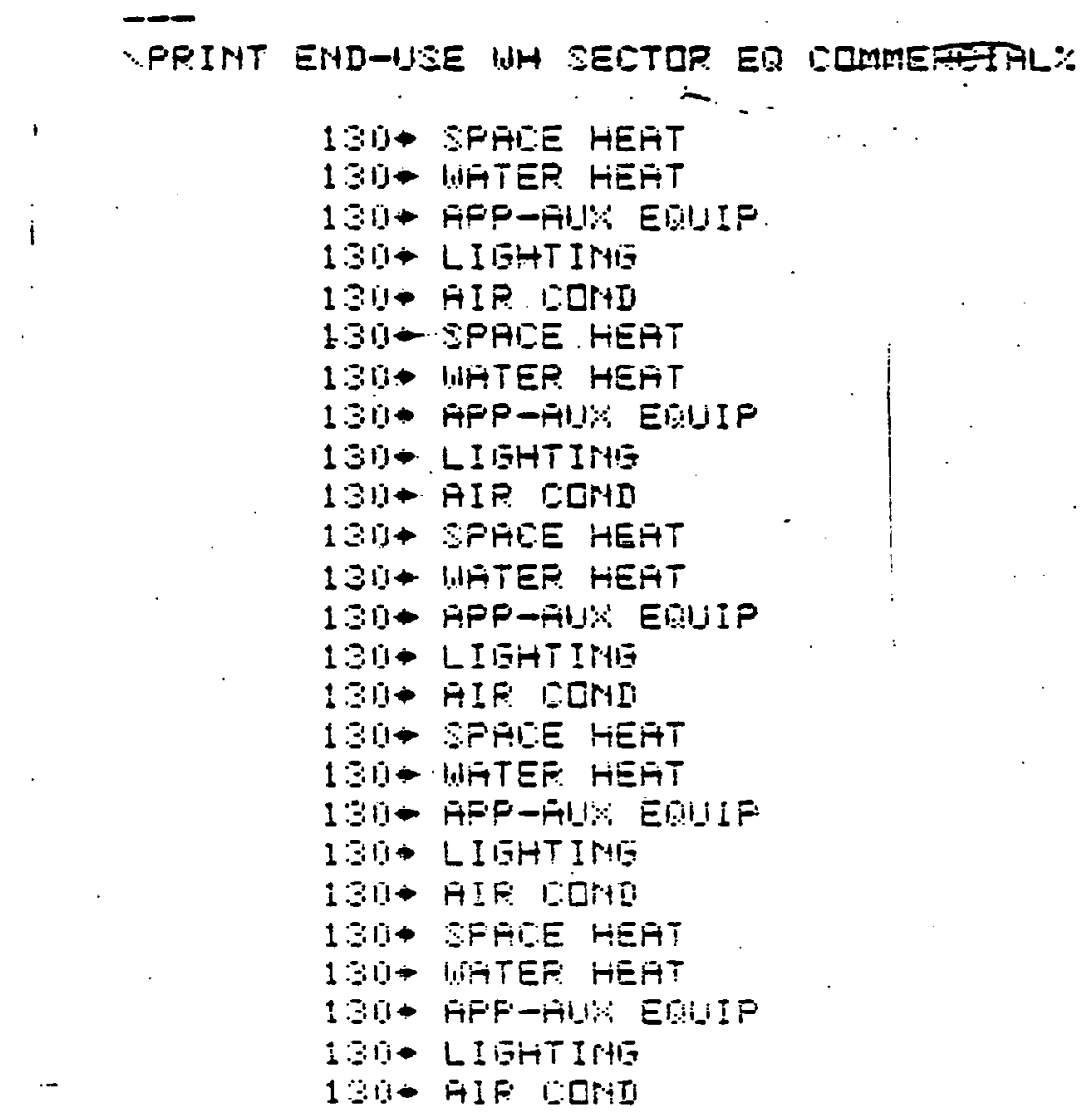

Th1s command returns all END USES that have commercial as their sector.

These END USES are repeated five times, once for each of the subsectors under commercial.

If we wished to look at the END USZS and UNIT DEMANDS of one subsector we would use the following command:

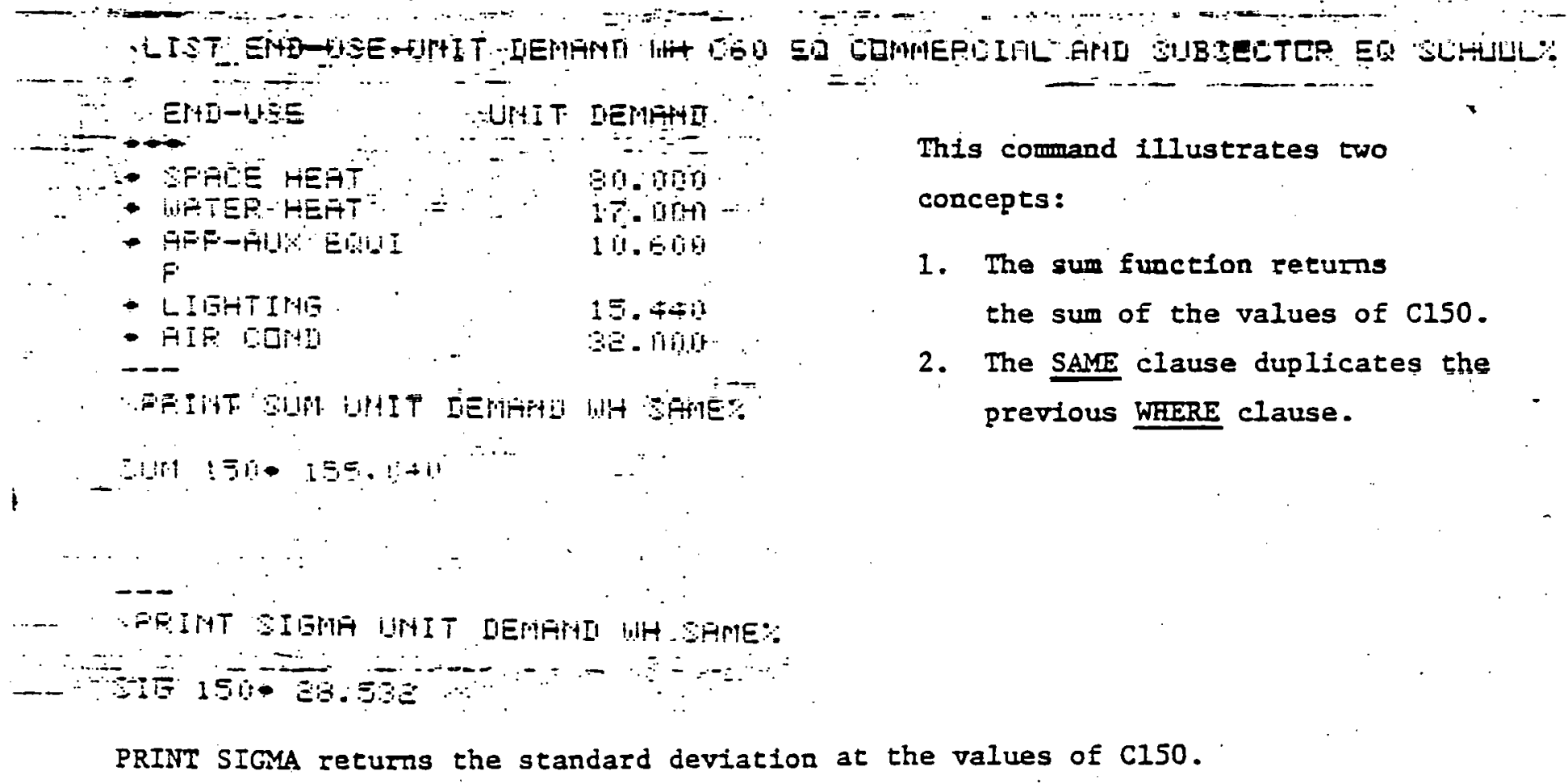


UPDATING

To change the current yalue of a data element the CHANGE command is used

VHAMGE C15D EQ 3e. DU1 - WH SAME AHD EHIJ-USE EG RIR GQMD\%

- 1.. SELELTEI IFTA SETS: -

DFEIHT-CISD WHH SAPE\%

1500 : 23.001

- 1 SELECTED DATA SETS - This Informs us that only one data set satisfled the WHERE clause.

The PRINT comand verified the change.

If we wish to execute any of the reports listed in Appendix

we simply give the command for that report.

$\rightarrow$ PELLUTIOH

$\because$ SETCF

IE

PULLIJTAHTS FFOM THE COMEUSTIOH QF FOSEIL FUELS. CTORS

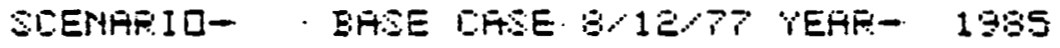

ABFIOULTIFE

DOMEFIIFL

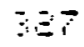

29, 192 94,

4.93

30.573

3,410

$41 \cdot 433$

BDEFHEHT

$$
413 \quad 1.51
$$

85

60

545

57

อง:

MEHLEALTUEIHE 07

78,100

$45 \cdot 239894$

3 ำำ

4,700

1. 4290912

ละง 5อง

FEOIEMTIAL 280

21,015

97:751

5024

B. 19

12,157

$50.551 \quad 50.709$.

TFATAFOFT

56

54.55

$401 \cdot 690 \quad 3 \cdot, 241$

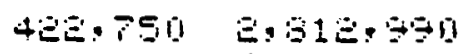

$25.502 \quad 71.348$

ITFL

อ15.142 573.65

$209+5134$

4.7.

$1.5 \div 2.5 \% 1$

$194,650$. 
The above report writes more than 72 characters per line. If we wish we can write the above report to a local file which can be sent to a line printer when we return to INTERCOM .

WEFERT FILE IS AHPTHAME:

This command wil wite the next

PFLLUTIDH and ALL FUTURE commands output to local file ANYNAME.

A copy of the Report *POLLUTION* is now in local file ANRAME and could be printed after leaving $S 2 R$.

We cān change data bases hy entertng the rnNMROL MODE and giving the command DATA BASE NAME IS.

DEMTFIL

IIETt IS HYOE:

-505- DLOSED HYISE

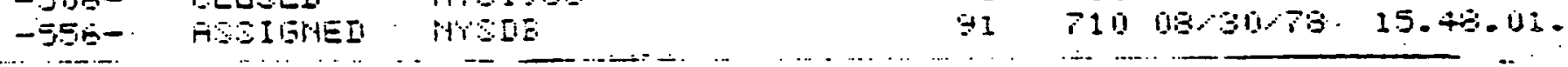

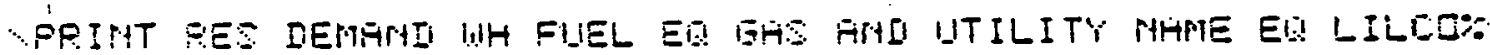

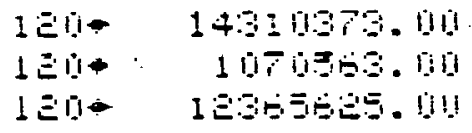

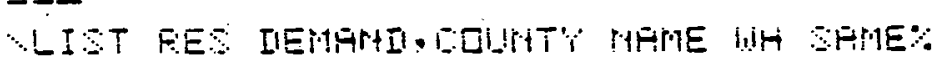

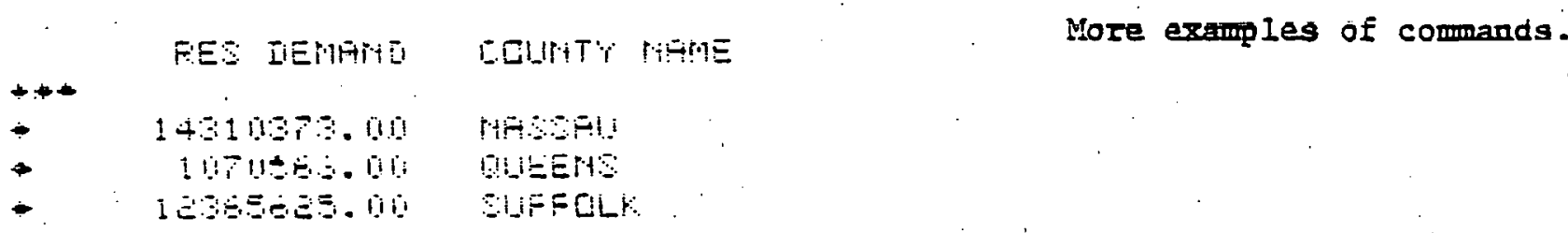


$-\infty$

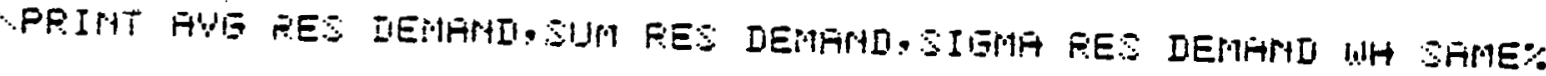

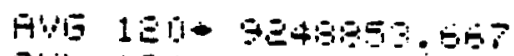

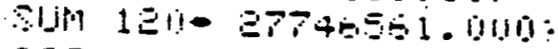

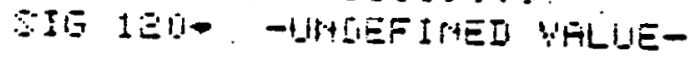

Calling for execution of report.

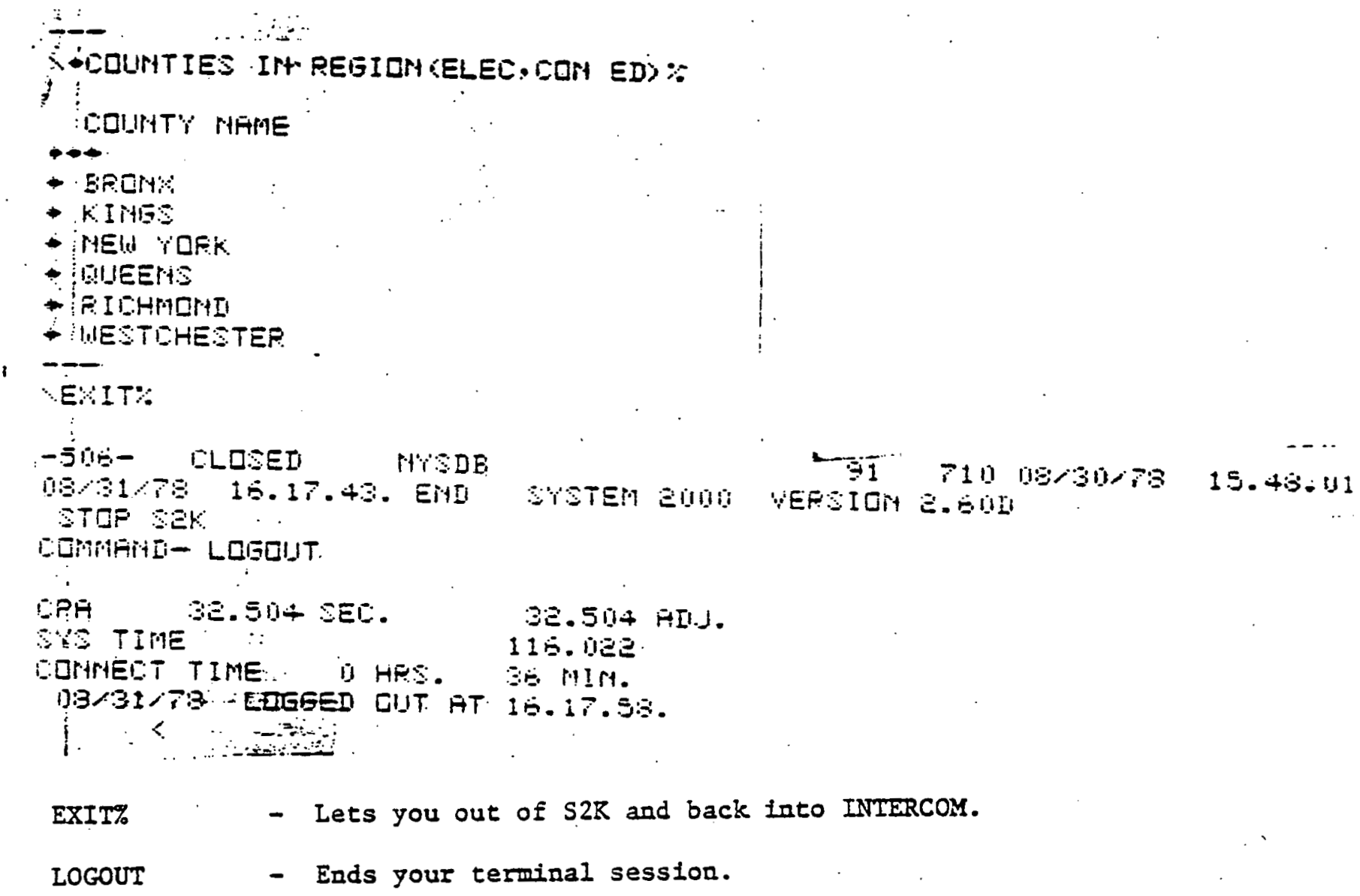




\section{NYS Temperature Senstitive Energy Demand Model}

In Chapter 2 we described the temperature sensitive energy demand model in the paragraphs which follow we describe the actual operation of the computerized model. The section starts with a brief review of required inputs and outputs of the model and concludes with a typical computer run.

\section{Region Definition}

Thie sixty-lwo New York State counc1es were grouped into six regions based on three factors--primary utflity serring the sounty, twonty-nine heating and cooling degree day normals, and geographical proximity. The first was of concern due to the use of utility-based data, and usually coincided with the third. The least varlance in the degree day normals was chosen within this constraint.

\section{Inputs to the Program}

The program requires the following data:

1. Target year

2. Region (or entire state for which fuel demand change is to be computed)

3. Change in the number of cooling and heating degree days for the region(s) to be considered

\section{Qutput of the Program}

The user obtains the following information:

1. "The housing mix and commercial floorspace for each of the end-uses, by subsector and fuel

2. Fuel efficiencies used

3. Change in fuel demand by sector and fuel

\section{Options of the Program}

1. County names. The names of the counties in each of the six regions are stored in the computer program's data base and can be recalled at the user's command when running the model. (They are listed in Table 16). 
2. Changing the basic vartables, The basic numbers $\left(N_{1 j 1}^{t}, M_{1 j 1}^{t}, F_{11}\right.$, $\left.G_{i 1}\right)$ * can be altered by the user. This option allows the user to study the effect on change in fuel demand of alternate fuel mixes in the residential or commercial subsectors, alternate saturations of air conditioning, and alternate projections of the basis vartables. Any of the basis varlables can be changed; Instructions for the change command sequence are stored in the program. .

3. Region. The user can study fuel demand change for one of the six regions in the state, or the entire state in one run of the program. If the latter option is chosen, the program will print out four tables containing the basis varlables - space heat housing mix, alr conditioning, housing mix, space heat commercial floorspace, and air conditioning commercial floorspace - for each of the six regions, for a total of 24 tables. This large output can be suppressed by the user, as shown in the attached sample run. Each of the end-use table types can be suppressed individually. The calculation of the change in fuel demand in all four end-uses will take place irregardless of the output suppression chosen. This is a useful option for studying the effect of a fuel demand change when altering the expected change in degree days while holding the basic variables constant.

4. Iterative runs. The program can be run repeatedly at the user's option. A command at the end of the program allows the calculation of fuel demand change to be re-computed, using the same values of the basic variables and fuel efficiencies as on the previous run. Thus, once changes are made on the basis variables stored in the program for the entire state (or one region), the user can study the effect on fuel demand change of further altering fuel efficiencies or basis variables, or entering different values for the heating and cooling degree day changes.' Output suppression and change commands are allowed on 1terative runs.

5. Fuel efficiency changes. Alternate scenarios providing for more efficient end-use demands can be tested in the program to study their effect on change in fuel demand. The fuel efficiencies stored in the program have been listed above; they can be changed by the user. (See Chapter 2).

*These variables are defined in Chapter II. 
SAMPLE PROGRAM RUN: NYSEIS WEATER MODEL

A sampie run on the NYSEIS Weather Model follows (page). It shows the commands necessary to run the program from the BNL Computer System, after logging in. All user entrles are shown in either number or lower-case letters, typed after the proupting symbol "->"

The options the user has chosen are listed below.

1. A " 1 " has been' entered, causing the program to display the main instructions.

2. The targer year chosen is 1978 .

3. The user has chosen to suppress comercial sector floorspace output by typing an "r"

4. Within the residential sector output to be shown, the user has chosen to see both end-uses by typing "bo"

5. The user has chosen to list the counties in region 6 by typing "6."

6. The user has chosen to change the fuel efficiencies in the residential sector by typing "r"

7. The user change the residential sector, air-conditioning end-use, central air conditioner type by entering " $6,2.50 "$

0. The user has chosen to compute the change in fuel demand for region 6 of the state by typing "6"

9. The user has chosen to display the change command instructions by typing "2"

10. The user has changed the residential housing mix, air conditioning , end-use, central air-conditioning type, single family subsector to 50000 units by typing " $r, a c, 2,1,50000 . "$

11. The user has chosen to enter a second change command sequence by typing " 1 "

12. The user has changed the residential housing mix, space heat end-use, oil fuel type; high rise subsector, before 1970 construction, by typing the sequence " $r, s h, 2,8,900000$." 
13. The user has input a change of 100 heating degree days for the year 1978 in region 6 by typing "100"

14. The user has input a change of 100 cooling degree days for the year 1978 in region 6 by typing "100"

15. The user has chosen to make an iterative run by typing " $r$ "

16. The user has chosen to suppress all output of the basis variables by typing " $\mathrm{n}$ "

17. The user has chosen to keep the fuel efficlencies as altered in the previous run by typing " $x$ "

18. The user has chosen to make a further change on the residential housing mix by typing " 1 "

19. The user has chosen to change the residential sector, oil fuel type, single family subsector, built after 1970 , to 90,000 by typing "r,sh, 2,1,90000."

20. The user has entered a change in heating degree days of 1000 by typing "1000"

21. The user has entered a change in cooling degree days of 1000 by typing "1000"

22. The user has exited the program by typing " $n$ ",

\section{USER ERRORS IN EXECUTING PROGRAM}

The typical run (below) includes probable user errors and how to correct them. The first example shows entry of an invalid target year, and the program's response. The second example shows entry of an invalid output suppression command, and the program's response. The third example shows entry of the letter " $x$ " for the region number to list the county names, and the program's response. Note that the error message was different than that which occurred after the first two sample mistakes. The user typed a "O" immediately following the word "field" in the error message. The fourth example shows entry of an invalid efficiency change command. 
The fifth and sixth error examples show mistakes which can be made when entering change command sequences on the basis variables. The fifth example shows the input of an incorrect end-use which is more than two letters. The user retypes the line after the error message word "field", starting with the row of table data, not at the beginning of the line. The program responds with an error message, and the user re-enters the entire change command sequence. The sixth example shows the input of an 1ncorrect two letter end-use--"ad". The program responds with an error message, and the user re-enters the entire line. 
Monthly Heating and Cooling Degree Day Nommals, 1941-1970, (Source (7))

\begin{tabular}{clcccc}
\hline $\begin{array}{c}\text { Region } \\
\text { Number }\end{array}$ & Region Name & $\begin{array}{c}\text { Mean FDD } \\
\text { (county) }\end{array}$ & $\begin{array}{c}\text { Varlance } \\
\text { HDD }\end{array}$ & $\begin{array}{c}\text { Nean CDD } \\
\text { (county) }\end{array}$ & $\begin{array}{c}\text { Variance } \\
\text { CDD }\end{array}$ \\
\hline 1 & Adirondacks & 8,241 & 538 & 281 & 106 \\
2 & $\begin{array}{l}\text { Hudson River } \\
\text { Valley }\end{array}$ & 6,458 & 504 & 599 & 146 \\
3 & Central & 7,422 & 329 & 324 & 64 \\
4 & Great Lakes & 6,802 & 361 & 493 & 79 \\
5 & Finger Lakes & 6,910 & 379 & 451 & 142 \\
6 & Metro New York & 5,307 & 315 & 792 & 182
\end{tabular}

The Mean EDD was calculated by averaging all the 29-year normals for aach county in tie region. The variance HDD reperesents the variance II those noreais about the mean.

The mean CDD was calculated by averaging all the 29-year normals for each county in tire region. The variance CDD represents the variance of shose normals ajout the mean.

HDD = heating degree days

$\operatorname{CDD}=$ cooling degrae days 
Note: All User entries are in lower-case letters

COMHAND- attach, wftn, waatherftn, id=nyseo

PE CYCLE NO. = 001

COMIAND- screen, 132

COMMAND- wEt ${ }^{\circ}$

HELLO, THIS IS THE NYS ENERGY SYSTEM WEATAER MODEL , -

TYPE 1 . IF INSTRUCTIONS ARE NEEDED

OR O TO CONTINUE PROGRAM

(1) $\rightarrow 1$

EUIRZOSE OE TEE PROGRAM

TEIS PFOGRAM CALCULATES TEE CHANGE IN FUEL DEMAND IN THE RESILENTTAL AND COMMERCIAL SECTORS, DUE TO A VARIATION IN WEATEER PATTERNS ACROSS TEE STATE.

\section{METIZOD OE THE PROGRAM}

HOUSING STOCA FOR 1970 IS PROJECTED TO THE TARGET YEAR IN WAICE EUEL DEHAND CEANGE IS TO BE CALCULATED, US ING GRONTE RATES STORED IN TEE PPOCRAM. THE STOCR IS BROKEN INTO SIX REGIONS, FOUR HOUSING TYPES, AND TINO END USES.

COMSREIAL ELOORSPACE FOR 1975 IS PROJECTED TO THE TARGFT YEAR IN GHICH FUEL DELAND CHANES IS TO BE CALCULATED, USING GROFTH RATES STORED IN TIE PROGRAM. TEE ELOCRSPACE IS BROKEN INTO SIX REGIONS, EIVE SUBSECTORS, AND THO END USES.

TUE AMOUNT CE ELOORSPACE AND THE NUMBER OE HOUSEEOLD UNITS IN EACH CLASS IS TEEN MULTIPLIED BY THE CHANGE IN THE NUMBER OE DEGREE DAYS FOR EACH REGION, DEGREE DAY-HOUSING TYPE FACTORS, AND ENERGY EEEICIENCIES TO DETERMINE TEE CBANGE IN EUEL DEMAND FOR THE REGION.

YNTUTS TO TEE PROGRAM

THE CRANGE IN THE NUHBER OF COOLING AND HEATING DEGREE DAYS BOR EACH REGION OF THE STATE, AND THE YEAR WHEN THE CHANGE IN EUEL DE:IAND VIILL BE COMPUTED (1975-1985).

OPTIONS OE TEE PROGRAM

(1) UIST TEE COUNTIES IN EACA REGION $\cdots$

(2) CLANEE TEE HOUSING MIX OR THE FLOORSPACE IN EACY REGION EOP. TEE TARGET YEAR

(3) CONSIDER EUEL DEMAND CHANGE IN ONE REGION

(A) CO:ISIDER EUEL DE:AAND CHAINGE IN THE ENTIRE STATE

(5) RUN TEE PROGRA:S ITERATIVELY, REUSING THE HOUSING WIX OR ELOORSPACE AS IT WAS CHANGED TI TEE PREVIOUS RUN

(5) CRANGE THE EEEICIENCIES USED TO CALCULATE CHANGE IN ETEL DEMASD 
Sampie ineather Model Dutout - Page I

Note: All user entries are in lower cass letters, all comments are underlined

REGIONS OF THE STATE

<I> ADIRONDACKS

<2> HUDSON RIVER VALLEY

〈3〉 CEITRAL

〈4〉 GREAT IAKES

<5> FINGER LARES

$\langle 6\rangle$ METRO NEW YORK

TYPE THE TARGET YEAR AS XXXX

- $\rightarrow 1978$ 
Sample weatiner Model Outout-Page 2

OU'EUT OF THE RESILEITIAL HOUSING MIX AND COMMERCIAL FLOORSPACE

CAN BE SUFFRESSED. CAICULATION OE CHANGE IN FUEL DEMIAND EOR BOTU SECTORS WITL BE DONE, AND DISPLAYED.

TYEE R TO SEE ONLY RESIDENTIAL HOUSING STOCK

C TO SEE ONLY COMEPCIAL ELOORSPACE

B TO SEE BOTH FLOORSPACE AND HOUSING STOCK

(3) $\rightarrow r$

N TO SUPDRESS ALL OUTPUT

RESIDENTIAL ECUSING STOCK NIIL BE SEONN

TYFE AC TO SEE ONLY AIR COND EOUSING MIX USED IN THE PROGRAM SH TO SEE ONLY SFC HEAT HOCSING MIX USED IN THE PRCGRAM 2O TO SEE BOTH EOUSING MIXES USED IN THE PROGRAM

(A.) $\rightarrow$ bo AC TO SUTERESS OUTLUT OF BOTI BOUSING MIXES

EO HCUSING MIX(ES) MIIL BE SECN

TYYE THE REGION NUABER $(1-6)$ TO IIST TEE COLNTIES IN A REGION (5) $\stackrel{C R}{\rightarrow} 6$

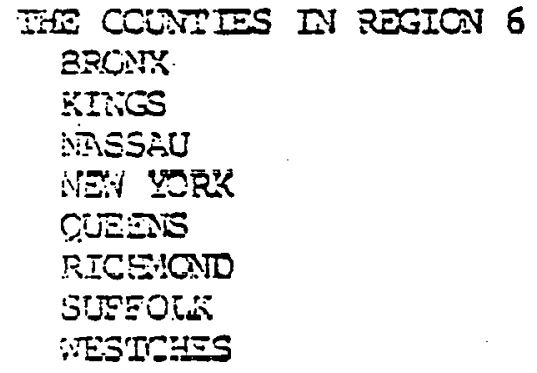

TYFE TAE REGION NTWBER (I-5) TO LIST THE COUNTIES IN A REGION CR O TO COVTIIUE DPOCRAM

$\rightarrow 0$

TPE R TO CAAHE RESIDENTIAL FUEL EFEICIENCIES

C TO CLANG CCMERCIAL EUEL EFETCIENCIES

D TO DISPLAY FUEL EREICIENCIES USED IN PROGRAH

$X$ TO CONTTIJE PROERAM

(5) $\rightarrow r$ 
Saniole Neaciar Hadel Outout - Page 3.

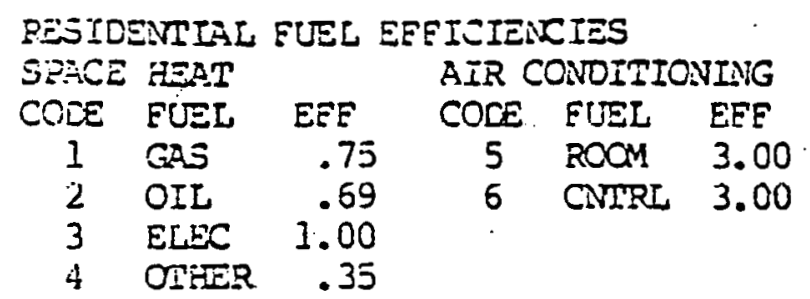

ENTER CODE, NEN VALLE OE EFEICIENCY

$\rightarrow E, 2.50$

TUPE $R$ TO CEANE RESIDENTIAL FUEL EEFICIENCIES

C TO CHANE COMMERCIAL FUEL EFFICIENCIES

D TO DISPLAY FUEL EEFICIENCIES USED IN FROCAA4

$X$ IO CONTIIUE PROGRAiA

$\rightarrow x$

\begin{tabular}{|c|c|c|c|c|c|}
\hline \multicolumn{6}{|c|}{ STACE HEAT } \\
\hline $\begin{array}{c}\cos 2 \\
\frac{1}{2} \\
2 \\
3\end{array}$ & $\begin{array}{l}\text { EJEL } \\
\text { GAS } \\
\text { OIL } \\
\text { EIEC }\end{array}$ & $\begin{array}{l}\text { EEE } \\
.75 \\
.69 \\
1.00\end{array}$ & $\begin{array}{c}\text { CODS } \\
5 \\
6\end{array}$ & $\begin{array}{l}\text { FUEL } \\
\text { ROOM } \\
\text { CWIPLL }\end{array}$ & $\begin{array}{l}E F E \\
3.00 \\
2.50\end{array}$ \\
\hline$\dot{q}$ & OTEER & 3 & & & \\
\hline
\end{tabular}

OAMECIAL FIEL EFFICIEXIES

\begin{tabular}{clcccc} 
SPACE HEAT & \multicolumn{4}{c}{ AIE CONDITIONING } \\
SOCE EUEL & EFE & COLE & FUEL & EFE \\
1 & OIL & .52 & 4 & ELEC & 3.00 \\
2 & OAS & .53 & 5 & GES & 1.80 \\
\hline & STEAM & .55 & & &
\end{tabular}

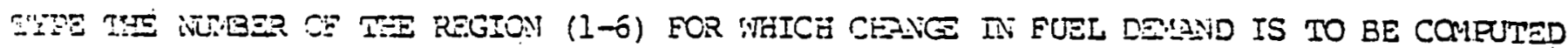

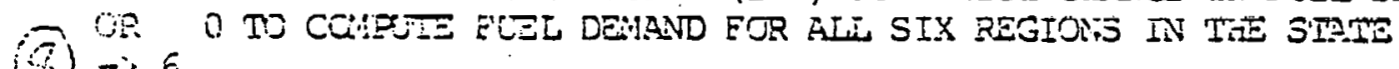
(3) $\rightarrow 6$ 
NOTE: HOUSING MIX \&/OR FLOORSPACE DATA IS USLD TO COMPUTE FUEL DEMAND CHANGE THE HOLSING MIX \&/OR FLOORSPACE FOR MHE REGION(S) CHOSEN IN THE YEAR 1978 78

SPACE HEAT HOUSING MIX, REGION 6 (NO, OF HOUSEHOLDS)

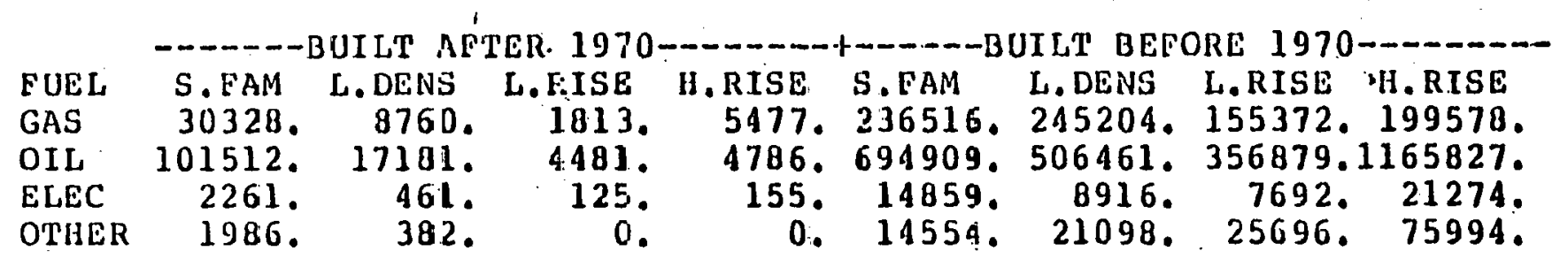

Air CONDITIONING HOUSING MIX, REGION 6 (NO, OF AIR COND UNITS) ..

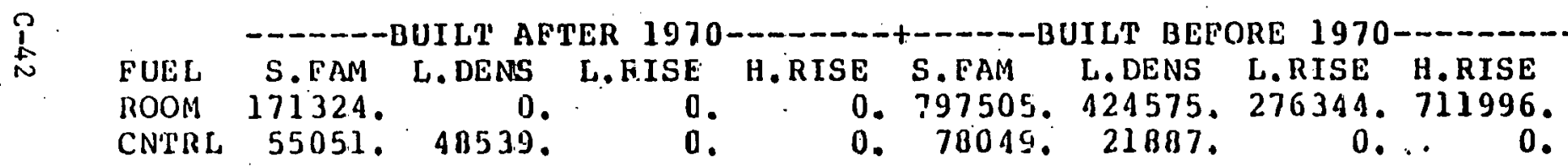

TYYPE 2 TO DISPLAX INSTRUCTIONS ON HOW TO CHANGE THE VARIABLES ABOVE

1 TO ENTER CHANGE SEQUENCE ON ELOORSPACE OR HOUS ING MIX

(9) $\rightarrow 2$ 
ANY CE TEE VALUES TA THE RESILENTIAL AND COMEXCIAL SECIORS, EVEN IF TTEY ARE NOT FRTINED OUT ABOVE, CAN BE CHAAVED IN THIS PART

OF TIE FEOGRAY. AISO, EITIER END-USE IN THE SECTORS CAN BE CHANEED.

A STRING OE CODES IS NEEDED TO CHANG THE VALUES. TUEI ARE LISTED BELON:

MHE: DOING THE ENTIRE STATE-

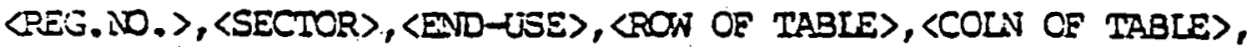
〈REZLACENENT VALUE〉<.> INTEN DOING ONE RDGION-

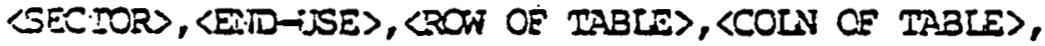
SPELACENERT TACUE〉<.>

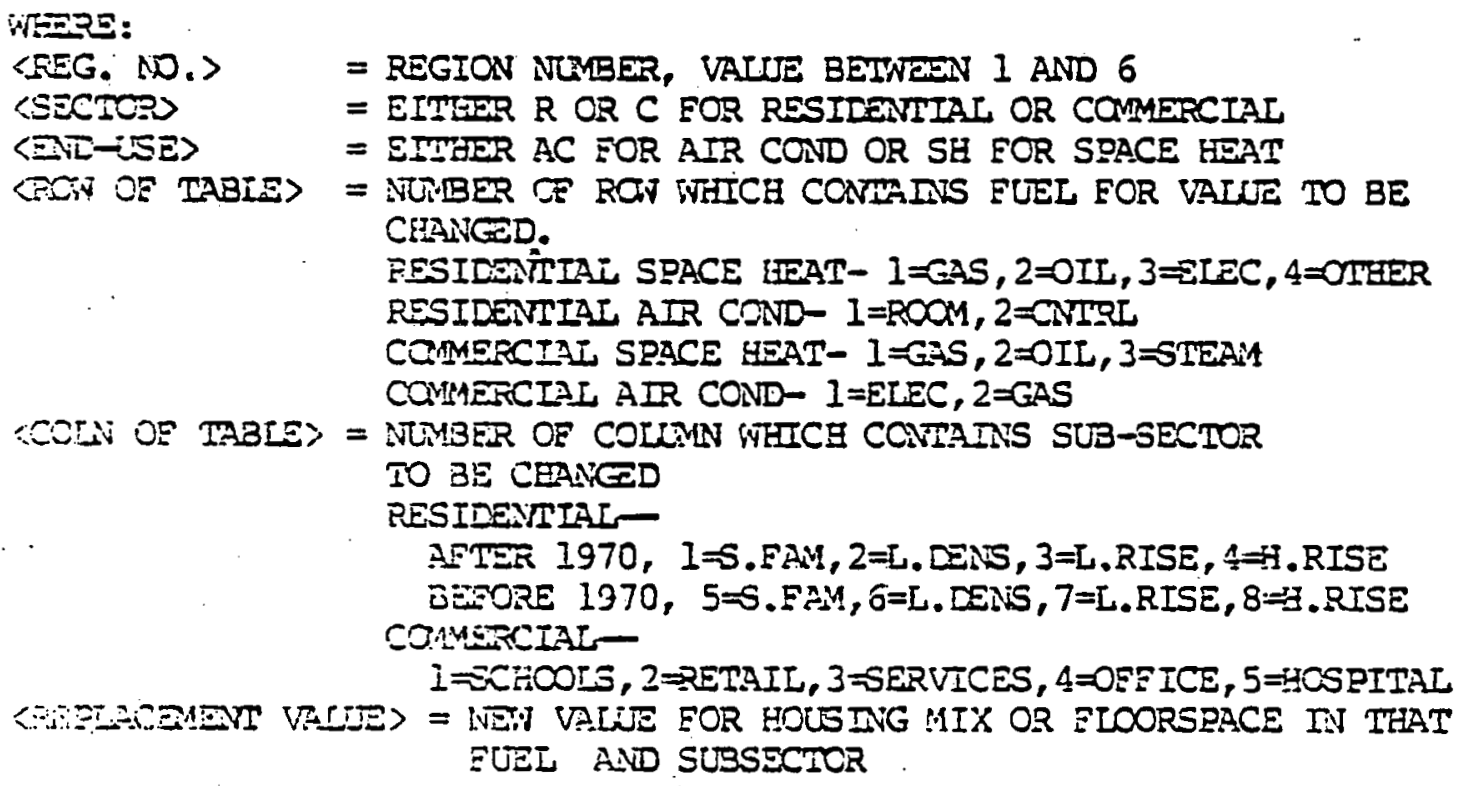

NTE CHARE SEQUEDE:

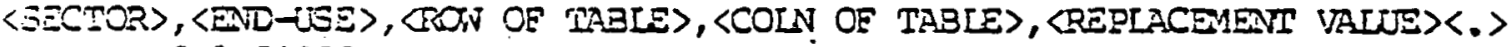
(10) $\rightarrow \tau, a, 2,1,500002$

Ferial hust be Tyres at End of Change Sequence.

TUEE 2 TO DISPIAY TISTRLCTIONS ON HON TO CEANE THE VARIABLSS ABOVE

I TO ENIER CEAVE SEQJENCE ON FLCORSFACE OR HCUSLIG MIX

(ii) $\rightarrow i$

O TO CONTARE ERCERAM

DATE CHANG SETENCE:

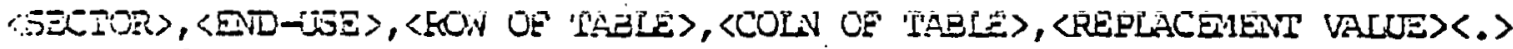

$\rightarrow \tau, 3: 2,8,900000$.

TRE - TO DISPISY INSTRUCTIONS DN EON TO CHANE THE VARIABLES ASOVE

1 TO ENTE CHANG SEQUEXC CN ELCORSPACE OR HOUSTNG MIIX

O TO COLIRTE PACGAM

$\rightarrow 0$ 
THE MODIFIED HOUSTNG MIX \&/OR ELOORSPACE FOR THE REGION(S)

AND THE END USE (S) CHANGIED ABCVE

ALL OTHER REGIONS AND END USES HAVE THE ShHE HOUSING MIX E/OR FLOORSINCE LISTED ABOVE

SPACE HEAT HOUSING MIZ, REGION 6 (NO. DF HOUSEHOLDS)

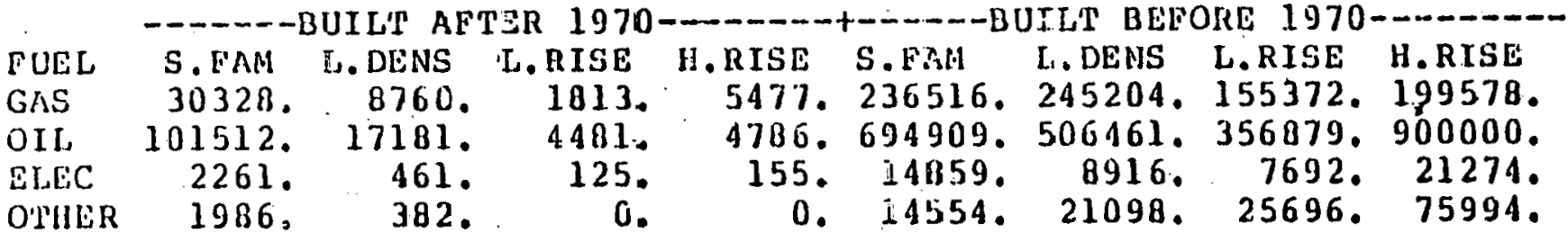

AIR CONDITIONENG HOUSING MIK, REGION 6 (NO. OE AIR COND UNITS)

- - - BUILT AFTER 1971)-- - -

FUEL S.FAM L.DENS L.RISE H.RISE S.FAM L.DENS L.RISE H.RISE

ROOM 171324. 0.0 .007505 .424575 .276344 .711996$.

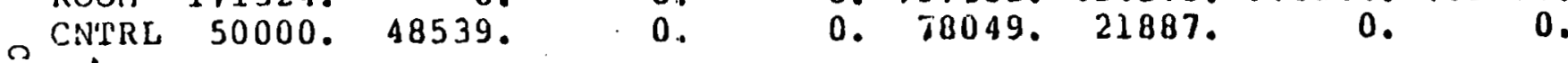

$\$$ TYPE THE CHANGE IN THE NUMBER OF HEATING DEGREE DAYS FOR REgION 6

(13) $\rightarrow$ YEAR 1978

TYPE THE CHANGE IN THE NUMBER OF COOLING DEGREE DAYS FOR REGION 6

(11.) IN YEAR 1978

$\operatorname{lin}_{\rightarrow 100}$ 


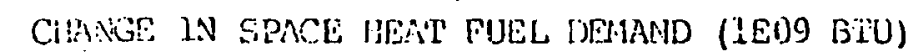

\begin{tabular}{|c|c|c|c|c|c|c|c|c|c|c|c|}
\hline \multirow[b]{2}{*}{$\begin{array}{c}\text { FEG } \\
6\end{array}$} & \multirow[b]{2}{*}{$\begin{array}{l}\text { G.9 } \\
860.6\end{array}$} & \multirow[b]{2}{*}{ OCI, } & \multirow[b]{2}{*}{$\begin{array}{l}\text { ELERC } \\
38.4\end{array}$} & \multirow[b]{2}{*}{$\begin{array}{l}\text { OIHRR } \\
223.7\end{array}$} & \multicolumn{3}{|c|}{ CAMERCIAL, } & \multicolumn{2}{|c|}{ 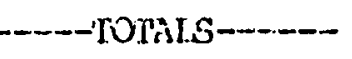 } & \multicolumn{2}{|c|}{ - } \\
\hline & & & & & $\begin{array}{l}\text { O.L } \\
49.11 .3\end{array}$ & $\begin{array}{l}G .5 \\
466.0\end{array}$ & $\begin{array}{l}\text { SPIBAM } \\
626.5\end{array}$ & $\begin{array}{l}\text { OIL } \\
7537.2\end{array}$ & $\begin{array}{l}\text { GAS } \\
1326.6\end{array}$ & $\begin{array}{l}\text { RESID } \\
3748.7\end{array}$ & $\begin{array}{l}\text { COMLIL } \\
6003.8\end{array}$ \\
\hline 'TOl' & 8600.6 & 2625.3 & 30.4 & 223.7 & 1911.3 & 466.0 & 626.5 & 7537.2 & 1326.6 & 3748.7 & 6003.8 \\
\hline
\end{tabular}

CHUNG IN AIR CONCTTIONING RUEL DEMAND (1E0!) B'I'(I)

\begin{tabular}{|c|c|c|c|c|c|c|c|c|}
\hline \multirow{3}{*}{$\begin{array}{c}\mathrm{KEG} \\
6\end{array}$} & \multicolumn{2}{|c|}{--IRES IDENCIAL-- } & \multicolumn{2}{|c|}{--COMMERCIAL-- } & \multicolumn{2}{|c|}{ - - - JOTAI,_-_- } & \multicolumn{2}{|c|}{-'IOPAL_- } \\
\hline & $i 20 \times$ & COMLL & ELEC & GAS & ELEC & GAS & RESID & COMML \\
\hline & 919.7 & 137.7 & 609.8 & 29.7 & 1667.2 & 29.4 & 1057.4 & 639.2 \\
\hline TOY & 919.7 & 137.7 & 609.8 & 29.4 & 1667.2 & 29.4 & 1057.4 & 639.2 \\
\hline
\end{tabular}

TO RERUN THE PROGFAM, STARTING WITH THE SAME HOUSING

(15) $\rightarrow x$

\section{IN REGION 6 LISTED ABOVE, TYPE R.}

TYYE $N$.

i

OUTPUT CE THE RESIDENIIAL HOUSING MIX AND COMMERCIAL FIOORSPACE

CAIT BE SUPPRESSED. CALCULATION OF CHANGE IN EUEL DEMAND FOR BOTH

SEC NUPS NILL BE DONE, AND DISPLAYED.

TYPE R TO SEE ONLY RESIDENTIAL HOUSING STOCK
C TO SEE ONLY COMMERCIAL ELOORSPACE
G TO SEE BOIH FLCORSPACE AND HCUSING STOCK
N TO SUPPRESS ALT, OUPPUT

(6) $\rightarrow n$

AD ELDORSPACE OR HOUSING STOCK WILL BE SHOWN

TYPE THE REGION NIMBER (1-6) TO LIST THE COUNIIES IN A REGION

OR 0 TO CONIINUE PROGRAM

$\rightarrow 0$ 
Sarole vieatior Model Qutout - Page 8.

TYYPE R TO CEANEE RESIDENTILI FUEL EFEICIEIXIES

$C$ TO CHANE COMMERIAL EUEL EFFICIENCIES

D TO DISPLAY FUEL EFEICIENCIES USED IN PROGRAM

(17) $\rightarrow x$

$X$ TO CONTINUE PROGRAM

\begin{tabular}{|c|c|c|c|c|c|}
\hline Est & SNILA & & ICLE & Its & \\
\hline SPACE & HEAT & & AIR & DNDITI & NING \\
\hline $\begin{array}{c}\cos s \\
1\end{array}$ & & $\begin{array}{c}\text { EFE } \\
.75\end{array}$ & $\begin{array}{c}\text { CODE } \\
5\end{array}$ & $\begin{array}{l}\text { EUEL } \\
\text { ROOM }\end{array}$ & $\begin{array}{l}\text { EFE } \\
3.00\end{array}$ \\
\hline $\begin{array}{l}3 \\
4\end{array}$ & $\begin{array}{l}\text { ELEC } \\
\text { OTHER }\end{array}$ & $\begin{array}{r}1.00 \\
.35\end{array}$ & 6 & Covisu & SU \\
\hline
\end{tabular}

COMNEFCIAL EUEL EFEICIENXIES

SPACE FEAT AIR CONDITIONING

CODE FUEL EEF COEE PUEL EET

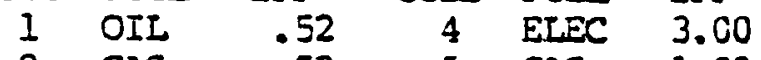

2 GAS $.52 \quad 5$ GAS 1.80

3 STENi . .65

TYEE 2 TO DISPAY INSTRLCTIONS ON EOH TO CHANG THE VARIABLES ABOVE

1 TO ENTER CEDNE SECUENCE ON ELOORSPACE OR HOUSTIG MIX

(iB) $\rightarrow 1$

O TO COMTIUE IRCORAY

DIEP CEAHE SEDENC:

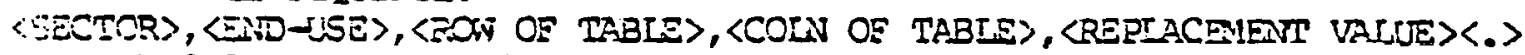

(i) $\rightarrow 1,3 \mathrm{i}, 2,1,90000$.

TPE 2 TO DISEIY INSTRCTIONS ON MGN TO CHANGE THE VARIABIES ABOVE

1 TO ENTER CBPYGE SEOUENCE ON FLCORSPACE OR HOUSING MIX

$\rightarrow 0$

0 TO CONTAIJJ PRCGAH 
THE MODIFIED HOUSING MIX \&/OR FLOORSPACE FOR THE REGION(O)

AND THE END USE (S: CHANGED ABOVE

ALL CITHER REGIONS AND END USES HAVE THE SAME HOUSING MIX \&/OR FLOORSPACE LISTED ABOVE

SPACE HEAT HOUSING MIX, REGION 6 (NO. OF HOUSEHOLDS)

\begin{tabular}{|c|c|c|c|c|c|c|c|c|}
\hline PUEL & S. PANA & L. DXNS & L.RISE & II.RISE & S.FAM & L.. DABNS & L..RISE & H. RISE \\
\hline$i^{2}$ & 30324. & U7:0. & 1813. & 5477. & 236516 & 245204 & 155372 & 199578. \\
\hline II & 90000. & 17161. & 4481. & 4786. & 694909. & 506461. & 356879 & 900000 \\
\hline LEC & 2261 . & AEl. & 125. & ].55. & 14859. & 89.16. & 7692. & 2.1274 \\
\hline DTUER & 1986. & 382. & $n$ & 0 & 14 & 210983. & 25696. & 75994. \\
\hline
\end{tabular}

IYYEE THE CHANGE IN THE NIMBER OF HEATING DEGREE DAYS FOR REGION 0

IN YEAR 1978

(20) $\rightarrow 1000$

TYPE THE CHANGE IN THE NUMBER OF COOLING DEGLEE DAYS FOR REGION -

IN YI:AR 1978

(21) $\rightarrow 1000$

$\stackrel{?}{1}$

CHANGE IN SPACE HPAT FULL DEMAND (1E09 B'TU)

REG -_-

OIL ELEC OTHR OII

COMERCIAL

GAS

STEAM
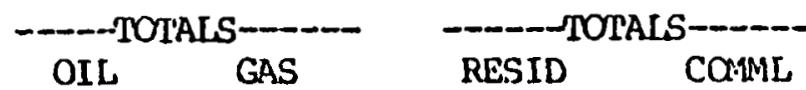

$\begin{array}{llllllll}6 & 8606.1 & 26025.6 & 384.4 & 2237.2 & 49113.1 & 4659.9 & 6265.2\end{array}$

$75138.7 \quad 13266.0$

$37253.3 \quad 60038.2$

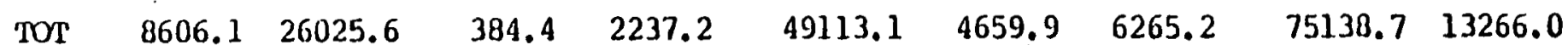

$37253.3 \quad 60038,2$

CHANGE IN AIR CONDTTIONING FUEL DEMAND (1E09 BTU)

\begin{tabular}{|c|c|c|c|c|c|c|c|c|}
\hline \multirow{3}{*}{$\begin{array}{c}\text { REG } \\
6\end{array}$} & \multicolumn{2}{|c|}{--RES IDENIIAL--- } & \multicolumn{2}{|c|}{-COMMERCIAL- } & \multicolumn{2}{|c|}{ - } & \multicolumn{2}{|c|}{ - - TORAL- } \\
\hline & ROOM & COMML. & ELEC & GAS & ELEC & GAS & RESID & COMML \\
\hline & 9197.3 & 1377. & 6098.2 & 294 & 16672.5 & 294 & 10574.3 & .5 \\
\hline & 9197.3 & 1377. & 6098.2 & 294. & 16672.5 & 294.3 & 10574.3 & 6392.5 \\
\hline
\end{tabular}

TO RERUN THE PROGRAM, STARTING WI'I'H THE SAME HOUSING

MIX IN REGION 6 LISTRED ABOVE, TITE R.

$22, \rightarrow n$

TO END THE PROGRIM, TYEE N.

END WEATHER

.564 CP SECOHLS EXECITISAI TIME 
Sample ioather Hodel Output with User Errors - Rage 1.

TYPE TIE TARGET YEAR AS XXXX

$\rightarrow 1986$

User typed target year larger than 1985

(1)

YOU MADE A MISTAKE! TRY AGAIN-

TYPE THE TARGET YEAR AS XXXX

$\rightarrow 1985$

CUTFUT OF THE RESIDENIIAL HOUSING MIX AND COMMERCIAL FIOORSPACE

CAN SE SUPPRESSED. CAICULATION OF CHANGE IN FUEL DEMAND FOR BOTH

SECTORS WIIL BE DONE, AND DISPLAYED.

TYEE $R$ TO SEE CNLY RESILENTIAL EOUS ING STOCR

C TO SEE ONLY COMERCIAL ELOORSPACE

8 TO SEE BOTE ELOCRSEACE AND BOUSING STOCK

N TO SUPFRESS ALI OUIPUT

(2) $\rightarrow 0$

User tyoed the output suppression command incorrectly.

YOU MAIE A MISTAKe! TRY ÁGA-

OUTPUT OE THE RESICENTIAL ROUSTVG MIX AND COMMERCIAL FLOORSPACE

CAII BE SUPPRESSED. CAICULATION OF CHANGE IN FUEL DEMAND FOR BOTE

SECTORS WILI BE DONE, ALND DISPLAYED.

-TIFE R TO SEE ONLY RESIDENTIAL EOUSING STOCR

C TO SEE ONLY COMARCIAL FLOORSPACE

B TO SEE BOTH FLOCRSPACE AND HCLSING STOCK

N TO SUPREESS ALL OUTPUT

$\rightarrow n$

DO FLOORSPACE OR HCUS ATG STCK WILL BE SHOWN

TYPE THE REGICN NUYBER (1-6) TO LIST THE COUNTIES IN A REGION

OR . O TO CONIINUE PRCORAH.

$\rightarrow \mathrm{x}$

User typed a letter for the region number.

$x<$ ERROR, RETYEE RECORD AT THIS FIELDQ) User correction

TIPE R TO CEANE RESIDENTIAL FUEL EFFICIENCIES

$C$ TO CHANE COMERCIAL EUEL EFFICIENCIES

$D$ TO DISPLA FUEL EEFICIENCIES USED IN PROGRAM

$X$ TO COVIISTE PROERAM

(4) $\rightarrow z$ User typed an incorrect efficiency change command

YOU MACE A MISIRKE! TRY ACAIN-

TVEE $R$ TO CHALE RESIDENTIAL FUEL ERFICIENCIES

C TO CHANE COMERCIAL EUEL EFFICIENCIES

D TO DISPLAY EUEL EEFICIENCIES USED IN PROGRAM

$X$ IO CONLIIUE PROGRAM

$\rightarrow x$ 
ITPE 2 TO DISFLAY INSTRUCTIONS ON BON TO CHANGE THE VARIABLES ABOVE

1 TO ENTER CHANEE SEQUEDCE ON FLOORSPACE OR HOUSING MIX

0 TO CONTINUE PROGRAM

$\rightarrow 1$

ENTER CHANGE SEQUENCE:

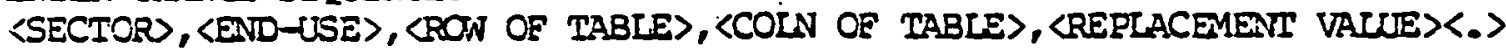

$\rightarrow r, s s h, 2,8,900000 . K$ (1) User typed an incorrect end-use - "ssh".

R,SSE, < ERROR, RETYPE RECORD AT TEIS FIELD 2,8,900000. 万

(2) User retypes line, starting with the information following

YOU MADE A MISTAKE! TRY AGAINthe incorrect data.

\section{- (3) proaran displays error message}

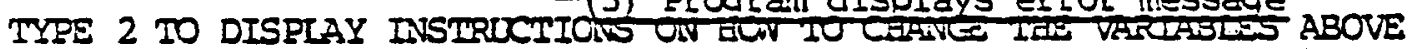

I TO ENIER CEANEC SEQUENCE ON FLOORSPACE OR EOUSING MIX

O TO CONTINUE PROGRAM $\rightarrow 1$

FINTSR CGANGE SEGJENCE:<smiles></smiles>

(4) User re-enters the entire original line.

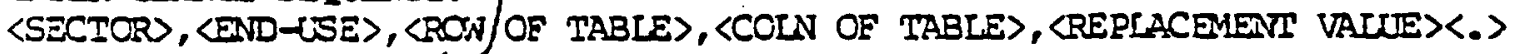

$\rightarrow r, \operatorname{sh}, 2,8,900000$.

ITPE 2 TO DISPLAY IIISTRUCTIONS ON HON TO CEANGE THE VARIABLES ABOVE

1 TO ENIER CEALIE SEQUENCE ON FLOORSPACE OR HOUSING MIX

$\rightarrow 1$

0 TO CONTINUE PROERAM

ETER CEANGE SEGUECE:

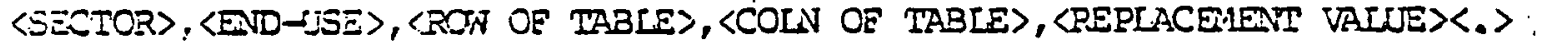

$\rightarrow r, a d, 1,1,160000$. (I) User typed an incorrect end-use - "ad"

YOU ITLEE A MISTRKE! TRY AGAIN-

TYPE 2 TO DISFLAY IISTRLCTIONS ON HAN TO CHANGE THE VARIABLES ABOVE

I TO ENIER CENANE SEQUENCE ON FLOORSPACE OR HCUSING MIX

0 TO CONIINUE PRCGEAM

$\rightarrow 1$

- tanter cERNE SEgERTE:

(2) User retyces entire original line

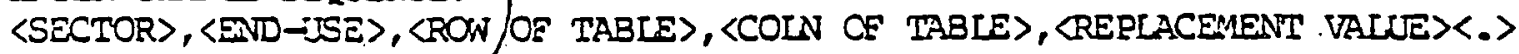

$\rightarrow$ r, ac, I, I, 160000.

TYPE 2 TO DISFIAY INSTRUCTIONS ON HON TO CHANE THE VARIABIES ABOVE

I TO ENIER CFANGE SEQTIXE ON FLOORSPACE OR HOUSING MIX

O TO CONTINE PROGRAM

$\rightarrow 0$ 
screen, 132

COMMAND- Eij, j00

COMAMND- attach, price, id=nyseo, mr=l.

PEN IS

FRICE

PF CYCLE NO: $=001$

COMMAND- grice.

WELCOME TO TEE SEORT TERM PRICE ELASTICITY MODEL OR THE NEW YORK STATE ENERGY INEORMATION SYSTEM

$1=R E S I D E N T I A L-C O M M E R C I A L$ WEICE SECTOR DO YOU WANT (I OR 2 ) $\gg 2$

$2=I N D U S T R I A L$

TEESE ARE TEE ELASTICITIES FOR INDUSTRIAL

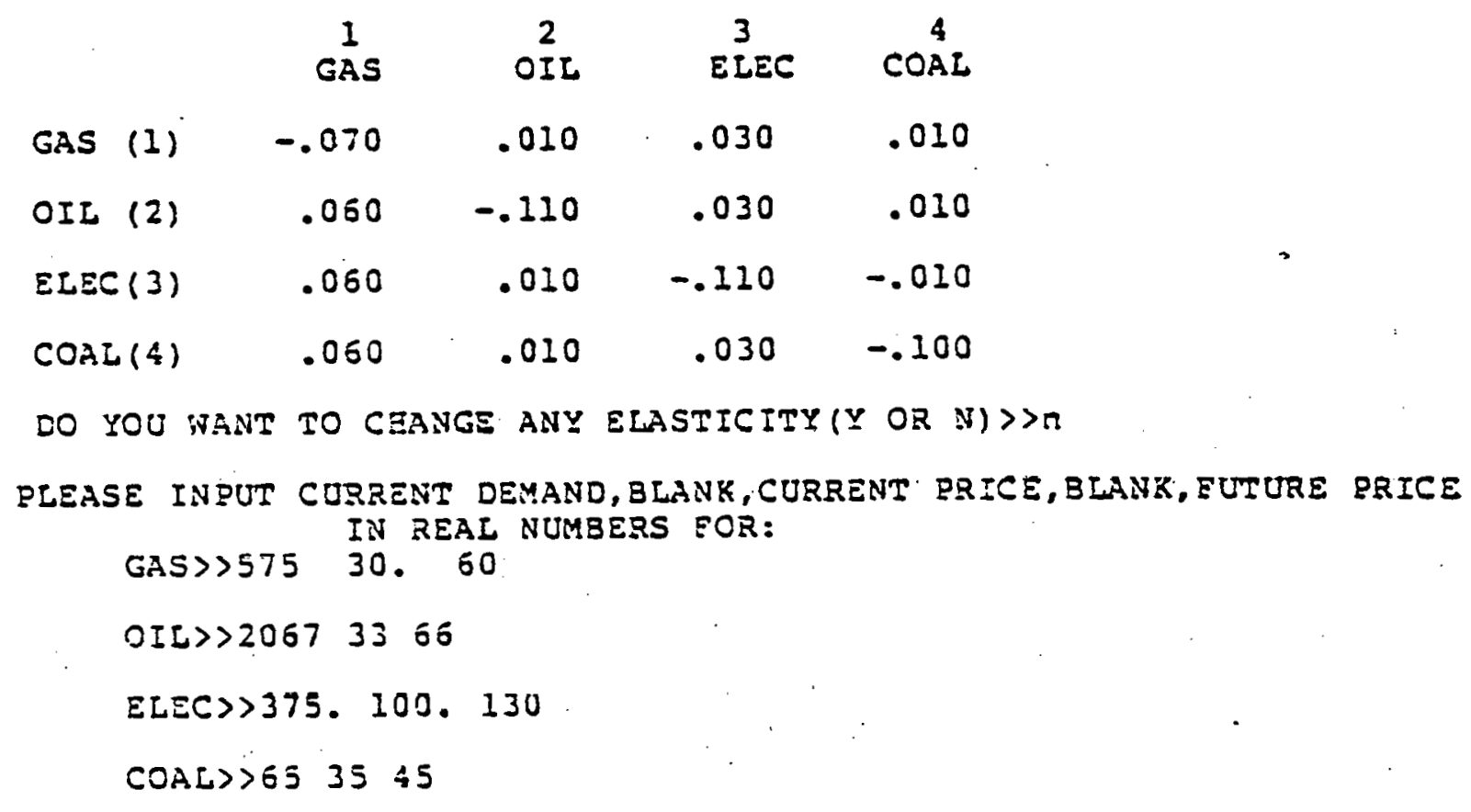

\footnotetext{
PRESENT

DEMAND

575.00

EUEL

GAS

OIL

ELEC

COAL

2067.00

375.00

65.00

33.000000

100.0000000

35.0000000

DEMAND

547.32

1938.16

387.80

68.28

E OTURE

PRICE 60.0000000 66.0000000 130.0000000 45.0000000

WOULD YCU LIKE TO RUN THE MODEL AGAIN (Y OR N) $\gg n$

STC?

.0S2 CP SECONDS EXECUTION TIME
}

COMAAND- 


\section{Short Term Price Elasticity Model}

The Short Term Price Elasticity Model described fully in Chapter 2, contains elasticities for two sectors and four fuels, The elasticity $E_{i j k}$ denotes the electricity of demand of fuel " $j$ " with respect to the price of fuel " $k$ " in sector " $i$ ". The user selects one of the two sectors and then inșerts, for each of the four fuels " $\mathrm{j}$ ", the following information:
1) Current demand: $d_{i j}^{c}$
2) Current price: $p_{j}^{c}$
3) Future price: $p_{j}^{f}$

The program then returns the future demands: " $d_{i f}^{i}$ " for the four fuels for which elasticities are designated. The equation used to compute future demand for fuel " $\mathrm{f}$ " in sector " $i$ " is:

$$
d_{i j}^{f}=\left[1+\sum_{k=1}^{4} \frac{\left(P k^{f}-P k^{c}\right)}{P k^{c}}=E_{i j k}\right] d_{i j}^{c}
$$

A sample run of the program is shown below. 